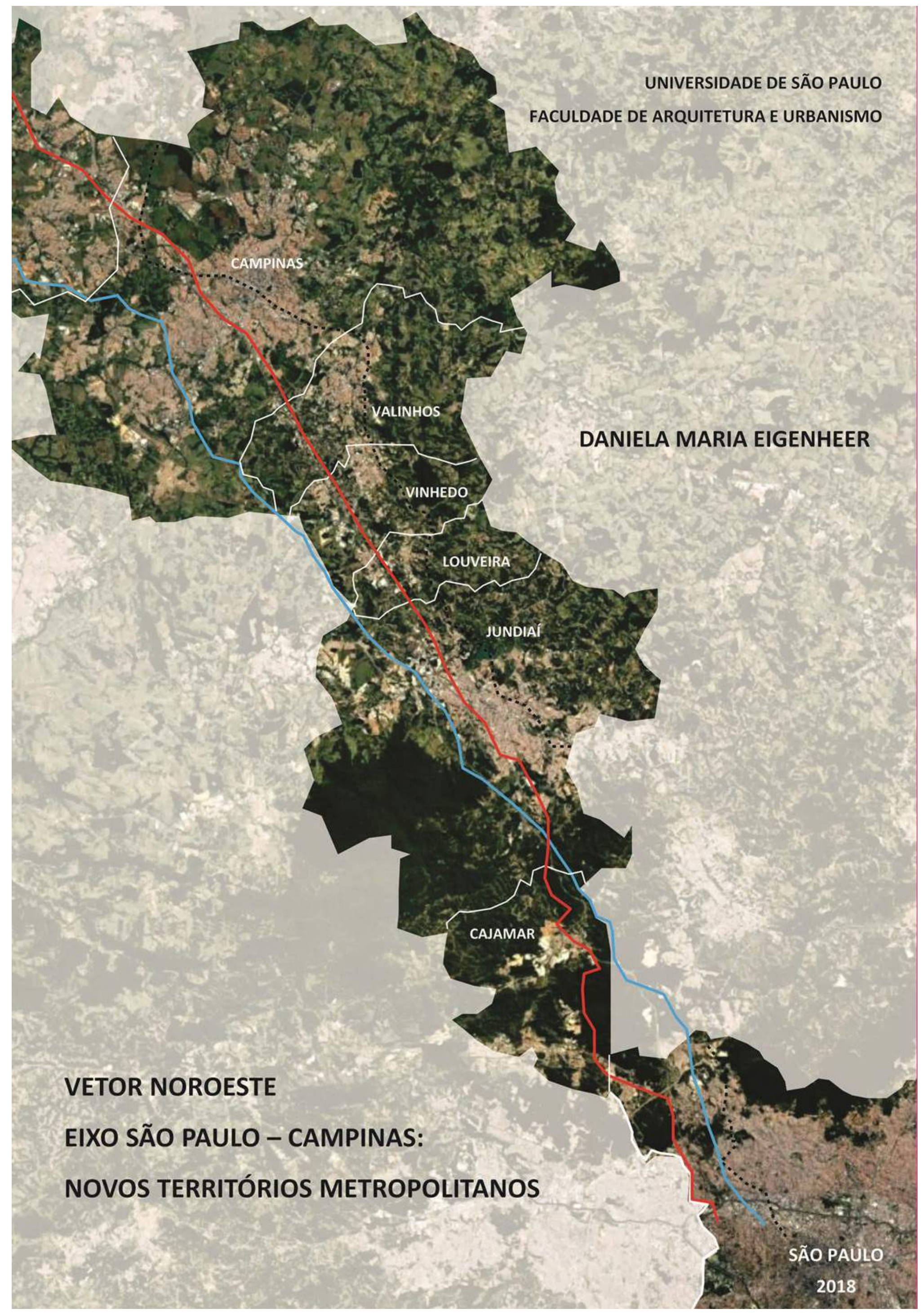


UNIVERSIDADE DE SÃO PAULO

FACULDADE DE ARQUITETURA E URBANISMO

DANIELA MARIA EIGENHEER

\section{Vetor Noroeste Eixo São Paulo - Campinas: \\ Novos Territórios Metropolitanos.}

Tese apresentada à Faculdade de Arquitetura e Urbanismo da Universidade de São Paulo para a obtenção do título de Doutora em Arquitetura e Urbanismo.

Área de Concentração: História e Fundamentos da Arquitetura e Urbanismo.

ORIENTADOR:

Prof. Dr. Nestor Goulart Reis.

CO-ORIENTADORA:

Prof. ${ }^{a}$ Dr. ${ }^{a}$ Nadia Somekh.

\section{São Paulo}


Autorizo a reprodução e divulgação total ou parcial deste trabalho, por qualquer meio convencional ou eletroinico, para fins de estudo e pesquisa, desde que citada a fonte.

Catalogação na Publicação

Servipo Técnico de Biblioteca

Faculdade de Arquitetura e Urbanismo da Universidade de São Paulo

Eigenheer, Daniela Maria

Vetor Noroeste Elixo São Paulo - Campinaas: Novon TerritGrios Metropolitanos. / Daniela Maria Bigenheer, orientador Nestor Goulart Reis. coorientador Nadia Somekh - São Paulo, 2018. $129 \mathrm{P}$.

Tese (Doutorado) - Faculdade de Arquitetura e Urbanismo da Universidade de Sso Paulo. Krea de concentraç̋̄o: História e Pundamentos da Arquitetura e do Urbanismo

1. Diapersฐ̄o Urbana. 2. Territórios

Metropolitanos. 3. Projetos Urbanos. 4. Planejamento Regional. 5. Urbanismo. I. Reis, Nestor Goulart, orfent. II. Titulo. 
Nome: Daniela Maria Eigenheer.

Título: Vetor Noroeste Eixo São Paulo - Campinas: Novos Territórios Metropolitanos.

Tese apresentada à Faculdade de Arquitetura e Urbanismo da Universidade de São Paulo para a obtenção do título de Doutora em Arquitetura e Urbanismo.

Aprovado em:

..$/ \ldots$

Banca Examinadora

Prof. Dr. Nestor Goulart Reis Filho.

Instituição: FAU- USP

Julgamento:

Profa. Dr/a.

Instituição:

Julgamento:

Prof.Dr/a.

Instituição:

Julgamento:

Prof.Dr/a.

Instituição:

Julgamento:

Prof.Dr/a.

Instituição:

Julgamento: 


\section{AGRADECIMENTOS}

Essa pesquisa é resultado de quatro anos de investigação sob orientação do professor Doutor Nestor Goulart Reis Filho e co-orientação da professora Doutora Nadia Somekh, respeitáveis mestres com quem tive o privilégio de conviver e aprender durante a elaboração dessa tese, e aos quais quero especialmente agradecer pelo grande espírito científico e por me proporcionarem reflexões fundamentais para realização desta pesquisa.

Ao meu orientador, professor Dr.Nestor Goulart Reis Filho, agradeço pela sua minuciosa capacidade de apreensão de detalhes e pela grande contribuição teórica que norteou toda esta pesquisa.

A minha co-orientadora, professora Dra. Nadia Somekh, agradeço pela motivação, insights, oportunidades e críticas que sempre me fizeram avançar e descobrir novos caminhos.

Aos professores, Eduardo Nobre e Sueli Schiffer, pelas valiosas contribuições na banca de qualificação.

Às professoras Regina Meyer e Roberta Fontan pela disponibilização de imagem cedida pelo LUME- Laboratório de urbanismo da metrópole.

A Capes e a FAU-USP pela concessão de uma bolsa de estudos dentro do Programa de Doutorado Sanduíche no Exterior PDSE-2016, realizado em 2017, na Universidade Politécnica de Milão, permitindo-me um novo olhar à minha pesquisa.

Ao Dastu, Departamento de Arquitetura e Estudos Urbanos da Universidade Politécnica de Milão; Antonella Contin, Pedro Ortiz e Narges, pela oportunidade de aprimoramento e troca de conhecimento internacional.

Às prefeituras de Valinhos, Vinhedo, Louveira e Cajamar pelo suporte na busca de dados e imagens aéreas. Às empresas, SSR Tecnologia, Multispectral e Geojá, pela disponibilização de imagens áreas para o embasamento empírico desta tese.

Ao atual secretário da educação da Prefeitura Municipal de Guarulhos, Alexandre Zeitune, pela concessão de uma LIP- licença prévia, para que eu pudesse me ausentar para realizar uma etapa da minha pesquisa na Universidade de Milão. Ao meu ex-diretor Fernando Sapun e a arquiteta Adriana Fuga, pela flexibilização da minha jornada de trabalho.

A minha família pelo apoio.

A alguém especial e maior, obrigada pela sua luz. 


\section{RESUMO}

A partir do novo século, dinâmicas de dispersão urbana diferenciadas, relacionadas com os avanços da econômica capitalista, alteram os padrões de ocupação do tecido urbano ao longo do vetor noroeste paulista, eixo São Paulo-Campinas. Esse histórico e produtivo corredor, cuja evolução se estrutura em redes de infraestruturas e sobrepõe temporalidades históricas fragmentadas, transformou-se no mais importante vetor econômico do país. Tempos de globalização e reestruturação produtiva avançada configuram novos territórios metropolitanos, que na sua dispersão se integram, redefinindo conceitos e limites instituídos. Com olhar empírico para municípios com formação recente e predomínio de ocupações ligadas à economia moderna, evidenciou-se o impacto destas no tecido urbano deste eixo regional. Formas mais avançadas de urbanização em processo de constituição, extensas, fragmentadas, superpostas, contínuas, dispersas e porosas, apresentam contornos mais nítidos, mas são complexas do ponto de vista dos seus fluxos espaciais. Devido à ausência de planos e políticas públicas mais abrangentes capazes de atuar em novas dimensões, compreendendo a totalidade das relações que este território metropolitano estabelece, elabora-se uma matriz que sistematiza hierarquias e conhecimento, para uma atuação territorial integradora e em múltipla escala.

Palavras chaves: Território, Dispersão, Infraestrutura, Continuidade e Fragmentação.

\section{ABSTRACT}

From the new century, new dynamics of urban sprawl, related to the progress of the capitalist economy, are changing the land use patterns along the northwest vector of São Paulo state capital, São Paulo -Campinas axis. This historical and productive axis, whose evolution is structured in infrastructure networks and overlaps fragmented historical temporalities, has become the most important economic vector of the country. Times of globalization and advanced productive restructuring have shaped new metropolitan territories which, in their sprawl are integrated, redefining concepts and set limits. With focus on small cities, due to their recent formation, the research observed the impact of the greater intensity of tertiary sector occupations linked to the advanced economies in this regional productive axis. More advanced forms of urbanization in the process of constitution, extensive, fragmented, overlapping, continuous, sprawl or diffuse, have more visible boundaries, but are complex from the point of view of their spatial relationships. Based on this and due to the lack of metropolitan and regional public policies that may have a comprehensive and integrated impact on this scattered metropolitan territory, a matrix is elaborated that systematizes hierarchies and knowledge, for an integrative and multiple scale territorial action

Keywords:: Territory, Sprawl, Infrastructure, Continuity and Fragmentation. 


\section{SUMÁRIO}

Resumo/Abstract

INTRODUÇÃO.

CAPÍTULO 1 - Teoria: Modernizações Capitalistas e Urbanização Avançada......

1.1. Produção do Espaço Capitalista: Tecnologia, Infraestrutura e Dispersão Urbana...........12

1.2. Reestruturação Produtiva Avançada e Novas Dinâmicas de Dispersão Urbana.............21

CAPÍTULO 2 - Evolução Espacial: Das Vilas aos Novos Territórios Metropolitanos.......31

2.1. Temporalidades Históricas: Vetor Noroeste: Eixo São Paulo - Campinas....................32

2.2. Industrialização e a Formação da "Grande São Paulo" ...........................................36

2.3. Desconcentração Industrial e Áreas Metropolitanas...........................................38

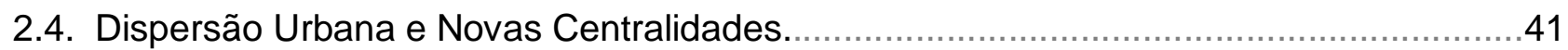

2.5. Dispersão dos Serviços e Novos Territórios Metropolitanos...................................45

CAPÍTULO 3 - Escala Local: Integração e Segregação em Territórios Metropolitanos ...50

3.1. Continuidade Territorial e um Novo Arranjo Metropolitano......................................51

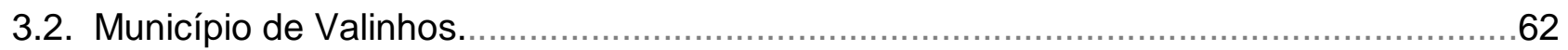

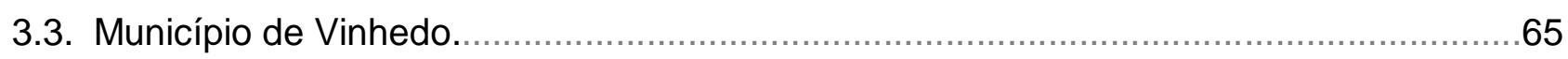

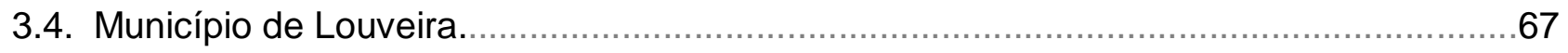

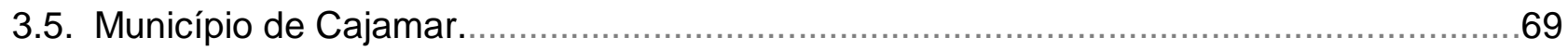

CAPÍTULO 4 - Escala Regional: Integração e Fragmentação do Espaço Nacional..........85

4.1. Alteração dos Fluxos da Economia Paulista e Novos Arranjos Espaciais.......................86

4.2. Eixos Viários Produtivos de Integração e Fragmentação Espacial..............................98

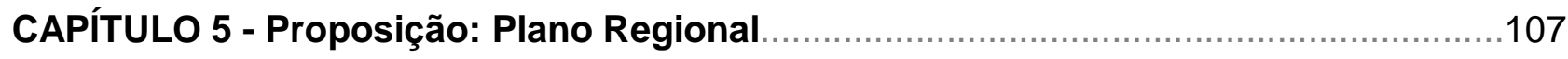

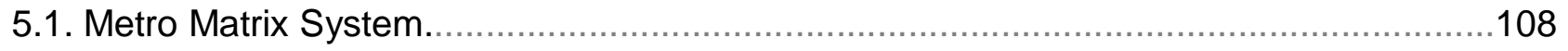

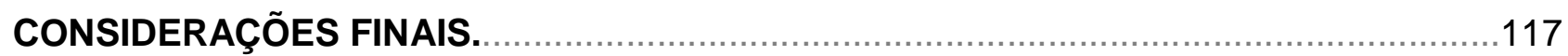

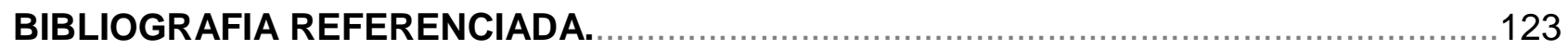

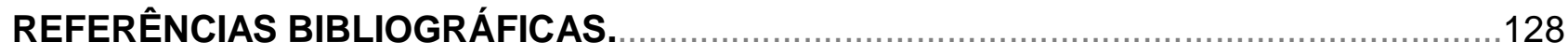




\section{LISTA DE ILUSTRAÇÕES}

\section{INTRODUÇÃO}

Figura 1.1 Eixo Anhanguera e o vetor Noroeste, inserção nacional, estadual e metropolitana.

\section{CAPÍTULO II}

Figura 2.1 Eixos Estruturadores do quadro econômico e urbano do território paulista.

Figura 2.2 Centro Empresarial Campinas, Centro Tecnológico Mazak Vinhedo; Shopping Iguatemi Jundiaí

Figura 2.3 Limites administrativos dos municípios localizados no eixo Anhanguera.

Figura 2.4 Vetor Noroeste inserção a macrometrópole Paulista.

\section{CAPÍTULO III}

Figura 3.0 Mancha urbana e principais eixos que atravessam municípios do vetor noroeste paulista.

Figura 3.1 LINHA FÉRREA, em um trecho de Vinhedo, Louveira e Valinhos.

Figura 3.2 ESTRADA DA BOIADA Valinhos, Vinhedo, Louveira. Ciclovia, tráfego, comércio e condomínios.

Figura 3.3 Avenida seguindo a linha férrea. Fruticultura estrada Boiada. Áreas rurais entre condomínios.

Figura 3.4 Áreas industriais adjacentes a Anhanguera: Vinhedo km 75; Louveira km 71; Cajamar- Km 36.

Figura 3.5 Evolução Mancha Urbana Vetor Noroeste 1975-2010.

Figura 3.6 Distribuição dos aglomerados subnormais no país com concentração no vetor noroeste.

Figura 3.7 1 Vinícola Louveira; 2 Indústria Anhanguera; 3 Condomínio Valinhos; 4 Serviços Vinhedo

Figura 3.8 Imagem aérea parcial 2008 - Município de Valinhos.

Figura 3.9 Google Earth 2005: Trecho Anel Viário e Condomínios.

Figura 3.10 Emplasageo 2018 - Trecho Anel Viário, abertura novos cond. e adensamento construtivo.

Figura 3.11 Ortofoto 2008 - Condomínio Residencial.

Figura 3.12 Emplasageo 2018 - Adensamento condomínio residencial.

Figura 3.13 Imagem Google Earth 2005.

Figura 3.14 Emplasageo 2018: Shopping Valinhos, Blue Tree, Torres de Escritórios e Cond. Residenciais.

Figura 3.15 Imagem Google Earth 2005.

Figura 3.16 Emplasageo 2018: Adensamento e novas instalações Condomínio Industrial.

Figura 3.17 Imagem aérea 2006 - Município de Vinhedo.

Figura 3.18 Ortofoto 2006: Eixo Estrada da Boiada.

Figura 3.19 Emplasageo 2018: Estrada da Boiada: condomínios, adensamento e setor terciário.

Figura 3.20 Ortofoto 2006:Área Rural.

Figura 3.21 Emplasageo2018 -Condomínio Fechado Campos de Toscana.

Figura 3.22 Ortofoto 2006: Condomínio Residencial

Figura 3.23 Emplasageo2018 - Adensamento Cond. Residencial.

Figura 3.24 Ortofoto 2006: Área residencial condomínios fechados.

Figura 3.25 Emplasageo 2018: Adensamento em cond. fechados existentes e novos loteamentos.

Figura 3.26 Ortofoto2006 Área periférica - bairro popular

Figura 3.27 Emplasageo2018: Área periférica e novos loteamentos alta renda

Figura 3.28 Ortofoto 2006: Área central.

Figura 3.29 Emplasageo 2018: Área central, novas ocupações e alargamento viário.

Figura 3.30 Readequação paisagística e ampliação e duplicação sistema viário principal. 
Figura 3.31 Ortofoto2006 Distrito Industrial.

Figura 3.32 Emplasageo2018 Distrito Industrial - novas ocupações, indústrias modernas.

Figura 3.33 Imagem aérea 2010 - Município de Louveira

Figura 3.34 Google Earth 2008 : Condomínios Residenciais

Figura 3.35 Emplasageo2018: Novos loteamentos e adensamento.

Figura 3.36 Ortofoto 2010 : Condomínio residencial periférico.

Figura 3.37 Emplasageo 2018: Adensamento condomínio.

Figura 3.38 Google Earth 2008: Eixo Anhanguera.

Figura 3.39 Google Earth2017: Eixo Anhanguera e novas indústrias.

Figura 3.40 Imagem aérea 2001 - Município de Cajamar.

Figura 3.41 Ortofoto 2001: Área às margens da Via Anhanguera.

Figura 3.42 Google Earth 2017: Condomínios Logísticos às margens da Via Anhanguera.

Figura 3.43 Ortofoto 2001: Área central.

Figura 3.44 Emplasageo 2018: Expansão centro, novos loteamentos e condomínios logísticos.

Figura 3.45 Desenvolvimento urbano ao longo de eixos históricos: Cajamar, Louveira, Valinhos e Vinhedo.

\section{CAPÍTULO IV}

Figura 4.1: Intensidade e distribuição e intensidade dos fluxos para trabalho e estudo.

Figura 4.2 Vetor Noroeste inserção na macrometrópole paulista $X$ ABCD inserção metropolitana.

Figura 4.3 Espacialização PIB Municipal 2014: ABCD x Vetor Noroeste

Figura 4.4 Intensidade dos deslocamentos pendulares entre SP. e Rio e novas dimensões espaciais.

Figura 4.5 Rod. Anhanguera eixo de integração nacional e Eixos secundários do vetor noroeste.

Figura 4.6 Cond. Industriais rod. D.Pedro-Atibaia e Shopping e indústrias na rod. Stos Dumont -Indaiatuba.

Figura 4.7 Valores de investimentos em obras viárias e trem regional.

\section{CAPÍTULO V}

Figura 5.1 Múltiplas escalas - Vazio urbano Valinhos e sua relação macrometropolitana e Nacional.

Figura 5.2 Articulação Matrix-System. Conclusão matriz. Definição forma. Compatibilização escalas.

Figura 5.3 Matrizes elaboradas para Nova York, Los Angeles e Cidade do México.

Figura 5.4 Matrix System. Limites geográficos e eixos de conexão do estado e da macrometrópole de SP.

Figura 5.5 Sintetizando áreas verdes, eixos secundários e aglomerações urbanas e metropolitanas.

Figura 5.6 Rede de Conexões e centralidades para Transporte Orientado Sustentável - DOTS.

Figura 5.7 Linha Férrea, Eixo urbano de serviços antiga Estrada Boida, Condomínios Residenciais.

Figura 5.8 Área estendida : Síntese da Matrix - Infraestrutura cinza e verde.

\section{LISTA DE TABELAS, QUADROS E GRÁFICOS.}

\section{CAPÍTULO IV}

Gráfico 4.1 Evolução PIB 1970 - 2014 do Vetor Noroeste e do ABCD Paulista.

Tabela 4.1 Evolução de PIB - ABCD x Vetor Noroeste

Tabela 4.2 Dados sócio econômicos dos municípios do eixo Anhanguera, do ABC Paulista, e da Capital 
LISTA DE ABREVIATURAS E SIGLAS.

ARTESP Agência Reguladora de Serviços Públicos Delegados de Transporte do Estado de S.P.

CNAE Classificação Nacional de Atividades Econômicas - CNAE

CCR-Autoban Companhia de Concessões Rodoviárias - Autopistas Bandeirantes e Anhanguera.

DER Departamento de Estradas e Rodagem

DERSA Secretaria dos Transportes do Estado de São Paulo: Desenvolvimento Rodoviário S.A.

EMPLASA Empresa Paulista de Planejamento S.A.

IBGE Instituto Brasileiro de Geografia e Estatística

PIB Produto Interno Bruto

SAB Sistema Anhanguera Bandeirantes

SEADE $\quad$ Fundação Sistema Estadual de Análise de Dados

RMSP Região Metropolitana de São Paulo

RMC Região Metropolitana de Campinas

USD $\quad$ United States Dollar

ANEXO | Evolução PIB - IPEADATA SEADE 1970-2015

ANEXO II Evolução VA - IPEADATA SEADE 1970-2015 


\section{INTRODUÇÃO}

As tendências da urbanização incorporam transformações espaciais da economia e o espaço capitalista produzido, estrutura-se em redes de infraestrutura e é transformado, de acordo com os diferentes estágios deste processo de acumulação.

Denominamos de Novos Territórios Metropolitanos transformações urbanas recentes, decorrentes dos avanços dos processos de reestruturação produtiva da economia capitalista, que a partir do século XXI resultaram em um processo de urbanização diferenciado.

Dinâmicas de dispersão mais avançadas, ou seja, mais relacionadas à economia moderna, ou à dispersão do setor de serviços, promovem o adensamento de vazios urbanos, e produzem novos territórios metropolitanos que se constituem a partir da integração dos territórios dispersos vigentes no século XX.

A constante busca por novos conceitos e abordagens visa identificar rupturas, ajustes e permanências com dinâmicas urbanas anteriores, e permitir metodologias mais abrangentes e eficazes de intervenção nos novos Territórios Metropolitanos.

Busca-se aqui compreender a lógica e o impacto local e regional que dinâmicas mais intensas de dispersão urbana vem produzindo no tecido urbano de territórios localizados no vetor noroeste paulista, a partir do século XXI, no contexto de um estágio mais avançado do processo de acumulação capitalista, com o objetivo de alcançar novas práticas de atuação e gestão integrada neste território.

A pesquisa aborda um trecho de aproximadamente noventa quilômetros, compreendido entre a capital de São Paulo e o município de Campinas, estruturado pelo sistema de rodovias Anhanguera/Bandeirantes (SAB), e concentrador do segundo maior PIB do Estado, perdendo apenas para capital.

Trata-se do mais importante eixo produtivo regional do estado de São Paulo, pois conecta as duas mais ricas regiões metropolitanas do estado: São Paulo (aprox. 20.5 milhões habitantes) e Campinas (aprox.3 milhões habitantes). Além disso, do ponto de vista nacional, esse eixo estabelece a principal conexão entre a maior metrópole do país, São Paulo, e a capita federal, Brasília.

A pesquisa se concentra nos municípios localizados no eixo da rodovia Anhanguera, que por ser tratar de uma rodovia antiga e com maior acessibilidade, apresenta maior concentração de ocupações ligadas ao setor terciário, ou seja, mais relacionadas aos avanços do processo de reestruturação produtiva. 
Parte-se da hipótese, que esse território, ao longo do eixo da rodovia Anhanguera, em sua forma atual, assume novos padrões de urbanização, que vem produzindo novas formas de tecido urbano ao longo do vetor noroeste paulista, que requer um novo olhar devido à complexidade de suas relações espaciais.

Ou seja, transformações econômicas e sociais, necessárias para manutenção da acumulação da economia capitalista, têm gerado novas formas de organização social, que vem produzido novas configurações e dimensões territoriais.

Expressões como Territórios da Dispersão (Viganò, 2010), Reterritorialização ( Brenner 2010), cidades-região ( Soja, 2013), Região Urbana (Lencioni, 2015) e Paisagem Operacional ( Brenner 2015), trazem novas abordagens para se referir às novas escalas que a intensificação das dinâmicas de dispersão vem produzindo.

Inserem-se neste debate reinterpretações morfológicas sobre fragmentação, totalidade, continuidade, coesão e porosidade territorial.

Conforme Secchi, 2009, a cidade do passado era representada por contrastes entre cidade-campo. Depois, pela concentração urbana e continuidade territorial da cidade industrial. A seguir, os novos territórios dispersos produzidos ao longo do século XX apresentam descontinuidade territorial, representada mais por porosidades do que por ocupações dispersas, ou pela tensão entre cheio e vazio.

Contudo transformações urbanas recentes equilibram e alteram essas relações morfológicas vigentes no século XX, produzindo mais coesão territorial e integração das partes de um todo disperso e fragmentado que cada vez mais se configura com contornos mais nítidos, configurando novos Territórios Metropolitanos, que sobrepõem temporalidades e não se inserem em limites administrativos estabelecidos.

A partir de um referencial teórico estabelecido, com ênfase para Reis $(2015,2007,2006)$, a análise do vetor noroeste se estrutura tendo em vista que cada vez que se analisa uma determinada região, deve-se compreender que houve uma forma de desenvolvimento econômico relacionada a uma técnica ou infraestrutura correspondente, e que esse espaço, além de produzido é alterado, sobreposto, e está em constante processo de transformação e expansão.

Ou seja, trata-se do processo de evolução de um eixo histórico que, desde o século XVIII, tem como principal função o transporte das riquezas entre o próspero interior, a capital e o porto de Santos. Os principais ciclos de desenvolvimento econômico desse vetor (Ouroséc. XVIII; Café-séc. XIX; Industrialização-1940/50; Desconcentração Industrial-1970; 
Reestruturação Produtiva-1990), foram possibilitados por diferentes infraestruturas cuja evolução técnica serviu como suporte espacial a esse desenvolvimento econômico, e, ao mesmo tempo, permitiu que escalas urbanas estendidas se manifestassem nesse território (EIGENHEER, 2011).

As dinâmicas de dispersão urbana têm início nesse vetor a partir de 1970, no contexto da desconcentração das atividades industriais, da capital rumo ao interior e outros estados. A seguir, partir de 1990, as dinâmicas de dispersão urbana são intensificadas no contexto da reestruturação produtiva e da globalização (REIS, 2007,2006).

Contudo, a partir de 2000, devido à intensificação e modernização dos processos anteriores, observa-se que novos aspectos morfológicos, distintos daqueles apresentados pelas tradicionais dinâmicas de dispersão, passam a caracterizar o tecido urbano dos municípios localizados no eixo da rodovia Anhanguera.

A partir do novo século, além das dinâmicas de dispersão industrial e urbana, observa-se também a dispersão do setor de serviços que vai acompanhar as dinâmicas anteriores e acarretar transformações nesse novo território metropolitano.

Embora essa dinâmica de urbanização avançada, caracterizada principalmente pela dispersão do setor de serviços, manifeste-se em todo o território estruturado pelo sistema de rodovias Anhanguera/Bandeirantes; ela se torna mais evidente nos municípios com formação recente onde esses novos usos predominam no território.

Cajamar (75 mil hab), Louveira (46 mil hab), Vinhedo (75 mil hab), e Valinhos (122 mil hab), enquadram-se neste contexto e serão aqui designados como municípios de pequeno porte para diferenciá-los dos municípios com área e arranjos populacionais maiores que também compõem o eixo Anhanguera como São Paulo (11.754 mil hab), Campinas (1.159 mil hab) e Jundiaí (401 mil hab).

Observa-se que esses municípios de pequeno porte estão inseridos em um mesmo contexto geográfico e econômico. Porém, apesar de incorporarem nas dinâmicas urbanas de seus territórios um estágio mais avançado do processo de reestruturação produtiva, pertencem a diferentes regiões administrativas.

Valinhos e Vinhedo (6o PIB per capita do estado) pertencem à região metropolitana de Campinas. Louveira (1ํ PIB per capita do estado), pertence à aglomeração urbana de Jundiaí. Cajamar está inserido na região metropolitana de São Paulo. Portanto, questões políticas interferem nas possibilidades ou impossibilidades de uma gestão mais abrangente e integradora deste corredor. 
Através de observações empíricas e da interpretação e comparação de mapeamentos existentes e de imagens de satélite e ortofotos obtidas em instituições públicas e empresas privadas, a pesquisa se aprofunda no entendimento do processo de transformações do tecido urbano dos municípios de pequeno porte, atravessados pelo eixo Anhanguera.

Como dito, o recente processo de urbanização desses municípios permite melhor evidenciar as recentes dinâmicas de dispersão que predominam em seus territórios, e que se sobrepõem às dinâmicas anteriores, fortalecendo centralidades e produzindo complexidade espacial e segregação territorial.
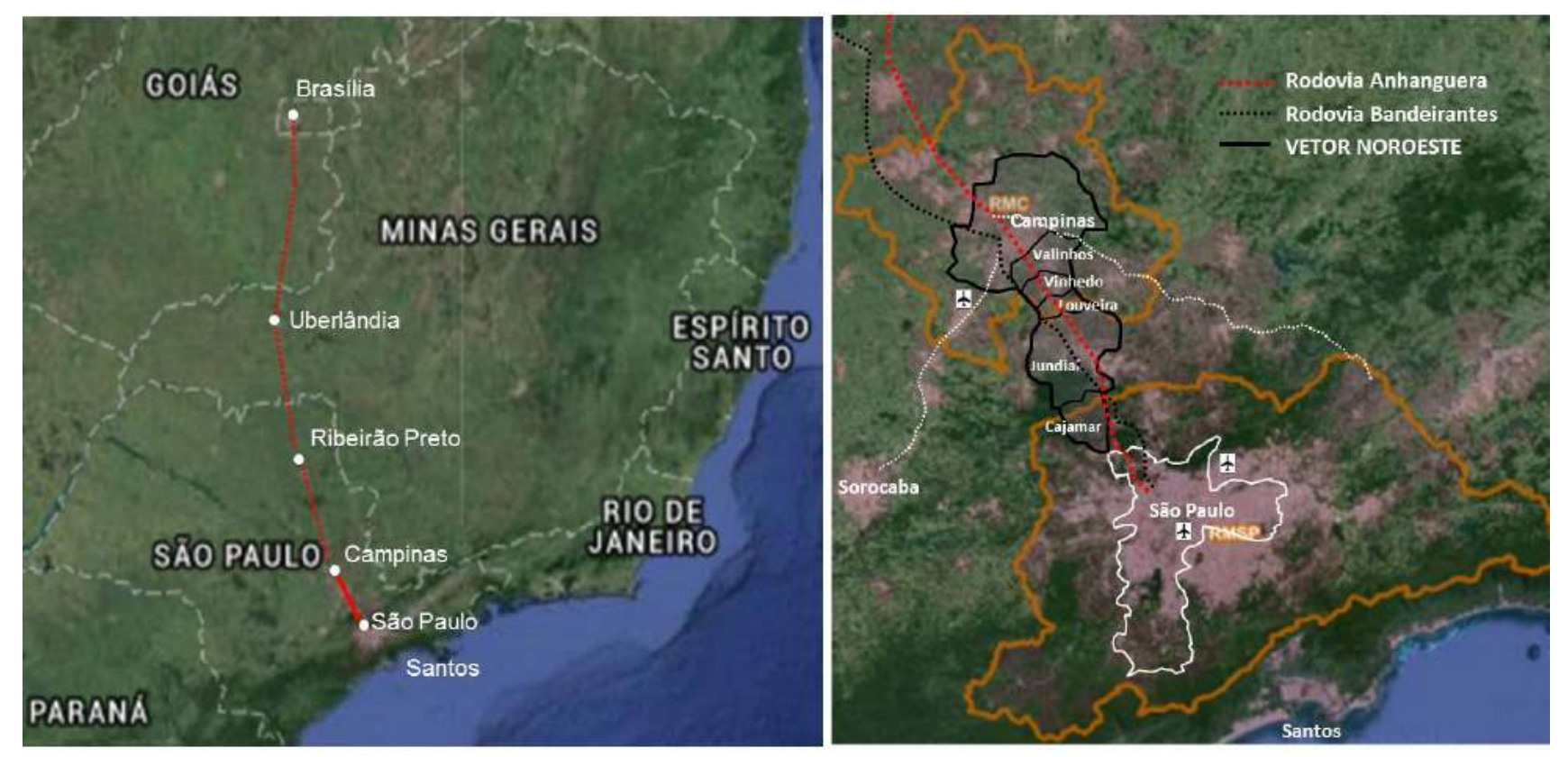

Figura 1 - Vetor Noroeste e o Eixo Anhanguera, inserção nacional, estadual e metropolitana.

Fonte: Elaborado a partir de imagens http://www.emplasageo.sp.gov.br.

Do ponto de vista regional, na primeira década do século XXI, dados obtidos do SEADE, demostram uma transição da geografia da economia paulista. Em 2014, o segundo maior PIB paulista, desloca-se da região metropolitana do $A B C D$ paulista para o vetor noroeste paulista (eixo São Paulo-Campinas), o que tem acarretado, além de um significativo impacto territorial, o fortalecimento da escala macrometropolitana.

Além disso, eixos produtivos secundários, localizados no vetor noroeste paulista, que se relacionam diretamente com o eixo Anhanguera/Bandeirantes, também passam a se desenvolver e a atrair usos relacionados às dinâmicas mais avançadas de dispersão, fortalecendo centralidades e um novo arranjo produtivo. 
O entendimento das múltiplas relações espaciais e da totalidade que esses territórios metropolitanos contemporâneos estruturados por eixos produtivos compõem, requer novas abordagens mais integradoras que evitem a fragmentação do espaço nacional.

Devido à ausência de políticas públicas metropolitanas e regionais, com atuação mais abrangente e integrada nesse território estendido (vetor noroeste paulista), que não se insere nos limites municipais e metropolitanos atualmente estabelecidos, a pesquisa se aprofunda na teoria de Viganò (2015) e Ortiz, (2013), que se baseiam respectivamente em novas formas de abordagens e metodologias capazes de atuar nas múltiplas escalas que os complexos territórios metropolitanos estabelecem na contemporaneidade.

Desenvolvido no quinto capítulo, o método, Matrix System (ORTIZ, 2013), estrutura-se em três etapas: análise do território e seus principais desafios; síntese das soluções para os desafios encontrados; proposta e desenvolvimento de um plano de ação local e regional baseado na matriz construída.

A primeira etapa de Análise foi estruturada na abordagem de dois subsistemas básicos necessários para abordagem de territórios metropolitanos: O primeiro, constituído de Infraestrutura (gray infrastructure) e Meio Ambiente (green infrastructure), e considerado subsistema contínuo. O segundo, Habitação (housing), Instalações Produtivas (productive facilities), Equipamentos Sociais (social facilities), considerado um subsistema que se distribui de forma descontínua pelo território.

Na segunda etapa, de Síntese, origina-se uma matrix de integração entre meio ambiente, transporte e estruturas urbanas, cada aglomeração urbana ou metropolitana deve coordenar os cinco subsistemas.

$\mathrm{Na}$ terceira etapa, após a análise da matriz, define-se uma forma específica para cada região e as tendências naturais para a evolução desta forma, ou seja, desenvolve-se uma proposta ou plano de ação territorial.

O aprofundamento neste método, bem como, sua aplicação no vetor noroeste paulista, foi realizado durante um estágio de quatro meses no DASTU - Departamento de Arquitetura e Estudos Urbanos da Universidade Politécnica de Milão com co-orientação da professora Doutora Antonella Contin e do professor Pedro Ortiz, criador do método e professor visitante na Universidade de Milão.

Esta tese se desenvolve em cinco capítulos estruturados a partir da bibliografia básica e principais autores que serão seguir apontados. 
O primeiro é teórico e aborda a evolução das relações de produção do espaço capitalista tendo em vista os avanços das tecnologias de comunicação e das infraestruturas de transporte, bem como, formas mais avançadas de produção e urbanização. (CASTELLS, 1999; HARVEY, 1992; INDOVINA, 2004; LENCIONI 2015, REIS, 2006,2007,2015; SECCHI, 2009; SCHIFFER, 1989, VIGANÒ, 2010).

O segundo aborda a evolução histórica e as transformações recentes nas dinâmicas econômicas e urbanas do vetor noroeste paulista (industrialização, desconcentração industrial, dispersão urbana e urbanização avançada), possibilitadas pela evolução técnica de sua rede de infraestrutura, estrategicamente prevista para atender determinados ciclos produtivos, que demandam novos padrões de mobilidade, que por sua vez, permitem que novos usos e escalas territoriais se manifestem e se sobreponham. (CANO, 1998; EIGENHEER, 2011; EMPLASA, LANGEMBUCH 1971, LENCIONE, 2004; REIS, 2006,2007; SPÓSITO, 2007).

O terceiro capítulo apoia-se em observações empíricas e no impacto que a intensificação das recentes dinâmicas de dispersão, com ênfase para o setor e serviços, tem promovido na configuração morfológica do tecido urbano de municípios de pequeno porte localizados no eixo Anhanguera (CANO, 2002, EMPLASAGEO, SSR Tecnologia, Prefeituras).

O quarto capítulo apóia-se em dados de mobilidade e socioeconômicos, e abordará a configuração de novos arranjos produtivos, e a transição da economia paulista da escala metropolitana para a escala macro-metropolitana. Decorrente deste processo observa-se o fortalecimento e a integração de novas centralidades, e o surgimento de novas dimensões espaciais estruturadas por novos corredores de riqueza, bem como a necessidade uma nova forma de gestão integrada deste complexo território estendido. (BORJA,1998, CUNHA, 2013, EMPLASA, LANGEMBUCH 1971, HARVEY, 1981; NEGRI, 1996; NOBRE, 2000; SCHIFFER, 2004, SEADE, SOMEKH,2005).

O quinto capítulo, a partir das análises anteriormente descritas, propõe-se a construção de um método baseado em um sistema de matrizes (CITI/Metro-Matrix), que estrutura um plano regional para ser aplicado na integração e gestão do vetor noroeste paulista. (CONTIN,2015; ORTIZ,2013; VIGANÒ, 2010). 
Aborda-se aqui a evolução das relações de produção do espaço capitalista tendo em vista os avanços das tecnologias de comunicação e das infraestruturas de transporte, bem como, formas mais avançadas de produção que estendem a lógica metropolitana e redefinem novos territórios e conceitos morfológicos. 


\subsection{Produção do Espaço Capitalista: Tecnologia e Infraestrutura e Dispersão Urbana.}

Para Nestor Goulart Reis há uma relação direta e intrínseca entre as formas de organização social e as formas de organização do espaço (REIS, 2006, 2007, 2015). Toda relação social se organiza no espaço, pelo simples fato de que se dá entre pelo menos duas pessoas, e uma não existe sem a outra. A relação entre pessoas se define no espaço, por proximidade e distanciamento, por formas diferentes, mas sempre se define no espaço, é uma questão conceitual (REIS, 2015).

Segundo o mesmo autor, as relações sociais se desenvolvem simultaneamente, tanto no âmbito econômico, como no político, no cultural e no ideológico. Partindo deste pressuposto teórico, conclui-se que a produção ou a transformação do espaço ocorre em decorrência de alterações nas relações econômicas, políticas, culturais e ideológicas, o que torna seu entendimento um processo complexo com múltiplos desdobramentos, que vão muito além da simples observação empírica de alterações nas configurações territoriais. Nós vemos apenas uma parte do espaço, nós não podemos ver o espaço todo, que é uma construção teórica, uma construção mental, nós não temos esta possibilidade. Temos que trabalhar com o material e com o social simultaneamente (REIS, 2015).

Da mesma forma, a teoria de Gottidiener (1993), defende que os fenômenos urbanos são resultantes de mudanças na organização social e que a vida cotidiana na sociedade moderna ocupa um papel fundamental neste processo. Além disso, considera o estudo exclusivo da morfologia urbana ou aqueles que se baseiam apenas em transformações econômicas, sejam insuficientes para se compreender tal processo.

Santos (1996), define a diferença entre o espaço e o território. Para o autor o espaço é entendido como um sistema de fluxos, de formação desigual, resultante do desenvolvimento das forças produtivas, das relações de produção e das necessidades de circulação e distribuição.

Já o território é formado pelos complexos naturais existentes e pelos acréscimos ou construções realizados pelo homem como as plantações, as infraestruturas, e a urbanização. Para o autor o espaço é uma totalidade cuja essência é social, englobando simultaneamente, o concreto e o abstrato. " A configuração territorial não é o espaço, já que sua realidade vem de sua materialidade, enquanto o espaço reúne a materialidade e a vida que o anima " (SANTOS,1996, p.51). 
Raffestini (1993) aborda de maneira bem sistêmica todas as relações de poder que são estabelecidas no território. Para o autor o território se forma a partir do espaço, resultado de uma ação conduzida por um ator que "territorializa" esse espaço.

De acordo com o mesmo autor, a produção de um espaço, o território nacional, compreende o espaço físico, balizado, modificado, transformado pelas redes, circuitos e fluxos que aí se instalam: rodovias, canais, estradas de ferro, circuitos comerciais e bancários, auto-estradas, rotas aéreas etc. Ou seja, o território é um espaço onde se projetou um trabalho, e que revela relações marcadas pelo poder.

Elementos como modos de produção, distribuição da população, infraestrutura, urbanização e sistemas de fluxos, têm forte influência na forma como o espaço se estrutura. Portanto, são fundamentais para compreensão da totalidade desse espaço de produção e consumo, e para identificação das desigualdades geradas pelo sistema capitalista.

Neste contexto, e concentrando-se nas relações sociais de produção do espaço capitalista, que se baseiam principalmente nas relações entre produção, troca e consumo, ressalta-se a importância das tecnologias que ao longo do tempo, alteram essas relações, ao mesmo tempo em que alteram as bases da vida social e da existência material e, portanto da produção do espaço.

Observa-se na história da ciência que alguns desses conhecimentos sobre novas técnicas levaram séculos até serem incorporados. Os avanços tecnológicos só se tornam socialmente relevantes e espacialmente transformadores, quando são incorporados ao processo de produção e ao de consumo (REIS, 2015).

A introdução de inovações técnicas nos processos produtivos tornou a indústria o setor dominante na economia. A industrialização no século XIX, provocou a atração da cidade /campo, o êxodo rural e o esvaziamento do espaço agrário.

Da mesma forma, no final do século XX, o espaço urbano começa a perder sua realidade geopolítica devido às tecnologias de comunicação instantâneas, que possibilitam o progresso sem deslocamentos físicos, o que altera a lógica das cidades e perturba as estruturas urbanas e sociais (VIRILIO, 1993).

Conforme Secchi (2007), a dispersão urbana, expressão espacial do modelo de produção do espaço a partir da segunda metade do século XX, não foi causada, mas foi possibilitada pelo desenvolvimento e incorporação de novas técnicas, em especial as 
relacionadas com mobilidade, como a difusão do automóvel e o avanço das tecnologias de comunicação.

A crescente possibilidade de realizar atividades rotineiras através das novas tecnologias de informação não só altera a lógica dos deslocamentos físicos atuais, como também acelera o ritmo da vida social, aumentando a quantidade de atividades desempenhadas devido à compressão do espaço e do tempo. "O domínio dos espaços e dos tempos é um elemento crucial na busca do lucro" (HARVEY,1989, p. 207).

As tecnologias permitiram que a acumulação do capital se desprendesse de barreiras físicas, passando a circular instantaneamente e sem regulação. "Quanto mais rápida a recuperação do capital posto em circulação, tanto maior o lucro obtido. O efeito geral é, portanto colocar no centro da modernidade capitalista a aceleração do ritmo dos processos econômicos e, em consequência, da vida social" (HARVEY,1989, p. 209-210).

Conforme Secchi (2007), essas técnicas não surgem aleatoriamente e por serem decisivas na alteração das dinâmicas urbanas e sociais, merecem uma atenção maior e mais crítica. Observa-se na história que o progresso técnico, inclusive no transporte de pessoas e mercadorias, permitiu na Europa, ao longo do século 18, o aumento da concentração urbana e metropolitana (aquedutos, esgotos, pavimentação, iluminação, aquecimento e transportes), pois as relações produtivas e de trabalho exerciam pressão nesse sentido.

Os Investimentos públicos e a evolução tecnológica permitem alterar as relações produtivas promovendo as economias e/ou deseconomias de aglomeração, criando, reforçando, ou desestruturando determinadas regiões produtivas e alterando, dessa forma, as relações de produção, consumo e troca. Portanto, alteram-se as relações sociais, sua dimensão e localização, portanto, altera-se o espaço.

A expansão da rede ferroviária, o surgimento da eletrificação, do telefone, do fax (que permite finalmente distanciar o escritório da fábrica, gerando o zoneamento setorizado, zonas de negócios e bairros segregados), do rádio, da televisão (que permitem trazer o laser dos centros urbanos para dentro de casa), das infraestruturas viárias que permitem o aumento da mobilidade e o encurtamento das distâncias, e mais recentemente, das tecnologias de informação que permitem ultrapassar barreiras físicas ou a conexão global, são inovações técnicas voltadas a se evitar a concentração e permitir a dispersão.

O aumento da mobilidade física e virtual possibilita relações sociais independentes que ultrapassam limites físicos estabelecidos. Esse avanço atende aos anseios da 
contemporaneidade e seus reflexos urbanos, que ainda observamos, serão aqui aprofundados.

O que se enfatiza aqui é que as transformações urbanas não são decorrência direta da evolução de novas técnicas, e que estas podem gerar, tanto concentração, como desconcentração urbana, ou ambas simultaneamente. Como dito, inovações técnicas não surgem ao acaso, mas atendendo a novas demandas econômicas ou sociais.

Quando incorporadas as tecnologias produzem transformações nas relações sociais e produtivas, que por sua vez, estabelecem novas relações no território, produzindo impacto urbano.

Por outro lado, na produção do espaço capitalista que se estrutura em redes de infraestrutura, outra forma de gerar valor, sem que seja na produção, propriamente dita, é na produção de infraestrutura, pois esta, além de possibilitar a expansão da produção para novos territórios e promover facilidades de deslocamento e redução de custo dos produtos, altera o valor de mercado das áreas, em função da oferta de acessibilidade e produção (REIS, 2015).

Portanto, na sociedade capitalista, a produção do espaço deixa de ser algo que faz parte de um investimento fixo, e passa ser parte das trocas da sociedade, ou seja, na sociedade industrial, a produção material do espaço (edificações e infraestruturas) passa a ser a principal forma de investimento.

O mercado imobiliário, financiado pelo setor financeiro, torna-se um importante agente transformador do espaço e as infraestruturas se tornam centrais neste contexto, na medida em que produzem novas localizações.

Observa-se um processo de valorização imobiliária das novas áreas, que se tornam além de produtivas, acessíveis. Portanto, a infraestrutura é um importante produto imobiliário, gerador de riqueza e transformador do espaço urbano, na medida em que permite a extensão das relações sociais e a produção para outras escalas.

O maior investimento social é o da produção e o da infraestrutura, isto é fundamental para o entendimento dos processos de urbanização (REIS, 2015). Cada vez que se analisa uma determinada região, deve-se observar que houve uma forma de desenvolvimento econômico relacionada a uma técnica ou infraestrutura correspondente, e que esse espaço, além de produzido é alterado, está em permanente processo de transformação.

A contínua alteração espacial advém da essência do modo de produção capitalista que é a constante busca do lucro, obtido através da livre circulação de mercadorias e a 
constante abertura de novos mercados, que garantam a manutenção e expansão da acumulação do capital (SHIFFER ,1989).

Isso requer a constante transformação nos padrões de mobilidade e de infraestrutura de transportes, que garantam um progressivo aumento e fluidez de fluxos de mercadorias e pessoas. Diante deste processo alteram-se as escalas de produção, de troca e de consumo, ampliam-se os mercados, a atuação imobiliária, e as relações sociais. Ou seja, as atividades da vida cotidiana também passam a ocorrer em nova escala ou localização.

Segundo Schiffer (1989), produzir o espaço capitalista implica construir ligações entre as localizações, para a constituição de um território homogêneo, onde a forma-mercadoria possa se implantar e deslocar. As infraestruturas são o suporte material físico que permite o processo de transformação e extensão das escalas urbanas. Portanto, o espaço capitalista produzido estrutura-se em redes de infraestrutura e é transformado, de acordo com os diferentes estágios deste processo de acumulação.

Ao mesmo tempo, a implantação de infraestruturas, visando melhor atender a determinados ciclos produtivos e alterar o valor de uso das localizações, propicia transformações no uso do solo, o avanço da mancha-urbana, o enfraquecimento de áreas centrais e novas polarizações, direcionando a expansão urbana e estruturando novas dimensões espaciais que requerem atenção.

Portanto alteração nas demandas produtivas suportadas por avanços tecnológicos com ênfase nos setores de transporte e comunicação, alteram os deslocamentos e as dinâmicas de mobilidade, bem como a distribuição da população e de suas atividades sobre o território, reestruturando e direcionando a evolução e expansão urbana.

No contexto mundial e do ponto de vista econômico, transformações nos processos produtivos e evolução técnica, são advindas do pós-guerra. A evolução destas transformações constituirá, a partir de 1970, uma nova etapa do capitalismo, que viabilizará uma nova lógica territorial e espacial. A acumulação do capital não mais advirá da indústria tradicional, mas agora, do setor de serviços advindo da modernização e fragmentação da indústria, e do setor imobiliário e financeiro, (HARVEY,1992).

No Brasil, ao longo do século XX, Reis (2007), descreve algumas importantes mudanças no processo de urbanização, decorrentes de avanços técnicos e produtivos. A explosão demográfica decorrente da melhoria das condições de vida, devido aos avanços da medicina e saneamento, na virada do século XIX. No século XX, a explosão urbana decorrente da revolução industrial e das migrações campo-cidade, e a explosão metropolitana decorrente da intensificação da industrialização e da implantação de 
infraestruturas viárias que permitirão uma nova espacialização da indústria consolidando os processos de metropolização, e de dispersão industrial.

A continuidade dos processos de modernização e fragmentação industrial, ou seja, a multiplicação das áreas metropolitanas, decorrente da restruturação produtiva, ou da universalização dos mercados e dos modos de produção, atrelada à globalização e às novas tecnologias de comunicação consolidam as dinâmicas de dispersão urbana, como veremos adiante.

E finalmente, decorrente da evolução do processo anterior, observa-se no século XXI, a universalização dos modos de consumo padronizados em massa, que cada vez mais tem permitido a difusão do setor de serviços que passam a se organizar em rede, acarretando difusão também do modo de vida, bem como, que novas relações espaciais se estabeleçam no território, objeto de estudo desta pesquisa.

Partindo do exposto, entendemos a existência simultânea da configuração de dois modelos do espaço capitalista. Um é decorrente do modo de produção industrial que levou a explosão urbana e ao crescimento das metrópoles e suas regiões metropolitanas.

O outro, expressão espacial do capitalismo pós-industrial ou contemporâneo, é a extensão das regiões metropolitanas, que assumem novos contornos, devido às transformações econômicas e à nova configuração da indústria moderna, dando início às dinâmicas de dispersão urbana e de valorização imobiliária.

Como era previsível, essa história implica duas sequências: a primeira é construída sobre a experiência da concentração urbana progressiva, a segunda sobre a da fragmentação e dispersão da megalópole nos territórios de dimensão inimagináveis (SECCHI,2009,p.34).

Esse território estendido ou disperso, já bastante analisado por diversos autores, é designado de diferentes formas: Metápole (ASCHER, 1995); Cidade Difusa (INDOVINA, 1997); Cidade Dispersa (MONCLÜS, 1998); Postmetrópolis e seus desdobramentos (SOJA, 2000); Cidades Regiões Globais (SCOTT, 2001); Regionalização do Espaço (LENCIONI, 2004); Urbanização Dispersa (REIS, 2006); Urbanização Extensiva (DOMINGUES, 2008); Urbanização Difusa (SPÓSITO, 2009); Reterritorialização (BRENNER, 2010).

Essas múltiplas terminologias constituem referências decorrente do local onde a dinâmica é observada. Não se trata aqui de analisar qual conceito seja mais apropriado ou de sugerir uma definição mais adequada para as dinâmicas de dispersão urbana. Essas múltiplas definições, servem para alertar sobre a complexidade dessas relações, e 
principalmente que as dinâmicas de extensão territorial não são genéricas, universais e nem estáticas, portanto devem ser observadas e analisadas dentro do contexto e do tempo em que se inserem, a fim de que sejam compreendidas.

Para Ascher (1995), a concentração da população nas grandes cidades (metropolização) produz uma nova forma urbana que ele denomina Metápole: um vasto território heterogêneo, sem limites físicos precisos, marcado por uma mobilidade constante e pelo desaparecimento das relações de proximidade. A preocupação do autor esta em entender como evoluem nesses espaços as práticas sociais, frente à fragmentação social e espacial desse novo território.

Indovina define a Cidade Difusa a partir do avanço de áreas urbanas sobre as áreas rurais, tendo em vista a região do Vêneto na Itália. A cidade difusa se caracteriza pela dispersão de uma urbanização de baixa densidade, grande mobilidade de pessoas, mercadorias e informações, bem como, mudanças dos modos de vida da população urbana e rural.

Enquanto Monclús teoriza sobre as "novas periferias", resultado de uma ruptura total no tecido urbano decorrente do avanço das telecomunicações. Soja utiliza o termo Postmetrópolis e seus desdobramentos a fim de ressaltar as diferenças entre as regiões urbanas contemporâneas e aquelas que se consolidam em meados do século $X X$. Através do prefixo pós enfatiza a transição da metrópole moderna para algo novo inserido no contexto da pós modernidade.

Para Scott (2001), as Cidades Regiões Globais são locais privilegiados com vantagens competitivas, onde o mercado global e as novas tecnologias do transporte e das comunicações incentivaram uma reestruturação da competição econômica.

Trata-se de lugares onde economias altamente produtivas e inovadoras estão presentes, mas tratam-se também de lugares onde as falhas multifacetadas do mercado, desequilíbrios históricos e relações brutais de poder do processo de desenvolvimento estão dolorosamente evidenciados (SCOTT, et al. ,2004, p. 22).

Domingues (2008), fala sobre urbanização extensiva e territórios desconfinados, ressaltando a percepção de múltiplas dimensões que estruturam essas dinâmicas.

No Brasil, vários autores abordam a reestruturação territorial e urbana advinda do processo de reestruturação produtiva instalado no país a partir de 1990.

Lencioni (2004), atenta para a regionalização do espaço que implica na extensão das dinâmicas metropolitanas para outros territórios, que vão além de seus limites territoriais, 
o que torna necessária uma reflexão voltada não mais sobre o contexto metropolitano, mas sobre a regionalização de áreas que se inserem em um mesmo contexto urbano e econômico.

Reis $(2006,2007)$, caracteriza a espacialização do fenômeno da dispersão urbana a partir do esgarçamento do tecido urbano e da constituição de nebulosas, tendo em vista a difusão dos modos de vida, ou das relações sociais, bem como, a dispersão industrial iniciada, a partir da década de 1970 no estado de São Paulo, e apoiada pelo avanço técnico de sua rede de infraestrutura rodoviária.

Para Reis (2006), tanto as razões de ordem técnica, quanto a reorganização internacional do capitalismo (a reorganização produtiva) levaram a descentralização e à dispersão industrial, cuja dinâmica e evolução esta pesquisa objetiva se aprofundar, tendo em vista o vetor noroeste da capital paulista, eixo São Paulo-Campinas. Incluímos aqui também a questão fundiária e imobiliária que também contribuem para a formação de territórios estendidos.

Já Spósito (2009), denomina esse processo de urbanização difusa, enfatizando mais a intensificação da novas dinâmicas de mobilidade propiciadas pelas nova tecnologias de comunicação que ampliam e aceleram as formas de se deslocar e de se comunicar, produzindo descontinuidades territoriais. A cidade em contraponto ao campo se encontra em processo de dissolução, em função do espraiamento do seu tecido urbano. Cada vez menos se percebe com clareza, onde termina a cidade e começa o campo e cada vez mais se intensificam os fluxos.

Meyer (2015), ao abordar o processo paulista e paulistano de restruturação do território, caracteriza-o por uma acentuada descontinuidade territorial associada à dispersão de novos usos e à formação de novas centralidades, onde dois padrões se manifestam: fragmentação territorial e dispersão funcional. Enfatiza a necessidade do aprofundamento desta análise tendo em vista uma perspectiva histórica, ou seja, a evolução dos processos de expansão territorial, bem como, o papel que a metrópole paulista exerce dentro do panorama do capitalismo global.

Segundo Pacheco (1998), da mesma forma que o desenvolvimento industrial determinou não apenas o ritmo de crescimento, mas muitas vezes a geografia do crescimento urbano da metrópole de São Paulo, embora esse processo também se relacione com seu passado cafeeiro, a partir da década de 90 , é o setor terciário metropolitano advindo dos processos de reestruturação produtiva, que assume esse papel, transformando a 
metrópole industrial na metrópole dos serviços, trazendo reconfigurações espaciais e a extensão da escala metropolitana.

Decorrentes da restruturação produtiva, o que parece comum à constituição dessas novas escalas e formas de expansão urbana, sejam elas dispersas, difusas ou descontínuas, é sua estruturação através de redes de infraestruturas físicas e virtuais, que possibilitam o seu descolamento físico de áreas centrais consolidadas, e a perda de continuidade e de unidade territorial que sempre caracterizaram as formações urbanas tradicionais, sejam elas metropolitanas ou simples aglomerações urbanas.

No entanto, Secchi (2009), observa que a dispersão da cidade europeia e ocidental, pode ser interpretada como uma forma de degradação da cidade moderna e das formas urbanas que a precederam. Ou então, como um estágio evolutivo necessário que antecipa uma forma diferente de habitar, ocasionando inquietações. A busca da continuidade territorial é cada vez mais confrontada por dois fenômenos diretamente relacionados: dispersão e fragmentação.

No entanto, tendo em vista recentes dinâmicas de dispersão urbana, mais avançadas e intensas, que se manifestam nos territórios contemporâneos, esse confronto parece se dissipar.

A partir do exposto, a seguir, serão abordadas as alterações morfológicas e espaciais que a evolução das dinâmicas de dispersão urbana vem suscitando no território do novo século. 


\subsection{Economia Moderna e Novas Dinâmicas de Dispersão Urbana.}

Conforme Castells (1999), quanto maior a inserção de uma aglomeração urbana na economia moderna, maior será o papel de seus serviços avançados e maior será a reestruturação do seu espaço urbano. Da mesma forma, as economias menos avançadas manterão uma estrutura urbana mais tradicional e rígida, sem grandes alteração em suas dinâmicas urbanas.

Segundo Reis (2015), quanto mais especializado um lugar, maior seu consumo e maior sua inserção nas novas dinâmicas da economia moderna e, portanto mais nitidamente se observam as dinâmicas de dispersão e transformação urbana.

Secchi (2009), atenta para a constituição da cidade e dos territórios mais densamente urbanizados do século XX, representados mais pelo predomínio de porosidades do que pela dispersão. A relação que Porosidade e Dispersão estabelecem no território também os diferencia. Trata-se de elementos que se penetram e se dissolvem reciprocamente no território, e que não se contrapõem, nem reproduzem a mesma tensão existente nas relações passadas entre cidade e campo.

Como visto, do ponto de vista intraurbano e morfológico, as dinâmicas de dispersão apresentam ausência de limites urbanos bem definidos, extensas ocupações territoriais com baixas densidades, vazios urbanos ou porosidades, reduzida coesão territorial, descontinuidade do tecido urbano e fragmentação territorial e espacial, com produção de territórios contíguos que em sua grande maioria são se relacionam na escala local, mas estabelecem relações espaciais, muitas vezes bastante complexas.

No entanto, o que a pesquisa observa, é que no século XXI, territórios com economia e urbanização avançada ou com intensificação das dinâmicas de dispersão urbana, apresentam alteração na sua constituição, apresentando uma morfologia urbana mais caracterizada por ocupações dispersas do que por porosidades ou espaços vazios.

Nos últimos anos, tendo em vista a intensificação das dinâmicas de dispersão urbana no território constitui-se uma bibliografia diferenciada que redefine algumas questões.

$\mathrm{Na}$ Europa, observa-se a continuidade do termo "” sempre se relacionando com as dinâmicas de dispersão urbana, como a permanência da expressão "cidade difusa" que se estende até o novo século nas obras de Indovina (2004) e Secchi (2009).

Conforme veremos a seguir, alguns autores e pesquisas propõem novas abordagens para se referir as novas escalas que as recentes dinâmicas de dispersão vêm produzindo, colocando o território, a região e a paisagem, no centro do debate. 
Além disso, características de morfologia urbana, como integração, porosidade, coesão e continuidade territorial são aprofundadas e redefinidas modificando em alguns aspectos 0 ponto de vista sobre as dinâmicas de dispersão.

Conforme Viganò (2010), algumas análises como a imagem da Europa à noite, revelaram uma continuidade e proximidade incomparáveis entre lugares no passado distintos e separados. Os territórios da dispersão têm desempenhado um papel importante na formação de um discurso na cidade contemporânea propondo um novo objeto de pesquisa e projeto, revelador de novas escalas, tecidos e paisagens. Foi necessário inovar as definições, produzir imagens e metáforas, para restituir um quadro pouco nítido, nunca totalmente compreendido.

Viganò (2010), utiliza-se da expressão "territórios de dispersão" para abandonar a difícil busca de uma analogia com o fenômeno urbano e interpreta a nova condição de assentamento como algo que extrapola a cidade. A autora define a cidade compacta, a cidade difusa e os territórios de dispersão (hoje um dos principais campos da investigação), como categorias de análises que se inter-relacionam e que sinalizam diferentes relações sociais e redefinem formas contemporâneas de se viver.

Segundo a autora, esses territórios foram observados como um momento de ruptura e dissolução da cidade, mas também, seguindo a interpretação de alguns geógrafos e economistas italianos entre os anos 60 e 90, como um fenômeno que reduziu os contrastes, tornou um território mais coeso, introduzindo novas formas de produção e ocupação territorial.

As duas interpretações, a da ruptura de um equilíbrio anterior entre a cidade e o campo e a de continuidade de uma prática alargada do território possibilitada por uma extensa infraestrutura, requerem a construção de novos lugares onde diferentes dinâmicas possam coexistir e gerar novos espaços de compartilhamento, mas também de autonomia e apropriação (Viganò ,2010).

Do ponto de vista morfológico a autora atenta para a força do termo Porosidade, uma ferramenta útil para descrever e projetar cidades e territórios contemporâneos e descobrir as grandes mudanças que eles estão submetidos hoje. Porosidade refere-se à densidade, distâncias, levando em consideração elementos de racionalidade ecológica, mas também tem profundas implicações sociais, podendo ser caracterizada de duas formas.

A primeira, tem a ver com a natureza ou estrutura porosa do material, a segunda é uma porosidade resultante de eventos traumáticos. Esta última muitas vezes, se manifesta no final de um período econômico ou social, é seguida de uma ruptura nas formas de uso do 
espaço e permite repensar a cidade, a partir da extensão e da importância da fratura que ocorreu. Difícil de ser prevista, mas importante de ser idenfificada, a porosidade deve ao menos ser lida e reconhecida.

Brenner (2010), opõe-se a desterritorialização ou a aniquilação do espaço pelo tempo, definindo reterritorialização como um processo de reconfiguração e reescalonamento de formas tradicionais de organização territorial, inerentes à globalização, e definidos por uma acelerada circulação de pessoas, mercadorias e capitais, no espaço global.

É unicamente por meio da construção de infraestruturas de transporte, comunicações e de regulamentação institucional relativamente fixas e móveis que esse acelerado movimento físico das mercadorias através do espaço pode ser obtido [...]. As cidades territorializam o capital pela aglomeração de infraestruturas relativamente fixas e móveis, como sistema de transporte, suprimento de energia, rede de comunicação e outras externalidades que sustentam formas específicas históricas de produção, troca, distribuição e consumo (BRENNER, 2010, p. 538-539).

Para Soja (2013), a era da metrópole moderna chegara ao fim. O autor aponta uma transição da urbanização metropolitana para a regional, e diante dessa transição pósmetropolitana, afirma que novos termos como cidades-região e cidades regionais crescerão em importância para a análise geográfica urbana ao longo da próxima década.

Brenner (2015), sugere questionamentos sobre a era urbana do nosso planeta e sobre a noção da divisão urbano/rural. Cada país mensura através de seu Censo o que é o "urbano" em formas e com variáveis distintas.

Além disso, diferentes condições de urbanização precisam ser compreendidas, evitandose, por exemplo, que as favelas de Mumbai e os subúrbios de Melbourne, sejam considerados em uma única contagem urbana sem diferenciar suas reais condições, ou , que áreas rurais na Índia, densamente povoadas, não sejam contempladas nesta contagem.

Denominadas pelo autor de paisagem operacional, áreas rurais ou lugares remotos (Ártico, Sibéria, Himalaia, deserto do Saara e de Gobi), têm se tornado consideravelmente funcionais para o processo de urbanização extensiva, pois sustentam o crescimento ou as necessidades de abastecimento dos centros urbanos, e portanto requererem estudos, “[...] é preciso gerar uma infraestrutura fixa capaz de sustentar toda a dinamicidade desse fluxo [...].Urbanização se trata de construir um cenário que sustente a produção e a circulação de capital "( BRENNER, 2015,p.). 
Para o autor, é indispensável analisar a conexão entre capitalismo e urbanização que gera massivas desigualdades sociais e degradação ambiental, além da perda de controle das pessoas sobre as condições que realmente governam suas vidas cotidianas. Como desafio necessitamos de formas de gestão diferenciadas para cada região e instituições capazes de promover uma influência coletiva sobre os ambientes construídos.

Também Lencioni (2015), chama atenção para a dissolução do termo cidade e ascensão das mega-regiões. As discussões atuais sobre aglomerações difusas, megalópole, metápolis, cidade-região, consideram esses espaços como região urbana e não como área urbana ou metropolitana. Para que uma área se constitua como uma região é necessário haver integração entre as partes.

A integração é que dá coesão ao que se apresenta disperso, para que se constitua uma totalidade, uma unidade, ou uma região. Essa integração não é definida pela continuidade de elementos espaciais, mas pela integração que apresentam. Por isso, uma região pode apresentar descontinuidade territorial dos fenômenos desde que haja integração de diversas dinâmicas e processos que se desenvolvem em seu interior.

Sem a integração não seria possível visualizar os limites da dispersão e nem capturar as relações que são estabelecidas entre os fragmentos. É a integração que permite entender a tensão entre fragmentação e totalidade e que permite compreender que a dispersão significa dispersão de partes de um todo (LENCIONI, 2015, p.9).

Portanto para a autora, as nebulosas urbanas - urbanização dispersa cada vez mais extensiva territorialmente, apresentam sim limites e coesão espacial. É na identificação dessas partes que constituem uma unidade, ou totalidade territorial, ou uma região, que devemos nos ater.

Conforme IBGE (2016), a ideia de coesão e integração se relaciona com processos sociais e/ou econômicos e, seu entendimento é fundamental para caracterizar o grau de interações que os novos arranjos urbanos estabelecem-no território. Os movimentos pendulares, fluxos de deslocamentos entre residência e trabalho ou estudo, são cada vez mais utilizados para esse fim. Cabe lembrar que estar integrado por movimentos pendulares se difere de estar integrado funcionalmente com outras dimensões. Além disso, aspectos morfológicos como a continuidade ou não de tecidos urbanos também ajudam a definir novas interações espaciais.

Ou seja, no Brasil dois critérios são utilizados pelo IBGE na identificação de novos arranjos urbanos. Um, refere-se à noção de integração medida através da intensidade dos 
movimentos pendulares, que deve ter um fluxo superior a 10.000 pessoas ou possuir um índice de integração igual ou superior 0,17 , conforme fórmula padrão. O outro se refere à noção de contiguidade entre machas urbana, ou seja, quando a distância entre as bordas de duas manchas urbanizadas não ultrapassar 3km (IBGE, 2014).

Tendo em vista essa bibliografia recente e, baseada em levantamentos empíricos, a pesquisa observa que no final do século $\mathrm{XX}$, áreas com economia avançada apresentam intensificação das dinâmicas de dispersão urbana, que por sua vez produzem maior integração e contiguidade entre manchas urbanas, definindo novos arranjos, ou novos territórios metropolitanos.

A produção intensa de usos ligados à economia moderna tem gerado a perda gradual da principal característica morfológica que identifica no território as dinâmicas de dispersão urbana que é o esgarçamento ou a descontinuidade do seu tecido urbano.

Esse nova morfologia urbana que aos poucos se manifesta é decorrente dos avanços da restruturação produtiva, ou do contínuo processo de transformação da economia capitalista, que busca constantemente garantir a manutenção da acumulação do capital.

Avançamos da universalização dos mercados e dos modos de produção que levou a dispersão e fragmentação industrial e a extensão das regiões metropolitanas, para a universalização dos modos de consumo padronizados que tem fortalecido o setor terciário em centralidades de menor porte e garantido a possibilidade real de residir distante dos grandes centros metropolitanos.

Dentre as ocupações ligadas à economia contemporânea, além da busca constante de novas fronteiras imobiliárias, ou seja, do incremento da atuação do mercado imobiliário que cada vez mais distribui pelo território produtos padronizados como os condomínios residenciais fechados, observa-se a intensificação de ocupações ligadas à modernização do terciário: shopping, hipermercados, locais de evento, malls, centros empresariais, condomínios industriais e logísticos, escolas, universidades e grandes cadeias comerciais que passam também a se organizar em rede, algumas com alcance global.

Além disso, a mecanização da agricultura e pecuária, que já permite a produção sem grandes extensões territoriais, também passa a se localizar dentro das áreas urbanas.

Esses novos usos modernos vem promovendo uma ocupação acelerada dos espaços intersticiais resultantes das dinâmicas anteriores de dispersão urbana, e portanto, a junção ou aproximação de territórios dispersos. Como resultado deste processo 
manifesta-se um tecido urbano cada vez mais contínuo, porém ainda fragmentado, ou seja, sem relação com seu próprio entorno ou com núcleos urbanos contíguos.

Portanto, decorrente dos avanços da economia capitalista, evidencia se a partir do século $X X I$, uma nova configuração morfológica do tecido urbano, que se diferencia tanto da continuidade espacial produzida em áreas urbanas que se expandem de forma tradicional, a partir de um núcleo ou centro metropolitano, como da descontinuidade territorial e espacial encontrada inicialmente em tecidos urbanos impactados pelas dinâmicas de dispersão urbana.

Essa nova morfologia urbana, cuja continuidade territorial não se originou a partir da expansão de um núcleo ou centro, mas se constituiu a partir da integração física de áreas dispersas que, em sua maioria, não se relacionam na escala local, pressupõe, portanto, a permanência das mesmas condições de fragmentação territorial encontrada na organização espacial dos territórios dispersos ou territorialmente descontínuos. Ou seja, são tecidos que embora apresentem continuidade territorial são espacialmente fragmentados, conectam-se a distância, mas não com a proximidade.

Conforme Spósito (2007), o conceito de descontinuidade ou continuidade territorial se difere do conceito de continuidade ou descontinuidade espacial. Muitas vezes a descontinuidade do território só é possível porque existe continuidade ou integração espacial, o que produz um território fragmentado, que só se viabiliza devido à existência de infraestruturas de saneamento e transporte, e principalmente pelas tecnologias de comunicação, que permitem conexões que ultrapassam os limites físicos territoriais, mas não garantem que as relações de entorno, bairro e núcleo contíguos se estabeleçam.

Parece certo que formas mais avançadas de urbanização se manifestam em áreas com localização estratégica, atendidas por infraestruturas de transporte e comunicação que atraem o desenvolvimento de uma economia mais avançada que, por sua vez, requer facilidade e agilidade de conexões e deslocamentos que garantam integração espacial. Ou seja, as transformações contemporâneas na forma urbana estão intimamente relacionadas com a alteração e avanços nas técnicas de comunicação e mobilidade.

A intensificação das ocupações dispersas ou das formas mais avançadas de urbanização, decorrente de transformações econômicas e avanços técnicos, altera e estende a escala das relações sociais, produzindo interações sociais que vão muito além das relações citadinas ou metropolitanas, provocando uma regionalização do cotidiano que acompanha a dispersão das atividades industriais modernas, do lazer, do comércio, dos serviços avançados e dos empreendimentos imobiliários (REIS, 2006). 
Além disso, a intensificação de dinâmicas de dispersão mais avançadas, que preenchem e adensam vazios urbanos, acarreta um processo de aglutinação de um todo disperso que se torna mais coeso, que assume uma forma mais nítida e revela um novo território metropolitano que extrapola limites administrativos e sobrepõem diferentes etapas do seu processo de ocupação territorial.

Segundo a análise de Indovina (2004), a diferença entre a cidade difusa (transformação urbana na região do Vêneto devido ao avanço das áreas urbanas sobre as rurais) e a área metropolitana está em suas hierarquias. A área metropolitana se estende por um território fortemente hierarquizado, um centro (a grande cidade) e suas cidades satélites pequenas e médias (difusas no território circundante), ou seja, um território caracterizado principalmente por conexões verticais, onde as ofertas urbanas (localização das atividades, deslocamento da população e outros) são centralizadas, e mais excludentes.

Já a cidade difusa, segundo a visão de Indovina (2004), pressupõe uma organização espacial caracterizada por conexões horizontais menos hierarquizadas que a área metropolitana, com formação de novas centralidades, apesar de gerar problemas do ponto de vista de degradação ambiental, de extensão da rede de infraestrutura e de fragmentação do território.

Para Secchi (2009), a cidade difusa, denominada também pelo autor de cidade porosa e permeável é uma cidade que contrasta a formação de enclaves de qualquer natureza e que portanto contrapõe a figura de isotropia com a de hierarquia.

Avançando nessa discussão, esta pesquisa atenta para os novos territórios metropolitanos que se inserem em um estágio mais avançado do seu processo de urbanização, o qual gera o fortalecimento de uma organização espacial policêntrica, e já abastecida por redes de infraestruturas.

Esse território apresenta uma articulação hierárquica urbana mais equilibrada, ou seja, os grandes centros urbanos terão cada vez menos influência sobre as médias e pequenas cidades inseridas neste contexto.

Estas, devido à intensificação e complexidade de suas relações econômicas e sociais, se tornam cada vez mais autônomas e insubordinadas a uma única e exclusiva centralidade tradicional. Contudo, apesar deste processo promover o incremento dos fluxos multidirecionais, a pesquisa atenta para a possibilidade de alteração na intensidade desses fluxos, que se relacionam com mais de uma centralidade. 
Conforme exposto, do ponto de vista da escala local ou do tecido urbano, evidencia-se a perda gradual da principal característica das dinâmicas de dispersão, que é o esgarçamento do tecido urbano. Do ponto de vista da escala regional, o adensamento de usos ligados ao avanço da economia moderna, cada vez mais fortalecem centralidades, escalas ampliadas e relações macro metropolitanas, constituindo os novos territórios metropolitanos, com possível alteração da dinâmica e intensidade de seus fluxos.

A partir deste século, além de alteração morfológica, territórios estrategicamente localizados que se inserem no padrão de urbanização avançado ou de intensificação das dinâmicas de dispersão urbana, replicam atividades e novos usos até então exclusivos dos grandes centros metropolitanos. Esta dinâmica tende a amenizar deslocamentos mais distantes para lazer, consumo e trabalho em centros metropolitanos consolidados.

Além disso, relação de importância que se estabelece entre deslocamentos físicos e as conexões virtuais tende muito gradualmente a se aproximar de um equilíbrio, ou seja, talvez em um futuro próximo, possamos observar uma inflexão nas dinâmicas de mobilidade urbana física. Conforme Domingues (2007), a rodovia criada para aumentar a velocidade dos deslocamentos, atualmente produz atritos por congestionamentos.

Do ponto de vista do deslocamento da produção, as infraestruturas físicas continuam estruturando e sendo imprescindíveis para a movimentação de produtos e mercadorias, porém do ponto de vista do consumo e do trabalho, as tecnologias de comunicação são cada vez mais assimiladas e vem aos poucos substituindo os deslocamentos físicos.

Por enquanto, observa-se que, a medida em que, novas tecnologias vão sendo incorporadas à sociedade e à produção, aceleram a transformação das relações sociais que passam a ocorrer em escala global, através do aumento dos fluxos de deslocamentos diversificados, multidirecionais e virtuais, expandindo e tornando cada vez mais complexo o entendimento das novas dinâmicas urbanas.

Castells (1999), defende que com a tecnologia da informação, facilitando as relações sociais e de trabalho, e permitindo o intercâmbio de informações em tempo real, sem a necessidade da proximidade física dos grandes centros de negócios, serviços e lazer, estabelece uma nova lógica espacial, sem forma definida, e que se viabiliza tendo como principal característica ou estrutura, o espaço dos fluxos.

O que a pesquisa sugere é que as formas mais avançadas de urbanização em processo de modelação, sejam estas indefinidas, dispersas, descontínuas, difusas, ou coesas, vem apresentando contornos e limites territoriais mais nítidos, com fluxos multidirecionais intensos, e permanência de relações espaciais ainda bastante complexas. 
O que permanece, tanto nas dinâmicas de dispersão urbana como nas formas mais avançadas de urbanização, é que ambas estimulam a produção de um espaço urbano conectado muito além da proximidade física, embora cada vez mais diferenciado em termos sociais, ou seja, cada vez mais territorialmente segregado.

Barreiras físicas e sistemas de segurança mantem distantes diferentes classes sociais. A abertura de Infraestrutura, bem como, áreas públicas e institucionais dos novos condomínios não são estendidas para as áreas adjacentes ocupadas por população de mais baixa renda.

Embora esses novos espaços estejam conectados a redes globais, são internamente desconectadas das populações locais, o que caracteriza a produção de uma nova dimensão urbana. Há coisas próximas que não se tocam, há coisas longíguas que se relacionam. Há relações que não se reproduzem no interior de um determinado espaço. (DOMINGUES 2007, pg 230).

Diante do exposto, a questão que se coloca, frente a essas alterações morfológicas e de mobilidade, é se a partir do século XXI, ainda podemos falar em dispersão urbana como expressão espacial decorrente da intensificação e evolução do processo de reestruturação produtiva.

A forte atuação do mercado imobiliário, a modernização da indústria, o crescimento do número, tamanho, importância, poder e integração das grandes cadeias do setor de serviço, bem como, os complexos agroindustriais, ou seja, o avanço da exploração de todas as possibilidades de produção e consumo em escala global, tem alterado a lógica territorial e espacial.

Portanto, os processos de dispersão urbana devem ser entendidos como um estágio ou, uma dinâmica temporária, que faz parte de um processo mais amplo que vem levando a outras formas mais avançada de urbanização constituindo novos territórios metropolitanos que requerem entendimento e gestão integrada.

O que se conclui é que, partir de 2000, inicia-se a configuração de um novo estágio de produção do espaço capitalista, decorrente da intensificação dos processos de reestruturação produtiva, da globalização e da intensa incorporação das telecomunicações pela sociedade e pela produção.

Dinâmicas de urbanização avançada configuram novos territórios metropolitanos que tem como principal característica morfológica a continuidade territorial em contraposição a 
descontinuidade dos tecidos urbanos dispersos, embora, ambos processos ainda apresentem fragmentação territorial.

Conforme Domingues (2007), necessitamos encontrar novas formas para denominarmos as novas coisas, evitando levar ao limite o processo de reciclagem de conceitos que vem de um momento anterior e pertencem a um mundo diferente. O problema nós já identificamos, agora é preciso criar consensos nas diferentes esferas do poder público sobre hierarquias de decisões, na tentativa de compreender as novas questões advindas desse processo.

Considerando esse território metropolitano, contínuo e fragmentado, que prevalece na contemporaneidade, uma questão que se observa é que a intensificação das dinâmicas de dispersão urbana continua a negar e a ultrapassar os limites municipais estabelecidos.

Como gerir o que é público e deve ser partilhado por muitos, como obter consensos entre os reais usuários de formas mais avançadas de urbanização, onde a nova lógica dos espaços de fluxos, faz com que a sociedade se relacione em múltiplas dimensões que vão muito além dos imites administrativo estabelecidos, ao mesmo tempo, em que não se relaciona com o espaço físico que ocupa ou com seu entorno local.

A partir do exposto, e tendo em vista o vetor noroeste paulista, observa-se a partir de 2000, devido aos avanços da economia capitalista ou à intensificação das dinâmicas de reestruturação produtiva, a produção de novas formas de tecido urbano neste vetor, que começam a assumir características morfológicas, distintas daquelas apresentadas pelas tradicionais dinâmicas de dispersão urbana.

A seguir, no capítulo II, a pesquisa atenta para a evolução histórica do vetor noroeste paulista, com o objetivo de melhor compreender as diferentes etapas de seu processo de urbanização, ou de sobreposições de temporalidades históricas fragmentadas, bem como, as recentes transformações em suas dinâmicas de dispersão urbana. 
CAPÍTULO 2

\section{Evolução Espacial: Das Vilas aos Novos Territórios Metropolitanos.}

Aborda-se aqui a evolução histórica e as transformações recentes nas dinâmicas urbanas e econômicas do vetor noroeste paulista (industrialização, desconcentração industrial, dispersão urbana e urbanização avançada), possibilitadas pela evolução técnica de sua rede de infraestrutura, estrategicamente prevista para atender determinados ciclos produtivos, que demandou novos padrões de mobilidade, que por sua vez, permitiu a transformação das antigas vilas em novos Territórios Metropolitanos. 


\subsection{Temporalidades Históricas: Vetor Noroeste: Eixo São Paulo - Campinas.}

A busca constante do capitalismo por novos mercados e fluidez de mercadorias, refletiuse no contínuo processo de evolução do vetor noroeste da capital paulista, eixo São Paulo - Campinas, atualmente um importante corredor econômico do país.

Esse vetor se desenvolve apoiado no progresso técnico e estratégico de sua rede de infraestrutura fixa, que lhe garante suporte espacial para maior fluidez e mobilidade de pessoas e riquezas, configurando aos poucos uma nova dimensão espacial (EIGENHEER, 2011).

Ao mesmo tempo, diferentes ciclos produtivos, mineração, agricultura, industrialização, desconcentração industrial, reestruturação produtiva, aliados ao avanço de sua infraestrutura de transporte, foram definindo novos padrões de ocupação neste vetor.

As antigas trilhas dos indígenas no século XVIII, depois os caminhos de tropas, então a ferrovia paulista no século XIX, a primeira rodovia precária em 1922, e finalmente 0 moderno e atual sistema de rodovias implantado a partir da segunda metade do século XX, estruturaram o desenvolvimento e a evolução urbana do vetor Noroeste.

Desde o século XVIII, esse eixo tem como principal função o transporte das riquezas entre o próspero interior, a capital e o porto de Santos, transformando-se no maior eixo econômico do país. Atualmente é constituído pelo sistema de rodovias Anhanguera/ Bandeirantes que estrutura as relações territoriais contemporâneas que se estabelecem entre as regiões metropolitanas de Campinas e de São Paulo.

No ciclo do ouro, pelo caminho aberto pelos indígenas (Caminho dos Goiazes), Bartolomeu Bueno da Silva, conhecido como Anhanguera, partiu em 1722 de Jundiaí rumo a Goiás, à procura de ouro. Denominou a antiga trilha indígena de "Caminho do Anhanguera", de onde nasceram alguns pousos e vilas, para dar apoio às tropas e viajantes, como Jundiaí, e depois Campinas (REIS, 2014).

Durante a primeira metade do século XVIII, a colonização dessa região ocorreu ao longo das antigas trilhas, sem muito se distanciar de seu eixo. Para além das trilhas apenas tribos hostis ou grandes vazios desabitados eram encontrados (Reis, 2014).

No ciclo agrícola, temos a importância da cultura cafeeira que se inicia no último quartel do século XIX, que tem a ferrovia como principal infraestrutura para o escoamento da produção. O sucesso econômico da região levou a expansão urbana e o desenvolvimento das vilas e cidades, e a estruturação urbana da capital de São Paulo e do oeste paulista. 
Em 1867, os ingleses inauguram a primeira ferrovia no país, a Estrada de Ferro de Santos - Jundiaí ou São Paulo Railway Company, na época, um dos negócios mais rentáveis do país devido ao intenso fluxo de produção. Estabelece-se a primeira conexão ferroviária entre o planalto paulista e o litoral. Devido à complexidade desta obra, não houve interesse dos ingleses em seu prolongamento para além de Jundiaí.

Tendo em vista as riquezas da economia cafeeira do oeste, empresários paulistas decidem estender a ferrovia até Campinas. A partir de 1868, a Companhia Paulista de Estrada de Ferro passa a conectar Jundiaí a Campinas, iniciando-se o ciclo ferroviário com capital regional, e estruturando o desenvolvimento urbano de Campinas, intensificado devido a sua conexão com a capital paulista.

Com a implantação da ferrovia; o fim do trabalho escravo 1888; a chegada dos imigrantes 1891, e o estabelecimento de novas relações de trabalho, inicia-se o processo de transição industrial e de urbanização dessa região.

Conforme Reis (2014), o traçado da ferrovia seguiu em alguns trechos as diretrizes gerais dos antigos caminhos de tropas, valorizando as novas áreas que passaram a servir e desvalorizando as antigas estradas de terra, que em alguns trechos foram desviadas e abandonadas servindo apenas à passagem de boiadas.

Jundiaí se torna um dos únicos aglomerados nos arredores paulistanos servido pela ferrovia, o que acarreta seu desenvolvimento. Com a extensão da ferrovia para Campinas, passa a concentrar importantes oficinas da "Companhia Paulista", que promoveram seu desenvolvimento industrial, apoiado no capital local e na agricultura comercial da área.

A seguir, Campinas se torna um dos maiores entroncamentos ferroviários do estado, devido a sua posição estratégica e a ampliação da ferrovia Paulista para o interior. Outros importantes trilhos surgem conectando a cidade com o sul de Minas Gerais (Mogiana 1872) e com o interior do estado e Mato Grosso do Sul (Paulista e Sorocabanade -1921), além de mais dois trilhos menores, para Paulínia (Funilense - 1890) e para Sousas (Ramal Férreo -1889).

Até 1880, Campinas e São Paulo possuíam o mesmo número de habitantes e rivalizavam a centralização das atividades urbanas da economia cafeeira. A partir de 1886, a capital paulista consolida-se como "metrópole do café", ocorre um grande surto de crescimento da sua população que ultrapassa a de Campinas, e que se mantém até hoje. (LANGEMBUCH,1971). 
As estações das ferrovias deram origem a povoados que se desenvolveram ao longo dos eixos ferroviários, e que se transformaram em importantes núcleos suburbanos. Enfim, as ferrovias foram essenciais para uma nova reorganização territorial e para o colapso das antigas trilhas e estradas de terra. (LANGEMBUCH, 1971).

O vetor noroeste da capital, nas margens da ferrovia Santos-Jundiaí, tem nesse momento um desenvolvimento industrial e suburbano modesto, inexpressivo se comparado com o que ocorreu na mesma estrada de ferro, no sentido Santos, onde verifica-se um pouco a seguir, a fusão de São Caetano com Santo André.

Embora de grande importância para estruturação desse território, a partir de 1920, iniciase o declínio do sistema ferroviário. Ao longo do século XX as ferrovias são desativadas e substituídas gradualmente por uma moderna rede rodoviária. O processo de industrialização do Brasil demandava uma maior integração territorial, através de uma rede transporte que articulasse todo o território nacional.

Já no início do século $X X$, um dos problemas no estado de São Paulo era a conexão precária da capital com Jundiaí, através da ferrovia e da estrada da boiada com carros e tropas. Entre 1915 e 1921, essa dificuldade demandou a construção por detentos de uma nova estrada : a Estrada Velha de Campinas.

Aproximadamente 200 anos da rota traçada pelo bandeirante Anhanguera, construiu-se a Estrada Velha de Campinas que, apesar da péssima condição técnica, não pavimentada e com pista única, tornou-se, na época, o primeiro e principal tronco viário do estado de São Paulo, conectando a capital ao interior do oeste paulista.

Atualmente denonimada SP-332, e também conhecida como estrada da boiada, seu traçado em alguns trechos pode ter sido originado a partir do percurso aberto por Bartolomeu Bueno da Silva, o Anhanguera, a partir de 1722, e que fora abandonado devido ao advento ferroviário.

Alguns fatores levaram a intensificação do processo de industrialização e urbanização do vetor noroeste. A queda da produção cafeeira, a crise financeira internacional relacionada à queda da bolsa em 1929, a necessidade de diversificação da produção, e a revolução de 1930, acarretaram um novo padrão de acumulação baseado no capital industrial.

De 1930 a 1950 ocorreu a transição da economia essencialmente agrária para a industrial, ao mesmo tempo em que a circulação rodoviária assumiu um papel crescente na expansão urbana da capital e na decadência do sistema ferroviário. 
Até então, a conexão da capital com as riquezas do oeste paulista se fazia pela Estrada Velha (1924), que devido a sua precariedade, demandou alterações no padrão de mobilidade vigente, devido ao início da industrialização após 1930 e a intensificação das relações entre a capital e o próspero interior.

Em 1940, o governo do estado preocupado com as condições técnicas da conexão entre a capital e o próspero oeste paulista, e diante da necessidade da modernização viária no trecho compreendido entre São Paulo e Jundiaí, tendo em vista o início do processo de industrialização do país, determinou, a construção da Via Anhanguera (SP-50).

Cabe lembrar que, tendo em vista as riquezas do interior e o tráfego extra regional de São Paulo, uma necessidade percebida já há algum tempo, a primeira auto-estrada a ser entregue foi a Via Anchieta (SP-150), em 1947, e a seguir o tão esperado primeiro trecho da Via Anhanguera, em 1948, inicialmente dirigida somente até Jundiaí e administrada por uma empresa estatal o DER.

Com relação as novas localizações industriais, as autoestradas aos poucos substituem o importante papel desempenhado pelas ferrovias. O desenvolvimento suburbano da capital se estruturou no desenvolvimento das ferrovias, porém evoluiu se apoiando nas estradas convencionais que junto com as autoestradas, surgidas em fins da década de 40, assumem um papel fundamental na metropolização dos arredores paulistanos.

A propagação da cultura do capital americano, do automóvel e do arranha-céu, manifestase espacialmente em detrimento da tendência europeia defendida pela burguesia cafeeira, alterando o modo e vida e as relações sociais.

A Via Anhanguera, junto com a Via Anchieta, estabeleceriam a primeira ligação rodoviária do interior do estado ao porto de Santos, um dos mais importantes da América do Sul na época. A partir de1950, a evolução técnica e estratégica da rede rodoviária paulista, serviria de base espacial para estruturar as quatro etapas seguintes do processo de acumulação capitalista no Brasil: industrialização, desconcentração industrial, reestruturação produtiva e avanços da economia moderna.

Conforme veremos a seguir, a evolução desses processos produtivos impactou na produção de relações sociais e formas urbanas estendidas, bem como, na morfologia e nas dinâmicas urbanas do vetor noroeste paulista. 


\subsection{Industrialização e a formação da "Grande São Paulo".}

No contexto mundial, temos o pós-guerra, a partir de 1945, e diante deste quadro um novo cenário de relações produtivas e de consumo no mundo. A economia capitalista passa por transformações econômicas sem precedentes com impactos na vida cotidiana.

No Brasil, o intenso processo de industrialização, com forte presença das multinacionais e indústrias automobilísticas, estimulou as migrações, sobretudo para as cidades, acelerando o ritmo da urbanização. Além da mudança do padrão de acumulação de capital, investimentos em infraestrutura rodoviária promoveram a integração do mercado nacional.

Em 1950, a Via Anhanguera é prolongada mais $37 \mathrm{~km}$, estendendo-se de Jundiaí para Campinas e alguns anos depois para o Norte do Estado. Seu segundo trecho, entre Jundiaí e Campinas, passou a conectar a metrópole que se consolidava ao município de Campinas. A segunda pista do trecho São Paulo-Jundiaí, foi inaugurada em1953.

Por sua posição geográfica, a via Anhanguera desempenharia papel relevante na circulação da riqueza agrícola e industrial do Estado de São Paulo, transportando grande parte da produção do interior para a capital, considerada uma das cidades de crescimento mais rápido do mundo e que devido a sua localização funcionava como centro de convergência da produção do estado como também de estados vizinhos.

Em 1951 inaugura-se a rodovia federal Presidente Dutra (BR-116 ou SP-060), melhorando sensivelmente a ligação de São Paulo com o Rio, beneficiando as cidades do Vale do Paraíba e completando o trio de auto-estradas que daria suporte espacial a industrialização pesada a partir da segunda metade do século XX no país.

Nesta década, São Paulo manteve sua hegemonia econômica através da implantação da industrialização pesada na região metropolitana, com ênfase para o $A B C$, impulsionada pelos novos eixos produtivos rodoviários. Com o Plano de Metas em 1956, e o forte apoio do governo e investimentos estrangeiros, consolidou-se a metropolização da capital.

Das três primeiras auto-estradas que irradiavam de São Paulo, a Via Anchieta ( 1947) e a Via Dutra (1951) foram as que impulsionaram de modo mais significativo o desenvolvimento industrial e suburbano de suas áreas lindeiras.

A primeira, afetando o município de São Bernardo do Campo (e todo o $A B C D$ ), e a segunda o município de Guarulhos, que assistem a oferta de novas oportunidades de atração industrial em função da melhor condição de conexão com a metrópole, assim como o surgimento de núcleos residenciais nas margens das rodovias. Entre 1950 e 
1960, esses municípios conheceram um desenvolvimento industrial que superou o da capital e dos antigos subúrbios de São Caetano e Santo André (LANGENBUCH, 1971).

A ausência de condições topográficas favoráveis e de uma rentável ocupação de uso do solo, que não ocupasse grandes extensões territoriais, fez com que naquele momento a especulação imobiliária não despertasse o interesse para o vetor noroeste, ficando para as décadas seguintes, a ocupação, o desenvolvimento e a valorização desse vetor.

Entretanto, na região de Campinas, a rodovia Anhanguera, por não apresentar dificuldades topográficas, desde cedo é o primeiro eixo rodoviário a estruturar o desenvolvimento industrial e a expansão urbana da cidade.

Como dito, a Via Anhanguera é a que menos impulsionou a expansão metropolitana nos arredores de São Paulo. A região de Perus, Caieiras e Cajamar, foi ocupada pela agroindústria, com pinheirais e eucaliptais pertencentes à plantações da fábrica de papel "Melhoramentos", conhecida pelo reflorestamento de eucaliptos para produção de papel que ocupavam grande parte dessa paisagem.

Do ponto de vista do uso e ocupação do solo, até 1950, são as áreas rurais e a agroindústria que predominam. Ou seja, indústrias leves de bens de consumo associadas a recursos naturais e empregadora de numerosa e não qualificada mão de obra como, Frigorífico Amour, Melhoramentos, Cimento Portland, Companhia Swift do Brasil, Hudson de óleos lubrificantes dentre outras, que predominam e se desenvolvem sobre esse eixo.

Além disso, áreas florestais, protegidas e tombadas, como a Reserva Florestal do Jaraguá localizada no início das rodovias Anhanguera e Bandeirantes, e a Serra do Japi em Jundiaí, dificultaram a ocupação industrial no começo do vetor noroeste paulista.

Do ponto de vista espacial, o incremento do sistema rodoviário e das primeiras autoestradas, gerou uma ocupação urbana e industrial mais pulverizada ao longo dos trajetos das rodovias e das autoestradas, em detrimento das ocupações anteriormente polarizadas pelas estações ferroviárias.

Esse processo contribui para a intensificação do desenvolvimento suburbano e metropolitano da capital e para o início do processo de dispersão urbana e industrial.

Conforme Reis (2006), a partir da década de 1970, acelerou-se o processo de interiorização da atividade econômica, ou, de desconcentração da atividade industrial da metrópole paulista rumo ao interior e outros estados, como veremos, com impactos relevantes na forma e no lugar onde as novas indústrias viriam a se concentrar. 


\subsection{Desconcentração Industrial e Áreas Metropolitanas.}

No contexto mundial, observa-se a partir de 1973, a crise mundial do petróleo e a necessidade de modernização da indústria nacional. Diante deste quadro, aliado a políticas públicas internas e à expansão da malha rodoviária, inicia-se o processo de desconcentração da atividade industrial da capital paulista.

Esse processo foi incentivado principalmente pelos Planos Nacionais de Desenvolvimento (PND I e II), que direcionavam recursos para regiões periféricas, e também pelos planos estaduais, que passaram a privilegiar cidades médias do interior. É nesse momento que entra em ascensão o vetor noroeste paulista.

Cidades médias do interior, como Campinas, passam a ser privilegiadas, em detrimento da Capital e da RMSP. Surgem novos eixos rodoviários, como a rodovia dos Bandeirantes, para dar suporte espacial à desconcentração produtiva da capital. Advindo deste processo novas regiões metropolitanas se consolidam.

Com o início desse processo de interiorização do desenvolvimento, aos poucos, a Via Anhanguera se tornou saturada, o que demandou a construção de uma nova rodovia.

Em 1978, a via Anhanguera é complementada pela rodovia dos Bandeirantes (SP-348), uma autoestrada fechada, gerenciada pela DERSA Desenvolvimento Rodoviário S.A, uma empresa de economia mista, instituída em 1969.

A nova rodovia estabeleceria uma conexão mais eficiente entre a Região Metropolitana de São Paulo e o município de Campinas, absorvendo cerca de 50\% do fluxo da rodovia Anhanguera, que já se encontrava saturada na década de 1970.

Neste mesmo ano, o governo federal estabelece a legislação para as nove áreas metropolitanas no país. Investimentos estruturais são realizados a partir desta política centralizadora do governo autoritário.

A partir da década de 1970, observa-se que novos usos surgem nas faixas lindeiras da via Anhanguera. Além da nova espacialização da indústria moderna de diversificados setores e da consolidação dos primeiros bairros operários, surgem os loteamentos residenciais para lazer de fim de semana, enfim áreas de grande dinamismo que se desenvolvem ao longo do eixo da via Anhanguera, e se misturam com outras áreas remanescentes, ainda ocupadas por atividades rurais (DERSA, 1980).

De 1950 até 1990, são as indústrias de transformação, além de empresas nacionais e multinacionais no segmento de bens duráveis ( $3 \mathrm{M}$, Bosch, IBM, Mercedes, 
Siemens,P\&G, Unilever, Honda ), que se localizam nesse eixo, muitas delas em Sumaré e nos Distritos Industriais de Campinas e Jundiaí, estabelecidos na década de 1970.

Em 1976, a DERSA, empresa de economia mista criada em 1969 para projetar a rod.dos Imigrantes, é quem assume a administração da via Anhanguera e inicia os projetos para a nova rodovia que supriria as demandas de mobilidade já saturadas da via Anhanguera.

Em 1978, foi inaugurada a rodovia dos Bandeirantes, que suportaria à nova espacialização da indústria que se desloca rumo ao interior, acarretando o desenvolvimento de cidades médias como Campinas.

O plano diretor do corredor SP/Campinas, estabelecia que a rod. dos Bandeirantes, autoestrada fechada com características de via expressa, daria fluidez e segurança ao tráfego de longa distância entre SP e o norte do estado, devendo ser poupada das viagens curtas e médias. A via Anhanguera, já comprometida com acessos locais implantados a curta distância, caberia à função de dar vazão às viagens curtas e médias.

Cabe lembrar, que esse processo ocorre também em outros eixos da capital. Outras rodovias (Imigrantes e Trabalhadores) surgem para dar suporte espacial ao processo de desconcentração da indústria da capital, propiciando o desenvolvimento de outras cidades médias como Santos e São José dos Campos, que nas décadas seguintes, se transformariam também em importantes regiões metropolitanas.

Com a constituição do sistema Anhanguera /Bandeirantes, intensificam-se os fluxos e as relações entre a metrópole e o município de Campinas, relações sociais e modos de vida mais estendidos se manifestam. Além do incremento de sua função de deslocamento de pessoas e mercadorias, a via Anhanguera, passaria a ter função urbana, ou seja, as pessoas começam a residir, trabalhar e se locomover ao longo do seu eixo.

De acordo com Deák e Schiffer (2010), no estado de São Paulo a descentralização de atividades industriais a partir da metrópole, no inicio de 1970, significou uma estratégia voltada para a manutenção da hegemonia do capital paulista, possibilitando a extensão da dinâmica metropolitana industrial para uma nova escala territorial. Segundo os autores, a extensão das infraestruturas rodoviárias regionais foi fundamental para essa transição.

Segundo Negri (1996), a partir de 1970, quatro fatores colaboraram notadamente para a intensificação do processo de desconcentração produtiva: a excepcional expansão da infraestrutura viária, o segundo plano nacional de desenvolvimento, as deseconomias de aglomeração, e a industrialização do interior Paulista. 
Conforme Schiffer (1989), esse processo visava assegurar a expansão e a hegemonia do capital paulista, que até a década de 1970, foi sustentada devido à concentração industrial no ABCD paulista. Era necessário estender a implantação de infraestrutura, a fim de possibilitar um fluxo desimpedido da produção ao consumo de mercadorias.

Em decorrência, observamos o arrefecimento industrial da região metropolitana de São Paulo e uma concentração de segmentos de produção industrial no interior e em outros estados. Cidades médias se desenvolvem, novas regiões metropolitanas se consolidam, e se iniciam as primeiras dinâmicas de dispersão urbana.

A partir de 1970, observa-se a configuração de um novo arranjo espacial, com crescimento de cidades médias e formação de novas aglomerações urbanas não metropolitanas (Jundiaí, Sorocaba, Piracicaba) e metropolitanas, como Campinas, Santos e São José dos Campos.

Conforme Reis (2015), nosso quadro urbano, descrito em 1945 e 1950, ficou completamente alterado. Passam a existir não apenas duas metrópoles importantes (Rio e São Paulo), circundadas por cidades menores, mas novas aglomerações urbanas, algumas metropolitanas outras não.

Na década de 1990 se constituiu, como denominada pelo governo do Estado, a Região Metropolitana de Campinas. Conexões cada vez mais velozes e instantâneas de pessoas, mercadorias, informação e capital, ocorrem entre as R.M. de Campinas e São Paulo.

Todos esses fatores acarretaram transformações na estruturação do espaço nacional com ênfase para o interior do Estado de São Paulo. Conforme Nobre (2000), cada estágio de desenvolvimento do sistema capitalista produziu distintas formas de urbanização em diferentes localizações, na medida em que constitui uma base física material adequada aos modos de produção, circulação, troca e consumo.

A intensificação desse processo assinala uma reordenação das atividades econômicas e dos movimentos populacionais sobre o território, que se estendem além da metrópole de S.P, impactando tanto na distribuição, quanto nos deslocamentos da população no eixo Campinas-São Paulo (CANO, 1998).

Até 1990, os fluxos de deslocamento decorrentes da dispersão industrial permanecem em sua maioria, direcionados aos principais centros metropolitanos, onde as atividades do setor terciário, serviço, comércio e lazer ainda apresentavam muito maior diversidade.

Conforme veremos a seguir, a partir de 1990, a reestruturação produtiva apoiada na globalização, intensificou o processo de fragmentação e dispersão industrial e urbana. 


\subsection{Dispersão Urbana e novas centralidades.}

A partir de 1990, no contexto mundial ocorre a queda do muro de Berlim, e configura-se uma nova perspectiva de integração do mercado mundial. Com a globalização as relações de produção e consumo passam a ocorrer em escala global.

No Brasil, a reestruturação produtiva e os avanços da globalização promoveram a fragmentação da indústria, bem como a internacionalização da economia e transformações sociais que se refletem na intensificação dos processos de dispersão urbana. Relações que vão além da escala metropolitana são fortalecidas. Advindo deste processo, constitui-se no estado de São Paulo, um macro território estendido cujas dinâmicas extrapolam os limites das regiões metropolitanas estabelecidas.

A implementação de políticas neoliberais, permitiu a inserção do país na economia global e o fortalecimento do capital privado e do setor de serviços, com ênfase para o mercado imobiliário e financeiro, principais forças transformadoras das metrópoles ou regiões contemporâneas.

Esse processo de reestruturação produtiva demandou um suporte espacial adequado que permitiram que novas relações territoriais se estabelecessem. São Paulo passou a conectar-se à rede de metrópoles globais, Ao mesmo tempo, impactos territoriais significantes foram verificados no sistema Anhanguera/Bandeirantes que passou então a conectar duas regiões metropolitanas.

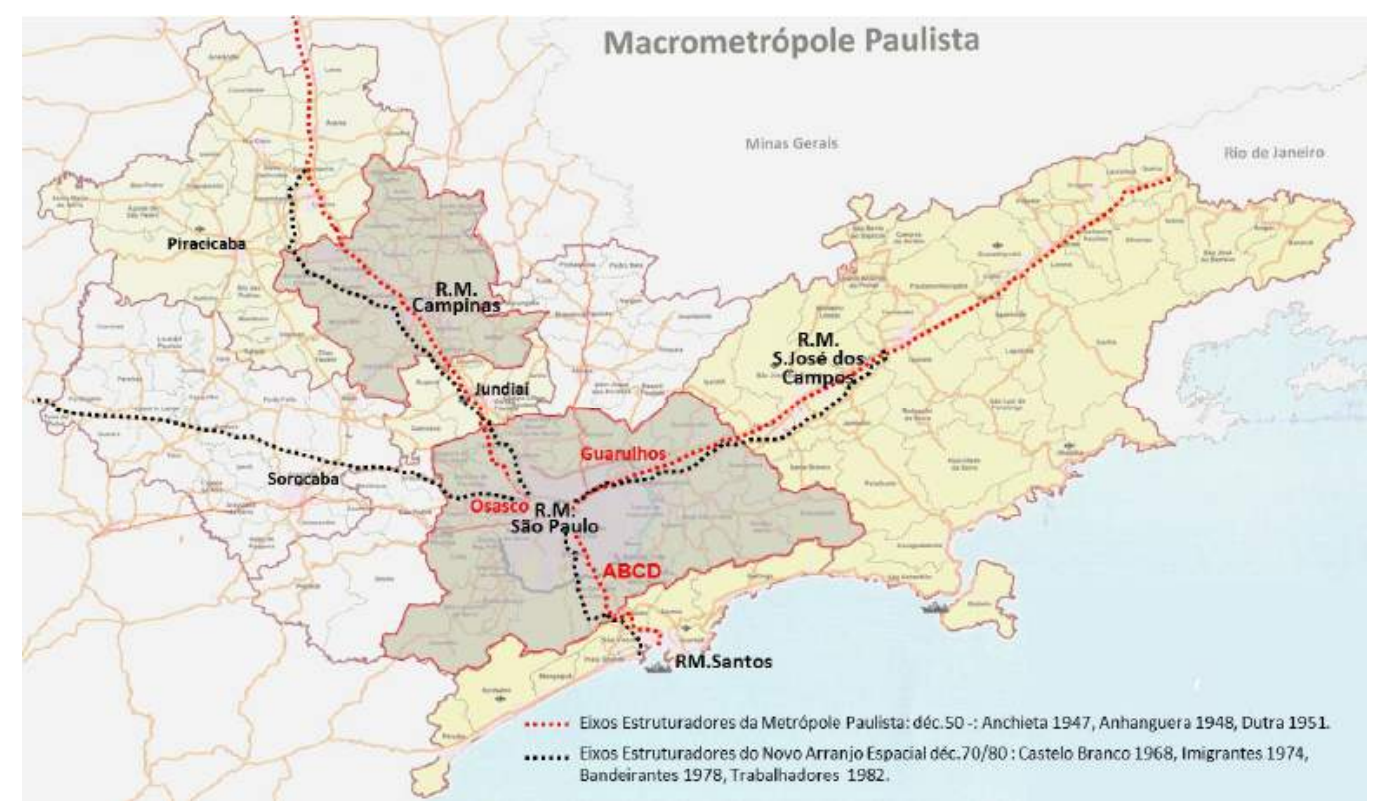

Figura 2.1: Eixos Estruturadores do quadro econômico e urbano paulista: Da metrópole a macrometrópole. Fonte: Elaborado a partir de base Emplasa - Empresa Paulista de Planejamento Metropolitano.

Cabe ressaltar a importância das novas tecnologias de informação que permitiram a modernização da indústria e maior flexibilidade nas suas localizações. A separação 
entre gestão e produção industrial acarretou fragmentação física e espacial da nova indústria moderna.

Atividades antes desenvolvidas no interior das fábricas como gestão, controle financeiro, automação de processos, seleção de pessoal, logística e distribuição, são terceirizadas e distribuídas de forma dispersa pelo território, com ênfase para os principais eixos produtivos rodoviários, impactando o vetor noroeste paulista agora estruturado pelo sistema de rodovias Anhanguera/Bandeirantes.

Decorrente deste processo de fragmentação e terceirização industrial, agora, é a nova indústria advinda do setor terciário e relacionada com a produção nacional e com exportações a nível global, de reduzida, porém, qualificada mão de obra, que se fragmenta e se dispersa pelo território, ocupando grandes áreas dispersas e de baixa densidade ao longo de todo eixo da rodovia Anhanguera.

Esse processo é acompanhado pela intensificação das dinâmicas de dispersão urbana e dos deslocamentos urbanos cotidianos que são suportados pela contínua modernização dos eixos rodoviários pós-década de 1970, e pelas novas tecnologias de comunicação, que além de permitirem a fragmentação da indústria, passam a garantir a possibilidade real de trabalhar e residir distante dos grandes centros metropolitanos.

Predominam agora na via Anhanguera os grandes centros de abastecimento e logística, além dos avançados tecnopolos, e indústrias de ponta, associados a grandes centros universitários de pesquisa e tecnologia. Além disso, observa-se a transformação dos antigos condomínios de chácaras lazer de fim de semana em condomínios residenciais, e uma intensa produção imobiliária de novos loteamentos e condomínios residenciais.

A intensificação das relações sócio-econômicas, bem como, dos deslocamentos urbanos cotidianos no sistema Anhanguera/Bandeirantes, principalmente entre a Região Metropolitana de São Paulo e a Região Metropolitana de Campinas, cria uma dinâmica uniforme que passou a caracterizar essa região do estado.

Esse desenvolvimento ocorreu também nos demais vetores de expansão da capital e embora cada um possua suas especificidades, uma dinâmica uniforme passa a caracterizar esse macro território que se estende além da Região Metropolitana de São Paulo, resultando na configuração de uma nova escala territorial.

Em 1992, a Emplasa, tendo em vista a extensão das relações sócio econômicas da metrópole paulista e para melhor gestão e desenvolvimento dessa região metropolitana estendida, denomina-a de Macrometrópole Paulista. 
Atualmente, esse complexo compreende as regiões metropolitanas de São Paulo, Campinas, Baixada Santista, Sorocaba, Vale do Paraíba e Litoral Norte, bem como as aglomerações urbanas de Jundiaí e Piracicaba e a unidade regional de Bragantina. Tem como principal eixo de desenvolvimento o vetor noroeste, estruturado pelo moderno sistema de rodovias Anhanguera-Bandeirantes.

Melhorias e modernizações no sistema Anhanguera/Bandeirantes, administrado a partir de 1998 por uma empresa privada, a CCR Autoban; o início na mesma data das obras do primeiro trecho oeste do Rodoanel; a expansão do Aeroporto de Viracopos e do Porto de Santos, viabilizaram a partir de então, a transformação do SAB em um importante corredor regional de mobilidade nacional e de intenso desenvolvimento industrial e urbano.

A Via Anhanguera passou a atrair o mercado imobiliário para novos usos ligados à economia moderna enquanto a rodovia dos Bandeirantes, autoestrada fechada, assume a função de principal vetor de mobilidade urbana do Estado.

Indústrias de tecnologia se instalam na região de Campinas ( Dell, IBM, Huawei) e Jundiaí (Foxconn, Itautec, Aoc e Mahle). Ademais uma significativa quantidade de centros terceirizados de abastecimento e logística passam a ocupar grandes áreas dispersas ao longo do eixo da rodovia Anhanguera, entre a capital e Campinas, estendendo-se a partir do século XXI também para a rodovia dos Bandeirantes.

Além dos CDs, advindo dos processos de reestruturação produtiva, verifica-se na via Anhanguera, entre São Paulo e Campinas, a presença de mais de 50 empresas com acesso direto pela rodovia. Além da indústria moderna, novos loteamentos e condomínios residenciais horizontais se multiplicam neste vetor.

Ao mesmo tempo, verifica-se o aumento de suas ocupações precárias e informais, embora estas não sejam predominantes, no mais importante vetor de desenvolvimento econômico do estado. De qualquer forma, configura-se um novo tecido heterogêneo, disperso e fragmentado, que tem como principal elemento de mobilidade urbana e eixo estruturador o sistema Anhanguera /Bandeirantes.

O resultado desse processo é o início de um processo de configuração de uma morfologia urbana mais linear, com fluxos multidirecionais e formação de novas centralidades menores, que tendem a se tornar cada vez mais autônoma e menos subordinada às aglomerações ou metrópoles tradicionais. 
A evolução das infraestruturas de transporte que estruturam o vetor noroeste paulista, foi estrategicamente prevista para atender determinados ciclos produtivos. Ou seja, elas são decorrentes de um conjunto bem mais complexo de transformações produtivas que as antecederam e que previram a sua necessidade (EIGENHEER, 2011).

Relações econômicas, apoiadas por políticas públicas, foram definindo novos padrões de mobilidade que, por sua vez, permitiram a extensão da escala da vida urbana e que formas urbanas cada vez mais estendidas se manifestassem sobre esse território, reconfigurando o espaço metropolitano.

Essa nova dimensão metropolitana, com aumento de importância das cidades médias e de novos polos de desenvolvimento, impõe um novo modo de pensar que extrapole os limites administrativos estabelecidos ou a tradicional área metropolitana institucionalizada (Lencioni 2004).

Conforme veremos a seguir, o avanço e a intensificação dos processos de reestruturação produtiva ou de modernização dos modos de produção e consumo capitalista, intensificam e alteram as relações sociais e as dinâmicas de dispersão urbana, produzindo no eixo Anhanguera novas formas de tecido urbano.
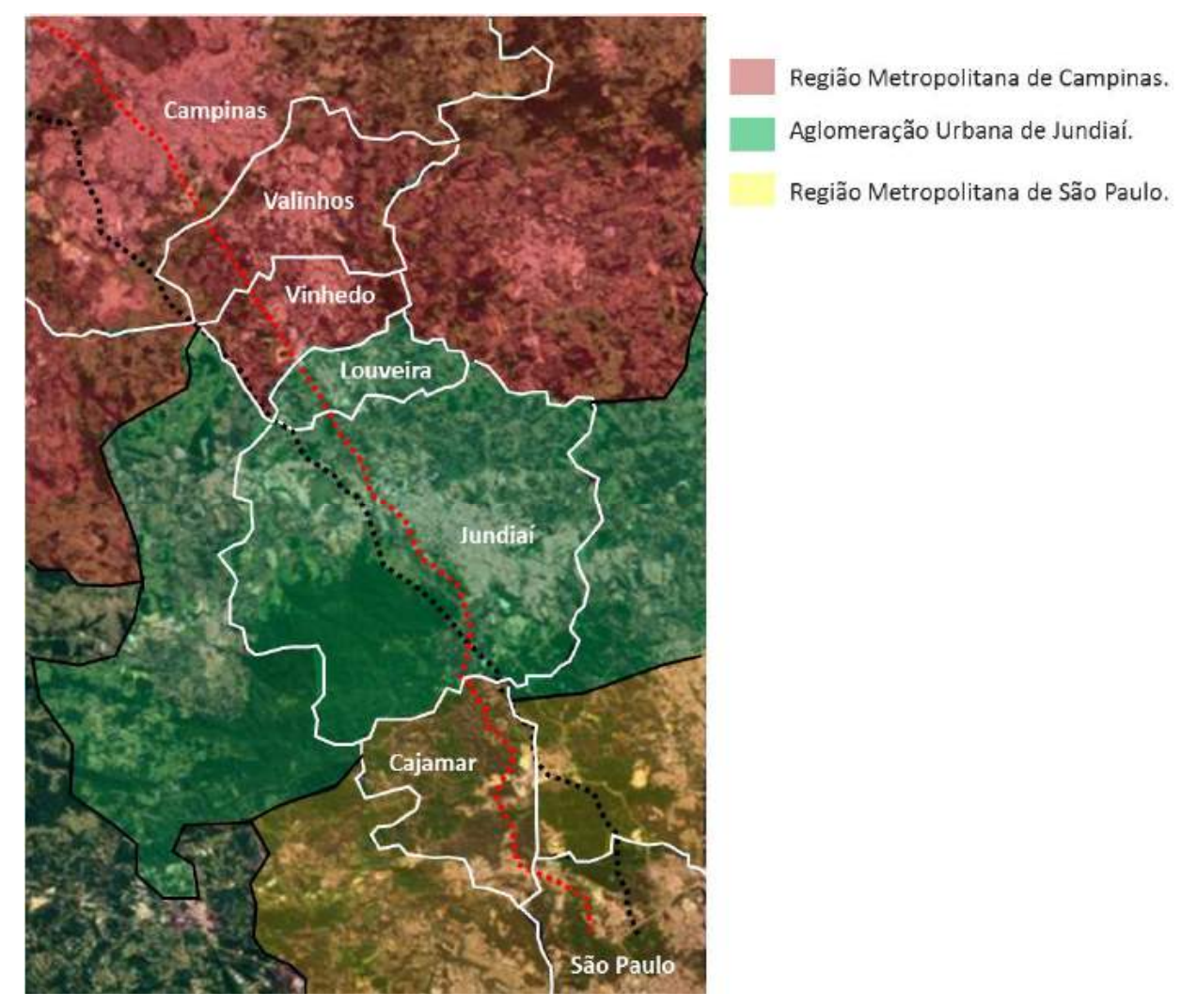

Figura 2.3: Limites administrativos dos municípios localizados no eixo Anhanguera.

Fonte: Elaborado a partir de imagens http://www.emplasageo.sp.gov.br, acessado em 20/11/2017. 


\subsection{Dispersão dos Serviços e Novos Territórios Metropolitanos.}

A partir 2000, com a tecnologia cada vez mais incorporada à produção e a sociedade, ocorrem avanços nos processos de reestruturação produtiva. Decorrente da economia moderna, observa-se neste momento a universalização dos modos de consumo padronizados, que permite a difusão do setor de serviços e dos modos de vida.

A partir do século $X X I$, os processos de dispersão urbana e industrial continuam a ultrapassar os limites metropolitanos, porém, agora acompanhados também pela dispersão do setor de serviço, que passam a se organizar em rede e são advindos de mais uma etapa do processo de modernização industrial, ou seja, dos avanços dos processos de reestruturação produtiva.

A população de média e alta renda que agora reside distante dos grandes centros metropolitanos, principalmente nos municípios de pequeno porte, como Valinhos, Vinhedo, Louveira e Cajamar, estrategicamente localizados no eixo da rod. Anhanguera e com melhor oferta de qualidade e custo de vida, passa a requerer um suporte espacial adequado do setor terciário, atraindo também o comércio (cadeias globais que se organizam em rede) e o setor de serviços avançados para esses municípios.

A partir de 2000, intensifica-se a ocupação desse território por usos ligados à economia moderna, devido ao progresso tecnológico já incorporado à produção e à sociedade, bem como, às facilidades de transporte rodoviário e a contínua modernização da indústria.

Evolui-se da universalização dos mercados e dos modos de produção que geraram a extensão das regiões metropolitanas, à universalização dos modos de consumo padronizados que tem fortalecido centralidades de menor porte e garantido a possibilidade real de residir distante dos grandes centros metropolitanos.

Ressalta-se que os usos ligados à economia moderna ou à modernização da indústria estão presentes em todo o vetor noroeste, embora em municípios de menor porte com localização estratégica e formação recente, elas sejam mais evidentes do que em aglomerações urbanas ou metropolitanas já consolidadas, onde essas ocupações recentes se misturam com ocupações predominantes, ocorridas em outras etapas do processo de acumulação capitalista.

A constante atuação do mercado imobiliário, a modernização do setor terciário (shoppings, centros empresariais, supermercados, grandes cadeias comerciais, escolas, universidades), que passaramm a se organizar em rede, e a preencher e adensar os vazios ainda existentes, decorrentes dos processos de dispersão urbana, bem como, a 
mecanização da agricultura e pecuária, que já permite a produção sem grandes extensões territoriais, também passa a se manifestar no eixo em estudo.

Ou seja, novos usos ligados à economia moderna passam a integrar os vazios ainda existentes, decorrentes dos processos de dispersão urbana. Além dos condomínios fechados e das indústrias modernas fragmentadas mais relacionadas ao setor de serviços, também o comércio e o setor de serviços são atraídos para o eixo Anhanguera, como o Centro Empresarial Swiss Parq, em Campinas-2011, o Centro Tecnológico da Mazak, em Vinhedo-2013, e o Projeto do Shopping Iguatemi em Jundiaí, ainda em execução.
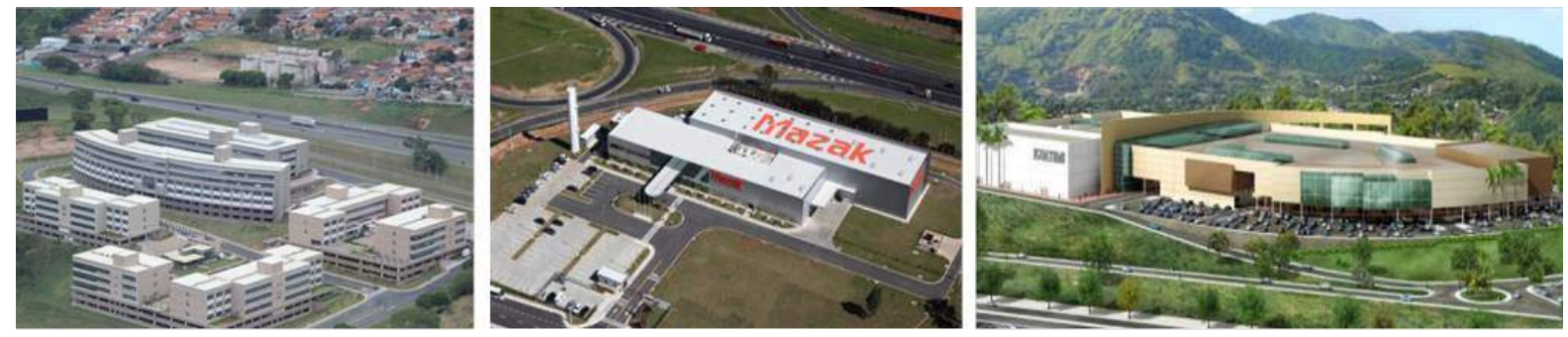

Figura 2.2: Centro Empresarial Campinas, Centro Tecnológico Mazak Vinhedo; Shopping Iguatemi Jundiaí. Fonte:http://swisspark.com.br; https://www.mazak.com.br; http://www.multiplan.com.br/pt-br/shopping-center

Além da extensão da escala metropolitana, que antes polarizava empregos, residências e comércio, esse processo gera o fortalecimento de novas centralidades, como as cidades de médio e pequeno porte, que se tornam cada vez mais independentes dos grandes centros metropolitanos, alterando novamente os fluxos de mobilidade e as características das relações sociais que se estabelecem nesse território.

O contínuo fortalecimento de centralidades de menor porte faz com que elas se tornem cada vez mais autônomas e insubordinadas à polarização de uma única centralidade, como São Paulo, Campinas e Jundiaí, acarretando transformações territoriais significativas nos municípios de pequeno porte atravessados pelo eixo Anhanguera.

Esse processo reduz os deslocamentos unidirecionais que caracterizam as centralidades metropolitanas tradicionais e aumenta os deslocamentos multidirecionais que passam a ocorrer em escala regional, aumentando os deslocamentos rodoviários.

A tendência observada é de transição das configurações territoriais das regiões metropolitanas de Campinas e São Paulo, polarizadas inicialmente por um único centro urbano bem definido (Campinas e São Paulo), para uma nova configuração regional, caracterizada por aglomerações policêntricas, que aumentam a importância dos municípios de pequeno e médio porte (Cajamar, Jundiaí, Louveira, Vinhedo e Valinhos).

Nas metrópoles com processo de urbanização ocorrido em outros períodos como Campinas e São Paulo, embora suas periferias também passem por esse processo de 
dispersão do setor de serviços e aglutinacão de áreas dispersas com configuração de novos pequenos centros de apoio, já existe um centro fortemente consolidado. Portanto, suas configurações territoriais, bem como suas dinâmicas espaciais ainda são notadamente baseadas em uma relação hierárquica mais rígida entre centro/periferia.

Dematteis (1998), observa três modelos de morfologia urbana advindos da continuidade dos processos de dispersão urbana. Peri-urbanização, expansão radial e periférica com dilatação progressiva das coroas externas e portanto redução dos núcleos centrais. Difusão Reticular, desconcentração com raio mais alargado constituindo redes de tecidos mistos residenciais e produtivos, industriais, terciários, agroindustriais e turísticos. E a superposição de ambas as formas, onde se integram áreas monocêntricas e policêntricas.

Essa sobreposição de formas é notada no vetor noroeste, onde dinâmicas de dispersão mais avançadas, distanciam-se dos núcleos urbanos e metropolitanos consolidados e se estendem ao longo dos eixos rodoviários, configurando novas centralidades. Esse processo de interação e complementariedade socioespacial, passa a constituir um novo Território Metropolitano constituído por áreas monocêntricas e policêntricas.

Do ponto de vista regional, esse processo gera 0 fortalecimento da escala macrometropolitana, cada vez mais estruturada por eixos rodoviários, apresentando uma morfologia urbana linear e poli-nucleada com várias centralidades, em detrimento das áreas metropolitanas tradicionais, que apresentam forma centrífuga e mono nucleada.

Esses municípios terão sua capacidade de desenvolvimento e atração intensificada quanto maior for sua relação com o eixo Anhanguera/Bandeirantes que estrutura e garante a mobilidade dessa região, embora a partir de 2006, já se observe problemas de congestionamento em ambas as rodovias.

A evolução técnica das infraestruturas que estruturam esse vetor, não acarreta, mas atrai e permite que novos usos ligados à economia moderna se manifestem e fortaleçam novas centralidades, que aos poucos se tornam cada vez mais autônomas e menos subordinadas às aglomerações ou metrópoles tradicionais.

Observa-se que esse corredor de riqueza, constituído pelo sistema de rodovias Anhanguera/ Bandeirantes, promove e atrai um desenvolvimento urbano e econômico linear que acompanha seus fluxos e redefine um novo arranjo, um novo Território Metropolitano. 
Além das tecnologias de comunicação esse novo território metropolitano tem como suporte espacial a contínua ampliação das faixas de rolagem das rodovias Anhanguera/Bandeirantes, bem como a conclusão das obras do Rodoanel.

A finalização, em 2002, do trecho oeste do rodoanel; em 2010, do trecho sul, ambos pela Dersa; em 2015, do trecho leste, pela SPMar; e finalmente a conclusão prevista para 2019 do trecho norte pela Dersa, viabilizam a conexão nacional desse novo Território Metropolitano.

Com 176 quilômetros de extensão circundando a região central da Grande São Paulo, O Rodoanel (SP-21), é uma rodovia estadual fechada. Porém embora com acesso restrito, a simples presença desta infraestrutura viária ocasionou um intenso movimento de especulação imobiliária e de ocupações irregulares em suas margens.

Observa-se nos municípios de pequeno porte, Valinhos, Vinhedo, Louveira e Cajamar, localizados no eixo Anhanguera, um processo recente de transição de uma forma de ocupação territorial rural, depois uma ocupação urbana, a seguir metropolitana e então regional. A tendência observada é o da superposição de temporalidades, estruturada pela evolução dos eixos rodoviários que permitem a extensão de limites territoriais estabelecidos.

Conforme Raffestini (1993), trata-se aqui identificar quais são efetivamente as relações essenciais e existenciais cotidianas, e recuperar uma malha territorial, que nos permitirá atuar de forma mais integradora produzindo territórios mais homogêneos.

Contudo, conforme observamos na imagem abaixo, a constituição deste novo território metropolitano, não se enquadra em limites administrativos estabelecidos, e portanto, requer políticas urbanas mais abrangentes para sua gestão.

Ou seja, trata-se de um importante corredor de mobilidade e riqueza, que do ponto de vista espacial, ao mesmo tempo, que estrutura um novo território homogêneo impactado pelas mesmas dinâmicas mais avançadas de urbanização, constitui-se por municípios que pertencem a diferentes regiões administrativas e metropolitanas, e que portanto, são administrados de forma particular.

Os municípios de Valinhos e Vinhedo ( pertencentes a R. M. de Campinas), Louveira ( pertence a aglomeração de Jundiaí) e Cajamar ( pertencentes a R. M. de São Paulo), não possuem políticas públicas compartilhadas que os fortaleçam e garantam um crescimento equilibrado desse novo território metropolitano. 
[...] trata-se de redescobrir, para as coletividades, malhas concretas que se oponham às malhas abstratas propostas pelo Estado. Estamos certamente no limiar de uma era na qual a região, a que é vivida, desempenhará, um papel cada vez maior para as diversas comunidades ( RAFFESTINI, 1993, p.185).

Além disso, observa-se que este mesmo corredor de riqueza que atrai dinâmicas urbanas análogas e ligadas à economia moderna, estruturando e definindo um novo Território Metropolitano, também o segrega na escala local.

O capitalismo que se globaliza e se emancipa do território nacional, inscreve-se num processo de reterritorialização e desterritorialização (GHORRA-GHOBIN, 2015) que, aliado à perspectiva de inovações tecnológicas produz uma fragmentação urbana.

A superposição de demandas globais, regionais e interesses pré-capitalistas no caso de São Paulo e do Brasil, são resultantes de diversas temporalidades que procuramos descrever. A essa nova configuração que corresponde a reterritorialização contemporânea, denominamos de novos Territórios Metropolitanos.

Conforme veremos no capítulo III, que se limitará à escala local ou intra-urbana, serão analisadas a partir de observações empíricas, as recentes transformações no tecido urbano de municípios de pequeno porte localizados neste eixo produtivo nacional, e o impacto que as formas avançadas de urbanização revelam em seu interior.

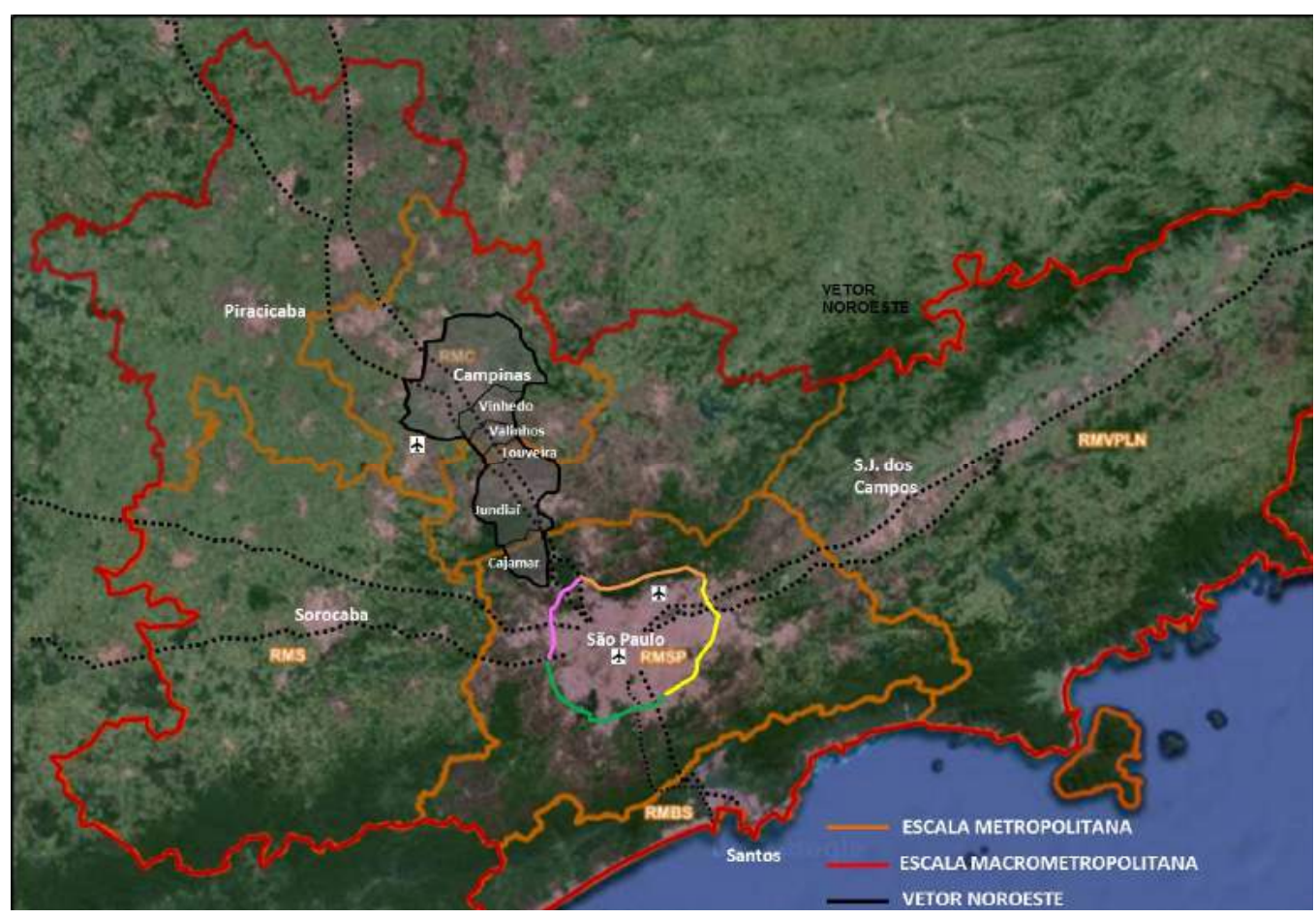

Figura 2.4: Vetor Noroeste inserção a Macrometrópole Paulista.

Fonte: Elaborado a partir de imagens http://www.emplasageo.sp.gov.br 
CAPÍTULO 3

\section{Escala Local: Integração e}

\section{Segregação em Territórios Metropolitanos.}

Observações empíricas demonstram que a intensificação das recentes dinâmicas de dispersão, com ênfase para o setor e serviços, tem configurado um tecido urbano contíguo e integrado entre os municípios de pequeno porte localizados no eixo Anhanguera. Revela-se qui um novo Território Metropolitano, que apesar da sua aparente semelhança estrutural, apresenta segregação territorial. 


\subsection{Continuidade Territorial e um Novo Arranjo Metropolitano.}

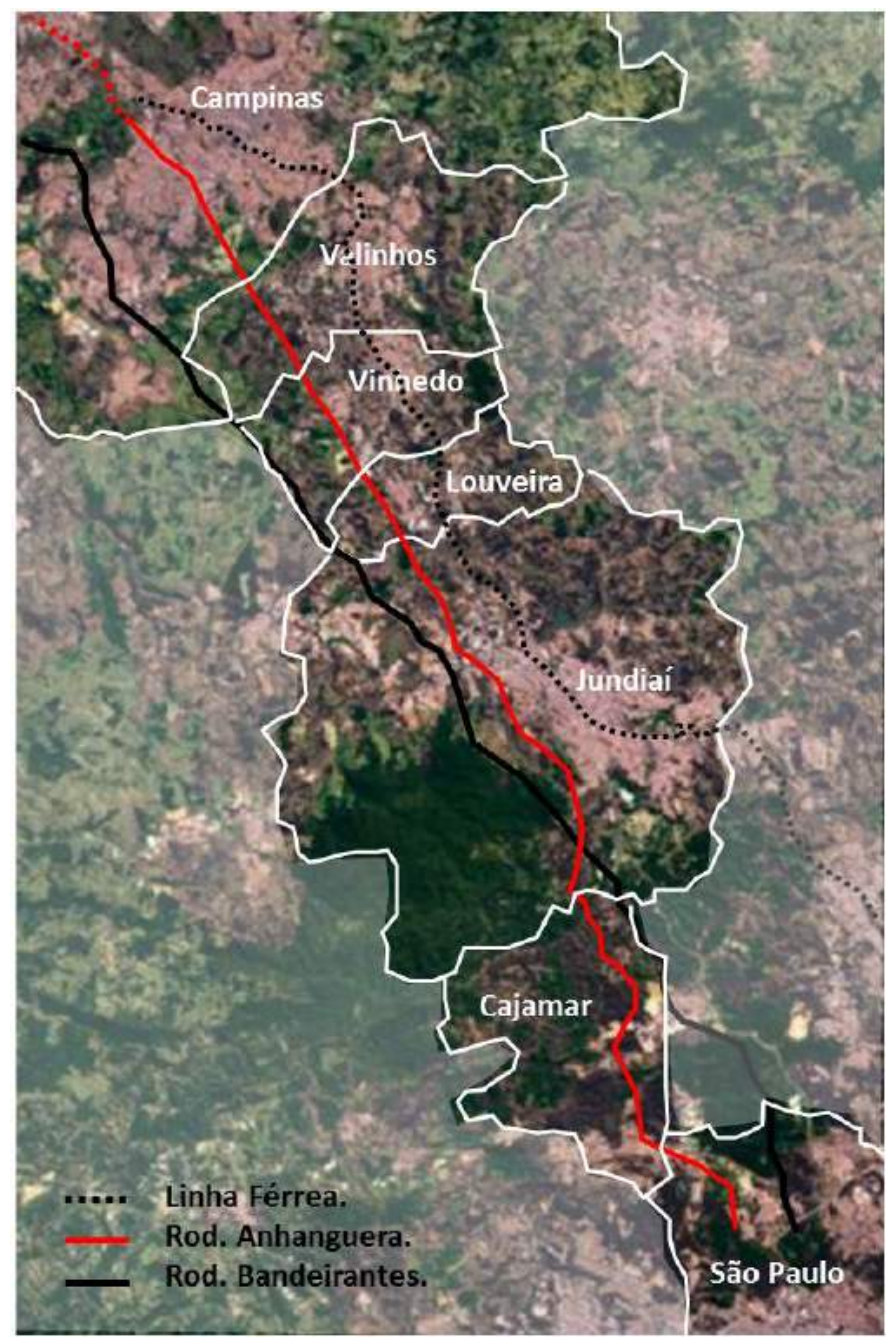

Figura 3.0: Mancha urbana e principais eixos que atravessam municípios do vetor noroeste paulista.

Fonte: Elaborado a partir de imagens http://www.emplasageo.sp.gov.br,

Como visto, processos de reestruturação produtiva e globalização avançada configuram novos territórios metropolitanos que, na sua dispersão, redefinem conceitos e incluem temporalidades históricas fragmentadas, locais e globais (EIGENHEER;SOMEKH, 2017).

Processos de reestruturação produtiva avançada, predominam em todo o vetor noroeste paulista, embora nos municípios de menor porte em processo de urbanização recente, sejam mais evidentes do que nas metrópoles contemporâneas, onde os novos usos acabam se misturando com ocupações relacionadas a outros contextos sócio-econômicos.

Conforme visto, os primeiros assentamentos dos municípios desse eixo se originam no século XVIII, com a penetração da rota das bandeiras que saíam da vila de São Paulo rumo às terras de Goiás, passando por Jundiaí e Campinas, e estabelecendo locais de pouso para viajantes ou tropeiros. Ou seja, essa rota de penetração foi responsável pela criação de uma rede de núcleos urbanos ao longo do vetor noroeste. 
No século XIX, o desenvolvimento da produção agrícola e da área rural, que tinha como principal produto de exportação, o café, foi de grande importância para o processo de industrialização e urbanização destes municípios, ao longo do século XX.

A partir de 1868, com a extensão da Companhia Paulista de Estrada de Ferro, de Jundiaí a Campinas, as antigas trilhas são praticamente abandonadas, destinando-se apenas a passagem de animais, ou boiadas, que não podiam ser transportados pelo trem, constituindo-se a Estrada da Boiada.

A seguir, em 1922, a precária Estrada Velha (SP -332), aberta sobre alguns trechos da antiga Estrada da Boiada, e assim atualmente denominada, passa a ser a primeira conexão viária entre a capital e o interior.

Ou seja, o vetor noroeste é um eixo histórico que teve seu desenvolvimento econômico e urbano apoiado em sua rede de infraestrutura, que direcionou o desenvolvimento urbano linear desses municípios, ou seja, sempre acompanhando seus eixos produtivos.

Dos caminhos de tropa, à ferrovia, a seguir à Estrada Velha aberta em 1922, à rodovia Anhanguera na década de 1950 e finalmente à rodovia dos Bandeirantes, inaugurada na década de 1970.

Atualmente, esses eixos históricos se transformaram nas principais conexões entre Jundiaí, Louveira, Vinhedo, Valinhos e Campinas e apresentam intenso fluxo de veículos com congestionamentos frequentes nos horários de intenso movimento.

Com relação à linha férrea ainda existente, por motivos econômicos, na década de1970, a Companhia Paulista de Estradas de Ferro, que já administrava outras rodovias paulistas, passa a ser denominada FEPASA - Ferrovia Paulista S.A, e em 1998, é incorporada integralmente à RFFSA Rede Ferroviária Federal S.A.

Em 1999, a malha paulista foi objeto de licitação, vencido pelo consórcio FERROBAN Ferrovias Bandeirantes S.A., que obteve sua concessão por um período de 20 anos. A FERROBAN teve seu controle indireto assumido pela América Latina Logística, que hoje administra todo o deslocamento de cargas na ferrovia paulista.

O eixo da linha férrea, atualmente utilizado apenas para transporte de cargas, é objeto de estudos do governo do estado, para uma futura licitação e compartilhamento de seus trilhos para transporte de passageiros, através do Trem Intercidades, no trecho entre Americana e São Paulo.

A possibilidade de retomada desse importante modal, certamente promoverá um desenvolvimento urbano ainda mais notável nos municípios do eixo Anhanguera. 
Atualmente a linha férrea está bem conservada, e é acompanhada por grandes avenidas que foram abertas acompanhando o seu percurso.
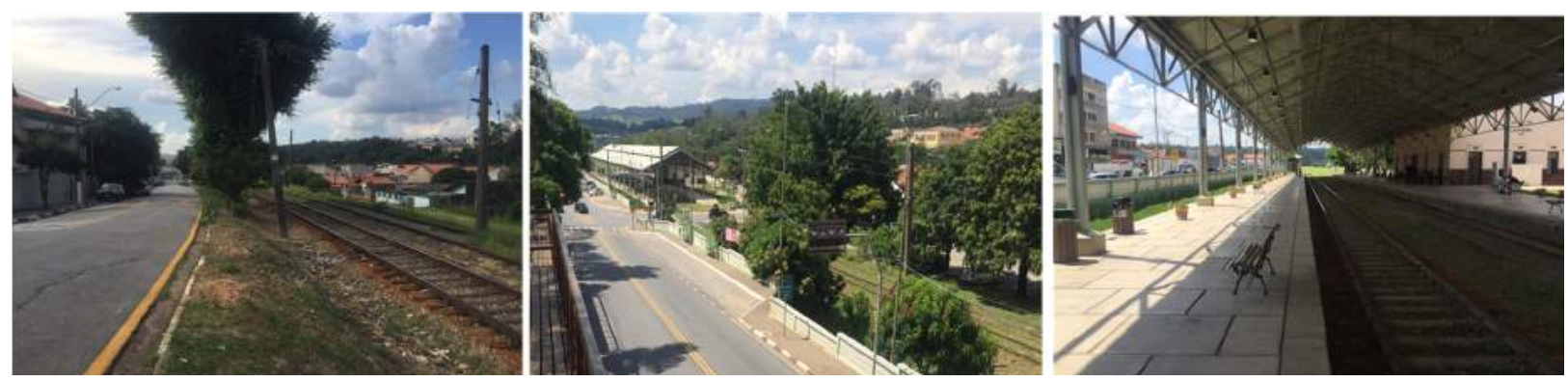

Figura 3.1: LINHA FÉRREA, em um trecho de Vinhedo, Louveira e Valinhos.

Fonte: Fotos de autoria própria. Daniela M. Eigenheer - 05 de fevereiro 2018.

Já Estrada da Boiada, SP-332, atravessa os municípios de Valinhos, Vinhedo, Louveira e Jundiaí, e grande parte do seu traçado de pista simples foi pulverizado por avenidas e ruas dos municípios que atravessa, recebendo distintos nomes oficiais. É utilizada quase que exclusivamente para acesso às cidades lindeiras e para aqueles que querem evitar os altos pedágios do sistema Anhanguera-Bandeirantes. Atualmente a estrada apresenta intenso fluxo de veículos, e é acompanhada por uma sequência de muros contínuos diferenciados que envolvem grandes condomínios residenciais horizontais.
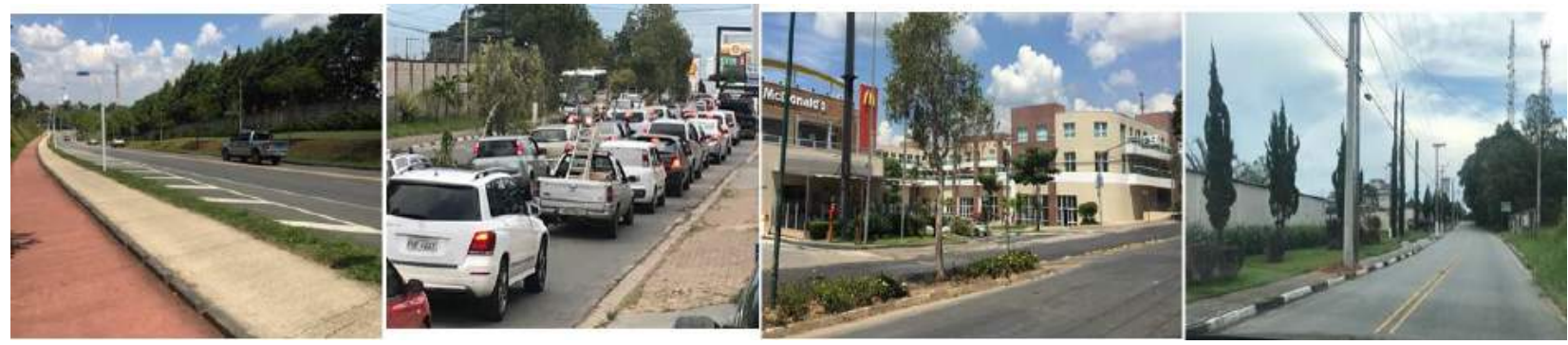

Figura 3.2: ESTRADA DA BOIADA Valinhos, Vinhedo, Louveira. Ciclovia, tráfego, comércio e condomínios. Fonte: Fotos de autoria própria. Daniela M. Eigenheer - 05 de fevereiro 2018.

Ao mesmo tempo, esses novos usos se misturam com áreas agrícolas que imprimem um caráter rural e campestre a esses municípios ocupados por condomínios fechados e atravessados pelo mais importante vetor econômico do país.
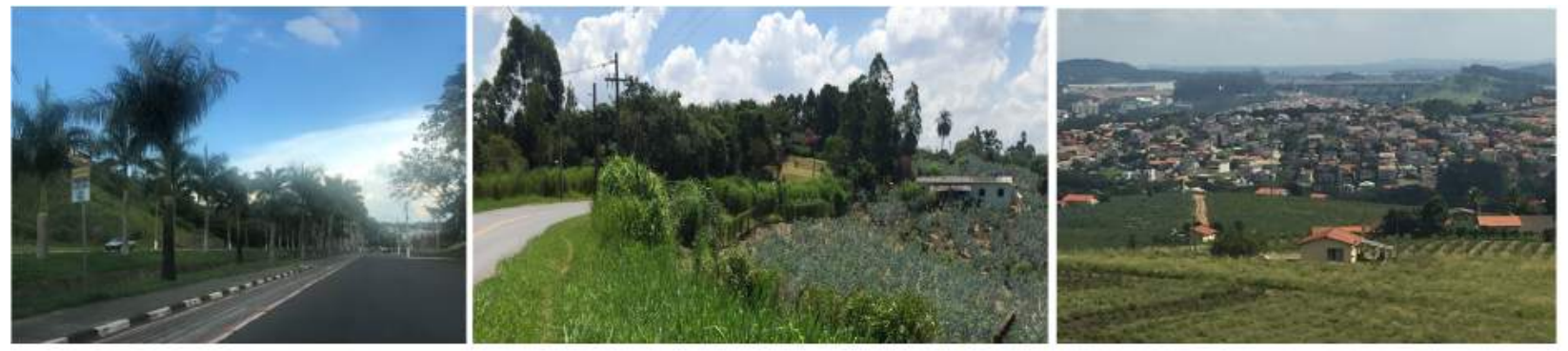

Figura 3.3: Avenida seguindo a linha férrea. Fruticultura estrada Boiada. Áreas rurais entre condomínios.

Fonte: Fotos de autoria própria. Daniela M. Eigenheer - 05 de fevereiro 2018. 
Em seu eixo entre Louveira e Vinhedo, a Estrada da Boiada é acompanhada por chácaras e condomínios. Entre Vinhedo e Valinhos, além dos condomínios predomina também o setor de serviços, cadeias de restaurantes, hipermercados, bancos, farmácias, e áreas de cultivo. No trecho entre Valinhos e Campinas, além da presença da ciclovia, indústrias modernas, condomínios de luxo, e o Colégio Porto Seguro margeiam as pistas da antiga estrada.

Com exceção de Cajamar, separado de Valinhos, Vinhedo e Louveira, pelo município de Jundiaí, e cujo passado remete à exploração de minério, a economia desses municípios era baseada na agricultura, que os tornou grandes produtores de frutas, sendo que muitos ainda investem em fruticultura e são integrantes no conhecido circuito das frutas, com o intuito de estimular o desenvolvimento regional para a permanência do homem no campo, por meio do turismo rural, embora atualmente o setor primário tenha papel pouco relevante em suas economias.

Até 1950 esses munícipios de pequeno porte, localizados no eixo Anhanguera, eram considerados como bairros e vilas de suas áreas urbanas adjacentes, Campinas, São Paulo e Jundiaí. Ou seja, só foram emancipados à categoria de município na segunda metade do século XX. Portanto, têm um processo de urbanização recente.

A urbanização desses municípios, ocorrida no contexto da desconcentração industrial, nas décadas de 1960, 1970 e 1980, foi caracterizada por uma forma de ocupação de baixa densidade através da implantação predominante de chácaras de lazer e importantes indústrias que aos poucos foram originando os bairros operários.

Ao longo do tempo essas indústrias foram sofrendo processos de aquisição e fusão, Saint Gobain-Vinhedo (antiga Carborundum Company), Unilever-Valinhos (antiga Gessy), Unilever-Vinhedo (antiga Elida Gibbs), Rigesa-Valinhos (antiga Gerin e Focesi), Eaton (antiga Clark Ltda), Asten-Valinhos. Algumas ainda permanecem com instalações centrais, agora cercadas pelo processo de urbanização da cidade, como a Unilever e a Rigesa.

A partir da década de 1990, uma nova indústria, mais moderna, e advinda da restruturação da produção, agora se instala de forma dispersa e fragmentada no eixo da rod. Anhanguera: Eaton (Valinhos - 1996), Procter \& Gamble P\&G (Louveira-1997), DHL Supply Chain (Louveira-2000), Natura (Cajamar-2001), Belenus (Vinhedo-2011), Karcher Brasil (Vinhedo-2013), Centro Tecnológico Mazak (Vinhedo-2013).

Além destas, a partir de 2000, também os condomínios industriais e os centros de logística, advindos da fragmentação da indústria e das novas tecnologias de comunicação, predominam no estratégico eixo Anhanguera, e fragmentam ainda mais 
esse vetor: Volkswagen Parts \& Accessories Center (Vinhedo-2004), Distribuidor Park (Louveira- 2006), Depósito Marabrás (Cajamar-2006), Agv Logística (Vinhedo-2006), Distribution e Industrial Park (Cajamar-2006 e 2014).

Observa-se a substituição de uma ocupação territorial mais densa e uniforme, ao longo da linha férrea, e seu deslocamento para áreas mais afastadas e extensas ao longo dos eixos viários. Antigas fazendas agrícolas se transformam em chácaras e em condomínios fechados, a fim de atender à demanda de imigrantes abastados na região, em busca de segurança e qualidade de vida. Além disso, observa-se o incremento de ocupações industriais.

Conforme Cunha e Miglioranza (2006), a emergência dos condomínios fechados ao longo da década de 1990, e do êxodo em grande escala de pessoas com melhores condições financeiras dos grandes centros (São Paulo, Campinas e outros) para cidades menores e áreas rurais, em busca de qualidade de vida, fez com que a direta relação entre pendularidade e pobreza, existente no país até a década de 1970, deixasse de existir.

Análises recentes sobre dinâmicas urbanas têm demonstrado uma tendência de migração de considerável parcela populacional dos grandes centros metropolitanos, para municípios de pequeno e médio porte, à procura de melhor qualidade e custo de vida, com acesso facilitado à moradia e aos serviços básicos.

Esses municípios de pequeno porte sempre foram diretamente influenciados e impactados pela extensão das dinâmicas dos centros urbanos e metropolitanos, limítrofes ou não a eles, que se refletem em seus territórios. A dinâmica metropolitana é estendida para esses territórios com aumento dos fluxos multidirecionais.

Observa-se que Vinhedo, além de ser impactado pela região metropolitana de Campinas também recebe grande contingente populacional da região metropolitana de São Paulo, embora esteja territorialmente separado desta. O mesmo ocorre com o município de Louveira, impactado tanto pelas dinâmicas de Jundiaí como de Campinas.

Exemplificando esse processo, observa-se o surgimento de inúmeros empreendimentos habitacionais de alto padrão, estruturados na forma de condomínios horizontais fechados, que em sua maioria se localizam afastados e não se relacionam diretamente com a centralidade urbana a que pertencem.

Dos quatro municípios em estudo, Valinhos é o que apresenta maior concentração de condomínios horizontais ou loteamentos fechados, em torno de 100 unidades ( SCIOTA, 2016). 
Como consequência deste processo, esses municípios de pequeno porte, Cajamar, Louveira, Valinhos e Vinhedo, têm apresentado, além do aumento considerável de seus Pibs per capita, taxas de crescimento da população maiores dos que as aglomerações urbanas e metropolitanas em que estão inseridos, São Paulo, Jundiaí e Campinas. Ou seja, possuem dinamismo demográfico e econômico, proporcionalmente maiores, do que grandes centros, o requer atenção do ponto de vista territorial e urbano.

Conforme Anexo II, atualmente os municípios do eixo Anhanguera têm maior concentração de seus PIBs no setor terciário, área da economia que integra as atividades do comércio e da prestação de serviços, a terceirização impulsionou esse crescimento. Muitas indústrias buscando vantagens econômicas optaram por terceirizar os serviços que não se relacionam diretamente com seu produto final, reduzindo departamentos específicos e funcionários responsáveis em exercer funções complementares como limpeza, embalagem, refeições e segurança.

A indústria que tem se instalado na região, é resultante desse processo de fragmentação e modernização industrial e se relaciona com o setor de serviços. Por exemplo, a indústria CCL Label, líder global no fornecimento de rótulos, etiquetas e embalagens, e a indústria Karcher fornecedora de sistemas, produtos e máquinas para limpeza industrial, ambas atendendo as mais importantes marcas e indústrias do mercado.

Além disso, registra-se um aumento de importância dos serviços e a presença de produtos industrializados mais aprimorados, cadeias de serviço globais, atividades ligadas ao setor terciário avançado, típicas de regiões metropolitanas; atividades vinculadas à economia global, como serviços financeiros, de informação, educacionais e culturais, empresas orientadas para o mercado internacional, telecomunicações, serviços de consultoria em gestão empresarial, reproduzem-se dos grandes centros metropolitanos para esses municípios de pequeno porte a fim de atender demandas de uma nova população que aí se estabelece.

Shopping Center Valinhos, Office Mall Vinhedo, Outlet Premiun, Red Ballon, Colégio e Curso Etapa, Hipermercado Carrefour, CRr Hansen (empresa Dinamarquesa no ramo da biociência), além das cadeias globais de lojas, restaurantes e serviços que se multiplicam pelo território, são alguns exemplos.

Nota-se também a presença de infraestruturas ou redes de comunicação mais aprimoradas para conexões diárias entre empresas e instituições, notáveis rodovias, a proximidade de aeroportos internacionais, recursos humanos de alta qualificação para atuar em grandes empresas e realizar atividades inovadoras. 
O recente processo de industrialização e urbanização desses munícipios permite que atualmente se evidencie, nesses territórios, o impacto que a intensidade dos novos padrões de ocupação, relacionados com a economia moderna tem promovido, uma vez que não predominam ocupações de outros períodos.

Observa-se abaixo, nos distritos industriais dos municípios de Vinhedo, Louveira e Cajamar, a predominância de ocupações mais relacionadas com o setor terciário moderno e com a produção nacional, como tecnopolos e condomínios industriais, logísticos e residenciais, ocupando grandes extensões de áreas, além das cadeias de serviços globais que agora se manifestam, conformando um território pouco denso e cada vez menos poroso. mas ainda fragmentado.
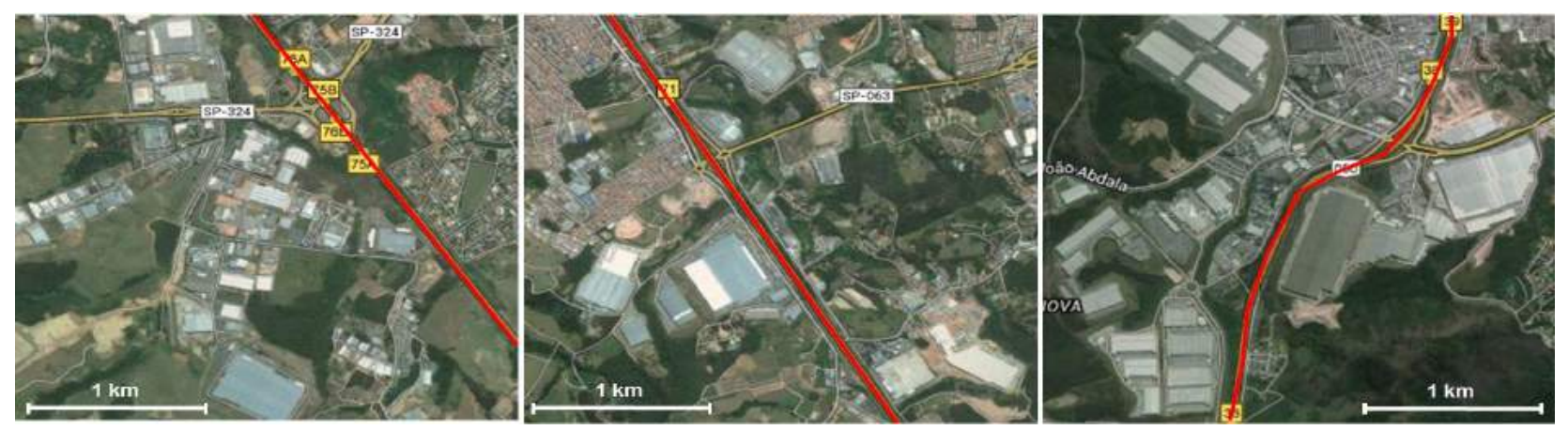

Figura 3.4: Áreas industriais adjacentes a Anhanguera: Vinhedo km 75; Louveira km 71; Cajamar- Km 36. Fonte: Elaborado a partir de imagem: www.emplasageo.com.br - acessado em 06042017.

Quanto à morfologia desses tecidos, observa-se abaixo, que a maioria dos vazios urbanos, já foi ocupada pela intensificação da dinâmica de dispersão urbana. Uma parcela pequena esta em processo de loteamento e ocupação, e outra reservada para áreas rurais e de preservação ambiental.
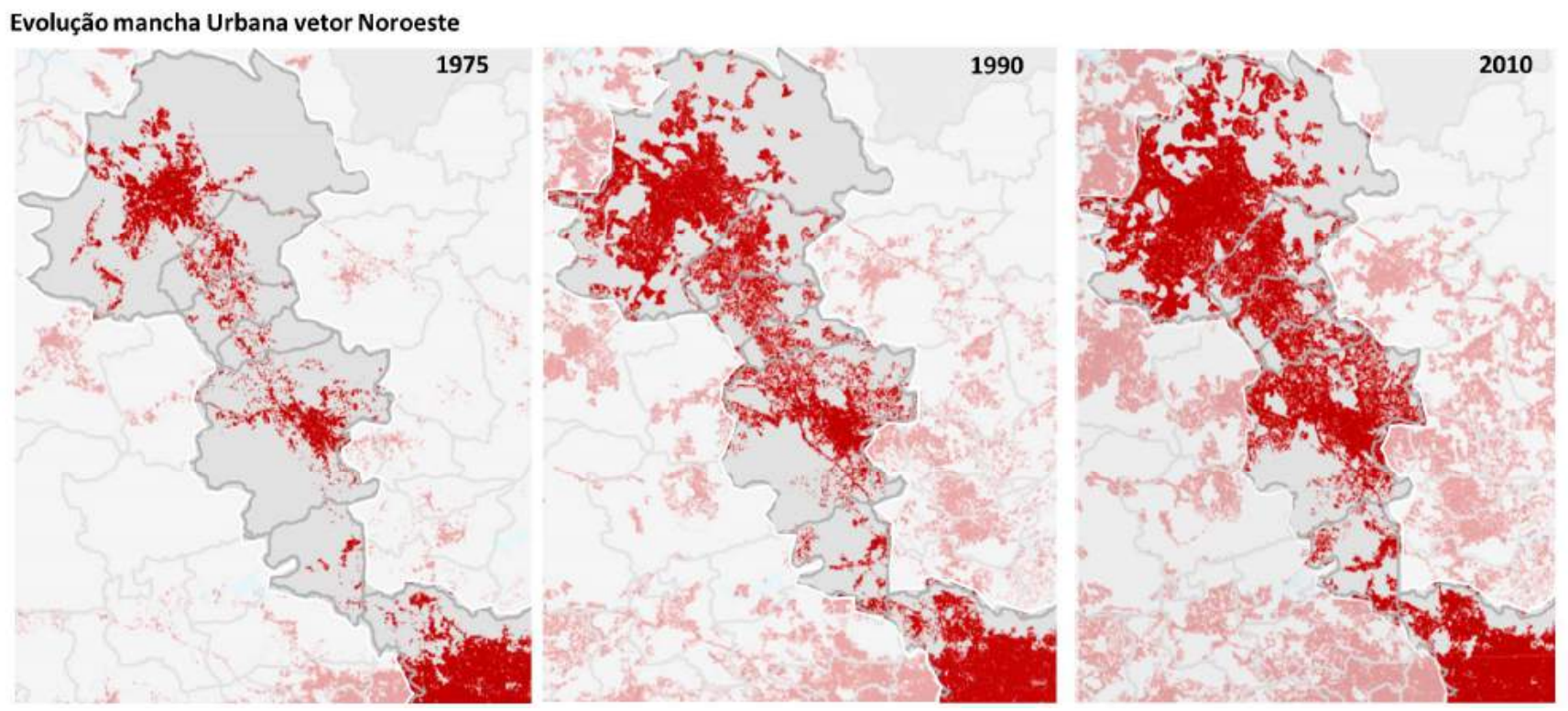

Figura 3.5: Evolução Mancha Urbana Vetor Noroeste 1975-2010.

Fonte: Elaborado a partir de imagem cedida pelo LUME- Laboratório de urbanismo da metrópole. 
$\mathrm{Na}$ imagem acima, a evolução da mancha urbana do vetor noroeste, até a década de 1990, demonstra um território que se caracteriza por porosidades que se intercalam com ocupações dispersas, com exceção das metrópoles de Campinas e São Paulo, consolidadas em outros períodos, com território já caracterizado por uma continuidade territorial predominante, exceto em suas periferias.

O adensamento deste território por usos ligados aos avanços da economia capitalista, como os condomínios fechados, a indústria moderna e o setor de serviços e suas cadeias globais, têm promovido a aglutinação de áreas dispersas e, portanto, observa-se uma alteração na sua morfologia territorial, que não se caracteriza mais por vazios intraurbanos resultantes das dinâmicas de dispersão e fragmentação territorial.

Ou seja, a partir do século XXI, os municípios de pequeno porte localizados no vetor noroeste da capital paulista (Valinhos, Vinhedo, Louveira e Cajamar), não têm mais seu território caracterizado por dinâmicas de dispersão urbana, mas por recentes dinâmicas de adensamento dos espaços intersticiais, resultantes das dinâmicas anteriores de dispersão, conforme se observa nas imagens de satélite que serão a seguir expostas.

Ao invés de um tecido urbano esgarçado, predominam tecidos que apresentam continuidade territorial, porém que não se originaram a partir de um núcleo central, mas sim a partir da aglutinação de áreas dispersas, que são atraídas por eixos históricos e lineares de desenvolvimento.

Enquanto a dispersão industrial, urbana, e do setor de serviços de grande porte, como shoppings e hipermercados, e universidades, requerem grandes áreas urbanas, geralmente mais afastadas, pouco adensadas e servidas de infraestrutura, a dispersão dos serviços de menor porte parece não seguir essa mesma lógica de ocupação territorial.

Cadeias de restaurantes, lojas, farmácias, bancos, escolas, buscam preencher porosidades territoriais, ou seja, abastecem áreas já urbanizadas, e portanto dificilmente acarretam extensão de escalas, mas sim formação de pequenos centros de consumo, que geram adensamento, coesão e integração urbana.

Quando tecidos urbanos de diferentes municípios se conurbam, como no caso dos municípios do eixo Anhanguera, estabelece-se relações socioeconômicas que os fortalecem e que vão além de limites territoriais historicamente estabelecidos, conformando um novo território que atrai usos e atividades exclusivos de grandes centros metropolitanos. 
Salienta-se que o adensamento territorial, por novos usos ligados à economia moderna, continua a reproduzir as mesmas dinâmicas históricas de segregação socioespacial e de degradação ambiental, que requerem políticas públicas, para sanar os conflitos decorrentes deste processo.

O que se nota é um tecido urbano mais caracterizado pela continuidade do que pela descontinuidade territorial, embora bastante segregado socialmente apesar de uma aparente homogeneidade.

Como visto no capítulo anterior, embora não se insira nos limites administrativos estabelecidos, do ponto de vista espacial, constitui-se um território homogêneo, onde dinâmicas urbanas avançadas predominam e constituem uma totalidade.

Contudo, um território segregado do ponto de vista de suas relações locais, onde a predominância de dinâmicas e usos ligados à economia moderna, oculta uma tecido urbano bastante diferenciado.

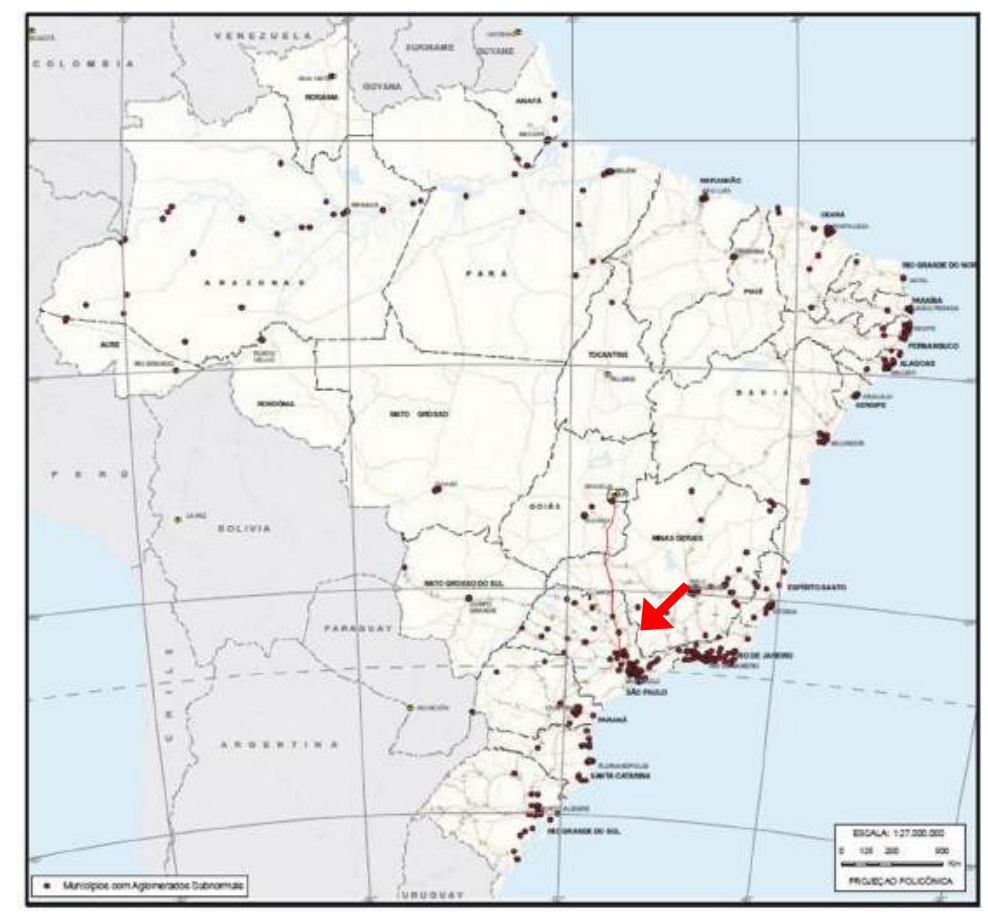

Figura 3.6: Distribuição dos aglomerados subnormais no país com concentração no vetor noroeste.

Fonte: IBGE (2013).

O mapa acima demonstra que apesar do vetor noroeste ser um corredor de riqueza nacional, ele também é um eixo que concentra ocupações precárias. Denominadas pelo IBGE (2013), de aglomerados subnormais, essas ocupações enquadram-se conforme os critérios de padrões de urbanização e/ou de precariedade de serviços públicos essenciais, nas seguintes categorias: invasão, loteamento irregular ou clandestino, áreas invadidas e loteamentos irregulares e clandestinos regularizados em período recente. 
Além da precariedade, localizam-se isolados no território e são resultados de um processo histórico e excludente de desenvolvimento urbano do país que reforça relações de poder e domínio de classes sobre o território, e que produzem ilegalidades no uso e ocupação do solo de grandes centros metropolitanos, como também, de aglomerações urbanas de menor porte.

Assim como a maioria das cidades Brasileiras, o processo de urbanização desses municípios do eixo Anhanguera, também ocorre de forma desigual gerando a segregação de bairros de baixa renda, como o bairro da Capela em Vinhedo, localizado na margem esquerda da rodovia, sentido norte, porém sem acessibilidade a ela, o mesmo ocorre no bairro Santo Antonio, em Louveira. Trata-se de antigos bairros operários que foram se consolidando junto às primeiras indústrias que se instalaram nesse vetor.

Além das ocupações precárias e dos bairros segregados, observa-se nesse território a predominância dos condomínios horizontais ou loteamentos fechados, que criam condições de vida particulares e ideais, com controle, segurança, limpeza, paisagem, independente do que exista do lado externo.

Os condomínios residenciais horizontais, predominantes nestes municípios, tiveram suas áreas estendidas devido à incorporação de áreas públicas no interior destas propriedades, lógica considerada legal até há pouco tempo. Além disso, essa forma de ocupação territorial altera a paisagem e contribui para a segregação e informalidade espacial, na medida em que aumenta o preço do uso do solo.

São produzidos por agentes imobiliários, em terras pouco valorizadas com acessibilidade, e de forma padronizada, com tipologias modernas que atendem a diferentes classes sociais que desejam habitar lugares socialmente similares.

Independente do porte, podem se localizar distantes das áreas centrais, pois sua valorização não se dá pelo lugar que ocupam no tecido urbano, mas pelo que o produto final agrega e tem a oferecer, ou seja, incorporam valor próprio, e quanto mais distantes da mancha urbana, mas rentáveis se tornam, pois mais barato é o preço de terra.

Ao mesmo tempo, classes sociais similares que se localizam na mesma margem da rod. Anhanguera, fecham-se entre muros em seus espaços coletivos, e também não se relacionam, embora residam nos mesmos condomínios horizontais de alto padrão.

Visto do alto um território homogêneo, estruturado por um corredor de riqueza, visto de baixo, relações determinadas por inclusões ou exclusões, e por relações sociais individualizadas onde consumo e trabalho cada vez mais se estruturam através de 
conexões virtuais, e onde espaços de lazer privado substituem espaços públicos de convivência coletiva.

Portanto, alguns desafios devem ser enfrentados pela administração pública. A ocupação urbana de mananciais e áreas rurais; infraestruturas de saneamento e transportes implantadas para atender os condomínios fechados, industriais e residenciais de alto padrão, porém que não se estendem às áreas adjacentes; áreas públicas e institucionais que se mantem no interior dos novos condomínios e se tornam inacessíveis a população em geral; tráfego urbano devido à interrupção e ausência de integração de vias urbanas, que são bloqueadas devido à implantação de grandes áreas privadas, cercadas por muros e de baixa densidade, são algumas reflexões necessárias.

Tendo em vista pressões imobiliárias sobre a municipalidade para implantação deste modelo de ocupação territorial que muito provável continuará a ser replicado, deve-se atentar para critérios de qualidade, para amenizar seus efeitos negativos sobre o território. Infraestrutura rodoviária, condomínios dispersos entre áreas agrícolas, indústria moderna, cadeias de serviços, avenidas arborizadas, e a possibilidade de retomada da linha férrea, fazem destes municípios estrategicamente localizados no corredor mais rico do país, atípicos objetos para intervenção e reflexão urbana.

A seguir, após um breve relato sobre o processo de urbanização de cada um dos municípios analisados, Valinhos, Vinhedo, Louveira e Cajamar, observou-se através de análises empíricas, as transformações urbanas que vem ocorrendo ao longo do século $\mathrm{XXI}$, em seus tecidos urbanos.

Imagens aéreas comparativas demonstrarão que a intensificação de novos usos do solo ligados à economia moderna tem acarretado transformações no tecido urbano desses municípios. Ou seja, observa-se o preenchimento de vazios urbanos e uma forte integração desses territórios que definem um novo arranjo urbano, ou um nono território metropolitano que merece observação.
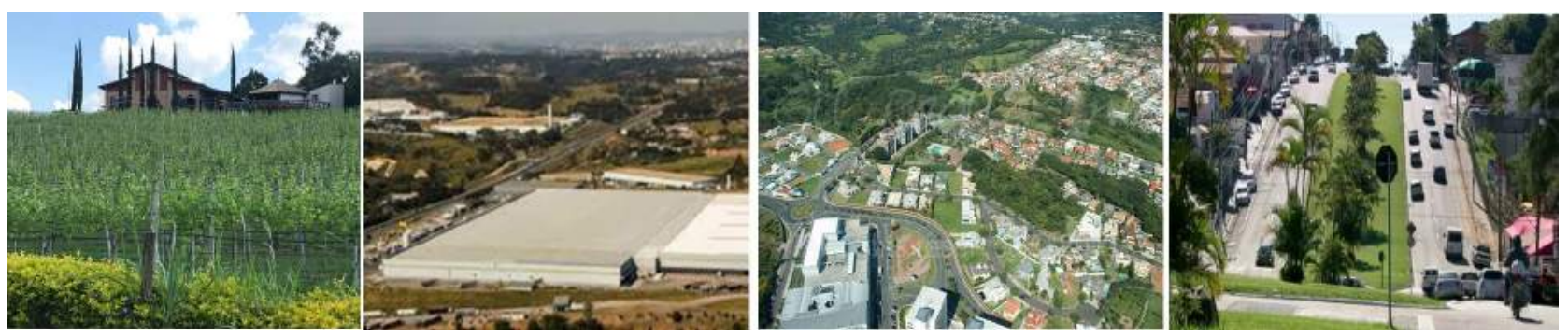

Figura 3.7: 1 Vinícola Louveira; 2 Indústria Anhanguera; 3 Condomínio Valinhos; 4 Serviços Vinhedo.

Fonte: (1 e 4) Fotos de autoria própria. 05 fev.2018; (3) http://mapio.net; (2) http://www.jcqimoveis.com.br 


\subsection{Município de VALINHOS.}

\section{População e Território:}

População estimada em 2018: 122 mil habitantes

Crescimento Anual População 2010/2018: 1,68 \% a.a

Área : 148,54 km2

Densidade demográfica 2018: 820,04 hab./km2.

Fonte: Dados fundação SEADE- http://www.imp.seade.gov.br. Acessado em 20/02/2018.

Pertencente à Região administrativa de Campinas, Valinhos tem como principais eixos as rodovias Anhanguera, Bandeirantes, Dom Pedro I, além do anel viário José Magalhães Teixeira, que conecta as rodovias Anhanguera e Dom Pedro I, pelas quais o município é diretamente servido.

Valinhos surgiu a partir de uma sesmaria outorgada em 1732, sendo o Pouso de Pinheiros o primeiro marco oficial de uma área dentro do atual município de Valinhos, provavelmente, o atual bairro Capuava (IBGE Cidades - Valinhos História e Fotos).

Campinas pertencia a Jundiái. Emancipou-se em 1797, elevando-se à condição de Vila de São Carlos (1797) e, posteriormente, a Cidade de Campinas (1842). A seguir, não se sabe precisar o período, foi fundada a vila de Valinhos, pertencente ao município de Campinas e caracterizada desde o início como uma área com grandes fazendas, dentre elas a Fazenda Dois Córregos e a Fazenda Capuava, de onde se originou bairros ainda existentes.

Tendo em vista as inúmeras fazendas cafeeiras, em 1872, inicia-se o tráfego ferroviário pela Companhia. Paulista de Estrada de Ferro, de Jundiaí a Valinhos, que substitui a precariedade das estradas por onde as cargas eram transportadas por mulas e burros.

A ferrovia foi imprescindível ao desenvolvimento da região. Inicialmente para o transporte do café rumo ao Porto de Santos. Com a abolição da escravidão em 1888 e a falta de mão-de-obra, estimula-se a imigração no país.

Os primeiros imigrantes italianos se instalam na região e fornecem um novo impulso à agricultura, tendo como principal produto agrícola com visibilidade nacional, o Figo Roxo.

Com a epidemia da febre amarela em 1889, muitos campineiros buscaram refúgio em Valinhos, o que possibilitou seu desenvolvimento e a futura constituição do distrito de Valinhos (IBGE Cidades - Valinhos História e Fotos). 
Em 1896, a pequena e próspera vila de Valinhos, pertencente a Campinas, foi elevada à categoria de Distrito da Paz. Em 1953, o Governo do Estado criou o município de Valinhos, oficialmente instalado em 1955. Apenas em 2005, Valinhos se torna autônoma no que diz respeito aos serviços judiciários, até então, realizados em Campinas.

A Grande Depressão de 1929, provocou a falência de grandes produtores de café no Brasil e a diversificação da produção agrícola, estimulando a instalação do processo de industrialização na região.

O crescente processo de urbanização do município, decorrente do início da industrialização que chegava no interior do estado, transformou a maioria das fazendas da região. A partir de 1970, áreas produtivas tradicionais começam a ser substituídas por novas construções, destinadas à residência, indústria, comércio e serviços.

A extensa e antiga Fazenda Capuava cedeu espaço para vários bairros residenciais, pequenas indústrias, comércio, escolas. Sua sede modernista foi projetada e construída entre 1929 e 1938 pelo arquiteto Flávio de Carvalho, cuja família adquiriu a fazenda no início do século XX. Na década de 1970 suas terras começam a ser desmembradas, vendidas e doadas.

Atualmente, a antiga e extensa área da fazenda, é ocupada por habitações populares, terrenos baldios e condomínios residenciais fechados, restando apenas uma pequena área rural, dentro do perímetro urbano de Valinhos.

A instalação industrial, iniciou-se em 1895, com um imigrante italiano fundador de uma pequena fábrica de sabão, que no futuro se transformaria na Companhia Gessy, e que, por sua vez impulsionaria o processo de industrialização, alterando o quadro urbano e rural de Valinhos.

Em 1961, a empresa anglo-holandesa Unilever adquiriu a Gessy, constituindo a Gessy Lever S/A , que possui atualmente uma extensa área edificada na região central de Valinhos.

Outras indústria alavancaram a industrialização em Valinhos, como a ainda existente e ampliada fábrica de papel, Cartonifício Valinhos S/A, situada ao lado da estação férrea, e a Gerin e Focesi, fábrica de papelão instalada na área central de Valinhos em 1943, e adquirida pela multinacional Rigesa S/A, em 1955.

Na década de 1960, a multinacional Equipamentos Clark instalou-se longe da área central da cidade, na margem direita da rodovia Anhanguera, sentido capital, promovendo o início da ocupação da zona rural e aconstituição do atual distrito industrial. 
Atualmente o município investe no agroturismo, visando explorar o potencial turístico das chácaras restantes, produtoras de uma grande diversidade de frutas, com ênfase para a produção de figo em larga escala. Além disso, possui produção industrial diversificada, com mais de 500 indústrias, com ênfase para setores dinâmicos e de alta tecnologia, e sedia cerca de 1.500 estabelecimentos comerciais.

Devido à sua conurbação com o município de Campinas, Valinhos tornou-se atrativa ao mercado imobiliário para instalação de condomínios residenciais de alto e médio padrão, em terrenos anteriormente ocupados por fazendas e chácara destinadas à produção de frutas. Foram atraídos também pela construção do Clube de Campos e pelo Country Clube de Valinhos, implantados na região nas décadas de 1950 e 1960, respectivamente.

Conforme abordagem de Miglioranza e Cunha (2006), Valinhos transformou-se em uma cidade-dormitório regional, para a camada da população de média e alta renda.

Outro fator de atração da população mais abastada em busca de qualidade de vida é o tradicional colégio bilíngue Porto Seguro. Em 1983, anterior aos inúmeros condomínios que hoje o ladeiam, o Campus Valinhos tornou-se referência de alto padrão de ensino, atendendo à população de maior poder aquisitivo.

Observa-se recentemente o incremento do setor de comércio e serviços para atender novos moradores da cidade, como o primeiro shopping-center do município. Inaugurado em 2007, o Shopping Valinhos não foi previsto para atender à alta renda, e portanto, perde em atratividade para os shoppings de Campinas, devido a sua proximidade. Além dele, torres de escritório, e principalmente, os condomínios fechados se multiplicam.

A evolução das dinâmicas de dispersão urbana e industrial e mais recentemente do setor de serviços, aliada à redução de áreas verdes e rurais, ao surgimento de assentamentos precários e irregulares e ao aumento de seus fluxos multidirecionais, demonstram a extensão das dinâmicas metropolitanas para esse município. 


\subsection{Município de VINHEDO.}

\section{População e Território:}

População estimada em 2018: 75 mil habitantes.

Crescimento Anual População 2010/2018: 2,09 \% a.a.

Área: 81,60 km2.

Densidade demográfica 2018: 917,38 hab./km2.

Fonte: Dados fundação SEADE- http://www.imp.seade.gov.br. Acessado em 20/02/2018.

Antigo distrito da Rocinha, pertencente ao município de Jundiaí, emancipou-se em 1949, quando foi denominado Vinhedo. Atualmente pertence à região metropolitana de Campinas. Possui 71.035 mil habitantes com significativa taxa de crescimento e ocupa a $7^{\circ}$ posição em PIB per capita do estado (Seade 2015). Suas primeiras ocupações datam do início do século XVIII, época do ciclo do ouro, quando servia de passagem para os bandeirantes que se deslocavam entre o interior, São Paulo e o porto.

$\mathrm{Na}$ década de 1920, a agricultura deixou de ser o principal ramo de economia. Três indústrias foram historicamente importantes e impactaram o desenvolvimento da região.

Em 1925 foi construída a primeira indústria do distrito, a Fiação e Tecelagem Sant'Anna, que posteriormente mudou o nome para B. Storani S/A.

Em 1947, foi fundada a Cerâmica Jatobá, que contemplava duas fábricas em Vinhedo que ocupavam 25 mil m² de área e empregavam mais de 400 funcionários. Em 1953 é fundada a The Carborundum Company, da British Petroleum, que em 1966 é adquirida pelo grupo francês Saint-Gobain, até hoje na cidade, e responsável por $80 \%$ da economia do município. (Prefeitura Municipal de Vinhedo-História da Cidade)

Apesar de estar passando por intenso processo de industrialização, iniciado na década de 1970, sua economia foi baseada inicialmente na atividade agrícola. Até 1980 , seu fluxo migratório era de população de baixa renda.

A seguir, passou a receber população de classe média e alta, em busca de qualidade de vida, dando origem as chácaras de veraneio, e aos condomínios fechados que hoje predominam no município.

Como os demais municípios, sua posição estratégica fez com que sua forma urbana fosse evoluindo a partir do desenvolvimento de eixos históricos e lineares para deslocamento de produção. 
A Estrada Velha, atualmente chamada de Estrada da Boiada SP-332, é responsável por grande fluxo de deslocamento entre Campinas, Valinhos, Vinhedo e Louveira. Com predominância de condomínios, serviços e indústria em seu eixo, já apresenta em alguns trechos problemas de congestionamento nos períodos de pico.

Inicialmente, essa estrada apresentava um tecido urbano formado por loteamentos e condomínios residenciais horizontais. Aos poucos, estes foram atraindo também o setor de serviços, transformando a antiga, precária e de terra Estrada da Boiada, em um importante eixo de mobilidade urbana e conexão com Valinhos e Campinas, com predominância de comércio e serviços modernos.

A inauguração da Via Anhanguera, em 1948, e depois, da rodovia dos Bandeirantes, em 1978, atraiu o desenvolvimento urbano e industrial também às margens dessas rodovias.

Conforme Cano (2002), os principais aspectos do processo de ocupação urbana do município são uma grande quantidade de condomínios residenciais fechados e chácaras de recreio ocupando mais da metade da área do município, com camadas de média e alta renda, que se localizam entre a rodovia Anhanguera e a Estrada da Boiada.

Como dito, a maioria da população de baixa renda se localiza a leste da Via Anhanguera, entre o distrito industrial de Vinhedo e o município de Valinhos. Essa região é conhecida como bairro da Capela.

Contudo, conforme será a seguir analisado, a existência de grandes vazios urbanos já não caracteriza mais esse território. $O$ intenso processo de ocupação e dispersão urbana cada vez mais vem produzindo um tecido urbano com predominância de continuidade territorial, ao invés de fragmentação.

Atentos aos problemas decorrentes do intenso processo de ocupação urbana que vem sofrendo, setores da administração municipal estão revisando o plano diretor do município com orientação da Emplasa, Empresa de Planejamento Metropolitano do Estado de S.P.

A análise das ortofotos demonstra a evolução nos processos de urbanização que vem ocorrendo desde 2006 no município, bem como sua relação com a economia moderna. 


\subsection{Município de LOUVEIRA.}

\section{População e Território:}

População estimada em 2018: 46 mil habitantes.

Crescimento Anual População 2010/2018: 2,83 \% a.a.

Área: 55,13 km2.

Densidade demográfica 2018: 802,99 hab./km2.

Fonte: Dados fundação SEADE- http://www.imp.seade.gov.br. Acessado em 20/02/2018.

Atualmente pertence à aglomeração urbana de Jundiaí. Assim como Vinhedo, Louveira pertenceu a Jundiaí por quase três séculos. Os dois municípios desmembraram-se de Jundiaí em 1948, quando Louveira se tornou um bairro de Vinhedo (ex-Rocinha), elevando-se à categoria de distrito em 1955 e de município em 1965.

Assim como os demais municípios, sua formação remete ao seu passado agrícola. $O$ município tornou-se um grande produtor de frutas, principalmente uva e atualmente integra o conhecido circuito das frutas. A comercialização de frutas impulsionou o turismo e o agronegócio da região com a promoção de festas e eventos que reúnem mais de um milhão de pessoas, como a tradicional Festa da Uva de Louveira, já em sua $41^{\circ}$ edição.

Grande parte deste território ainda é ocupado por usos rurais que vêm sofrendo forte pressão do mercado imobiliário, que almeja a expansão urbana do município para implantação de condomínios residências, instalações industriais e serviços, que tendem a expulsar as áreas agrícolas tradicionais.

A presença de condomínios residenciais de alto padrão, que já se estendem sobre áreas rurais como o Villagio Capriccio, e o Residencial Primavera, são destinados à população de São Paulo, Campinas e Jundiaí, à procura de qualidade de vida, o que acarretou transformações urbanas no tecido urbano do município. Loteamentos populares como Arataba e Monterrey também se expandem e ocupam áreas de mananciais.

O município de Louveira é dividido pela rodovia Anhanguera, que cada vez mais exerce atração de usos urbanos para suas margens. Além de uma rodovia de conexão regional, a Anhanguera assume também função de via de uso local, dividindo a cidade em duas partes: Centro e Bairro Santo Antonio.

Este último, com predominância de população de baixa renda, localiza-se a leste da Via Anhanguera, é conhecido como Quebra, e vem sofrendo visível desenvolvimento urbano. 
Além da Via Anhanguera, Louveira é atendida por mais três rodovias estaduais: Bandeirantes, Romildo Prado (que leva a Itatiba) e a antiga Estrada Velha de Campinas (oficialmente denominada SP-332).

Na última década recebeu indústrias do setor de logística como a Distribution Park Louveira, e a empresa global de carga e frete $\mathrm{DHL}$, que ocupam extensos terrenos nas margens da via Anhanguera. A DHL revolucionou o mundo da logística, e é a principal empresa de logística do mundo.

Esses centros de distribuição e logística acarretam um volume de caminhões e veículos que congestionam o principal acesso ao centro de Louveira, provocando trânsito intenso e congestionamentos na Via Anhanguera, sentido norte, em determinados horários.

O desenvolvimento industrial do município de Louveira foi impulsionado pela sua fácil acessibilidade, bem como, pela sua proximidade de grandes centros, principalmente, do município de Jundiaí, que possui pefil industrial e até hoje se abastece de operários dos municípios do seu entorno, como Louveira.

A partir de 1997, com a instalação da indústria Procter and Gamble do Brasil \& Cia, a atividade industrial de Louveira teve um impulso notável, atraindo outras indústrias para a região: Ahlstrom Papers Group; Ancor Pet Packaging;Valki Plásticos e Máquinas Ltda; Framplast Ind. e Com. de Plásticos; Dinoplast Ind. e Com. de Plásticos; Isolasil Tintas e Vernizes; Texifiber; Fibertex Louveira ProdutosTêxteis Ltda. Os frigorífcos também se destacam na região, fomentando o setor primário.

As indústrias se dispersam de forma iregular por todo território com ênfase para as zona industrial às margens da via Anhanguera. Com o incremento da atividade indústrial no município ocorreu o deslocamento da sua mão de obra rural para a indústria e comércio.

Conforme Harder (2007), entre 1970 e 2005, Louveira apresentou aumento de 86,44\% da sua população urbana e redução de $19,91 \%$ da população rural, além disso, apresentou extensão de 47,33\% de sua área urbana que, de 2000 a 2005, passou de 577,33 ha para 850,58 ha, com expansão principalmente no entorno das áreas já urbanizadas, ou seja, houve ampliação das área urbanizada nas regiões límitrofes do território.

Conforme demostram as imagens analisadas, observa-se que recentemente esse processo de dispersão urbana e industrial vem diminuindo e sendo substituído por um processo de adensamento urbano desse território por usos ligados a economia moderna, o que vem alterando as características morfológicas desse tecido urbano. 


\subsection{Município de CAJAMAR.}

\section{População e Território:}

População estimada em 2018: 72 mil habitantes.

Crescimento Anual População 2010/2018: 2,05 \% a.a.

Área: 131,39 km2.

Densidade demográfica 2016: 550,19 hab./km2.

Fonte: Dados fundação SEADE- http://www.imp.seade.gov.br. Acessado em 20/02/2018.

Pertencente à região metropolitana de São Paulo, faz divisa com Jundiaí ao norte, Franco da Rocha e Caieiras a leste, a capital a sudeste, Santana de Parnaíba ao sul e Pirapora do Bom Jesus a oeste.

Sua origem e formação se devem a presença de minérios em suas terras que abasteciam a fábrica canadense, Companhia Brasileira de Cimento Portland, instalada na década de 1920, ao lado da Estrada de Ferro Santos-Jundiaí, na região de Perus.

Ao longo da ferrovia se formaram núcleos populacionais, ocupados pelos trabalhadores das minas e da fábrica de cimento. Nesse período Cajamar era apenas um lugarejo localizado em região montanhosa, denominado Agua-Fria e pertencente ao município de Santana de Parnaíba.

Incorporava a população dos distritos de Jordanésia e Polvilho, tornando-se município autônomo apenas em 1959. Cajamar é cortada pela rodovia Anhanguera, que conecta esses dois distritos localizados um de cada lado do município.

Além de ser um importante elemento de povoamento e atração para o município, a via Anhanguera funciona como integração entre esses núcleos, o que manteve a unidade territorial nos movimentos pró-emancipação administrativa.

Conforme dados, IBGE Cidades-Cajamar, sem a rodovia, o distrito de Jordanésia provavelmente seria anexado ao município vizinho de Jundiaí e conseqüentemente Cajamar não teria condições de expansão territorial e estrutura econômica para se tornar autônoma.

Devido a sua proximidade com a capital, seu desenvolvimento foi impulsionado, principalmente após a instalação dos ramais Gato Preto e Água Fria da Estrada de Ferro Perus-Pirapora e, sobretudo, pela presença de minério em suas terras, atraindo indústrias de médio porte para a região ( Fundação SEADE - Cajamar História). 
Atualmente, predominam na região diferentes formas de uso e ocupação do solo e as principais atividades econômicas do município são: extração de madeira (silvicultura), mineração (em especial calcário, brita e filitos), indústria de alimentos, metalúrgica, cosmética e química.

A partir de 2000, a indústria logística passou a se instalar no município, ao longo do eixo da Via Anhanguera, produzindo gigantescos galpões industriais, e forte impacto territorial.

Devido ao seu patrimônio natural composto por remanescentes da Mata Atlântica, tem grande importância do ponto de vista ambiental. Desde 1984 seu território foi inserido em uma Área de Proteção Ambiental - APA, criada pela Lei Estadual oㅜ 4.055 de 1984. Além disso, é integrante da RBCV - Reserva da Biosfera do Cinturão Verde da Cidade de São Paulo, declarada pela UNESCO em 1994, abrangendo 73 municípios.

Atualmente, problemas ambientais são enfrentados por Cajamar devido a sua exploração mineral e vegetal, à implantação de serviços de infraestrutura, e à expansão urbana.

Fruto de um processo migratório desordenado, parte da sua população vive em condições de moradia precárias, em áreas invadidas, desmatadas e sem urbanização, Além disso, sofre impacto das suas ocupações recentes relacionadas com os avanços da reestruturação produtiva; da redução do emprego e da ausência de um planejamento urbano e econômico que promova o desenvolvimento sustentável do município.

Devido a sua localização na margem esquerda da rodovia Anhanguera (sentido norte), e separado dos demais municípios por Jundiaí, Cajamar é o município que menos se integra territorialmente com os demais analisados, que se localizam contiguamente na mesma margem direita da rodovia Anhanguera (sentido norte).

Embora também seja atravessado pela Via Anhanguera, não se desenvolveu ao longo dos mesmos eixos históricos, que estruturam os demais municípios, como a estrada da Boiada e a linha Férrea da Companha Paulista.

Porém, como os outros municípios, por possuir localização estratégica, e relacionar-se diretamente com a rodovia Anhanguera, sofre os mesmos impactos territoriais resultantes dos avanços dos processos de reestruturação produtiva, no século XXI.

Conecta-se fortemente com os municípios de São Paulo, Campinas e Jundiaí, e por sediar algumas empresas de peso como a Natura, trabalhadores de todo o vetor noroeste se deslocam diariamente para o município de Cajamar.

A seguir imagens aéreas do tecido urbano dos quatro municípios abordados. 

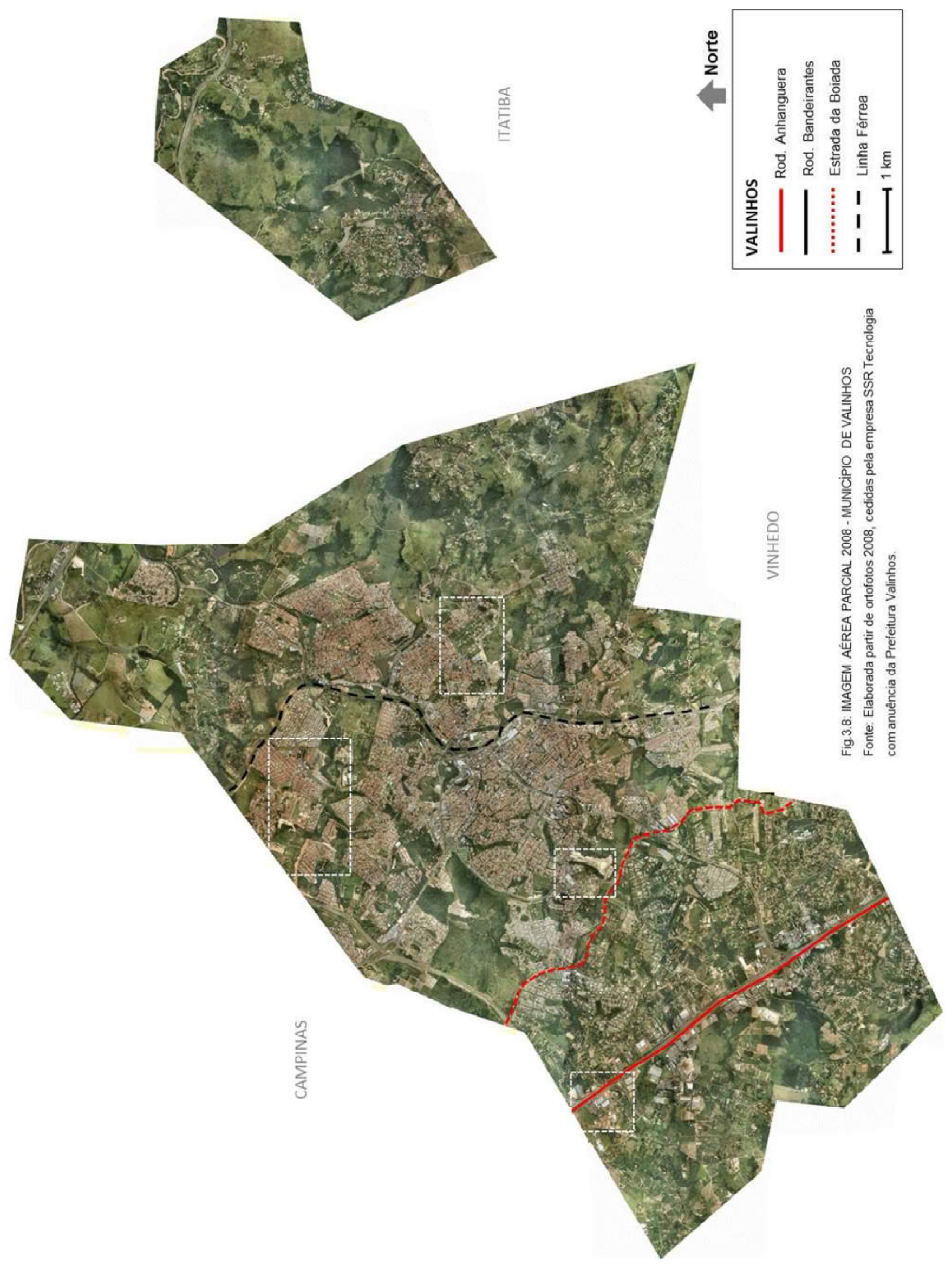

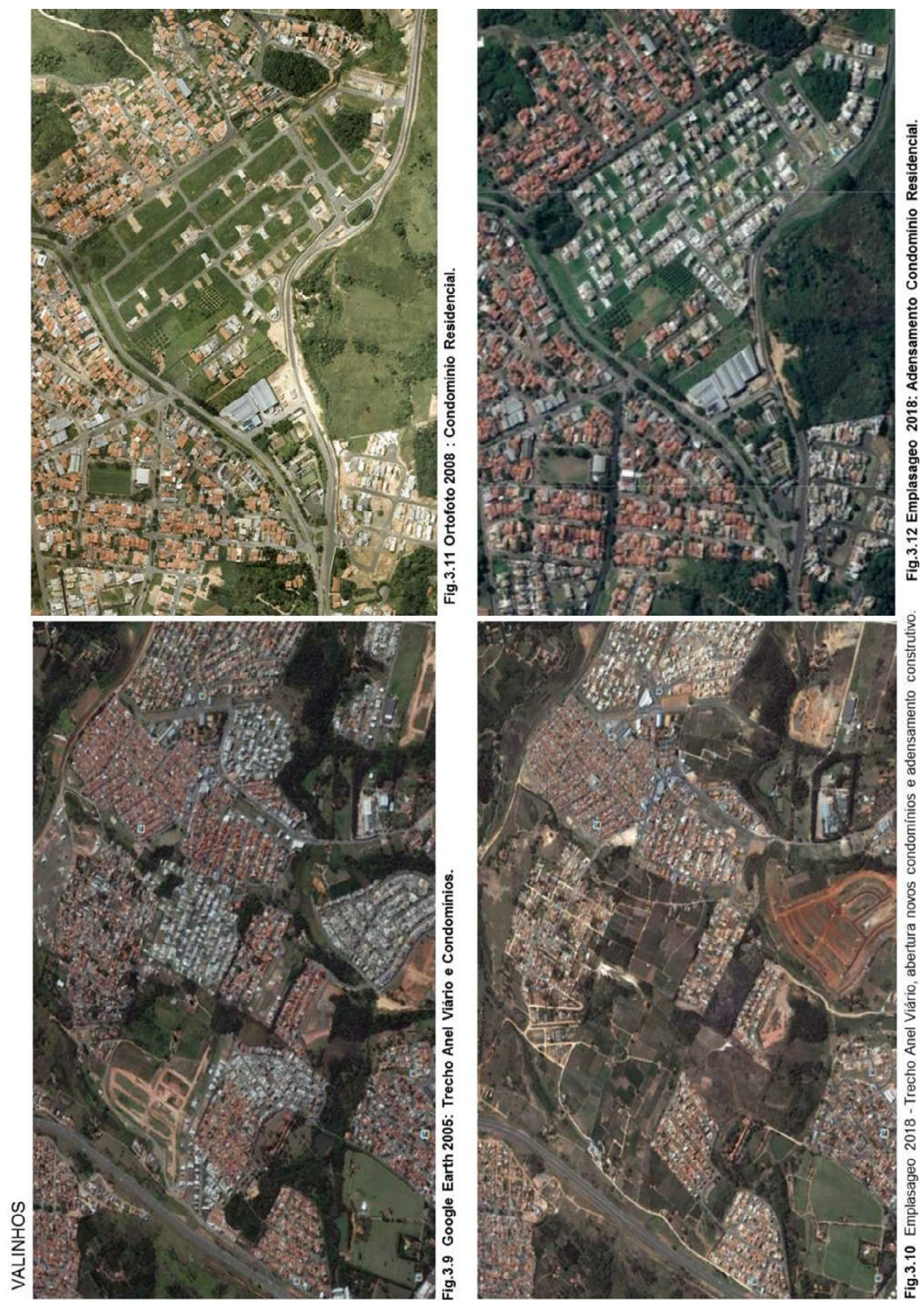

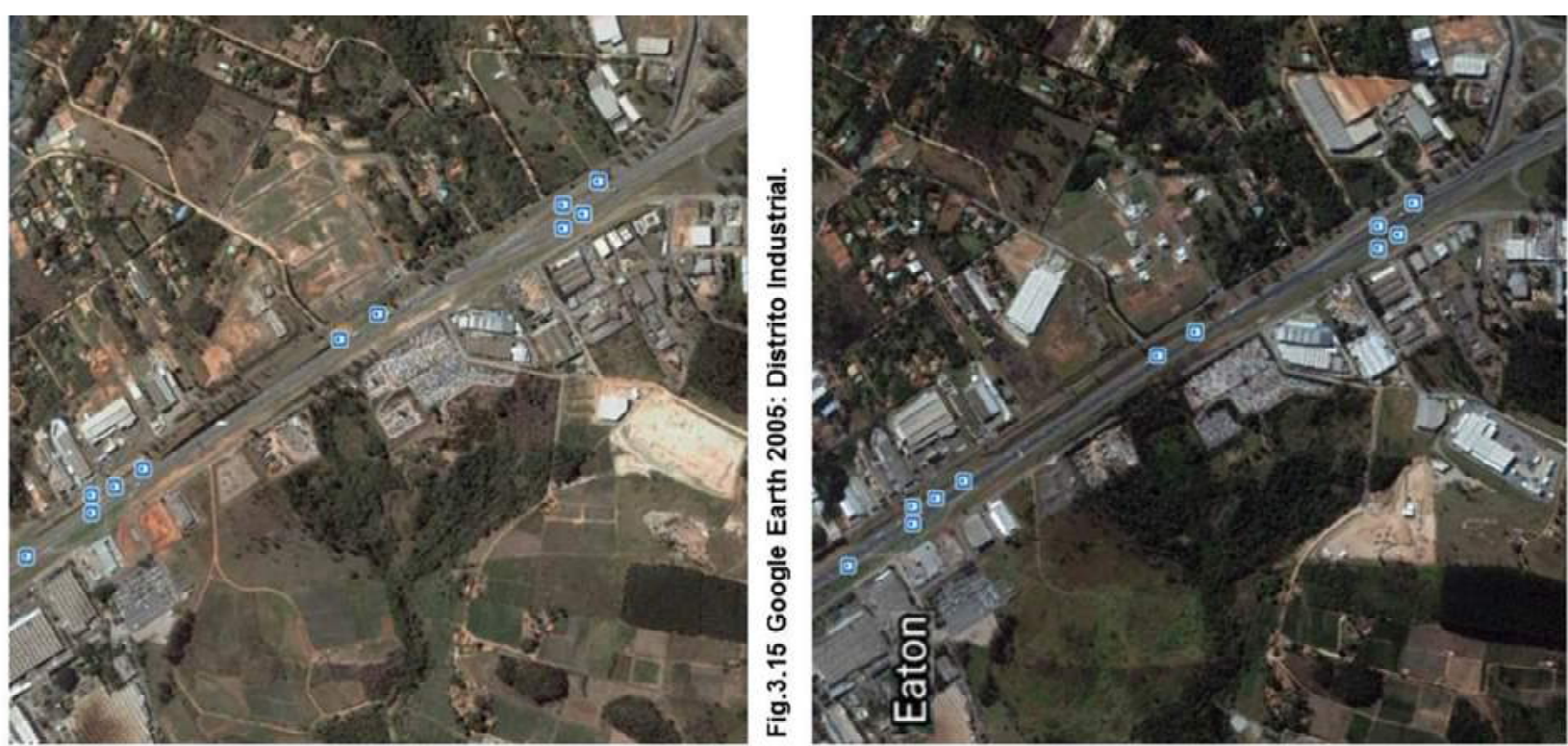

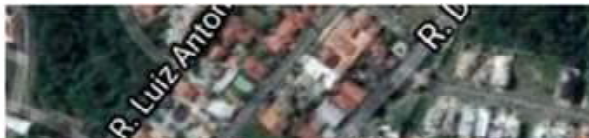

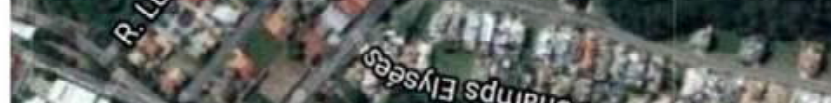

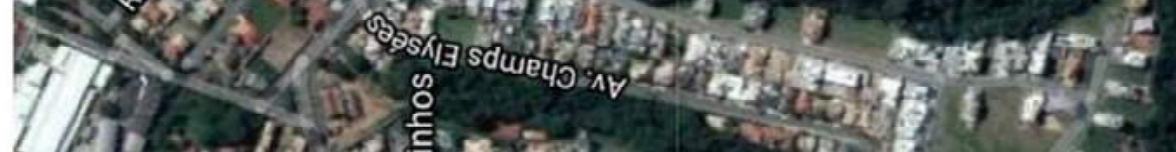

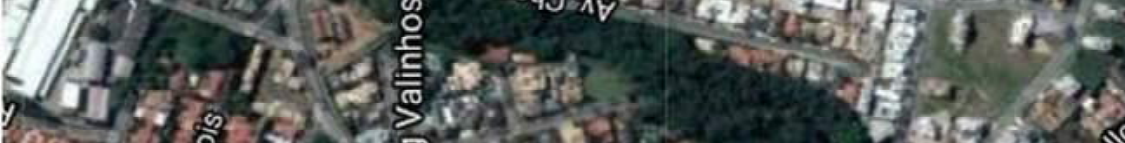

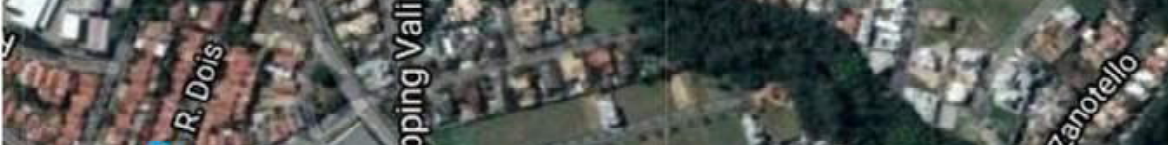

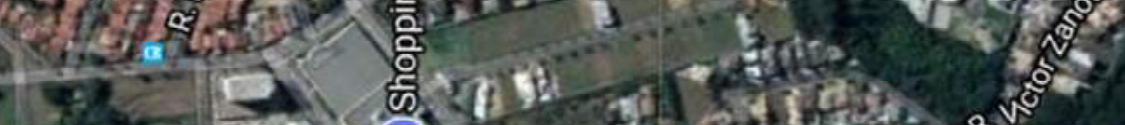
(12) C20 (d)

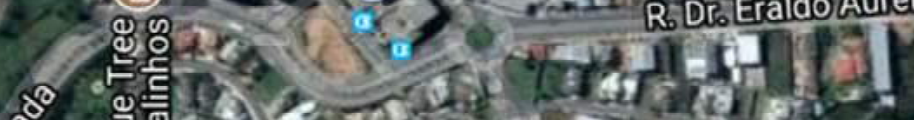
क s.

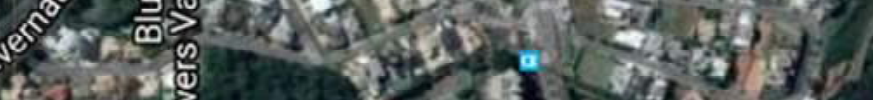

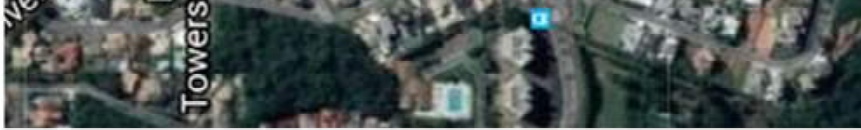

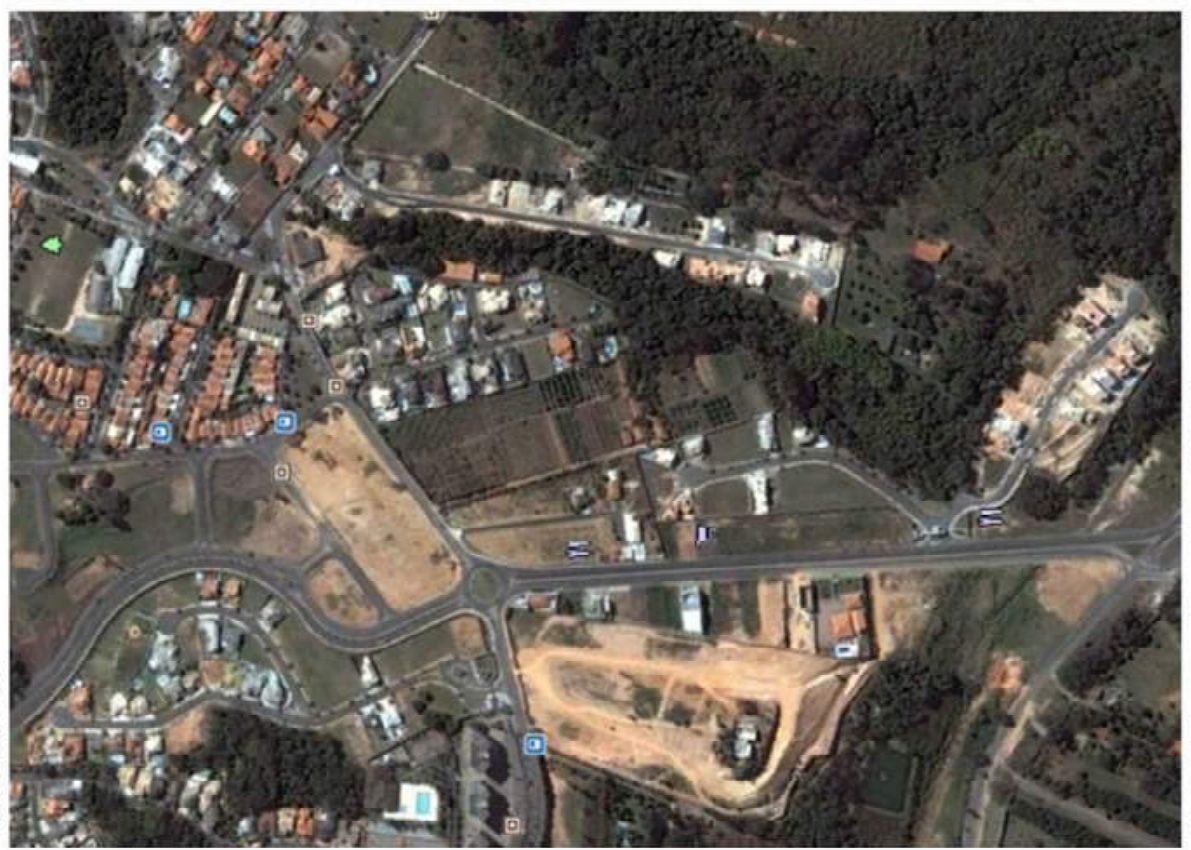

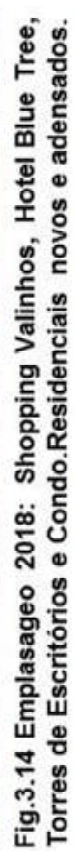
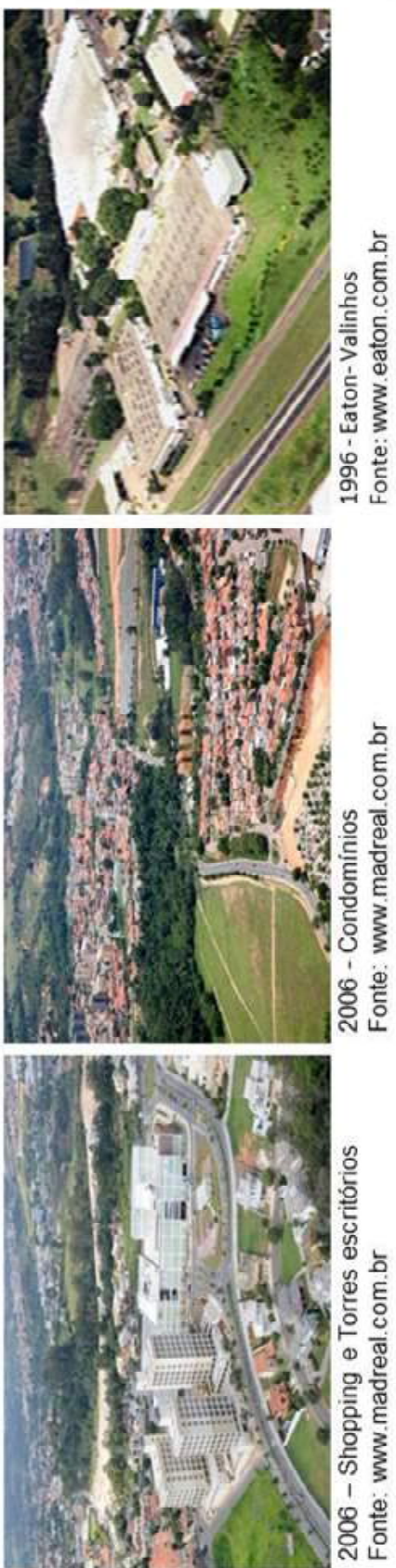


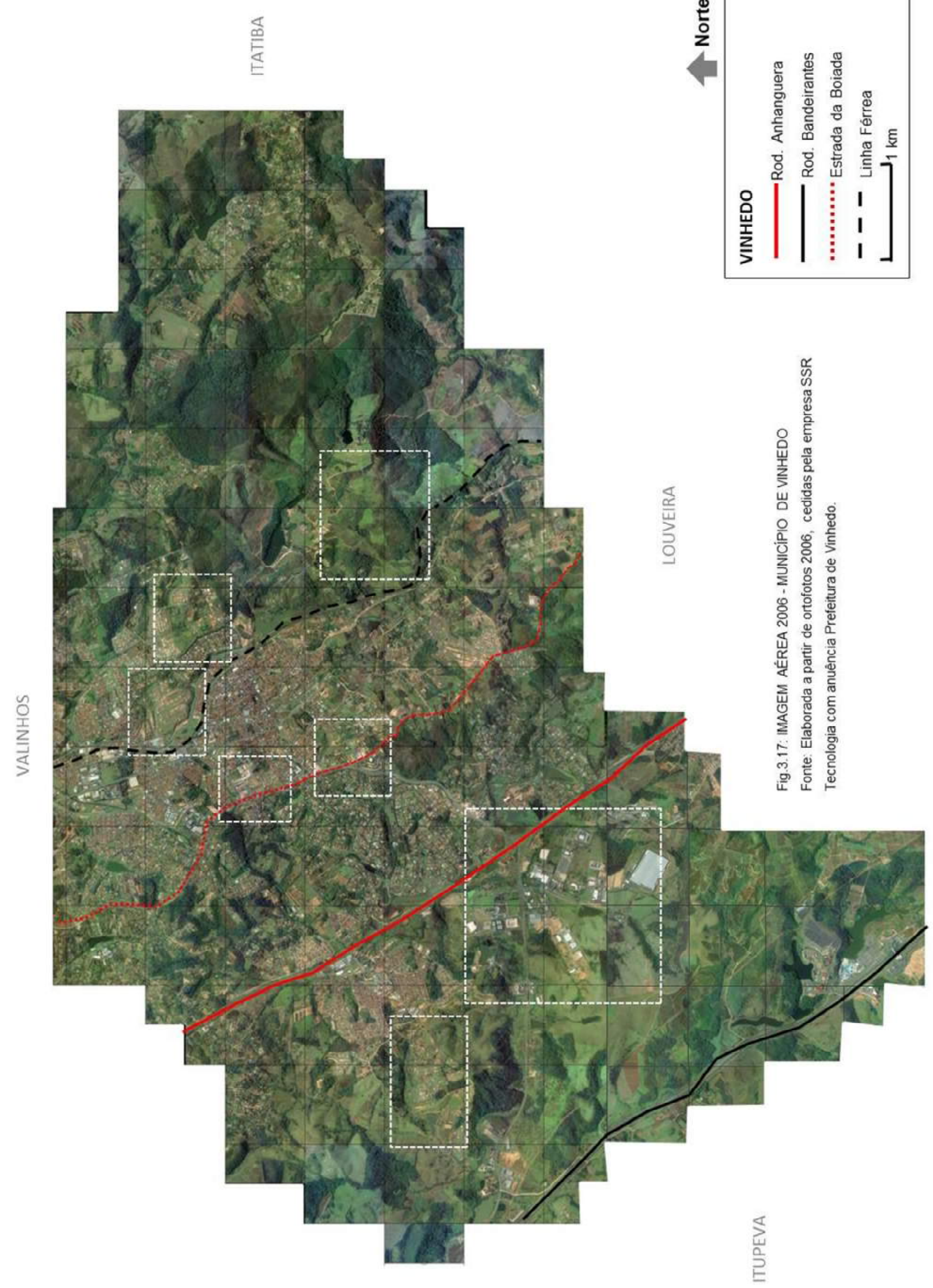



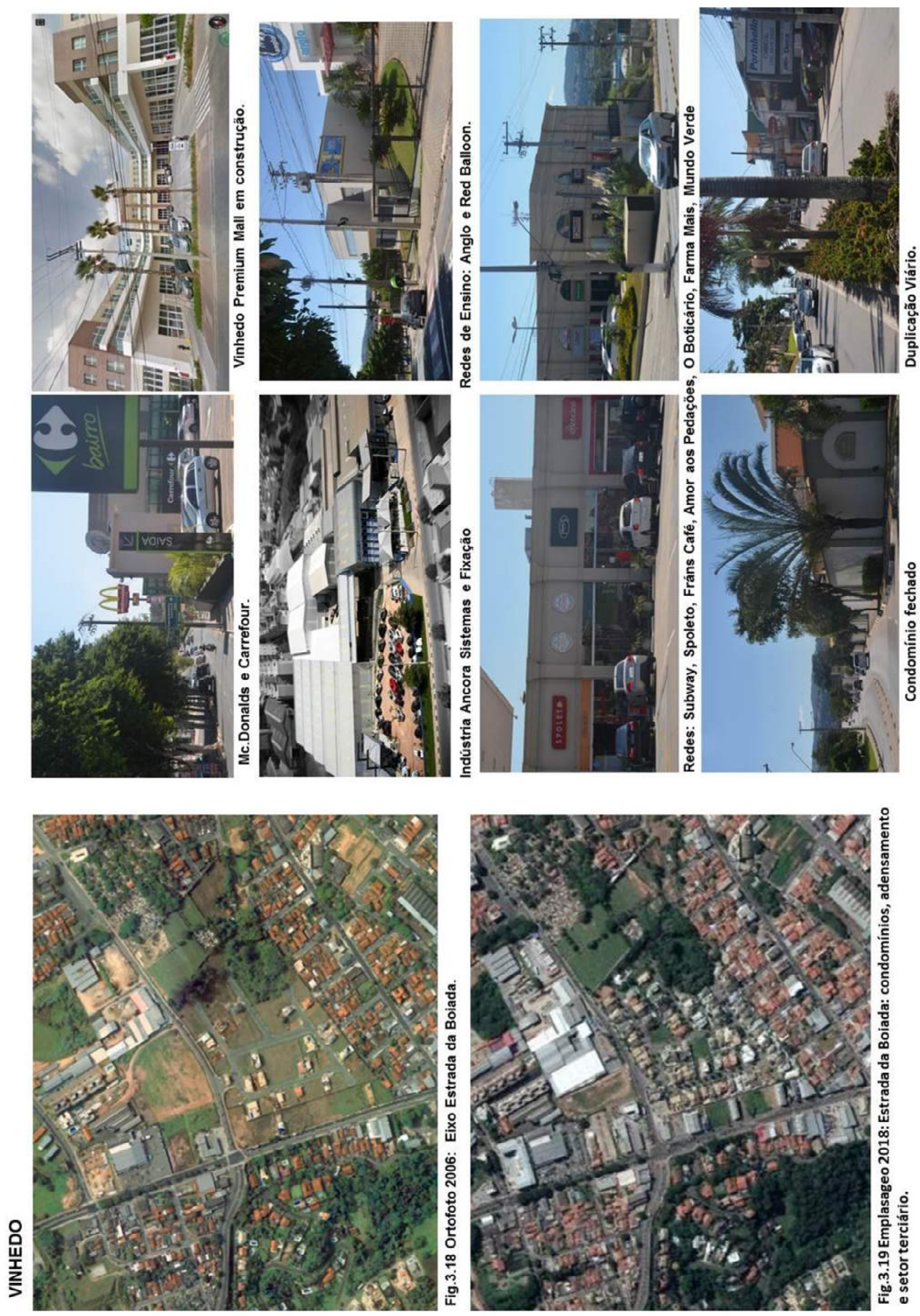

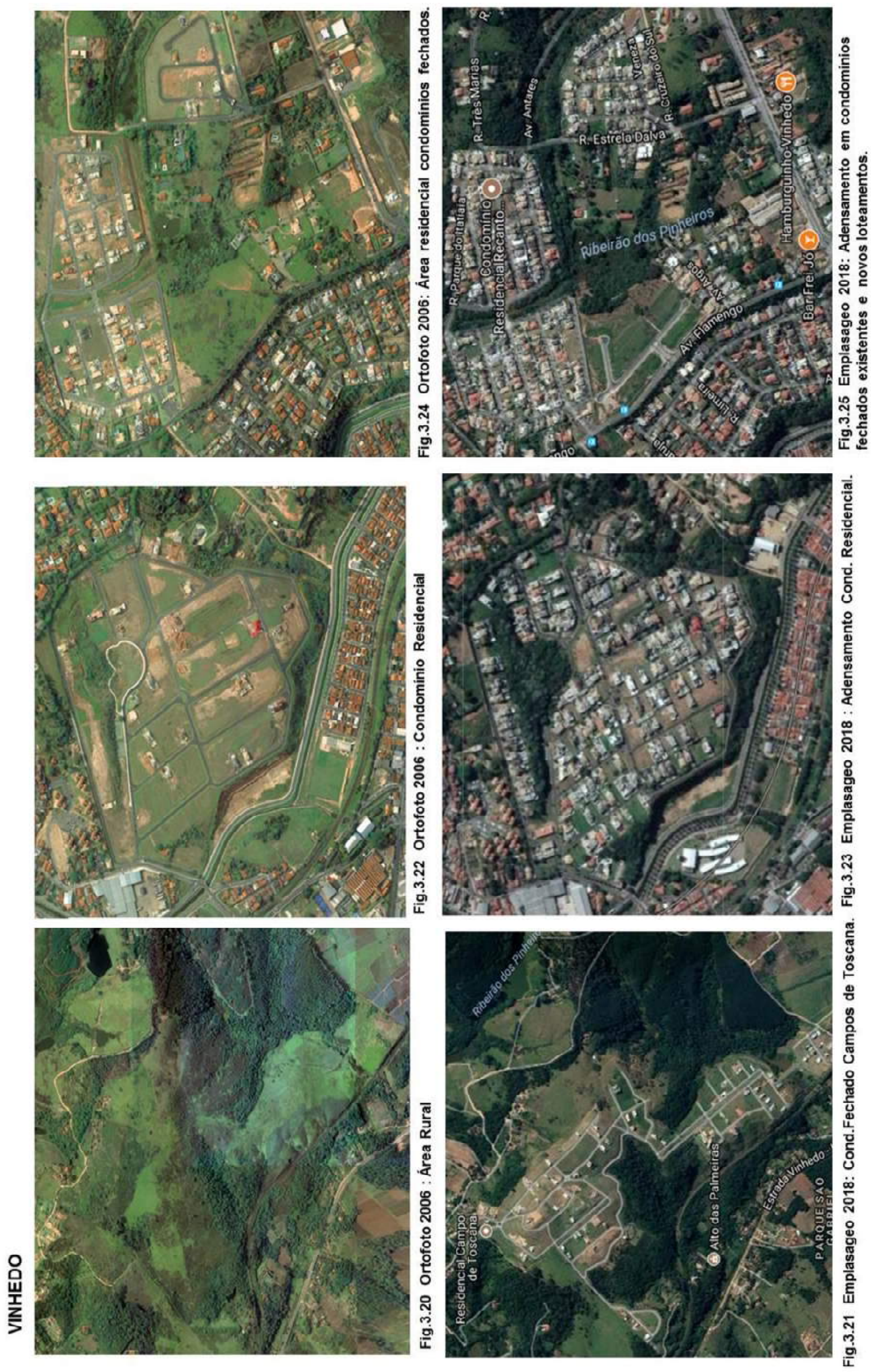

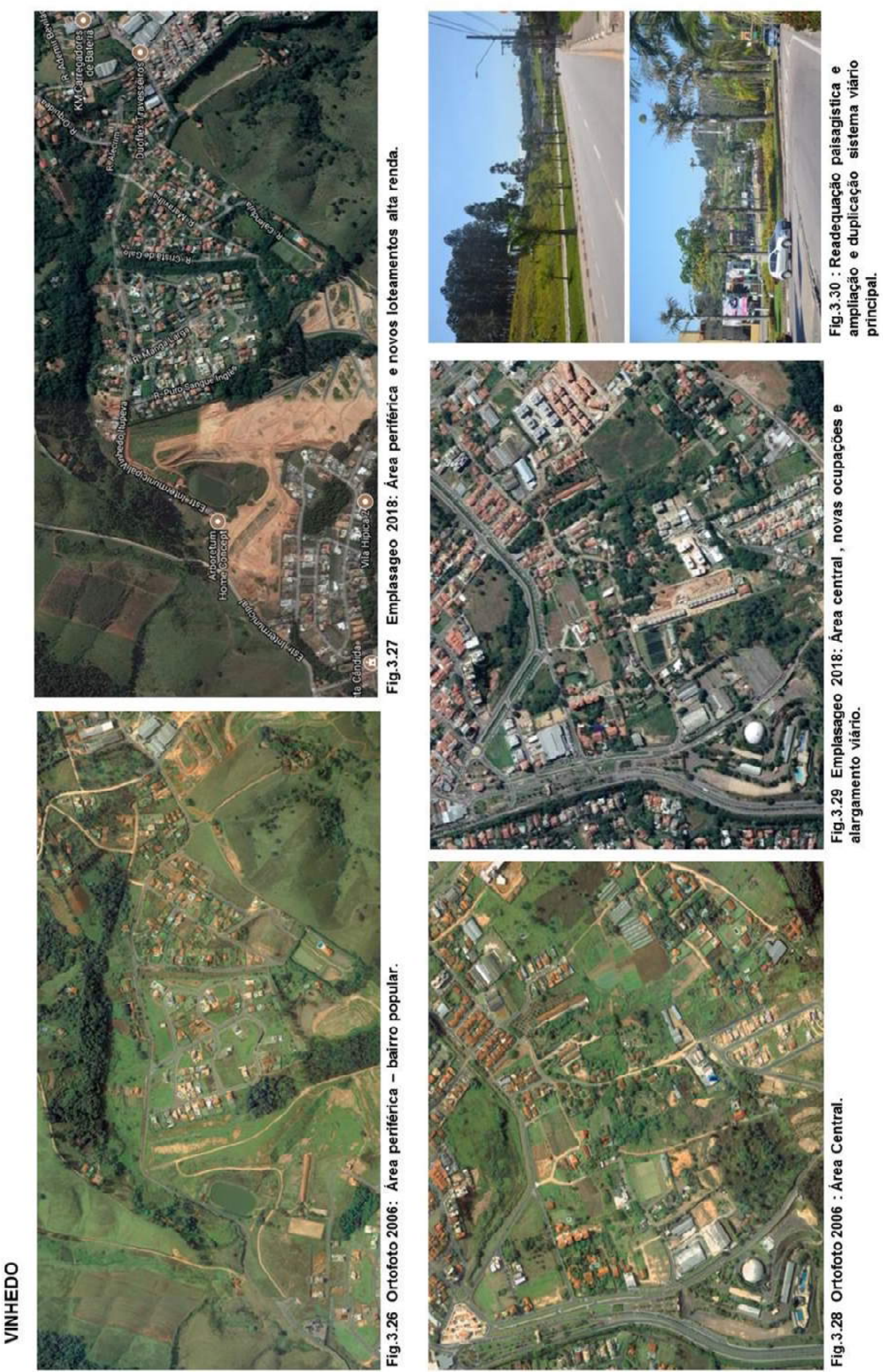

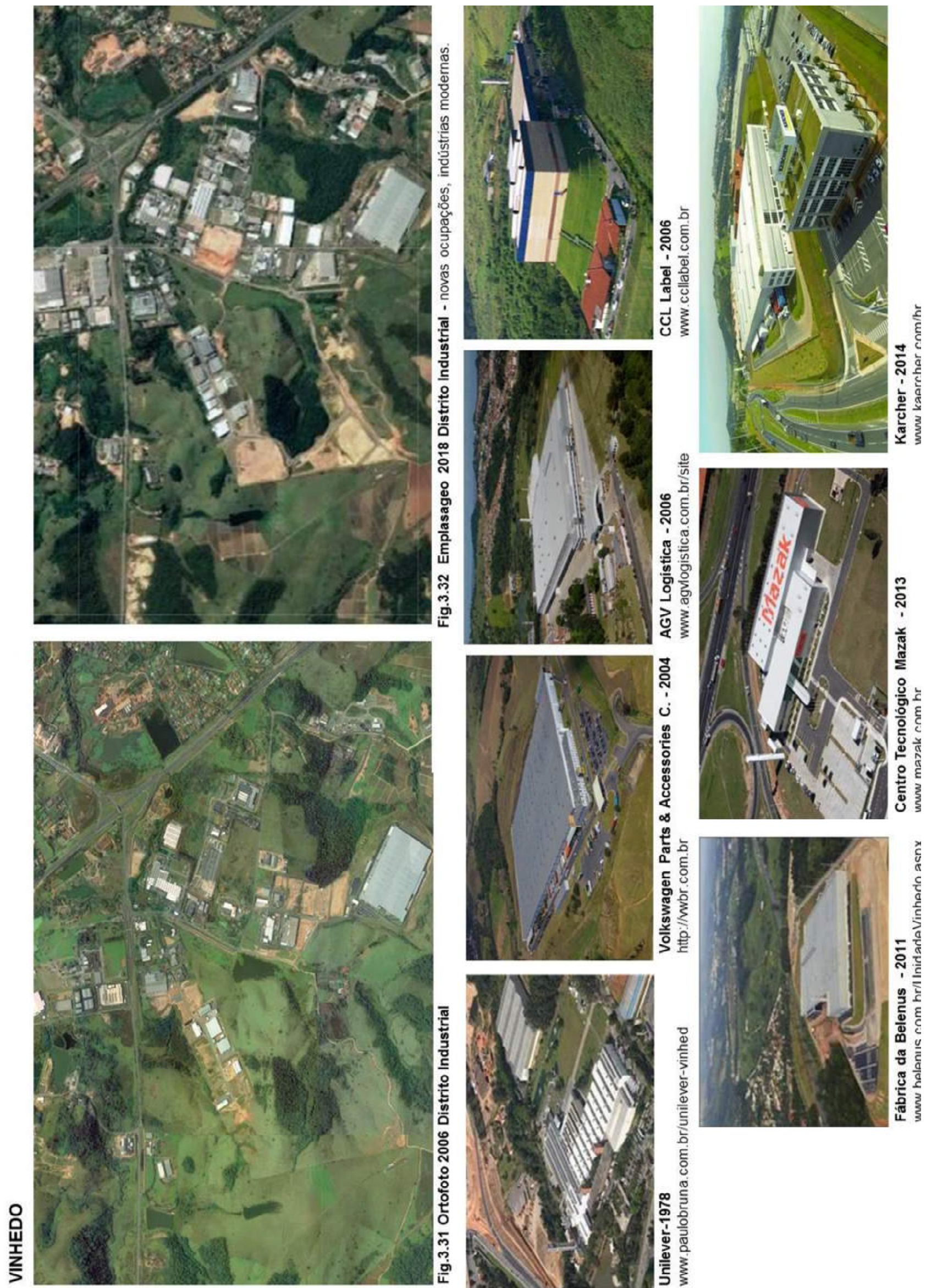


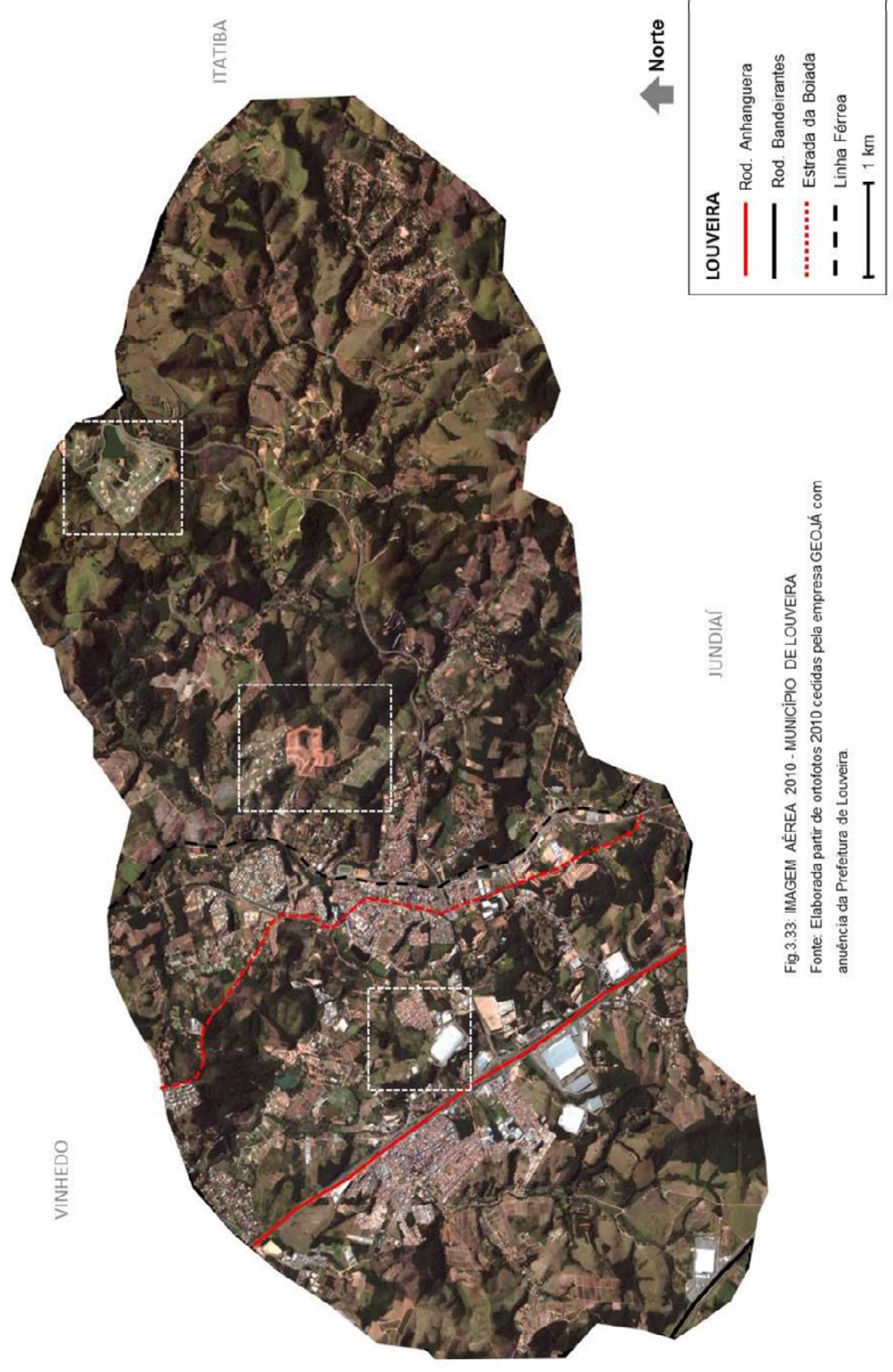



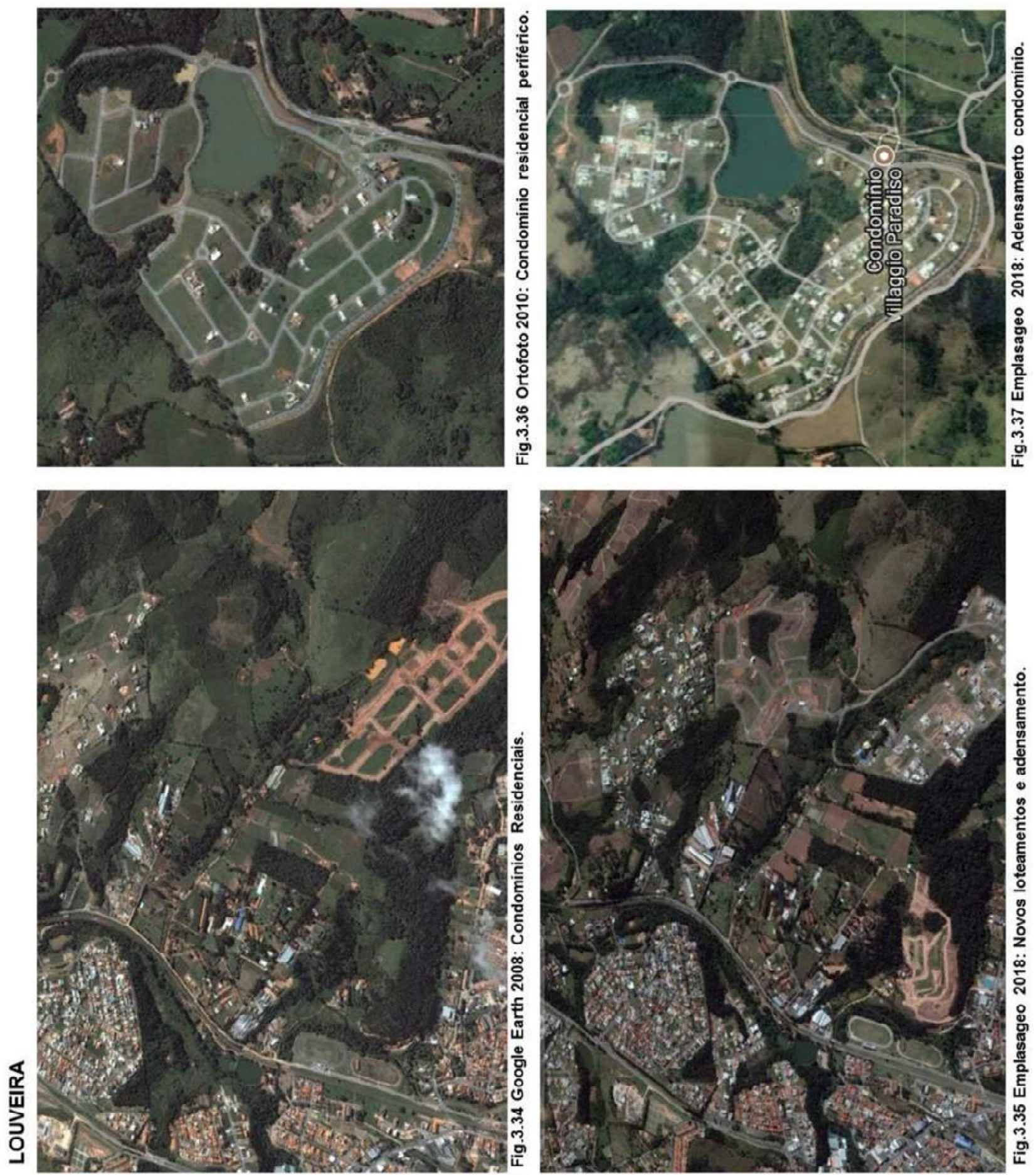

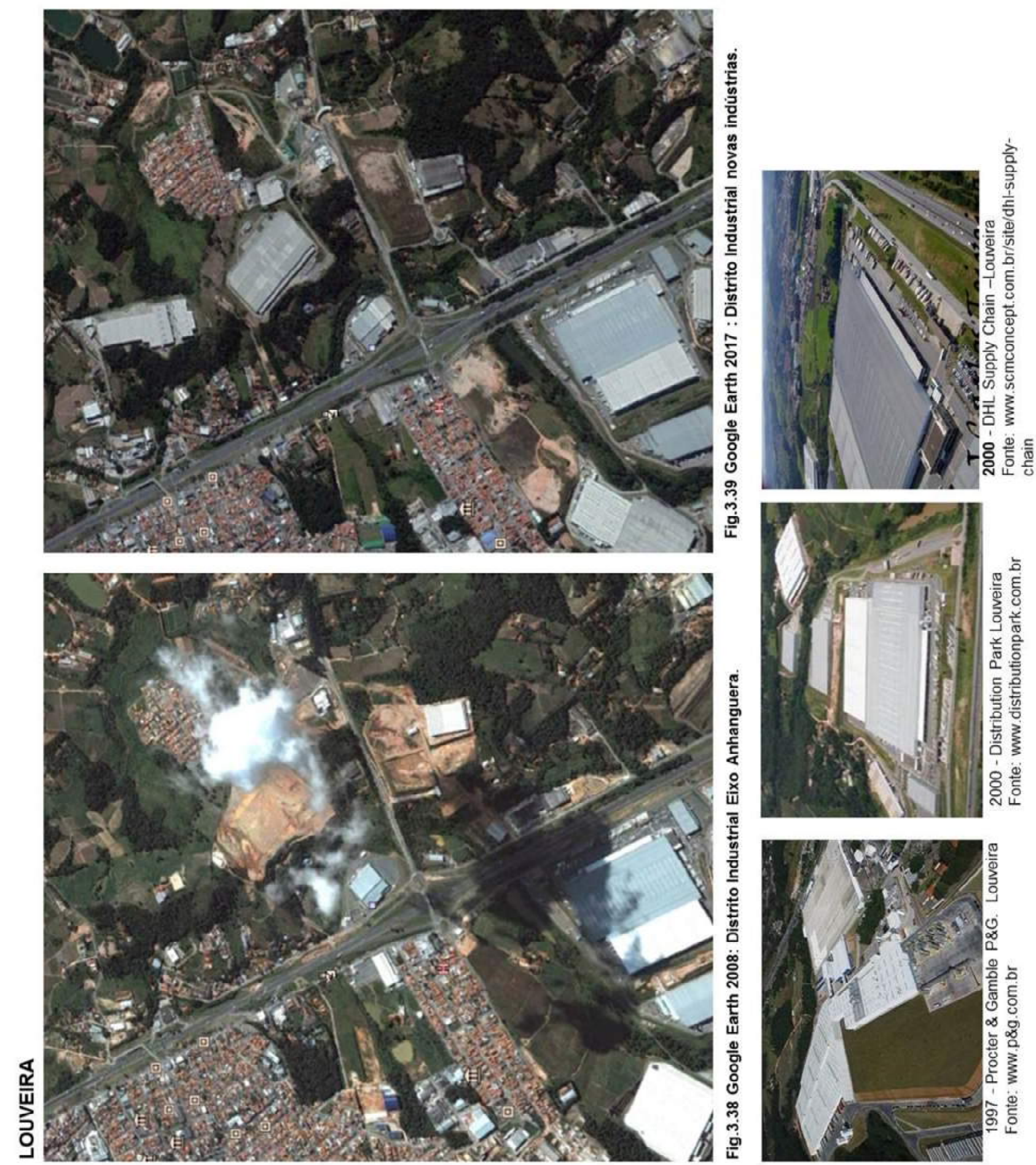


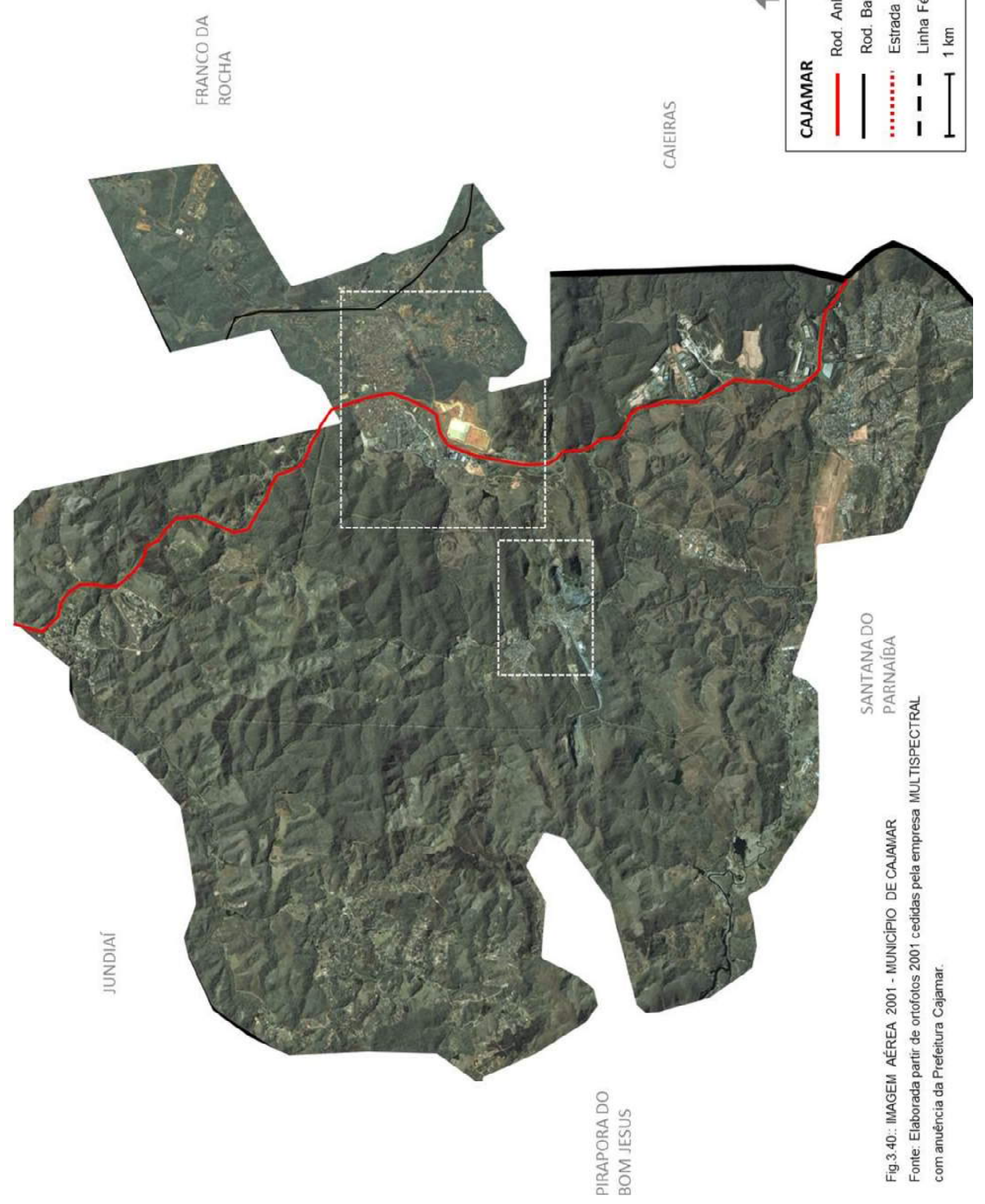



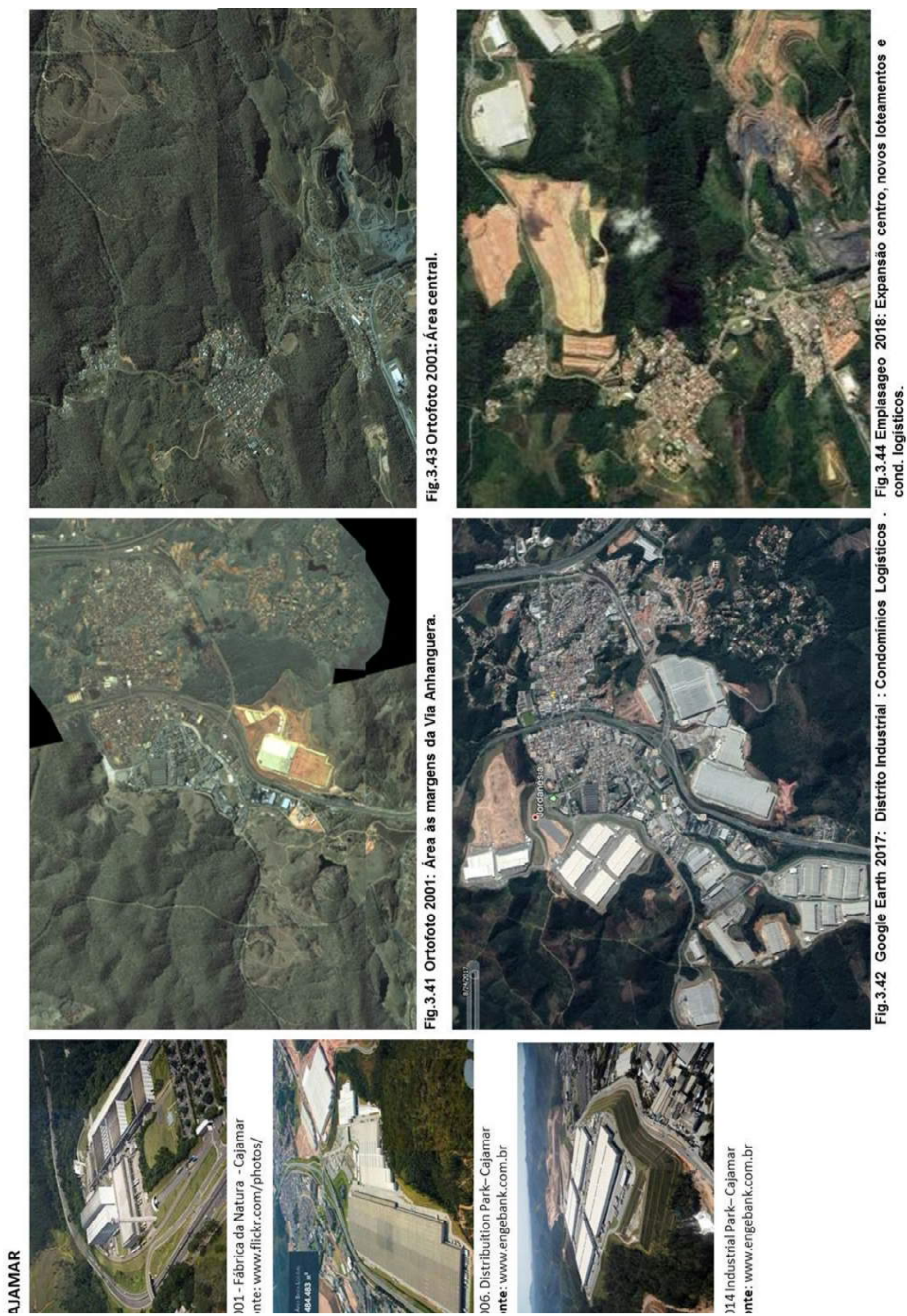
A análise das imagens aéreas constatou uma forte integração territorial entre esses municípios, e a presença de tecidos urbanos diferenciados conforme o eixo, ou o período, em que a ocupação ocorreu. Tecidos mais regulares e densamente ocupados ao longo da via férrea e mais dispersos, ocupando grandes glebas, na medida em que se expandem em direção a estrada Boiada, depois para Anhanguera, e a seguir para rod. Bandeirantes.

Devido à intensificação das dinâmicas de dispersão, agora mais relacionadas à economia moderna, partir do século XXI, observa-se a transformação de um tecido urbano disperso e esgarçado, constituído de porosidades, por um tecido marcado mais por continuidade territorial do que vazios urbanos.

Ou seja, integram-se os fragmentos dos territórios dispersos vigentes no século XX, e constitui-se, no novo século, um novo território metropolitano, marcado por continuidade e integração territorial e que se desenvolve ao longo dos seus eixos históricos.

Além de um novo arranjo urbano, a seguir veremos que relações espaciais e fluxos de deslocamentos são também intensificados no vetor noroeste e em outros corredores viários, constituindo novos arranjos produtivos, dentro e fora da macrometrópole paulista.

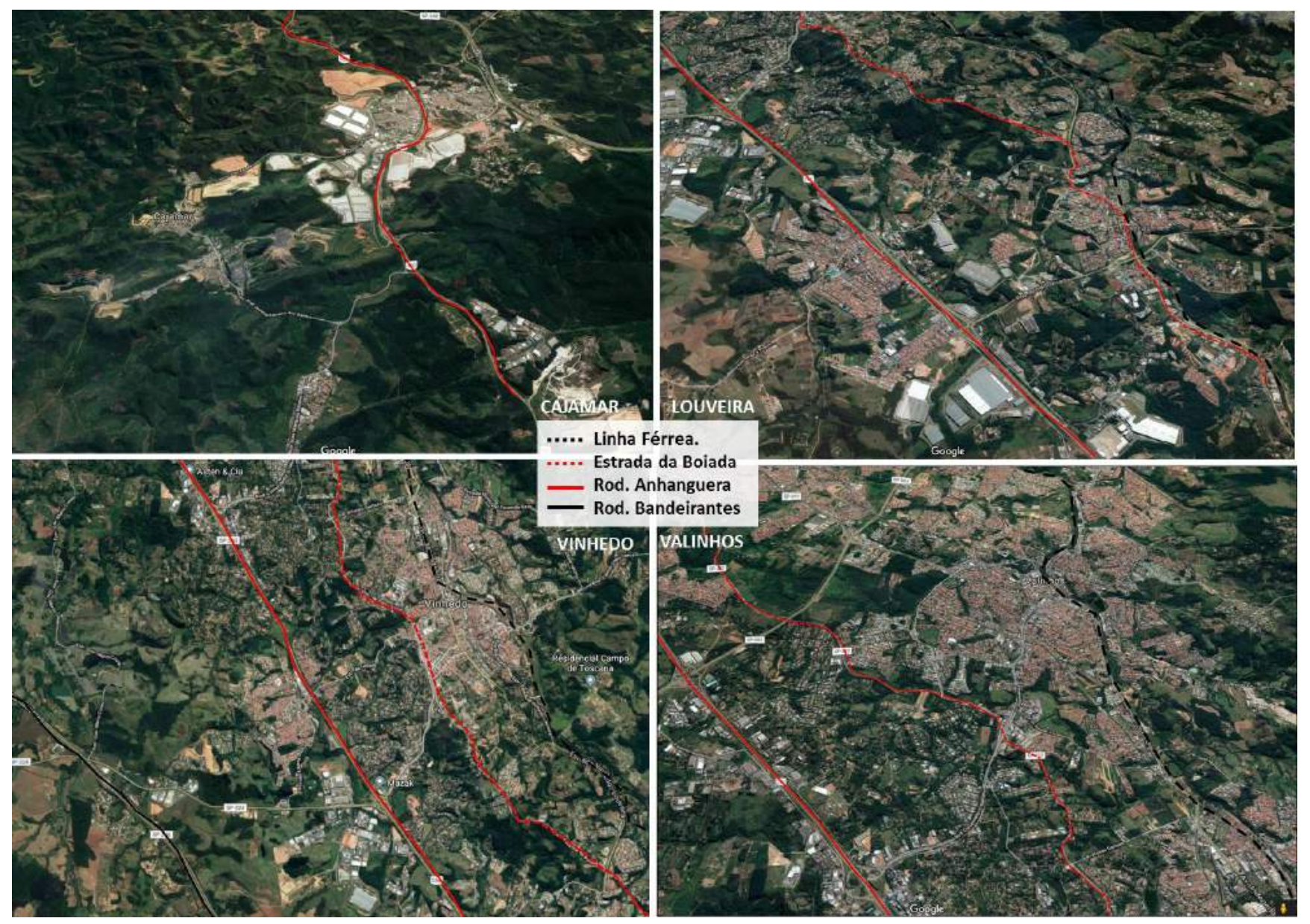

Figura 3.45: Desenvolvimento urbano ao longo de eixos históricos: Cajamar, Louveira, Vinhedo e Valinhos. Fonte: Elaborado a partir de base google maps. Situação sem escala. 
CAPÍTULO 4

\section{Escala Regional: Integração e Fragmentação do Espaço Nacional.}

Dados econômicos e de mobilidade, configuram novos arranjos produtivos, a ascenção do vetornoroeste, e a transição da economia paulista da escala metropolitana para a escala macro-metropolitana. Decorrente deste processo observa-se 0 fortalecimento e a integração de novas centralidades, e o surgimento de novas dimensões espaciais, que extrapolam limites instituídos. Estruturadas por corredores de riqueza que fragmentam o espaço, requerem uma forma de gestão mais abrangente e integrada. 


\subsection{Alteração dos Fluxos da Economia Paulista e Novos Arranjos Espaciais.}

Como visto, no século XXI, observa-se o desenvolvimento urbano e a ascensão do vetor noroeste como eixo de atração e concentração de usos ligados à economia moderna, com ênfase para o setor de serviços e os condomínios residenciais.

Além da alteração da morfologia urbana desses municípios, impactados pelas novas dinâmicas de dispersão, a imagem abaixo, mostra a intensificação dos deslocamentos diários para trabalho e estudo, acima de 20.000 pessoas, no vetor noroeste paulista. A integração deste território com a capital através do aumento dos fluxos de deslocamentos pendulares fortalece relações sociais e econômicas mais abrangentes.

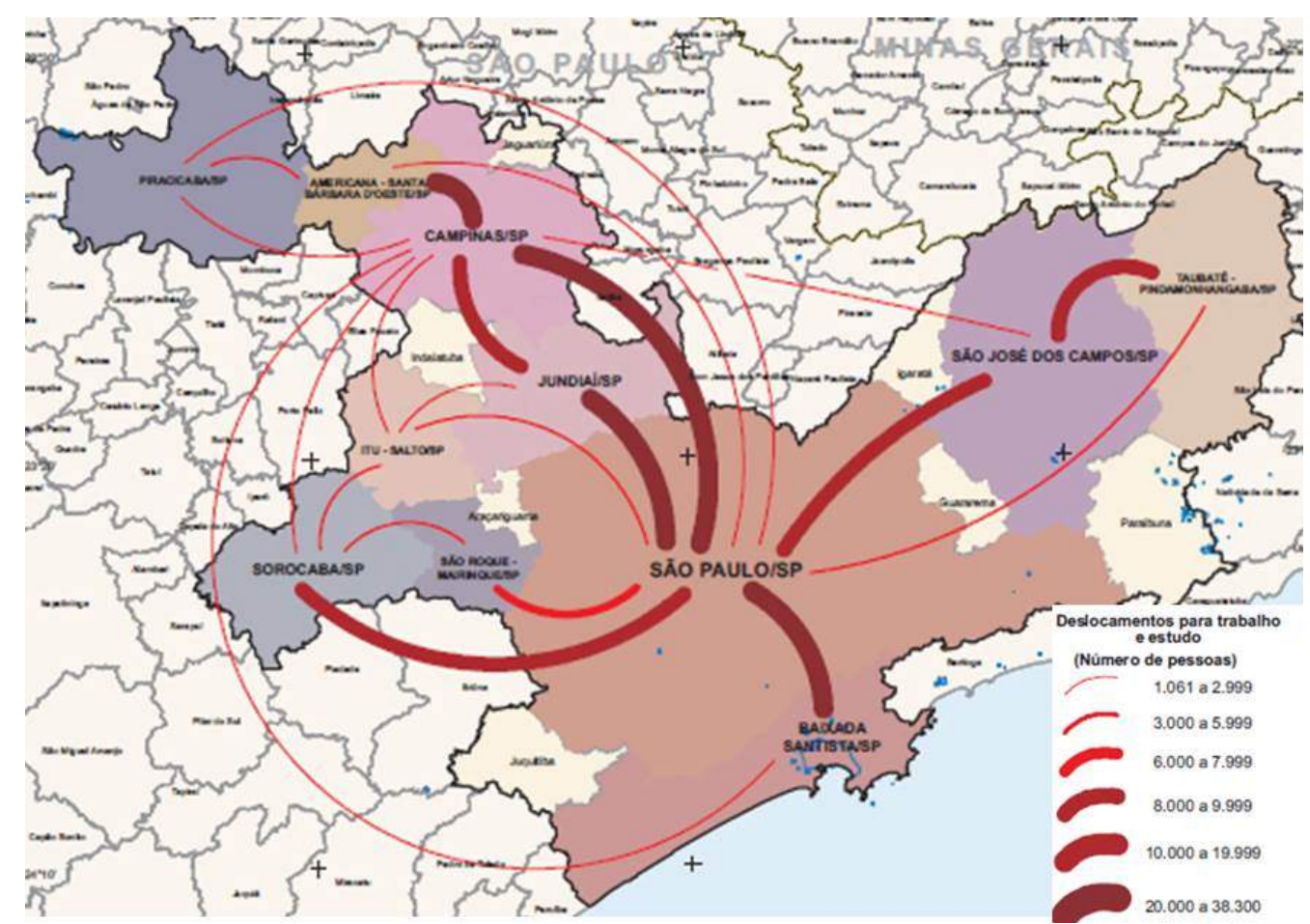

Figura 4.1: Intensidade e distribuição dos fluxos para trabalho e estudo. Fonte: IBGE (2016).

Cunha (2013), demonstra a importância de análises pendulares, para revelar o grau de integração e complementariedade existente entre territórios dispersos, e que atualmente, relações socioeconômicas ampliadas, ocorrem em dimensões espaciais também mais ampliadas.

Além disso, o autor mostra que nos últimos dez anos, apesar da taxa anual de crescimento da população de $1,1 \%$ nas regiões metropolitanas paulistas, a taxa de crescimento dos movimentos pendulares entre as regiões que compõem a Macrometrópole Paulista foi de $8,7 \%$ ao ano. Isso revela a maior integração desse território. 
Os movimentos pendulares, deslocamentos diários de pessoas entre residência e trabalho ou estudo, estabelecem vínculos territoriais que extrapolam limites administrativos e são fundamentais para identificar a integração ou desintegração de novos arranjos produtivos ou territórios metropolitanos, como também planejar sua reestruturação, através de um planejamento mais abrangente e menos excludente.

Esse contínuo processo de interação econômica e social entre os territórios da R.M. de Campinas e a R.M. de São Paulo, através de um intenso deslocamento rotineiro, acima de 20.000 pessoas, que é acompanhado de um desenvolvimento econômico notável, tem como consequência uma mudança da geografia da economia paulista.

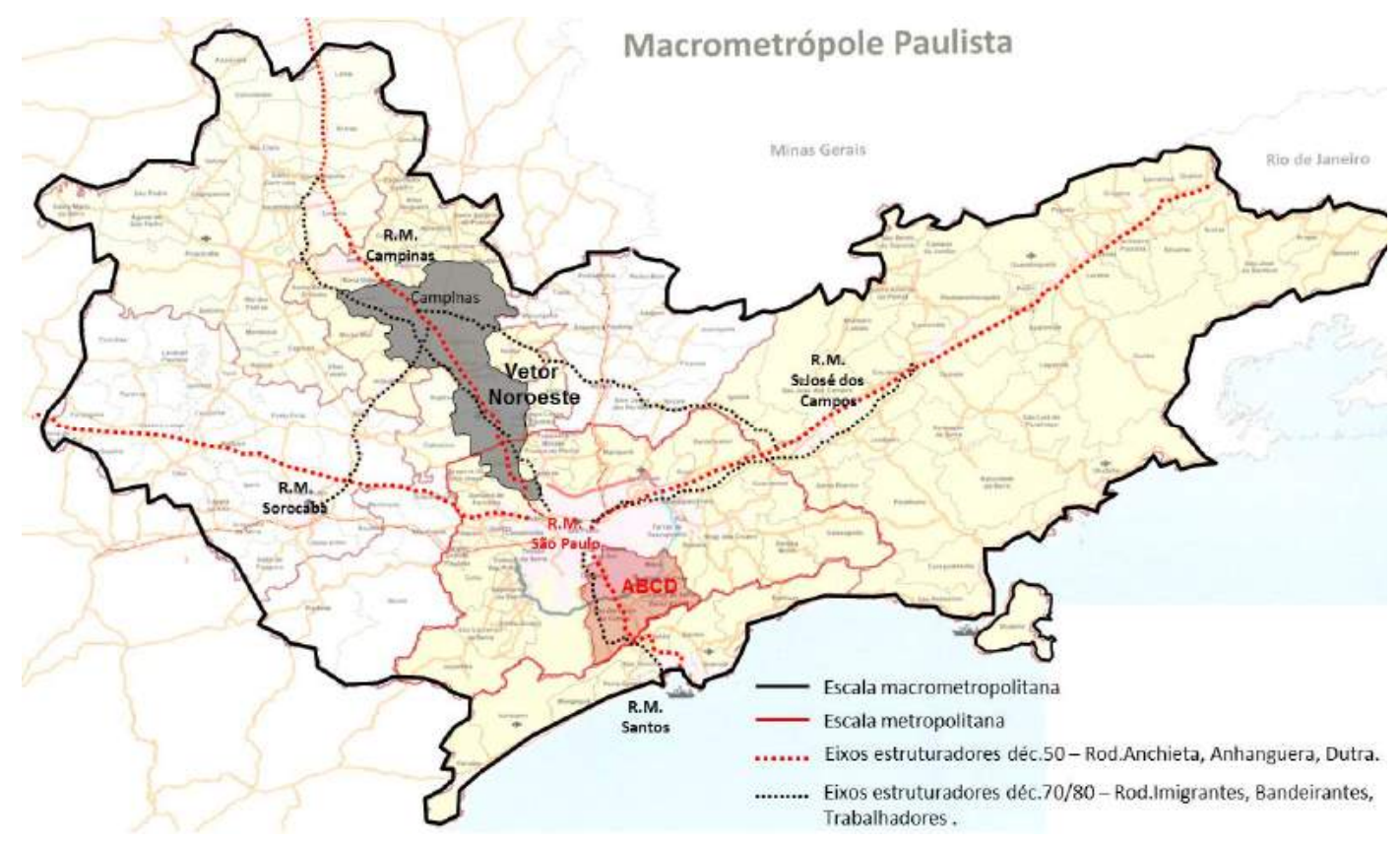

Figura 4.2: Vetor Noroeste inserção na macrometrópole paulista $X$ ABCD inserção metropolitana. Fonte: Elaborado a partir de base Emplasa - Empresa Paulista de Planejamento Metropolitano.

Cabe lembrar que a metrópole paulista apresenta dois modelos espaciais distintos, resultantes do modo de produção capitalista. O primeiro, mais precário, resultado do sistema produtivo industrial, e o segundo, vinculado ao processo global de reestruturação produtiva, que estabelece novos critérios de funcionamento da indústria moderna .

Esses modelos se refletem na produção espacial de duas importantes e históricas regiões produtivas do estado de São Paulo, uma, inserida em um contexto industrial e metropolitano, e estruturada a partir das décadas de 1950/1970 pelo sistema rodoviário Anchieta/Imigrantes (ABCD Paulista). E a outra, inserida em um contexto pós-industrial e regional, e estruturada a partir de 1970, pelo sistema de rodovias AnhangueraBandeirantes (vetor noroeste paulista- trecho São Paulo-Campinas). 
A evolução técnica e estratégica desses dois sistemas rodoviários - Anhanguera/ Bandeirantes e Anchieta/Imigrantes, serviu de suporte espacial ao desenvolvimento econômico dessas duas importantes regiões do Estado.

Ao mesmo tempo, o desenvolvimento urbano ao longo desses eixos produtivos permitiu que formas urbanas estendidas se manifestassem no território. Esse processo tem gerado o aumento da mobilidade, a formação de novas centralidades e mudanças na escala territorial da capital, que se transforma em metrópole na década de 1970, e em macrometrópole na década de1990.

Conforme Klink (2001), o grande $A B C D$ é uma região metropolitana com identidade claramente industrial devido à presença das grandes matrizes automobilística e química, implantadas no período de nacional-desenvolvimentismo (a partir de 1950), dentro do contexto do regionalismo brasileiro em que o governo federal visava inserir os interesses das classes periféricas no espaço nacional.

Em razão da sua complexa estrutura econômica, essa região vem sofrendo impactos econômicos negativos, devido aos processos de reestruturação produtiva.

Segundo Somekh (2005), o surgimento de grandes vazios ociosos ou subutilizados em cidades como o ABCD Paulista, cujo crescimento se amparou na indústria de transformação, foi um dos impactos negativos provocados pelo processo global de reestruturação econômica. No início deste processo, discussões sobre recuperações de áreas industriais degradadas e sobre a produção da cidade compacta foram substituídas pela produção da cidade difusa, sem a devida atenção às questões ambientais e ao quadro industrial já instalado.

Ao contrário, o vetor noroeste da capital paulista, considerado um território disperso que se estende além dos limites metropolitanos, é caracterizado pela sua inserção nos processos globais de transformação sócio-econômica que têm início a partir de 1970.

A partir de 1990, é inserido no contexto da globalização e do novo-regionalismo, assumindo novas atribuições como geração de renda, emprego e política industrial para seu território, enquanto o Estado perderia espaço na condução das políticas macroeconômicas.

Conforme visto, o progresso desse vetor tem ocorrido em função de mudanças econômicas e necessidades produtivas, apoiadas por políticas públicas, que demandam novos padrões de mobilidade, que por sua vez, reconfigurando o espaço metropolitano e estruturando aos poucos uma nova dimensão espacial (EIGENHEER, 2011). 
A partir da abordagem de Reis (2006), busca-se compreender a conformação e a relação entre estas duas históricas regiões produtivas do estado de São Paulo: ABCD paulista $x$ Vetor Noroeste Paulista.

Segundo o autor, o processo de dispersão industrial ocorre ao longo do século $X X$, devido à substituição da dependência do carvão e das ferrovias, pelo uso da eletricidade e a construção de grandes rodovias. Na primeira fase deste processo os investimentos em equipamentos e a mecanização da indústria necessitaram grandes áreas para a instalação das fábricas gerando os bairros operários e a conformação das áreas metropolitanas dentre estas, o ABCD Paulista.

$\mathrm{Na}$ segunda fase desse processo, depois de 1970, as indústrias se dispersaram para áreas mais afastadas rumo ao interior e outros estados. A partir daí, as cidades médias paulistas como Campinas, Vale do Paraíba, Cubatão e Baixada Santista, Sorocaba, Jundiaí, passam a crescer mais do que a área metropolitana de São Paulo, configurando novos territórios dispersos.

Contudo, Harvey (1981) aborda a existência de um conflito no sistema capitalista, no qual a configuração de um novo espaço apropriado para a acumulação do capital de um período acontece em detrimento do abandono e destruição de antigos investimentos realizados no espaço construído, que se transformam em entraves econômicos ou em deseconomias de aglomeração, caso não sejam reestruturados.

Dentro desse contexto, dados econômicos do SEADE demonstram este processo de mudança da geografia e do padrão da economia paulista. Até o final do século $X X$, a economia paulista se concentra na capital e no ABCD Paulista e é baseada principalmente na indústria pesada automobilística. No novo século, observa-se seu deslocamento, dentre outras regiões, para o vetor noroeste da capital, estruturado pelo eixo Anhanguera/Bandeirantes, trecho São Paulo-Campinas ( EIGENHEER, 2017).

Conforme se observou no capítulo anterior, este eixo apresenta um tecido urbano cada vez mais ocupado por atividades relacionadas com o setor terciário moderno, produzindo expressivo impacto territorial e urbano, enquanto algumas antigas áreas industriais do $A B C$, providas de infraestruturas, foram esvaziadas.

Altera-se a paisagem das fábricas instaladas em quarteirões regulares com alta densidade, dentro das cidades do ABCD paulista, para um novo padrão de urbanização no Vetor Noroeste Paulista com implantação fragmentada e de baixa densidade. 
Conforme ANAU (2002), apesar da crise enfrentada nas décadas de 1980 e 1990, devido à globalização e à reestruturação produtiva, o pioneirismo do $A B C D$ nos processos de modernização industrial, entre 1950 a 1970, permitiu que ele mantivesse sua posição de liderança econômica territorial metropolitana do estado, atrás apenas da capital.

Contradizendo alguns autores, Anau (2002) afirma que o $A B C D$ não enfrentou um processo de desindustrialização como o ocorrido em Detroit, embora a terceirização dos seus processos produtivos tenha provocado a retração da sua base industrial, inclusive do setor automobilístico, bem como a queda no nível de emprego e a precarização das condições de vida da população de mais baixa renda.

Contudo, o que esta pesquisa demostra é que apesar da permanência da vantagem competitiva e econômica do ABCD durante o período de crise, as implicações decorrentes do seu enfrentamento ao processo de restruturação produtiva, permitiram que no novo século, outra região, se destacasse na liderança econômica do estado: o vetor noroeste.

A pesquisa analisou a evolução dos PIBs ( 1970 / 2014 - IPEADATA e SEADE) dos municípios paulistas localizados no vetor noroeste paulista, entre São Paulo e Campinas (Cajamar, Jundiaí, Louveira, Vinhedo, Valinhos, Campinas), e dos municípios que englobam o ABC Paulista (São Bernardo, Santo André, São Caetano, Diadema, Mauá, Ribeirão Pires e Rio Grande da Serra), região de forte dinamismo econômico do Estado, atrás até recentemente, apenas da própria capital.

A evolução deste processo, desde a década de 1970 até 2014, pode ser analisada através do Anexo I, encontrado no final da pesquisa. Os dados de 1970 até 1990 foram obtidos pelo Ipeadata. De 1999 até 2014 os dados tem como fonte a fundação SEADE.

A partir destes dados, o gráfico abaixo demonstra que é no inicio do século XXI que a economia ou, a soma dos valores de Pib dos municípios do vetor noroeste, ultrapassam a soma dos valores de PIBs municipais do ABCD Paulista. Ou seja, o segundo PIB do estado, concentrado até então no ABCD Paulista desloca-se para o vetor noroeste.

Conforme o gráfico, apesar da transferência do segundo maior PIB do estado, concentrado no ABCD Paulista, para o Vetor Noroeste, observa-se durante a primeira década deste século uma grande ascensão econômica das duas regiões. Isso demonstra que não há decadência econômica no $A B C D$ e sim uma redistribuição de riqueza que se estende além da escala metropolitana reduzindo dessa forma, os desequilíbrios regionais. 


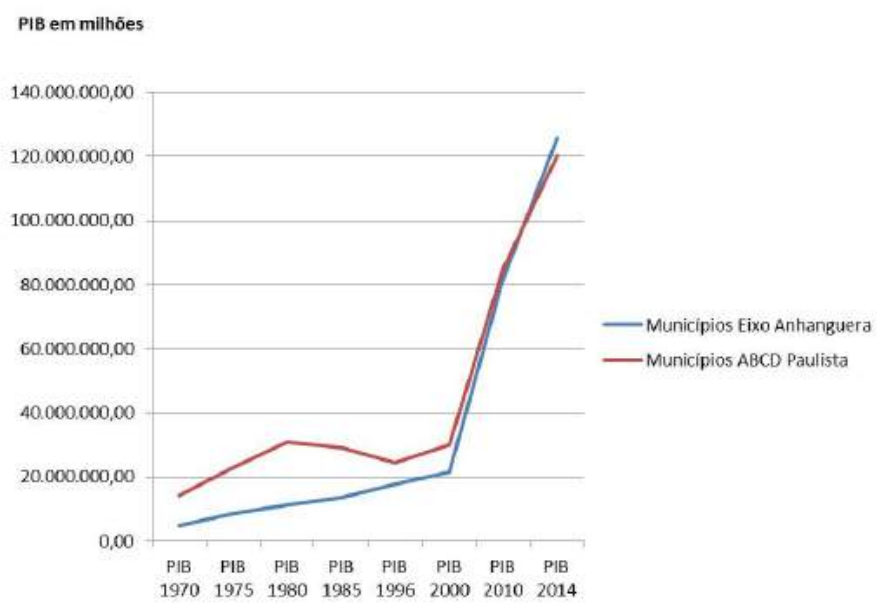

Gráfico 4.1: Evolução Pib 1970 - 2014 do Vetor Noroeste e do ABCD Paulista.

Fonte: Gráfico gerado a partir da planilha anexada elaborada com dados IPEADATA e SEADE.

Observa-se na imagem abaixo, a espacialização do PIB 2014, bem como, mudanças na concentração espacial das atividades econômicas no Estado a partir de 2014, bem como a ascensão de um novo eixo produtivo e regional de desenvolvimento, o vetor noroeste.

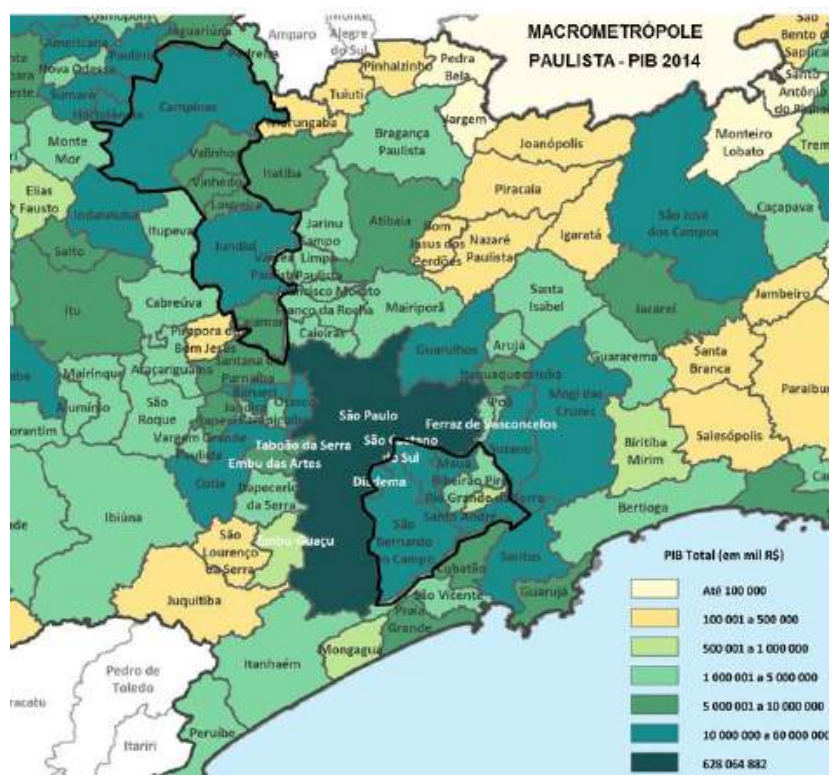

Figura 4.3: Espacialização PIB Municipal 2014: ABCD x Vetor Noroeste

Fonte: Elaborado a partir mapa Emplasa - Disponível em http://www.emplasa.com.br.

\begin{tabular}{|c|c|c|c|c|c|c|}
\hline $\begin{array}{l}\text { VETOR NOROESTE: } \\
\text { Cajamar, Jundial, Louveira, Vinhedo, Valinhos, Campinas }\end{array}$ & $\begin{array}{c}\text { PIB } 1996 \\
\text { milhơes reas } \\
\mathbf{1 7 . 6 6 1 , 2 9}\end{array}$ & $\begin{array}{c}\text { PIB } 2002 \\
\text { mihöos reas } \\
27.688,63\end{array}$ & $\begin{array}{l}\text { PIB } 2006 \\
\text { milhôes raais } \\
\mathbf{4 7 . 7 3 3 , 0 6}\end{array}$ & $\begin{array}{l}\text { PIB } 2011 \\
\text { milhoes teals } \\
93.967,03\end{array}$ & $\begin{array}{l}=\text { PIB } 2014 \\
\text { milhóes reais } \\
125.813,38\end{array}$ & $\begin{array}{l}\text { *PIB } 2015 \\
\text { milhöes reais } \\
132.476,15\end{array}$ \\
\hline $\begin{array}{l}\text { ABCD: } \\
\text { S.Bernardo, Sto.André, S.Caetano, Diadema, Mauá, Rib.Pires. }\end{array}$ & $\begin{array}{c}\text { PIB } 1996 \\
\text { malheses reais } \\
24.351,26\end{array}$ & $\begin{array}{l}\text { P1B } 2002 \\
\text { mihbós realis } \\
39.246,09\end{array}$ & $\begin{array}{l}\text { PIB } 2006 \\
\text { mulhos } \\
64.131 .67\end{array}$ & $\begin{array}{c}\text { PIB } 2011 \\
\text { milthés seals } \\
105.438,36\end{array}$ & $\begin{array}{l}\text { ×PIB } 2014 \\
\text { milhós reals } \\
120.190,95\end{array}$ & $\begin{array}{l}\text { *PIB } 2015 \\
\text { milhóes reais } \\
111.919,57\end{array}$ \\
\hline São Paulo: & $\begin{array}{c}\text { PIB } 1996 \\
\text { mulhoes reais } \\
140.386,85\end{array}$ & $\begin{array}{c}\text { P1B } 2002 \\
\text { mithés reais } \\
188.706,12\end{array}$ & $\begin{array}{c}\text { PIB } 2006 \\
\text { mulhoss sais } \\
283.840,19\end{array}$ & $\begin{array}{l}\text { PIB } 2011 \\
\text { milloes reals } \\
501.964,42\end{array}$ & $\begin{array}{l}\text { PPIB } 2014 \\
\text { milhoes rears } \\
628.064,88\end{array}$ & $\begin{array}{l}\text { *P1B } 2015 \\
\text { miltóses reatis } \\
650.544,78\end{array}$ \\
\hline
\end{tabular}

Tabela 4.1: Evolução de PIB - ABCD x Vetor Noroeste

Fonte: Elaborada a partir de dados SEADE. Disponível em http://www.seade.gov.br. 
Contudo, é importante ressaltar que as atividades inovadoras, financeiras e de poder continuam nos dois estágios de acumulação descritos, localizadas na cidade concentrada, ou seja, na capital paulista que detém de longe o maior PIB do estado.

Conforme dados do SEADE 2015, a capital continua com o maior PIB do estado (650 milhões de reais) concentrado no setor terciário. Todavia, a região do $A B C D$ apresentou em 2015 um PIB de 111 milhões de reais, enquanto o vetor noroeste da Capital apresentou um PIB de 132 milhões de reais, o que demonstra um progresso no que se refere ao equilíbrio regional do estado.

Cabe ressaltar que estamos falando de uma região metropolitana, de alta densidade construtiva e populacional, berço da grande indústria fordista instalada em território brasileiro, em sua maioria, antes da década de 1980, e hoje, transformada em centros comerciais e residenciais. Sua rede de rodovias se encontra saturada com grandes congestionamentos principalmente nos trechos próximos à capital. Devido a intensa ocupação e à existência da serra do mar, cada vez mais desaparecem extensões de terra disponíveis para abrigar grandes parques industriais.

Ou seja, deseconomias de aglomeração acabam por impulsionar outras regiões. Algumas indústrias deixaram o $A B C$ não devido a um contexto de crise, mas por que queriam se expandir, como é o caso da Volkswagen Parts \& Accessories Center, que deixou seu antigo centro de distribuição da Volkswagen em São Bernardo do Campo para instalar-se em 2004, em Vinhedo, em uma área maior, na margem da rodovia Anhanguera.

Observa-se na tabela abaixo, dados socioeconômicos das duas regiões entre 2010 - 2018.

\begin{tabular}{|c|c|c|c|c|c|}
\hline municipios & $\begin{array}{c}\text { População } \\
2018\end{array}$ & $\begin{array}{l}\text { T. Cresc anual } \\
2010 / 18 \% \text { aa }\end{array}$ & $\begin{array}{c}\text { PIB } 2015 \\
\text { mil reais correntes }\end{array}$ & $\begin{array}{c}\text { P1B } 2015 \\
\text { per capita reais }\end{array}$ & $\begin{array}{l}\text { Partic. no PlB do } \\
\text { Estado (Em \%) }\end{array}$ \\
\hline \multicolumn{6}{|c|}{ MUNICIPIOS EIXO ANHANG UERA -VETOR NOROE STE } \\
\hline CAMPINAS & 1.158 .944 & 0,9 & $56.400 .145,94$ & 49.711 .64 & 2,91 \\
\hline VALINHOS & 121.809 & 1,68 & $5.242 .015,46$ & $44.597,72$ & 0,27 \\
\hline VNHEDO & 74.858 & 2,09 & $7.635 .817,73$ & $107.493,74$ & 0,39 \\
\hline LOUVE RAA & 45.236 & 2,92 & $11.895 .643,24$ & $274.586,66$ & 0.61 \\
\hline JUNDIAI & 400.549 & 1,01 & 39.717 .585 .60 & 101569,11 & 2.05 \\
\hline CAJAMAR & 73.588 & 2,02 & $11.584 .945,53$ & $163.138,38$ & 0,60 \\
\hline TOTAL & 1.874 .984 & & $132.476 .153,50$ & & 6,83 \\
\hline \multicolumn{6}{|c|}{ MUNICIPIOS ABCD PAULISTA } \\
\hline SÃO BE RIIARDO & 803.771 & 0,62 & $42.745 .533,28$ & $54.008,53$ & 2,20 \\
\hline SANTO ANDRÉ & 690.551 & 0,26 & $26.240 .884,88$ & $38.274,00$ & 1,35 \\
\hline SÄO CAETAMO & 150.988 & 0,15 & $13.302 .120,23$ & $88.324,56$ & 0,69 \\
\hline DIADEMA & 401.159 & 0.49 & 13.854 .570 .11 & 34.965 .63 & 0.71 \\
\hline MAUÁ & 447.911 & 1.04 & 12.429 .673 .25 & $28.252,66$ & 0,64 \\
\hline RIB.PIRE S & 117.917 & 0,53 & $2.813 .435,16$ & $24 \cdot 179,13$ & 0,15 \\
\hline R.GRDE D/SERRA & 48.648 & 1,29 & $533.358,58$ & $11.358,15$ & 0.03 \\
\hline TOTAL & 2.660 .945 & & $111.919 .575,49$ & & 5,77 \\
\hline \multicolumn{6}{|c|}{ MUNICIPIO DE SÃO PAULO } \\
\hline SÃO PAULO & 11.753 .659 & 0,55 & $650.544 .788,73$ & $56.169,59$ & 33,60 \\
\hline
\end{tabular}

Tabela 4.2: Dados sócio econômicos dos municípios do eixo Anhanguera, do ABC Paulista, e da Capital. Fonte: Elaborada a partir de dados SEADE. Disponível em http://www.seade.gov.br. 
Nota-se crescimento da população inferior a um, em São Paulo (0.55\%), Campinas $(0.9 \%)$ e em quase todo $A B C D$, exceto Mauá e Rio Grd. da Serra. No vetor noroeste, Jundiaí apresenta as menores taxas crescentes $1,01 \%$. Os municípios de pequeno porte e menos industrializados como Louveira (2,92\%), Vinhedo (2,09\%) e Cajamar (2,02\%), apresentam as maiores taxas de crescimento da população, com aumento de seus fluxos migratórios, o que pressupõem o seu futuro desenvolvimento, em oposição ao das grandes áreas urbanas já consolidadas.

Além disso, altas taxas de crescimento coincidem com os maiores valores de PIB per capita de alguns municípios de pequeno porte inseridos no eixo Anhanguera. Reduzida população e a atração de fortes unidades da indústria moderna que ocupam grandes extensões, justificam o alto PIB per capita dos municípios de Louveira (1ํ PIB per capita

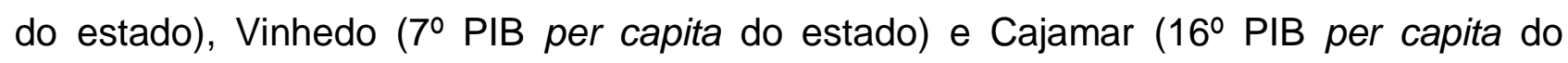
estado), e demonstram o potencial desenvolvimento desse eixo econômico do Estado..

Apresentado no final da tese, o ANEXO II demonstra como se movimentou nos seus diversos setores (primário, secundário, terciário) a economia dos municípios do Vetor Noroeste e do ABCD Paulista.

Analisando a evolução dos dados econômicos do ANEXO II, de 1999 até 2014, observamos uma continuidade do processo de desconcentração da atividade industrial da capital e da região metropolitana.

Porém, ressalta-se que o estado de São Paulo, vem perdendo sua participação relativa na indústria com relação à maioria dos estados brasileiros, o que significa que o crescimento industrial relativo do vetor noroeste (aumento de sua participação no total nacional), não compensa o decrescimento relativo da indústria da capital e da região metropolitana. Vale acrescentar que houve dispersão da indústria também do interior de São Paulo para outros estados, embora de forma menos intensa que a capital e a região do ABCD.

Isso significa que, as atividades industriais, além de estarem terceirizando seus serviços, não estão migrando apenas em direção ao interior, ou a uma única região concorrente do estado como o Vetor Noroeste, mas também para outros estados, ou seja, novos polos industriais fora do estado de São Paulo estão se consolidando. Porém, conforme já dito, apesar do movimento da indústria, hoje, nenhum outro parque industrial no país consegue concorrer de perto com a indústria paulista.

Com relação ao setor de serviços, os valores demonstrados no Anexo II, no final da pesquisa, evidenciam também a sua maior concentração na capital e no vetor noroeste, principal eixo estruturador de atividades terciárias do estado. Fato claramente relacionado 
com a migração, expansão e modernização da indústria neste vetor. A análise da evolução dos dados entre 2010 e 2015, mostra que diferentemente do setor industrial, o setor de serviços apresenta uma curva ascendente significativa de crescimento no Vetor Noroeste.

Observamos o mesmo processo ocorrendo na região do ABCD Paulista, ou seja, aumento no setor de serviços e redução do setor industrial, porém este último ocorrendo de forma bem mais significativa que no interior do estado.

Armazenamento e atividades auxiliares dos transportes é o setor que obteve o segundo maior crescimento e geração de emprego no período de 2006 até 2012, no Vetor Noroeste, sendo o comércio varejista o primeiro, conforme CNAE 2.0. Estas atividades de distribuição e logística, relacionam-se com o produto, mercadoria e portanto, estão diretamente relacionados com o setor de serviços que advém da fragmentação da indústria moderna.

Cidades como Cajamar, Jundiaí, Louveira e Vinhedo foram as que obtiveram maior destaque na geração de emprego nesse setor, que vem ocupando grandes glebas e acarretando nítidas transformações no uso do solo, principalmente nas áreas adjacentes as rodovias.

Apesar de São Paulo continuar liderando como principal polo econômico, essas transformações econômicas têm reduzido os desequilíbrios regionais, trazendo impactos territoriais de importância nacional.

Conforme dito anteriormente, a expansão na configuração metropolitana, com aumento de importância das cidades pequenas e médias e de novos pólos de desenvolvimento, requer um novo entendimento macrometropolitano e regional, que atente para a configuração de novos Territórios Metropolitanos.

Municípios adjacentes aos corredores produtivos regionais, como o sistema AnhangueraBandeirantes, cada vez mais se transformam em centros polarizadores de atividades e deslocamentos, demandando políticas públicas específicas para seu ordenamento e para a estruturação democrática desses territórios.

A análise destas experiências justifica a necessidade de uma reflexão voltada não apenas para o contexto municipal ou metropolitano, mas para a regionalização de áreas que se inserem em um mesmo contexto urbano e econômico, a fim de transformar os novos territórios estendidos ou metropolitanos em um projeto global de reorganização e 
requalificação do espaço urbano, ao invés do resultado espontâneo de um processo de ocupação sem planejamento, que pode gerar entraves futuros.

"A dinâmica metropolitana não é mais exclusiva da metrópole ou da região metropolitana institucionalizada. Essa realidade impõem um novo modo de pensar e de regionalizar o espaço " ( LENCIONI, 2004, p.154).

Cabe lembrar que além do território macrometropolitano, outras dimensões espaciais, ainda mais complexas, que extrapolam o Estado de São Paulo, merecem ser citadas. Gottman (1961), foi pioneiro ao falar em megalópole, uma região urbana na costa leste dos Estados Unidos, que se desenvolvia a partir da fusão de duas metrópoles, processo este considerado pelo autor como resultante de um estágio superior de desenvolvimento metropolitano.

No Brasil, o termo megalópole se refere à junção da região metropolitana de São Paulo com a Região Metropolitana do Rio de Janeiro. Distantes entre si aproximadamente 450 $\mathrm{km}$, essa mega-região é considerada o maior e mais relevante continuum urbano da América Latina, interrompida apenas pela Serra do Mar e apresentando complexas relações espaciais que foram descritas por Bentes (2014).

Essa megalópole brasileira também se estrutura por um sistema de rodovias implantadas respectivamente nas décadas de 1950 e 1980, constituída pelas rodovias Presidente Dutra e rodovia Ayrton Senna/Carvalho Pinto, no trecho Paulista.

Conforme a administradora Ecovias, a rodovia Ayrton Senna, antiga rodovia dos Trabalhadores, foi estendida na década de 1990, de Guararema até Taubaté, e denominada neste trecho de rodovia Carvalho Pinto. O corredor Ayrton Senna/Carvalho Pinto tem atualmente 134,9 quilômetros de extensão, com importante função econômica e faz parte do Corredor de Exportação Campinas - Vale do Paraíba Litoral Norte.

Nota-se que no século XX o eixo São Paulo - Rio de Janeiro era o promissor vetor de expansão da metrópole Paulista. Porém devido à sua ocupação industrial consolidada no âmbito da política de substituição de importações, nas décadas de 1950 e 1960, junto ao ABCD Paulista, bem como, o explosivo crescimento dos bairros periféricos, que margeiam a rodovia Dutra na região metropolitana de São Paulo, áreas livres de grandes dimensões se tornaram indisponíveis.

Esse processo contribuiu para tornar o vetor noroeste mais atrativo às indústrias, que reestruturaram seus processos produtivos a partir da década de 1990. 
Outro arranjo produtivo foi abordado por Queiroga e Benfatti (2007), e se refere ao processo de formação de uma nova entidade urbana no país: a Megalópole do Sudeste do Brasil que também se estende além da macretrópole paulista, e tem como origem a dispersão da indústria da Região Metropolitana de São Paulo.

Esse território se estende da metrópole de Campinas, importante polo regional, através de vetores de estruturação e expansão, para importantes municípios do Sul de Minas Gerais e, muito fortemente, do Rio de Janeiro.

Neste quadro ampliado dos espaços de produção e consumo, vai se verificando a continuidade do processo de expansão territorial da megalópole ao longo dos principais eixos rodoviários que irradiam, principalmente, da capital paulista, mas não só dela, estruturando uma configuração territorial mais complexa (QUEIROGA, BENFATTI,2007,p.45)

Outro arranjo produtivo, menor, inserido na macrometrópole paulista também merece atenção. Trata-se de dois eixos secundários produtivos que partem da metrópole de Campinas rumo a Sorocaba e São José dos Campos, e que conformam um triângulo econômico metropolitano, estruturado pelo vetor noroeste, e com promissoras relações econômicas.

Embora esta pesquisa não tenha abrangido, cabe ressaltar a forte interação que a metrópole de Campinas estabelece com todo interior paulista, principalmente com a aglomeração urbana de Piracicaba, ou seja, o dinamismo do vetor noroeste paulista se estende além da metrópole de Campinas, embora seu principal trecho seja o eixo SPCampinas, aqui abordado.

Essas abordagens colaboram para o entendimento de que a cidade, como entendida hoje, será diluída e anexada, configurando dimensões urbanas mais complexas, ou novos arranjos produtivos estruturados por corredores de riqueza, que tendem a constituir novos Territórios Metropolitanos.

Ou seja, esse processo de desterritorialização ou a crise da territorialidade, tem revelado novas escalas ou relações espaciais estendidas como, o Triângulo Metropolitano, ou a Macrometrópole Paulista, ou a Megalópole Rio-São-Paulo, ou ainda, a Megalópole do Sudeste do Brasil. Vale notar que o vetor noroeste paulista relaciona-se simultaneamente com essas quatro dimensões.

Esses novas escalas espaciais são estruturadas por corredores de riqueza que tendem a gerar conturbação e complementariedade socioespacial de municípios de pequeno e médio porte que por sua vez tendem a constituir outros novos Territórios Metropolitanos. 
Diferentes fluxos conectam o vetor noroeste paulista a outras dimensões espaciais, sem que ocorra, muitas vezes, integração e continuidade territorial. Espacialmente novas dimensões se integram, territorialmente, dinâmicas dispersas fragmentadas, ainda produzem vazios intersticiais.

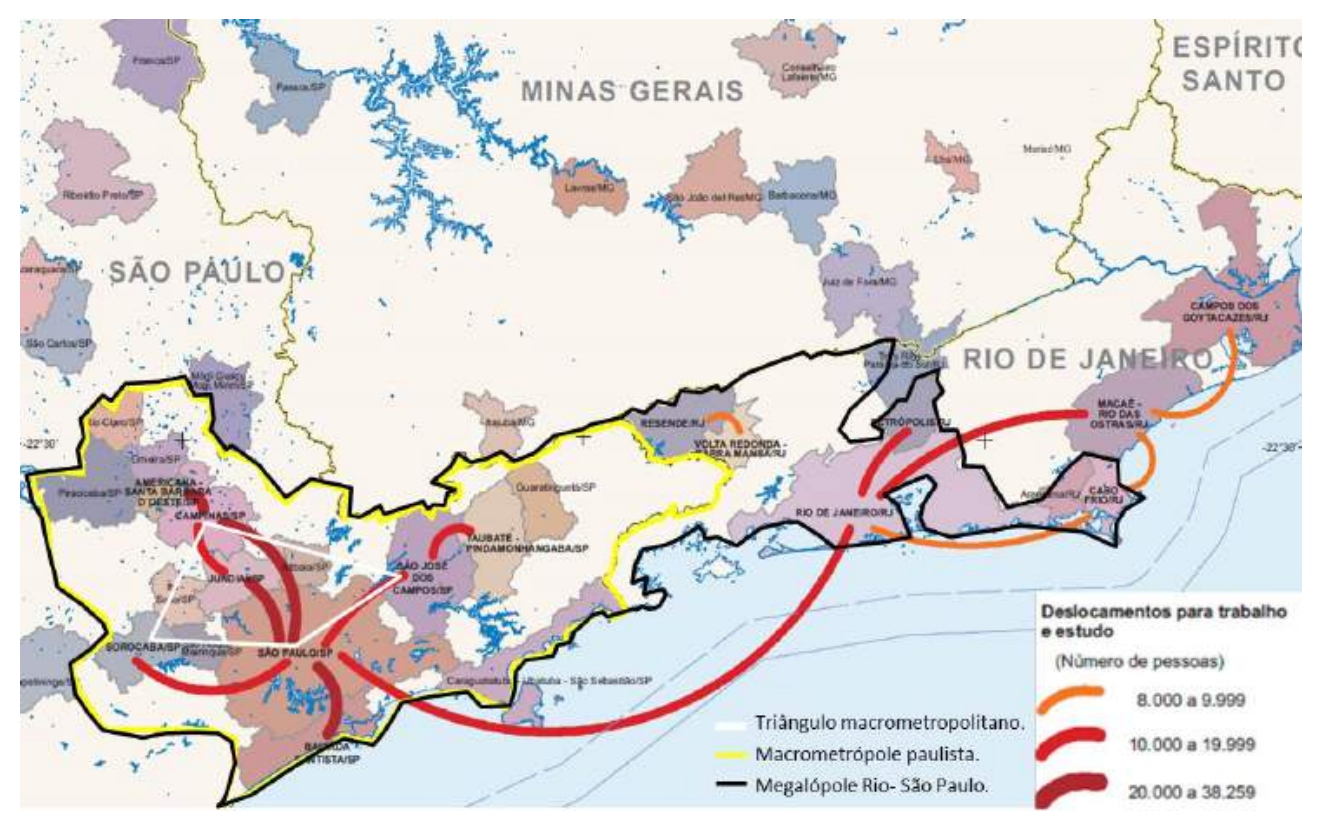

Figura 4.4: Intensidade dos deslocamentos pendulares entre SP. e Rio, e novas dimensões espaciais. Fonte: Elaborado a partir de base IBGE (2016).

Contudo é a integração desses vazios que constituirá novos territórios metropolitanos, portanto devem ser identificados e providos de um novo olhar devido a sua importância estrutural e à complexidade de suas relações territoriais e espaciais.

Ou seja, municípios que se integram espacialmente e territorialmente através de fluxos de deslocamentos e de continuidade territorial, constituem novas totalidades ou novos territórios metropolitanos que se estendem além de limites administrativos estabelecidos, e que devem ser objetos de um planejamento regional em escala ampliada.

Além disso, Lencioni (2004), ressalta que algumas atividades, até então exclusivas da metrópole, precisam ser replicadas para novas centralidades, para que a reprodução do capital continue sua expansão.

Ou seja, o modo de produção capitalista se baseia na frequente busca do lucro através da abertura de novos mercados e produz constante extensão e alteração na morfologia e nas dimensões territoriais, além de grande complexidade espacial. Esse processo é estruturado por corredores de riqueza que fragmentam o território nacional.

Devido à importância da metrópole de Campinas e de seus eixos de expansão na consolidação de novas dimensões espaciais, além do SAB, outros importantes vetores de expansão e riqueza, começam a se tornar expressivos e serão a seguir abordados. 


\subsection{Eixos Viários Produtivos de Integração e Fragmentação Espacial.}

Conforme Holland (1976), o crescimento do capitalismo estimula o desenvolvimento desigual das regiões e qualquer ação nesse sentido deve se basear na estrutura de competição capitalista, onde dois itens são fundamentais: o avanço do poder econômico das grandes corporações (capital monopolista), e o alastramento das operações multinacionais dessas corporações ( internacionalização plena do capital produtivo).

Segundo o mesmo autor, a criação de monopólios, ou as economias de escala com forte poder de mercado, transformam-se em barreiras à entrada de novos competidores no mercado. A base da problemática regional é a distribuição locacional. Enquanto empresas menores tendem a se localizar em arranjos menos desenvolvidos, grandes empresas se localizam em arranjos mais desenvolvidos, atraindo uma série de atividades de apoio em seu entorno, e principalmente de investimentos.

Regiões mais prósperas recebem mais investimentos, o que maximiza tanto as economias de escala como a difusão do progresso técnico. Dessa forma, ampliam-se as diferenças regionais e o padrão do crescimento regional.

A concorrência desigual, ou o poder de mercado de grandes empresas para máxima utilização dos fatores produtivos para redução de custos (obtenção de condições favoráveis de financiamentos, localização, distribuição, utilização do progresso técnico, das inovações, controle de consumidores e fornecedores, poder de barganha com municípios, governos estaduais e nacionais), gera desequilíbrio regional e a fragmentação do território nacional.

Do ponto de vista espacial, políticas públicas mais integradoras para atender deficiências existentes em termos de política habitacional, de transportes, saúde, educação, devem ser objeto de reflexão a fim de se evitar a fragmentação do território nacional, constituído de corredores de riqueza e zonas de pobreza.

Atualmente o sistema Anhanguera/Bandeirantes é considerado um dos principais eixos de desenvolvimento econômico do país, conectando a capital federal à maior metrópole brasileira, São Paulo. Pelo trecho entre São Paulo-Campinas, circula uma significativa parcela do produção nacional (PIB 728 bilhões de reais), que integra e configura um próspero território metropolitano formado por municípios com economia em ascensão e que se fortalecem mutuamente. 
Nas últimas décadas outros importantes corredores de riqueza industriais foram constituídos no país. Estimulado pela exploração de petróleo formou-se o corredor Rio de Janeiro a Campo de Goytacazes (PIB 339 bilhões de reais). No sul, destaca-se o tradicional eixo industrial catarinense, de Joinville a Florianópolis (PIB 83 bilhões de reais), e o trecho gaúcho de Porto Alegre a Caxias do Sul (PIB 113 bilhões de reais).

Além destes, conforme consultoria realizada ( EXAME/URBAN SYTEM) novos corredores de riqueza estão emergindo no país, sendo que dez se destacam e geram juntos $37 \%$ do produto interno bruto. Dentre os principais estão, Goiânia-Anápolis-Brasília (PIB 268 bilhões de reais, indústria farmacêutica e automotiva); Ribeirão Preto-Uberlândia (PIB 64 bilhões de reais, setor de serviços que substituiu o agronegócio); Fortaleza-Mossoró (PIB 66 milhões de reais, petróleo, energia eólica e frutas); Maceió-Recife e Campina Grande (PIB 157 bilhões de reais, indústrias atraídas pelo Porto de Suape).

Novos territórios metropolitanos se constituem, estruturados por corredores de riqueza, ou seja, são estimulados em sua maioria pela presença de infraestrutura, que atrai a desconcentração da indústria e dos usos ligados à economia moderna, promovendo o crescimento de cidades médias que apresentam custos reduzidos de produção, e se desenvolvem sem um planejamento urbano estratégico adequado.

Conforme Vainer (2007), observa-se no território nacional a existência de vetores de desenvolvimento e, ao mesmo tempo, de fragmentação territorial. Infraestruturas implantadas com o objetivo de integração territorial, porém, que muitas vezes se transformam apenas em espaços mercantis adequados às novas escalas, demandas econômicas e fluxos dominantes, e precedem um planejamento territorial que garanta ordenamento territorial e desigualdades regionais.

Conforme Vainer (2007), desde a segunda metade do século passado, com ênfase para o seu último quartel, grandes projetos mínero-metalúrgicos, petroquímicos, energéticos e viários reconfiguram o território nacional. Segundo o mesmo autor, esses projetos emergem de decisões políticas e não de necessidades e acabam por produzir a fragmentação do território.

O empobrecimento do estado e as privatizações ocorridas, a partir da década de 1990, aceleram esse processo de reconfiguração do território nacional. A privatização de setores relacionados à infraestrutura (Eletrobrás, Companhia Vale do Rio Doce, Petrobrás, concessionárias viárias), ou os grandes projetos de investimentos (GPIs), por exemplo, as hidrelétricas, agora privatizadas, tornam-se os atuais agentes planejadores do território. 
[...] os grandes projetos continuam portadores de um grande potencial de organização e transformação dos espaços, um grande potencial para decompor e compor regiões. Por sua própria natureza, projetam sobre os espaços locais e regionais interesses quase sempre globais, o que faz deles eventos que são globais-locais [...] (VAINER, 2007, p. 11).

Além do SAB, novos corredores secundários de riqueza e integração regional, localizados no vetor noroeste, também vêm se transformando em eixos de atração de metropolização dispersa, possibilitando a intensificação das relações entre Campinas e outras regiões do Estado de forte dinamismo, como o Vale do Paraíba, através da rod. Dom Pedro (SP065/1972) e Sorocaba através da rod. Santos Dumont (SP-075/década de 80).

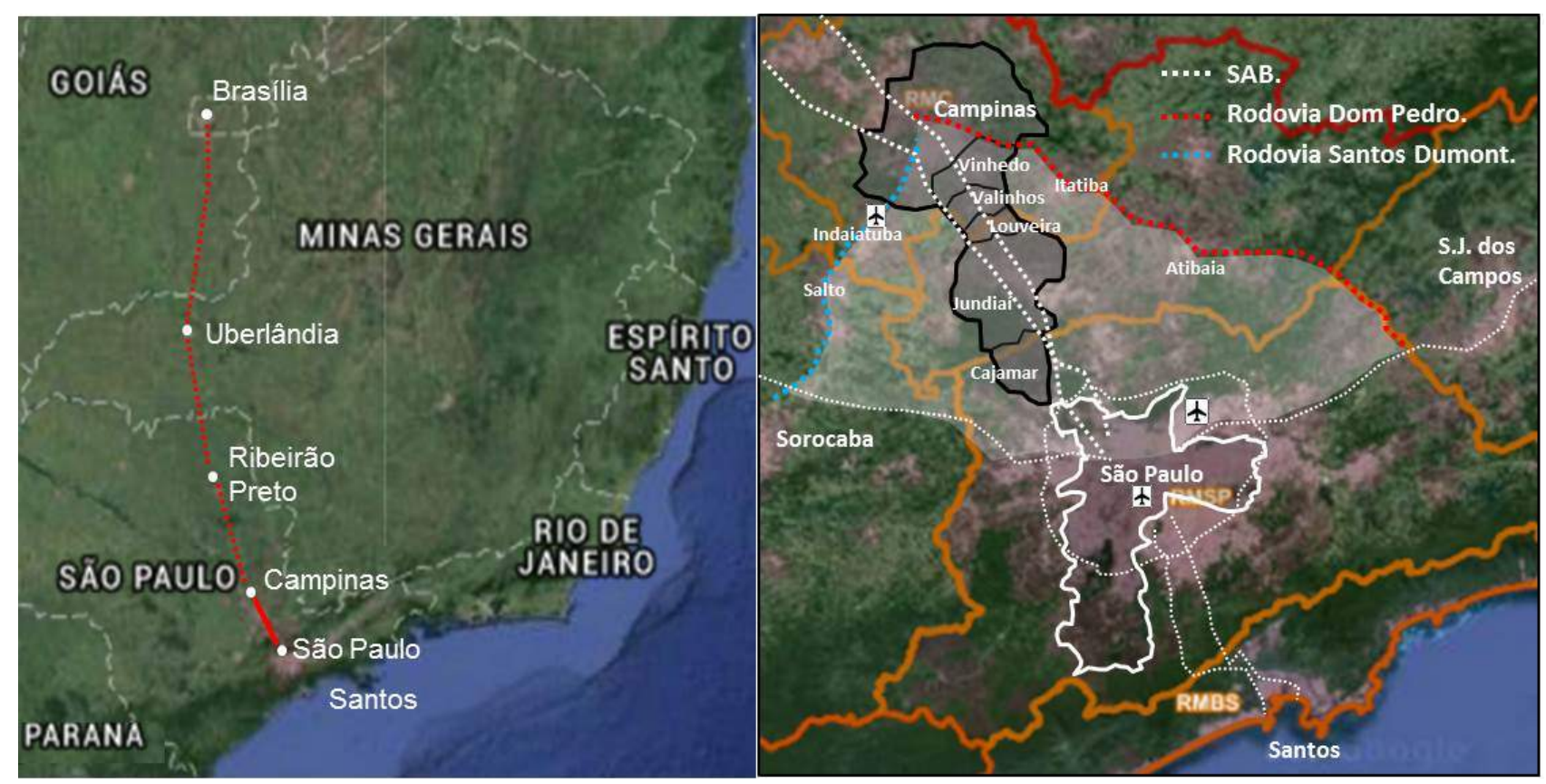

Figura 4.5: Rod. Anhanguera eixo de integração nacional e Eixos secundários do vetor noroeste.

Fonte: Elaborado a partir de base EMPLASAGEO. Disponível em http://www.emplasageo.sp.gov.br

Segundo Caiado e Pires (2007), nota-se, no período de 1989- 2000, pequenas manchas descontínuas na expansão da mancha urbana da RMC, principalmente na direção dos municípios de Indaiatuba e Itatiba, além de Valinhos, Vinhedo.
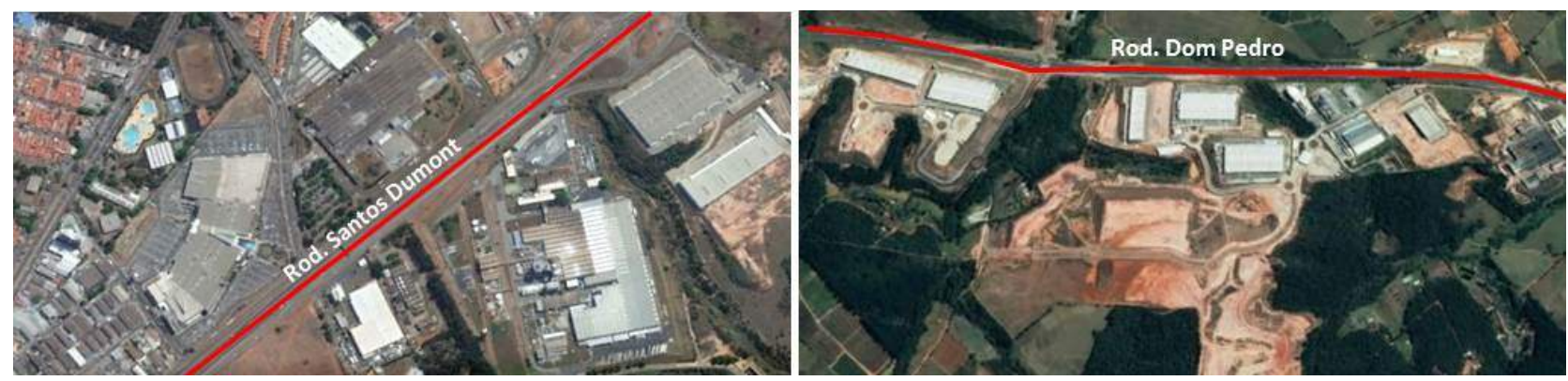

Figura 4.6: Cond. Industriais rod. D.Pedro-Atibaia e Shopping e indústrias na rod. Stos Dumont -Indaiatuba. Fonte: Elaborado a partir de imagem: //www.googleearth - acessado em 10012018 
Ou seja, embora cada uma possua suas especificidades, dinâmicas de dispersão urbana se manifestam também nos eixos da rodovias Santos Dumont e Dom Pedro, cuja conexão com o SAB não ocorre mais somente pela metrópole de Campinas, mas agora também através do fortalecimento de eixos transversais, como as estradas que ligam: Vinhedo/Viracopos-Indaiatuba; Louveira/Itatiba; Jundiaí/tu; Jundiaí/Campo Limpo.

Na rodovia Santos Dumont, as regiões de Campinas, Indaiatuba e Salto se encontram praticamente em um continuum urbano. Itu e Sorocaba mais adiante parecem seguir a mesma tendência.

Na rodovia Dom Pedro, no trecho entre Valinhos a Jacareí (Valinhos, Itatiba, Jarinú, Atibaia, Bom Jesus dos Perdões, Nazaré Paulista, Igaratá e Jacareí) os processos de conurbação ainda não são tão intensos, embora já se identifique mudança na paisagem rural de suas margens, recentemente substituídas por ocupações de grande porte e impacto territorial, relacionadas à economia moderna.

Cabe lembrar que Campinas, por sua posição estratégica no território, desenvolveu desde cedo função polarizadora na mais rica região agrícola do interior paulista, além de uma relação de mutualidade com a capital. Isso ocorreu no século XIX com o complexo econômico cafeeiro apoiado em sua rede ferroviária, como com a industrialização pesada, iniciada a partir da segunda metade do século $X X$, que tem como importante suporte espacial a rodovia Anhanguera (FONSECA, DAVANZO, NEGREIROS, 2002).

No século XXI, a localização estratégica da metrópole Campineira é cada vez mais fortalecida devido a sua conexão com outros importantes eixos produtivos regionais do estado de São Paulo.

A rodovia Santos Dumont (SP 075) é a principal ligação de Campinas ao Aeroporto Internacional de Viracopos. No final da década de 70 , antes da rodovia, implantou-se em seu eixo o primeiro Distrito Industrial de Campinas, na época com presença de grandes empresas nacionais e multinacionais. Sua duplicação foi concluída em 1991, pela Dersa. Atualmente está sofrendo intenso processo de ocupação diversificada, embora muitas dessas ocupações se relacionem com a proximidade e expansão do Aeroporto.

A rodovia Dom Pedro (SP 065), partindo da Anhanguera até Valinhos, faz parte do anel viário de Campinas, um eixo metropolitano de lazer e consumo, com shopping centers, hipermercados, lojas especializadas, condomínios e loteamentos residenciais, além deser principal eixo de conexão entre diferentes intituições de pesquisa como Unicamp, Puccamp, Cpqd e CTI (MITICA NETO, 2008). 
Seu trecho que se estende de Campinas até Jacareí, suporta todo fluxo de veículos entre o interior paulista e o litoral norte do estado, bem como, com o Rio de Janeiro e com Belo Horizonte, através das rodovias Dutra/Carvalho Pinto e Fernão Dias, respectivamente.

A rodovia Dom Pedro, devido a sua conexão entre a refinaria de Paulínia e o porto de São Sebastião, teve sua importância redobrada recentemente, com a descoberta do Pré-sal. A rodovia Santos Dumont enfrenta intenso processo de ocupação terciária, devido a sua conexão com o Aeroporto de Viracopos, em processo de expansão e aumento de sua projeção nacional.

Ao mesmo tempo, verifica-se, a partir da década de 1990, o aumento das ocupações precárias e informais, no entroncamento da Via Anhanguera com o Rodoanel, nas regiões próximas a São Paulo, no eixo Bandeirantes, e em menor escala na Rod. Santos Dumont.

Os três períodos de gestão do Sistema Anhanguera/Bandeirantes, inicialmente administrado por uma empresa estatal o DER; depois por uma empresa mista, a DERSA (1976), e depois terceirizada por uma empresa privada, a CCR Autoban (1998), coincidem com o processo de enfraquecimento do estado pós década de 1980 e com o fortalecimento do setor privado.

Esse processo transitório de gestão impactou fortemente não apenas o aumento da mobilidade do $S A B$, mas também, sua ocupação que passa a ser fragmentada e heterogênea, e constituída de grandes obras privadas como condomínios industriais Ao mesmo tempo, observa-se o aumento de suas ocupações informais.

Demandas econômicas associadas às políticas públicas de transporte, foram responsáveis pela criação em 1934 do DER (empresa estatal), em 1945 do Fundo Rodoviário Nacional, e em 1969 da DERSA (empresa mista), que possibilitaram um avanço no desenvolvimento rodoviário no estado, que foi acompanhado por um desenvolvimento econômico e urbano com ênfase para o eixo em estudo.

Com a extinção na década de 1980 do Fundo Rodoviário Nacional, sucedeu-se uma situação de crise do sistema rodoviário nacional e, no final da década de 1990 no contexto da Reestruturação Produtiva, dentro do Programa Estadual de Desestatização e parcerias com a iniciativa privada do Governo de São Paulo, a partir de 1998, o SAB passou a ser administrado pela concessionária privada CCR Autoban.

Com o objetivo de regular e fiscalizar o Programa de Concessões Rodoviário concebido em 1998, criou-se, em 2002, a Artesp - Agência Reguladora de Transporte do Estado de São Paulo, a fim de implementar uma política estadual de transportes. 
Não se pode negar que a CCR-Autoban, passou a conferir um novo padrão de desenvolvimento às rodovias. Porém, ao mesmo tempo em que se observam melhorias e investimentos viários no Sistema Anhanguera/ Bandeirantes, os custos para o usuário também se tornam cada vez mais elevados, restringindo seu uso e ocupação territorial às camadas e setores mais abastados.

O Grupo CCR é uma das maiores empresas brasileiras de concessão de infraestrutura, com atuação nos segmentos de concessão de rodovias, mobilidade urbana e serviços, com altíssimo valor de mercado. A companhia é responsável por 3.284 quilômetros da malha rodoviária nacional concedida nos Estados de São Paulo, Rio de Janeiro, Paraná e Mato Grosso do Sul.

No setor de serviços o grupo opera os meios eletrônicos de pagamento Sem Parar e Via Fácil. Além disso, tem diversificado sua atuação em mobilidade através das concessionárias ViaQuatro, CCR Barcas e CCR Metrô Bahia, responsáveis, respectivamente, pela operação da Linha 4-Amarela do metrô de São Paulo, pelo transporte aquaviário de passageiros no Rio de Janeiro e pelo sistema metroviário de Salvador e Lauro de Freitas. Também tem participação na concessão do Veículo Leve sobre Trilhos, VLT Carioca, que interligará a região portuária e o centro do Rio de Janeiro.

Desde 2012, o Grupo ingressou no setor aeroportuário, obtendo participação acionária nas concessionárias dos aeroportos internacionais de Quito (Equador), San José (Costa Rica), Curaçao e BH Airport (concessionária do grupo que administra o Aeroporto Internacional de Belo Horizonte, em Confins, Minas Gerais).

A CCR Autoban tem como objetivo viabilizar soluções de investimentos e serviços em infraestrutura de modo a oferecer segurança e conforto para motoristas, passageiros e pedestres com padrões que permitam melhores condições de fluidez de tráfego.

Desde 1998, já investiu cerca de $R \$ 5,3$ bilhões em obras de melhoria, ampliação, infraestrutura, modernização do sistema operacional, conservação, fiscalização e monitoramento das rodovias, destacando-se a construção do prolongamento da Rodovia dos Bandeirantes, primeira grande obra inserida no Programa de Concessões Rodoviárias do Estado de São Paulo.

A cobrança do pedágio é a principal fonte de recursos para sanar as despesas da concessionária em obras, conservação, prestação de serviço e tributos. Segundo, a CCR os reajustes previstos são anuais, seguem índices oficiais e são regulamentados pelo Estado, representado pela ARTESP - Agência de Transporte do Estado de São Paulo, conforme contrato de concessão. 
O contrato de concessão do sistema Anhanguera /Bandeirantes, completará vinte anos em 2018, com possibilidade de renovação. De difícil leitura, as informações sobre o controle pelo Estado nos preços praticados pela CCR para exploração desse Sistema de rodovias, não foram localizados.

Conforme descrito, observa-se um crescimento exponencial da concessionária ao longo dos quase vinte anos em que tem administrado infraestruturas de transporte, transformando-se em um dos maiores conglomerados do país.

Recentemente, várias obras foram realizadas pela CCR Autoban, como o término da quarta pista da Via Anhanguera, entre Campinas e Jundiaí (2013), a ampliação da quinta pista em alguns trechos da Rodovia Bandeirantes (2014), as obras do complexo viário de Jundiaí que em breve será entregue, dentre outras.

Vale ressaltar que além de induzir uma nova demanda, a provisão de eixos rodoviários induz novos usos do solo de menor densidade baseados na motorização que não viabilizam investimentos em transporte público de massa, acarretando imobilidade urbana, ou, o acesso restrito ao território apenas para a minoria motorizada.

No final da primeira década do novo século, apesar do contínuo processo de investimento e melhoria realizado pela concessionária Autoban no sistema de rodovias Anhanguera/Bandeirantes, observa-se o aumento dos seus congestionamentos.

$\mathrm{Na}$ rod. Bandeirantes - autoestrada fechada e principal eixo de mobilidade do estado com impacto nacional, problemas de congestionamento e ocupação urbana se manifestam em suas margens, repetindo o mesmo padrão observado na rodovia Anhanguera, tida como uma estrada fechada, há quase setenta anos atrás quando foi inaugurada.

Observa-se o constante investimento financeiro para a modernização de infraestruturas de mobilidade, como o sistema Anhanguera/Bandeirantes, a conclusão dos trechos do Rodoanel pela Dersa, cuja conclusão do último trecho, norte, está prevista para o fim deste ano, a expansão do Aeroporto de Viracopos e do Porto de Santos.

Aliado a essas grandes infraestruturas, a possibilidade de implantação do trem regional, que retomaria o modal ferroviário de grande importância para estruturação desse território, desativado ao longo do século XX e substituído pelo modal viário, objetivam garantir um suporte espacial adequado que permita a intensificação do desenvolvimento econômico do Estado. 


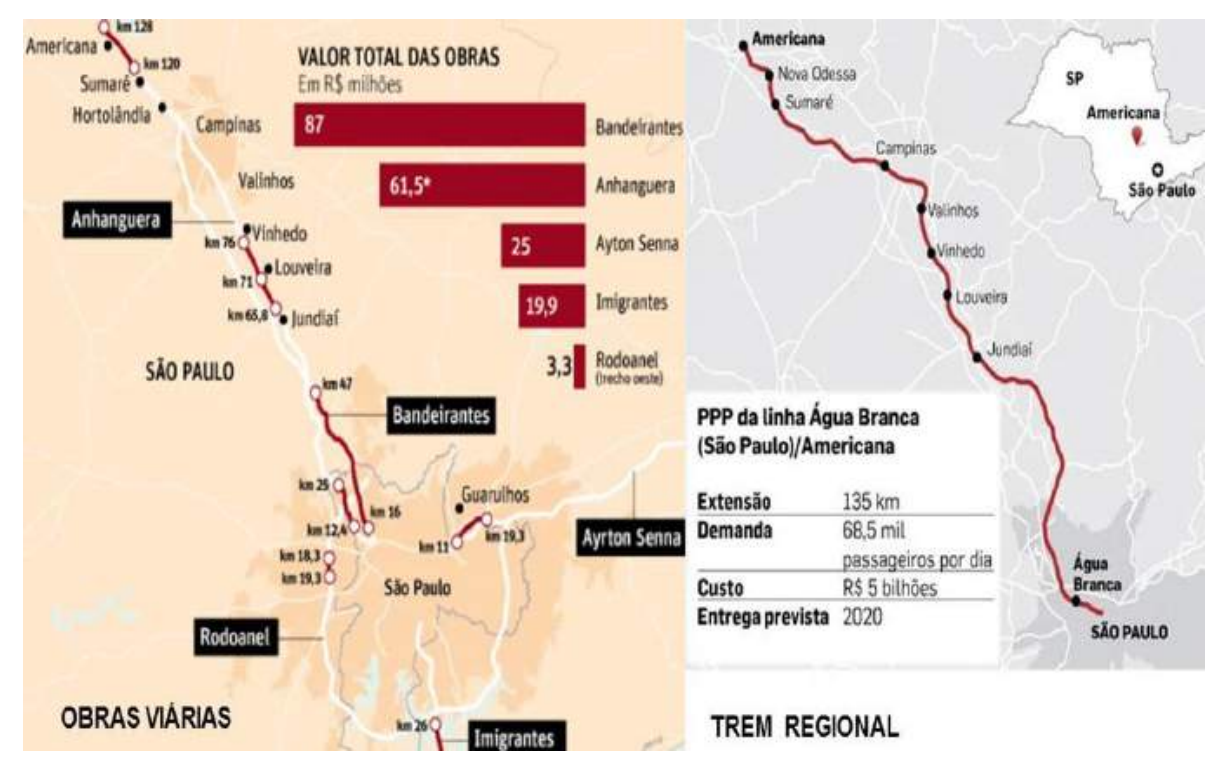

Figura 4.7: Valores de investimentos em obras viárias e trem regional.

Fonte: www1.folha.uol.com.br/cotidiano/1244674 - Infográfico/Estadão, 12 Setembro 2014.

Estes eixos se transformam em importantes corredores de mobilidade a nível nacional, e de exportação a nível global, gerando os maiores PIBs do Estado e do País, e ao mesmo tempo, permitem a constituição de formas urbanas estendidas e valorização imobiliária.

Conforme reportagem do Correio Popular, após muita discussão, o governo do Estado anunciou a licitação para agosto, da implantação do primeiro trecho do Trem Intercidades (TIC), entre Americana, Campinas e São Paulo, com $135 \mathrm{~km}$, custo estimado de $\mathrm{R} \$ 5$ bilhões, e possível compartilhamento das vias férreas, entre o transporte de cargas e o de passageiro. Caso se viabilize trará novos rumos para esse vetor e forte impacto regional.

Cabe ressaltar que a Via Anhanguera é parte integrante da rodovia federal, BR-050, uma das mais movimentadas do país, que começa em Brasília/DF e termina em Santos/SP, passando pelos Estados de Goiás, Minas Gerais e São Paulo. A BR-050 é um importante eixo viário interestadual, que promove a integração de Brasília com o Triângulo Mineiro, atendendo diretamente Araguari, Uberlândia, Uberaba, e viabilizando um corredor até São Paulo, por meio da SP-330 Anhanguera (Ribeirão Preto, Campinas, S.P.).

Observa-se que apesar da Anhanguera ser um eixo regional, é a legislação municipal junto a CCR, que regulam sua ocupação, pois, não existe no Brasil instrumentos de gestão metropolitana que articule municípios, o que torna difícil um planejamento urbano e integrado de áreas em um continuum urbano, pertencentes a diferentes municipalidades.

Os mapas de zoneamento e uso e ocupação do solo, obtidos nas prefeituras dos municípios de pequeno porte atravessados pela Via Anhanguera no trecho entre São Paulo e Campinas, permitem uma compreensão inicial da forma como o tecido urbano ao 
longo desse promissor corredor regional terciário, estruturador do desenvolvimento de cidades pequenas e médias, vem sendo planejado, ocupado e regulado.

Apesar das análises empíricas anteriores demonstrarem um eixo em processo de urbanização avançada, relacionado com as ocupações terciárias ligadas à economia moderna, com impactos territoriais significantes, tanto do ponto de vista local como regional, observa-se uma atuação municipal de regulação urbana tímida, frente a ocupações do setor privado, de forte impacto econômico e territorial.

Análise dos planos diretores e zoneamentos municipais demonstrou não haver legislação rígida e diferenciada para ocupação desses corredores urbanos, nem articulação de legislação de uso do solo com infraestrutura de transporte e tampouco políticas habitacionais de baixa renda, que garantam sua ocupação diversificada e democrática.

Embora a constituição de 1988 atribua à esfera municipal planejar e regular o uso do solo através de planos diretores municipais, as recentes dinâmicas que ocorrem em outra dimensão ou em escala regional, e são estruturadas por corredores de riqueza, requerem planos de regulação regionais que compreendam esses territórios dispersos sob outra ótica de atuação e que impeçam que os municípios se tornem suscetíveis às pressões econômicas impostas por agentes privados e pelo mercado.

Além disso, controle do lucro e contrapartidas urbanas que garantam não apenas boas condições de fluxo veicular, mas espaços coletivos de qualidade que integrem municípios e bairros segregados devem ser implantados e mantidos pelas empresas de concessão rodoviária, fiscalizadas por agências públicas reguladoras.

Dessa forma, produz-se um território nacional mais homogêneo e, amenizam-se os desequilíbrios regionais existentes entre o restante da nação e os corredores de riqueza, que estruturam novos territórios metropolitanos que por sua vez estruturam novas dimensões e arranjos espaciais.

O próximo capítulo propõe a partir de um modelo de matrizes, um plano regional, que define diretrizes para sanar as deficiências atuais e futuras desse novo território metropolitano, estruturado por corredores de riqueza principais (sistema Anhanguera/Bandeirantes), e secundários ( rod. Dom Pedro e rod. Stos Dumont). 


\section{Proposição: Plano Regional}

Devido à importância nacional que esse novo território metropolitano assume na contemporaneidade, e considerando as múltiplas dimensões em que se relaciona, bem como a ausência de políticas mais integradoras, propõem-se um plano de matriz para melhor entendimento e gestão deste território nas múltiplas escalas em que este se relaciona. 


\subsection{Metro Matrix System.}

Dados da ONU, demonstram que 54 \% da população mundial reside atualmente em áreas urbanas, e a previsão de seu aumento para 66 \% em 2050; conseguir planejar áreas urbanas torna-se um dos mais importantes desafios do século XXI.

No atual mundo urbano, o futuro a médio e longo prazo das grandes aglomerações urbanas e metropolitanas dependerá do modo como planejamos e gerenciamos hoje, seu processo de urbanização e crescimento. O rápido processo de transformação dos territórios metropolitanos contemporâneos requer formas inovadoras de gestão e controle.

Utilizando-se da abordagem de Viganò (2015) e Ortiz (2013), a pesquisa aprofunda-se na construção de uma Matriz, Metro Matrix-System (ORTIZ,2013), para atuação e controle de territórios metropolitanos nas múltiplas dimensões em que estes se apresentam.

Viganò (2015), discorre acerca da capacidade de produção de conhecimento sobre o território, através de três dimensões de análise: o território conceitual, o território da descrição, e o território do futuro.

O primeiro, reflete sobre a produção de conceitos e teorias, e também utiliza e reinterpreta conceitos provenientes de outros campos. O segundo, faz uma operação de descrição e questiona irregularidades, inflexões, diferenças, repetição e pressupostos. A descrição confere individualidade a cada lugar e pode produzir teorias da transformação do território. E o terceiro, elabora uma reflexão sobre o futuro, considerando as reflexões teóricas e descritivas que relacionam diferentes tempos.

Os estudos de Ortiz (2013), realizados para controlar de forma sustentável o explosivo crescimento de algumas metrópoles como México, Cairo, Cartagena, Bogotá e outras, propõe o aprofundamento teórico e prático de um método de análise e gestão territorial $\mathrm{CiTi} /$ Metro-Matrix System, que se baseia na articulação de um sistema de matrizes.

O método, Metro- Matrix System estrutura-se em três etapas: análise do território e seus principais desafios; síntese das soluções para os desafios encontrados e proposta e desenvolvimento de um plano de ação baseado na matriz construída.

A matriz estabelecida permite evidenciar de forma sistêmica as múltiplas relações que uma área ou município assume dentro do território nacional. Ou seja, extrapola-se a relevância da escala local, e considera-se a importância territorial dentro de um sistema mais amplo e complexo de relações econômicas e sociais, permitindo sua integração. 
Segundo o autor, o maior desafio do planejamento urbano atual para controlar esse processo de urbanização sem precedentes é a compatibilização de escalas.

Conforme Contin (2015), a matriz nos permite encontrar "áreas de intercâmbio ", ou seja, comuns às diferentes escalas, e onde novos desenvolvimentos urbanos garantam a evolução do modelo urbano local para um projeto mais amplo de crescimento, integração e transformação regional, este o maior desafio que o método matriz system busca atender.

Além disso, conforme a mesma autora, temos que tentar pensar em um tempo de execução viável para um desenvolvimento urbano compatível tanto a curto como a longo prazo, sem ter que se esquecer de um deles, e com uma forte preocupação sobre o espaço físico-cultural, que é a única garantia real para um desenvolvimento participativo, ou seja, que não seja imposto aos cidadãos.

Conforme Viganò (2010), o projeto antes de ser definido em todos os seus elementos, é conceitualizado e equipado com uma representação diagramática, esquemática, abstrata, metafórica, nem sempre mensurável ou de escala e que muitas vezes depende de relações de proximidade. Há uma idéia de que a representação da projeção antecede a realização do projeto, e contribui para estruturar e repensar conflitos territoriais.

O domínio teórico obtido nos capítulos anteriores assumirá, nesta pesquisa, a mesma estrutura descrita por Viganò (2015), ou seja, as investigações conceituais, evolutivas e descritivas que constam nos capítulos I,II,III,IV, serão aplicadas para formulação de um espaço propositivo e futurístico, e serão a base teórica imprescindível para a construção da metodologia CITI/Metro-Matrix.

Este sistema de matrizes objetiva garantir um planejamento urbano que contemple esse território em sua totalidade, ou seja, nas diversas dimensões em que ele se apresenta, e garanta seu controle e equilíbrio a longo prazo.

A construção e a aplicação desta matriz evidencia que os munícipios de pequeno porte localizados no vetor noroeste assumem uma importante relação dentro de um sistema muito mais amplo, que não se limita à dimensão municipal, mas se estende, abrangendo relações nas dimensões metropolitanas, macro metropolitana e nacional.

Conforme Ortiz (2013), as três etapas básicas, Análise, Síntese e Proposta, que estruturam a construção dessa matriz, são elaboradas a partir de um processo investigatório. No caso do vetor noroeste essas etapas foram abastecidas pelas proposições até o momento descritas pela pesquisa. 

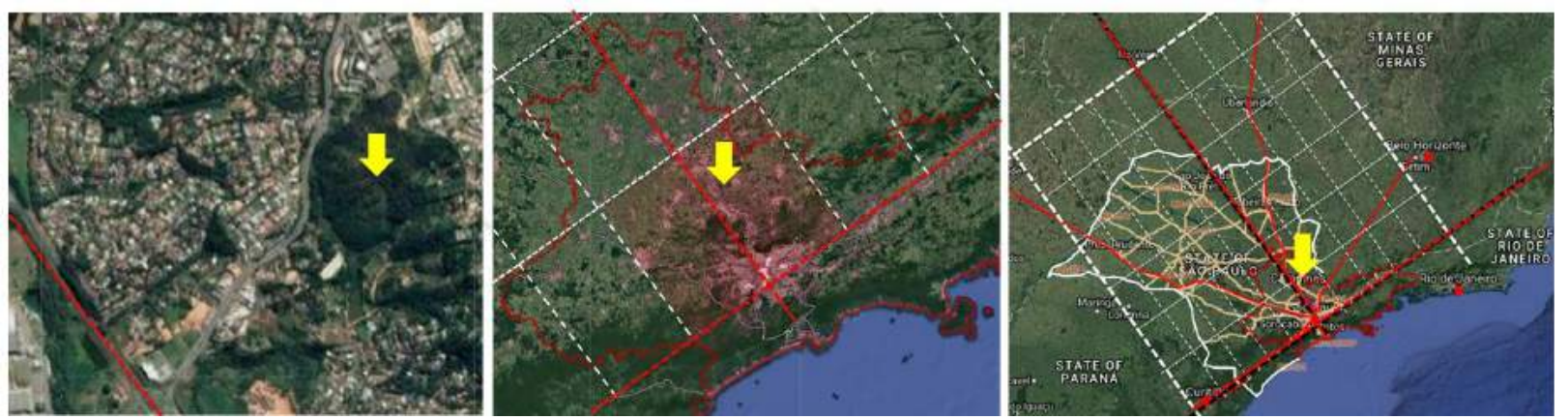

Figura 5.1: Múltiplas escalas - Vazio urbano Valinhos e sua relação macrometropolitana e nacional.

Fonte: Elaborado a partir de base Emplasa
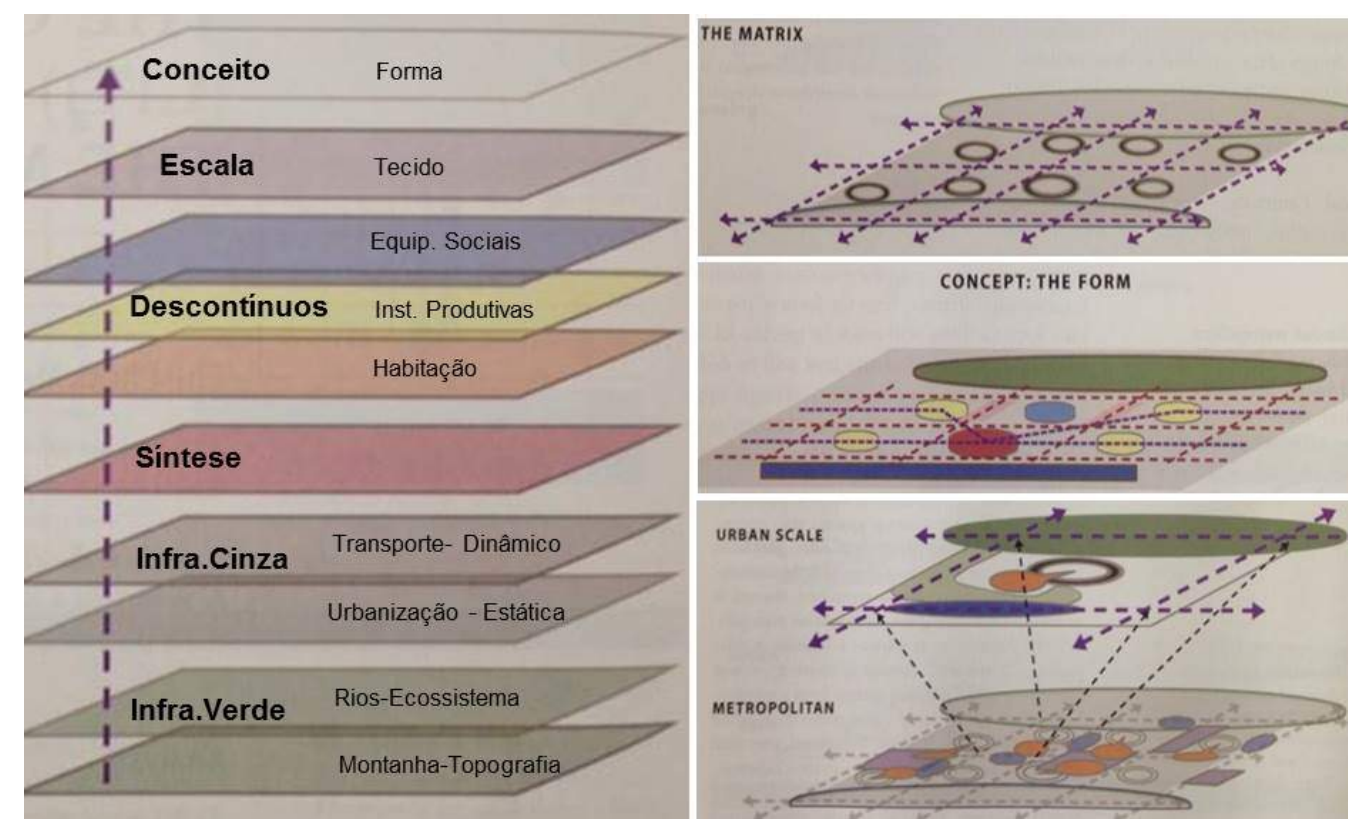

Figura 5.2: Articulação Matrix-System. Conclusão matriz. Definição forma. Compatibilização escalas. Fonte: The art of shaping the metropolis, pág 94, 97, 98 e 100

A primeira etapa de Análise foi estruturada na abordagem de cinco subsistemas básicos necessários para abordagem de áreas metropolitanas: Infraestrutura (gray infrastructure), Meio Ambiente (green infrastructure), Habitação (housing), Instalações Produtivas (productive facilities), Equipamentos Sociais (social facilities).

A Infraestrutura (gray infrastructure), engloba transporte e assentamentos urbanos. Ambos normalmente se ajustam da melhor forma às condições topográficas e geográficas apresentadas.

O entendimento das redes primárias e secundárias de rodovias ou ferrovias, existentes e desativadas, bem como, das características dos assentamentos urbanos ou dos espaços edificados existentes (compacto ou disperso, linear ou radiocêntrico) são fundamentais para se estabelecer a estrutura da malha urbana. 
O Meio Ambiente (green infrastructure), abrange elementos geográficos e topográficos (montanha, costa, rio, vale, floresta) que determinarão os principais limites de uma forma urbana, bem como seu futuro desenvolvimento.

Os dois primeiros itens acima descritos (Meio Ambiente e Transporte) são considerados subsistemas contínuos. O maior desafio normalmente encontrado nesta etapa, é sintetizar os subsistemas contínuos, a fim de que se tornem compatíveis, pois ambos abrangem áreas contínuas do território.

Após esta integração, ajusta-se os outros subsistemas, Habitação, Instalações Produtivas e Equipamentos Sociais, que são distribuídos de forma descontínua no território. Dessa forma, define-se a escala do tecido urbano, sobre o qual se definirá uma forma urbana.

$\mathrm{Na}$ segunda etapa, Síntese, após a integração entre meio ambiente, transporte e estruturas urbanas se originou uma matriz. Cada aglomeração urbana ou metropolitana deve coordenar os cinco subsistemas.

A partir do levantamento anterior definiu-se uma matriz estruturada por eixos topográficos, geográficos e de infraestrutura. Além disso, por centralidades que se manifestaram, pela distância entre elas, como também, pela formação de áreas intersticiais.

Além disso, deve-se prever nesta etapa uma estrutura para expansão da forma configurada. A análise Metro-Matrix definirá uma forma específica para cada região, bem como uma tendência natural para sua expansão e controle.

$\mathrm{Na}$ terceira etapa, após definição da matriz, desenvolve-se uma proposta. É fundamental nesta etapa ilustrar e explicar a compatibilização da escala do planejamento metropolitano (1:50.000), integrada à escala do planejamento urbano ou do tecido urbano (1:5000). Alguns elementos (matrix units) devem ser resolvidos na escala metropolitana, pois exercem funções de alto nível estratégico: estações intermodais, relevantes centralidades, centros produtivos e equipamentos sociais (hospitais, estádios, e universidades).

Nas centralidades urbanas, deve-se prever uma expansão habitacional para os próximos trinta anos e também a expansão de infraestrutura nas adjacências dessas centralidades. Nas centralidades regionais deve-se prever pontos de intersecção, para conectar os equipamentos estratégicos tanto com as centralidades urbanas, como também, com as infrestruturas de alta capacidade.

Além disso, deve-se prever áreas econômicas estratégicas (centros de pesquisa, zonas de exportação ou centros de negócios internacionais), bem como uma rede internacional 
de transporte (aeroportos ou portos) que dependerá do papel que esta região exercerá na rede de funções global.

A análise Metro-Matrix define uma forma específica para cada metrópole ou região e as tendências naturais para a evolução desta forma. Ou seja, torna-se fundamental neste processo a definição da essência ou identidade de uma região, bem como a sua projeção para o futuro, através da proposta de um plano regional.
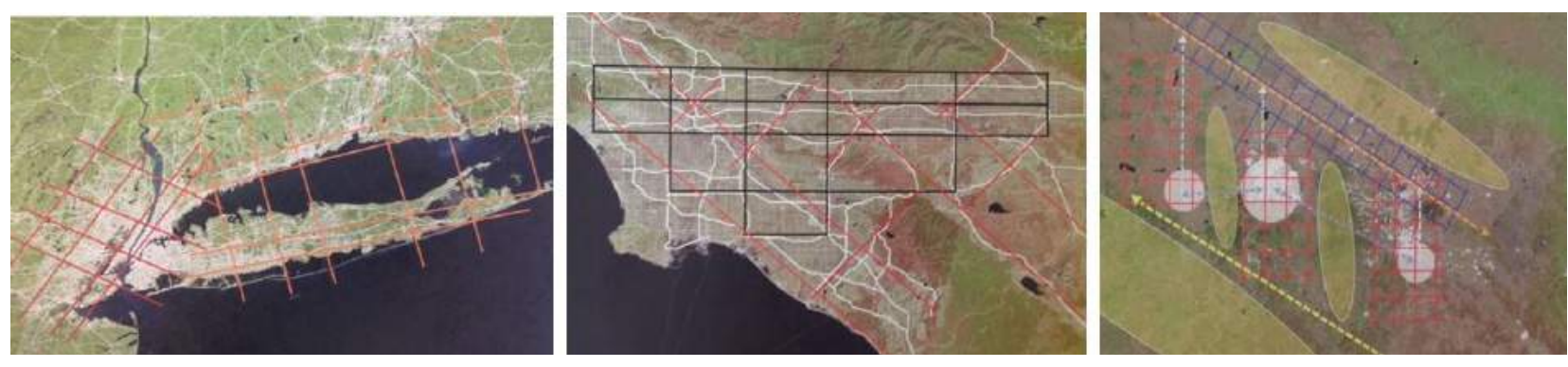

Figura 5.3: Matrizes elaboradas para Nova York, Los Angeles e Cidade do México, respectivamente. Fonte: The art of shaping the metropolis, pág. 98.

Conforme o exposto, a seguir será demonstrado o processo de construção do metromatriz system para o vetor noroeste paulista. Inicialmente foram demarcados alguns importantes elementos topográficos como a Serra da Mar, a Serra da Mantiqueira e a Serra do Japi, que fragmentam e limitam a expansão urbana da macrometrópole paulista.

Concomitante à identificação desses elementos foram estabelecidas as principais conexões viárias e eixos econômicos que se relacionam com o vetor. Dois vetores são fundamentais para a região: o primeiro é o próprio vetor noroeste, que conecta a macrometrópole paulista com todo o interior do país. O segundo, é o eixo Rio -São PauloCuritiba que, conforme visto, conecta a macro metrópole com o sul e o norte do pais.

A partir desses dois eixos econômicos principais, derivam-se outras importantes conexões estaduais com estados vizinhos, como o eixo Rio-Goiás passando Minas Gerais, O eixo Paraná-Matogrosso, e o eixo, Mato Grosso do Sul Goiás. Como se trata de uma matriz geométrica ela foi traçada de forma ortogonol.

A partir dos principais eixos de conexão estabelecidos são traçadas linhas paralelas que permitem a construção de uma malha, e a consolidação de unidades de gestão territorial; no caso da região em estudo de aprox. $100 \mathrm{~km}$.

Essas linhas tem a função de limitar o território de estudo e também de servir como base para o planejamento de novas infraestruturas de transporte no futuro.

Isso não significa que as infraestruturas existentes e futuras precisem obedecer de maneira exata a essa configuração ortogonal e reticular, pois ela é abstrata e sistêmica; 
porém devem ser previstas conexões eficientes para cada unidade territorial e para isso, deve se considerar as diretrizes dessas linhas de apoio.
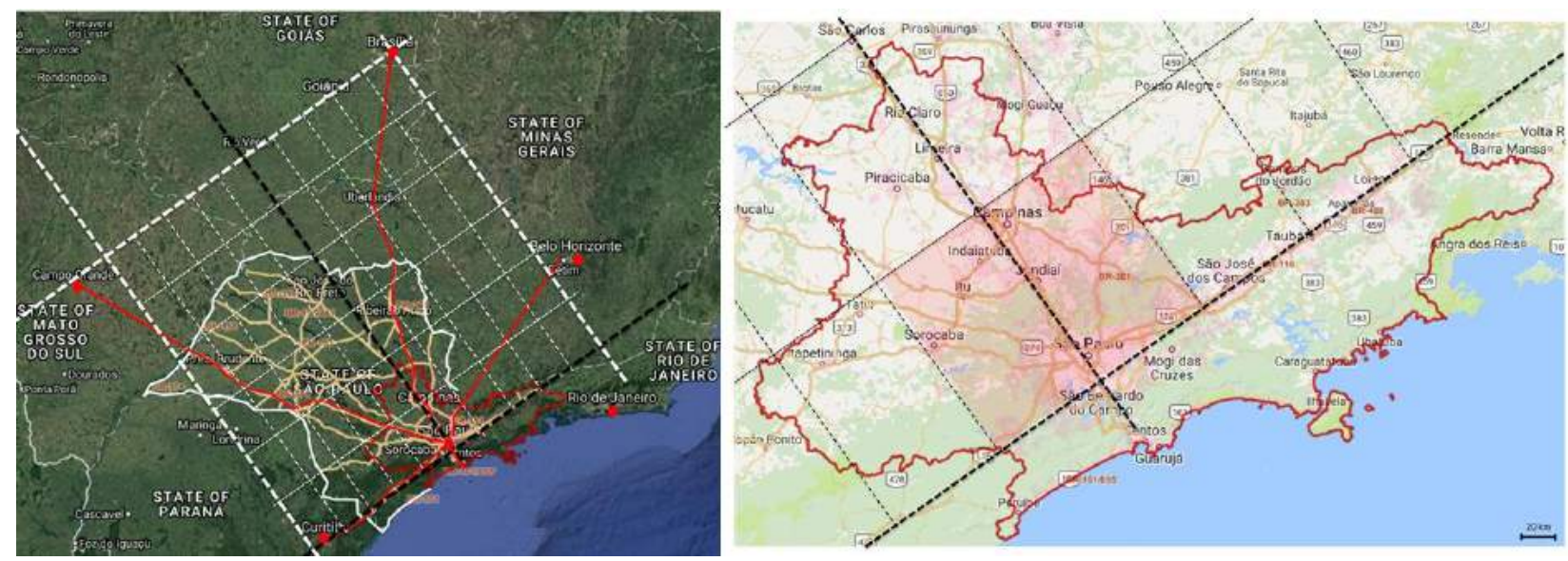

Figura 5.4: Matrix System. Limites geográficos e eixos de conexão do estado e da macrometrópole de SP. Fonte : Elaborado a partir de base Emplasa - http://www.emplasageo.sp.gov.br/.

Vários autores discutem qual a dimensão adequada de uma unidade territorial para seu eficiente planejamento territorial, essa pesquisa não se aprofundará nessa questão. No entanto, devido à dimensão macro metropolitana da metrópole paulista e do vetor em estudo, ao se ampliar a matriz principal, a fim de visualizar a unidade territorial que engloba o vetor noroeste paulista, notou-se a necessidade estabelecer uma nova matriz, secundária, inserida na unidade territorial inicialmente configurada.

Esta segunda matriz foi estabelecida considerando novamente as áreas verdes mais relevantes existentes na região como Serra do Japi, Serra Cantareira e a Zona de Proteção Ambiental de Campinas.

Observa-se que novos elementos topográficos secundários surgem na nova escala. Além disso, foram contemplados os eixos de conexão secundária, viário e férreo ( Rodovia Dom Pedro, Rodovia Santos Dumont, e linha férrea da companhia paulista), bem como as aglomerações urbanas e metropolitanas que se relacionam com o vetor noroeste.

As imagens abaixo demonstram a ampliação da área de estudo (vetor noroeste) e sua inserção e subdivisão dentro de um módulo de unidade e gestão territorial.

Ao mesmo tempo, sintetizam os subsistemas contínuos, infraestrutura (transporte e assentamento urbano) e áreas verdes, a fim de que se tornem compatíveis no futuro, pois ambos abrangem áreas contínuas do território. 


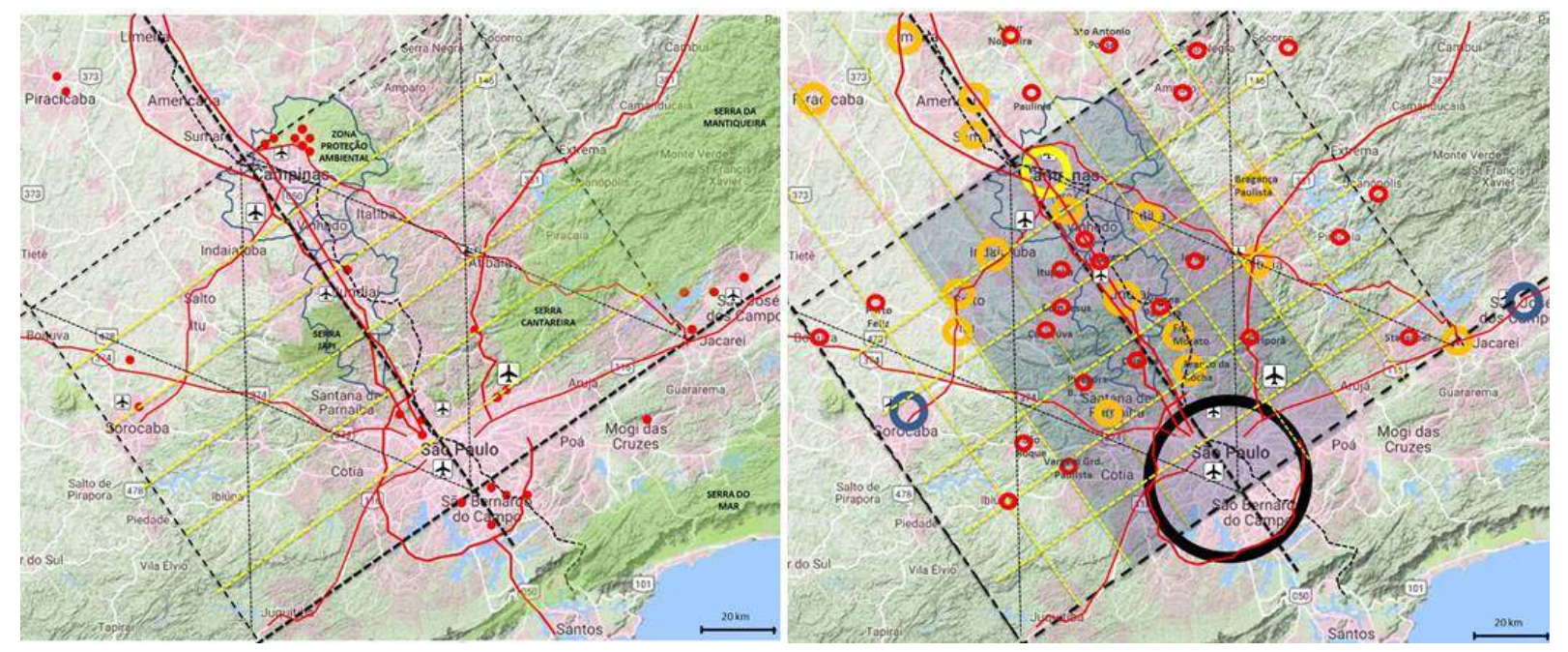

Figura 5.5: Sintetizando áreas verdes, eixos secundários e aglomerações urbanas e metropolitanas.

Fonte: Elaborado a partir de base Emplasa - http://www.emplasageo.sp.gov.br

Após a compatibilização entre a infraestrutura verde e a infraestrutura cinza ( conexões e centros urbanos), readequou-se a malha da matriz conforme a topografia local existente e apontou-se as localizações ou centralidades com potencial para Tod's-Transit Oriented Development, ou para o desenvolvimento Orientado à Transporte Sustentável (DOTS). Conforme Ortiz (2013) essas centralidades foram definidas tendo em vista sua conexão direta com as linhas férreas existentes.

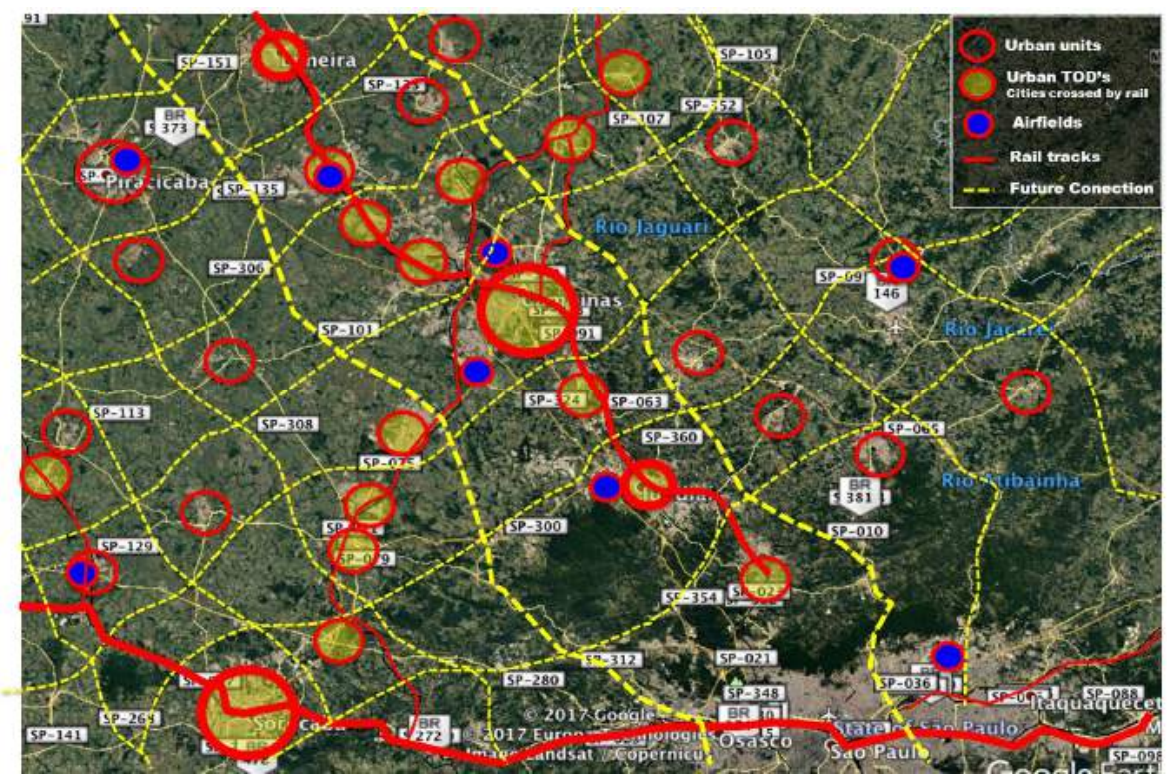

Figura 5.6: Rede de Conexões e centralidades para Transporte Orientado Sustentável - DOTS.

Fonte: Elaborado por Pedro Ortiz a partir de base google

Após a definição e síntese da matriz se inicia a terceira etapa da metodologia, que visa elaborar uma proposta ou um plano de ação regional para o desenvolvimento sustentável desse eixo produtivo regional. 
A seguir são apontadas algumas diretrizes deste plano:

O contínuo aumento das faixas de rolagem do Sistema Anhanguera/Bandeirantes, deve ser substituído pelo fortalecimento de todas as possibilidades de conexão transversal para reduzir o fluxo de mobilidade neste corretor produtivo nacional ,quase colapsado, e assim, fortalecer a integração do Triângulo Metropolitano.

Segundo análise de Ortiz, essas estradas mais cedo ou mais tarde estarão colapsadas. Quando o Brasil atingir 20.000 USD PIB per Cap, a produção e o tráfego serão o dobro do atual. Quando o Brasil alcançar 40.000 USD PIB per Cap., teremos que construir novas infrastruturas, paralelas ao sistema Anhanguera Bandeirantes. O plano aponta um planejameno futuro de tal forma que saibamos onde e quando será necessário implantar novas infraestruturas e nunca antes ou tardiamente.

Segundo Ortiz, falta fortalecer transversais para integrar e fornecer o acesso à instalações sociais pelas populações marginais que não tem condições de viver no corredor produtivo. Além disso, permitir a integração das insfraestruturas de transporte com áreas protegidas, e a demarcação de um limite claro para o desenvolvimento de ambas.

Portanto, o plano propõe além da implantação de infraestruturas de transporte complementares à existente (linhas amarelas derivadas da matriz principal), promover a sua integração com novas áreas verdes e de preservação, bem como áreas de expansão urbana, que garantirão o desenvolvimento equilibrado desse importante eixo produtivo da macrometrópole paulista, que se insere em um sistema global de conexões.

Implementar um corredor verde que integre as áreas ambientais mais relevantes da região: Serra da Cantareira, Serra do Japi e Área de Preservação Ambiental de Campinas, tendo em vista a proteção do rio Atibaia, que fornece água para toda a região, e também a preservação das áreas rurais da expansão urbana.

Propor orientações urbanas e econômicas para desenvolver um eixo histórico de preservação e turismo relacionado ao circuito de frutas ao longo da linha ferroviária, setor agrícola que remete ao passado desses municípios. Propor diretrizes urbanas que transformem o eixo da estrada de Boiada em um grande eixo de desenvolvimento de usos ligados ao setor de serviços, conforme tendência observada.

Propor diretrizes urbanas para as cidades de pequeno porte para implementação de parques e moradias, dentro das áreas industriais situadas ao longo da via Anhanguera. Viabilização da Implementação de uma nova infraestrutura de transporte, no corredor principal para complementar a infra-estrutura nacional e global, como o Trem Intercidades. 

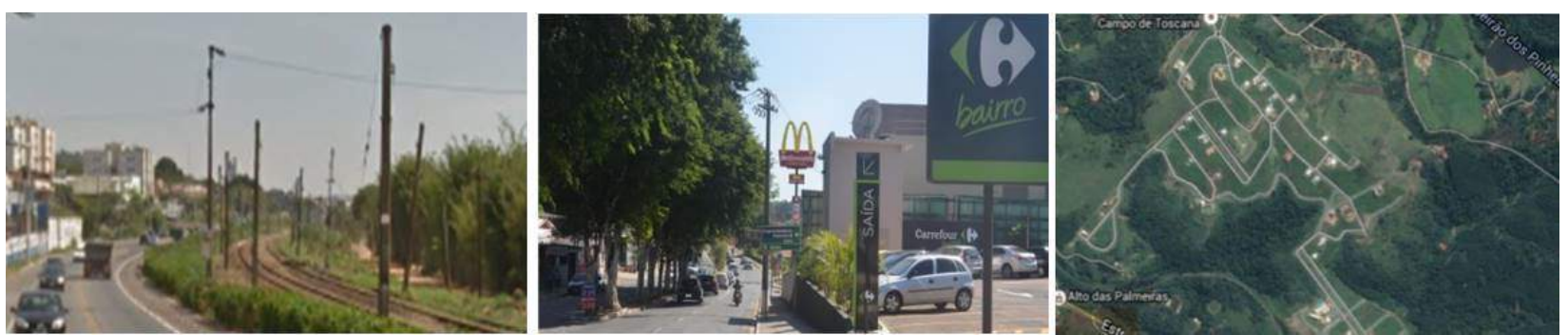

Figura 5.7: Linha Férrea, Eixo urbano de serviços na antiga Estrada Boida , Condomínios Residenciais. Fonte: www.googlemaps.com.br

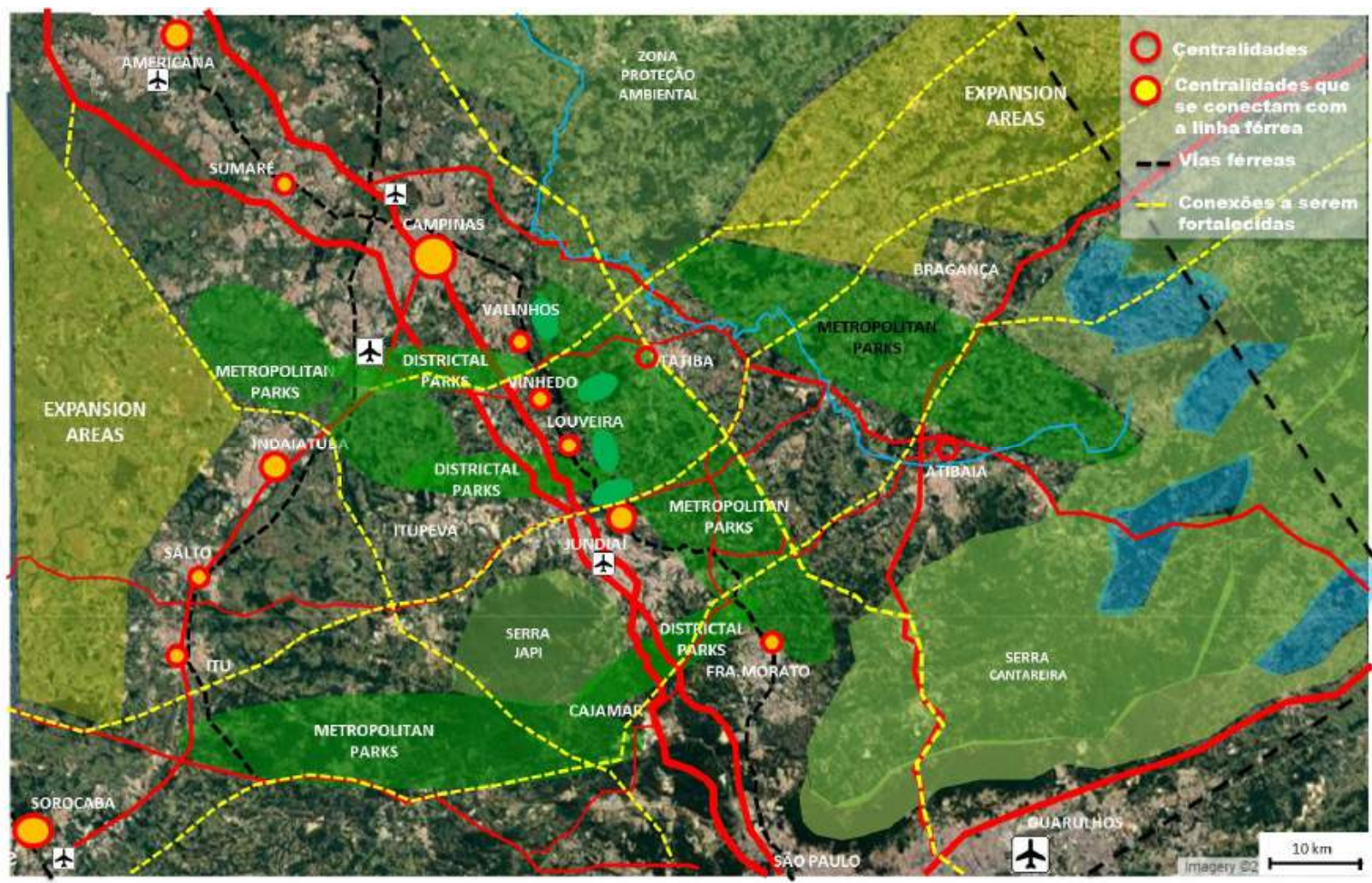

Figura 5.8: Área estendida: Síntese da Matrix - Green and Gray Infrastructure.

Fonte: Elaborado a partir de base Emplasa.

Tendo em vista o exposto e conforme conceituado por Viganò (2010), foi proposto aqui um espaço de abstração, ao mesmo tempo, conceitual, onde relações de proximidades estão presentes, e oferecem uma contribuição para estruturar ou repensar, em uma nova etapa, projetos urbanos de alcance mais abrangente, regional e nacional, ou seja, capazes de requalificar territórios metropolitanos, a partir da escala local.

Segundo a autora, métodos como esse se inserem em um processo de retomada da modernidade como um processo de objetivação. Apresenta-se- aqui não apenas uma metodologia projetual, mas a configuração de um espaço de representação onde relações e conflitos são inseridos e articulados. Esse espaço se apresenta como uma contribuição para a construção de um conhecimento através do projeto. 


\section{Considerações Finais.}

Relações contínuas de produção, troca e consumo, definem o espaço capitalista. Os avanços tecnológicos e as infraestruturas, ao mesmo tempo, que são estrategicamente previstos para suportar e ampliar constantemente essas relações capitalistas, estruturam esse espaço.

Além de reconfiguração e expansão urbana, as infraestruturas produzem novas localizações e valorização Imobiliária. Portanto o investimento em infraestrutura, é uma outra forma de gerar valor de troca, através do mercado imobiliário, e não apenas através da produção, o que gera desigualdades territoriais.

A partir do exposto, sucessivas transformações e reconfigurações urbanas, com ênfase para a década de 2000, acometeram o vetor noroeste paulista, eixo São-Paulo-Campinas, atualmente estruturado pelo sistema de rodovias Anhanguera/Bandeirantes, desde 1998, administrado por uma empresa privada, a CCR Autoban.

Como visto, diferentes ciclos econômicos suportados pela evolução técnica e estratégica das infraestruturas de transporte e comunicação permitiram a extensão das relações sociais e um contínuo avanço no processo de urbanização desse eixo histórico, desde o século XVIII, responsável pelo deslocamento de riquezas entre o interior, a capital e o porto de Santos, que se transformou no mais importante vetor econômico do país.

Os caminhos abertos para alcance do ouro e produtos agrícolas, a linha férrea para o transporte da produção cafeeira, as autoestradas suportando a industrialização, as transformações viárias previstas para atender à desconcentração da Indústria, aliadas as novas tecnologias de comunicação que permitem a reestruturação da produção, a fragmentação industrial, a dispersão urbana e finalmente do setor de serviços, constituem um território marcado por diferentes temporalidades, escalas territoriais ampliadas e tecidos urbanos que se sobrepõem.

A justaposição e extensão de escala, de uma ocupação territorial rural, campo-cidade, para uma ocupação industrial urbana, a seguir metropolitana, depois macrometropolitana e finalmente regional, corresponde à reterritorialização contemporânea. Relações espaciais sobrepostas, e estendidas, que transpõem limites municipais e metropolitanos estabelecidos, caracterizam a atual configuração do vetor noroeste paulista, que aqui denomino de novos Territórios Metropolitanos. 
Estruturado pelo corredor de riqueza, Anhanguera/Bandeirantes, estrategicamente previsto para suportar um novo arranjo produtivo, esse território metropolitano se constitui por municípios com forte integração territorial e espacial.

Essa integração é garantida do ponto de vista territorial pela continuidade de seu tecido urbano e do ponto de vista espacial pela intensificação de seus fluxos de deslocamento.

Do ponto de vista da escala local ou do território, a intensificação das dinâmicas de dispersão, agora mais relacionados ao setor de serviços, leva a coesão das partes de um todo fragmentado e a constituição de um novo arranjo metropolitano.

A industrialização, na segunda metade no século $X X$, sua dispersão a partir da década de 1970, devido à universalização dos mercados e dos modos de produção, e finalmente, a intensificação das dinâmicas de dispersão, no século XXI, devido à universalização dos modos de consumo padronizados, correspondem aos avanços da economia capitalista.

No novo século, a busca por qualidade e menor custo de vida, agora facilitados pela incorporação das tecnologias de comunicação e pela dispersão dos serviços, que replicam usos até então exclusivos dos grandes centros, possibilitam relações de trabalho, moradia, consumo e laser distantes dos núcleos metropolitanos, como Campinas e São Paulo.

Modos de vida contemporâneos, ou, relações que passam a ocorrer em escalas ampliadas, configuram novos tecidos, formas e dimensões territoriais.

Decorrente deste processo, ou dos avanços da economia capitalista, a partir do século XXI, configura-se no vetor noroeste um novo território metropolitano que apresenta uma nova condição de ocupação territorial, e que se origina a partir da integração dos territórios dispersos, vigentes no século XX.

Categorias de análise, como integração, porosidade, coesão e continuidade territorial, são alteradas e redefinidas, modificando em alguns aspectos o padrão de ocupação dos tecidos urbanos dispersos.

Enquanto as dinâmicas de dispersão urbana produziram ao longo do século XX novas extensões e escalas territoriais, sua intensificação a partir do século XXI tem promovido coesão e continuidade territorial. Características de esgarçamento do tecido urbano já não caracterizam mais os territórios metropolitanos contemporâneos. Dispersão e porosidade, espaço edificado e vazio urbano, apresentam diluição de seus contrastes.

Essa releitura foi revelada, tendo como objeto empírico de estudo o tecido urbano de municípios de menor porte (Valinhos, Vinhedo, Louveira e Cajamar) localizados no vetor 
noroeste, onde, devido a sua recente formação, evidencia-se um tecido constituído predominantemente por dinâmicas dispersas e novos usos relacionados aos avanços da economia capitalista.

Observou-se no tecido urbano desses municípios uma nova configuração morfológica que se diferencia tanto da continuidade espacial produzida em áreas urbanas que se expandem de forma tradicional, a partir de um núcleo ou centro metropolitano, como também da descontinuidade territorial e espacial encontrada inicialmente em tecidos urbanos impactados pelas dinâmicas de dispersão urbana.

Atraído por usos como condomínios horizontais, cadeias de serviço e a indústria moderna, que se desenvolvem de forma linear, o tecido urbano desses municípios é gradativamente consolidado através do preenchimento dos espaço intersticiais resultantes de dinâmicas anteriores de dispersão urbana. Ou seja, constituído inicialmente por uma porosidade natural, que o estrutura e o diferencia, esse tecido vem sendo gradativamente preenchido por novos usos ligados à economia moderna, produzindo vazios residuais, que gradativamente tendem a desaparecer.

Não se trata mais da constituição de tecidos através de um crescimento contínuo, linear ou a partir de um centro, mas sim a partir da junção de ocupações dispersas, que surgem muitas vezes anteriores à consolidação de áreas centrais.

Aos poucos essa integração de áreas dispersas definiu um novo território metropolitano que é desconectado de uma centralidade específica e principal, mas abastecido por diferentes centralidades menores que the dão suporte urbano, e que podem inclusive pertencer a outro limite administrativo.

Portanto, as dinâmicas de dispersão urbana devem ser entendidas como um estágio que faz parte de um processo mais amplo que vem levando a outras formas mais avançadas de urbanização que apresentam maior continuidade e coesão territorial, embora ainda constituam territórios segregados que isolam e excluem áreas menos favorecidas.

Os municípios de Valinhos, Vinhedo e Louveira e Cajamar, embora apresentem um PIB pouco significativo do ponto de vista estadual, apresentam os maiores índices estaduais de qualidade de vida, PIBs per capita, e taxas de crescimento, apresentando grande atratividade, e perspectiva de ascensão econômica e desenvolvimento urbano.

Além da alteração de aspectos morfológicos, a intensificação das dinâmicas de dispersão urbana e a ascensão do setor de serviços, agora mais atraídos pelas vantagens 
locacionais que o vetor noroeste oferece, fortalece esse eixo produtivo e intensifica fluxos de descolamentos, levando a configuração de um novo arranjo produtivo neste território.

Do ponto de vista espacial a intensificação de fluxos socioeconômicos entre a capital e Campinas, leva no século XXI, a transição da geografia da economia paulista do $A B C D$ paulista para o vetor noroeste paulista, ou seja, o segundo maior PIB do estado, deslocase da região metropolitana para a macrometrópole paulista.

Duas importantes e históricas regiões produtivas do estado de São Paulo, estruturadas pela evolução de suas redes de infraestrutura viárias, uma a partir das décadas de 1950/1970, em um contexto industrial e metropolitano (ABCD Paulista), e a outra, a partir da década de 1970, em um contexto pós-industrial e regional, vetor noroeste paulista.

Devido ao impacto que o processo global de reestruturação produtiva acarretou na transformação da complexa estrutura industrial do ABCD Paulista, seu tecido urbano, consolidado em outro período e contexto socioeconômico, apresenta também alterações morfológicas como a presença de áreas esvaziadas, e uma consequente porosidade urbana, que emerge em decorrência do fim de um ciclo econômico.

Tanto $\circ$ ABCD paulista como o vetor noroeste refletem em sua morfologia urbana diferentes contextos que devem ser reconhecidos para a adequada ocupação de suas áreas intersticiais, sejam elas, estruturais, residuais ou esvaziadas, ainda capazes de requalificar esses territórios metropolitanos impactados por economias e deseconomias de aglomeração.

Ou seja, essa porosidade além de se referir ao quadro físico e natural de cada território, com características próprias de densidade, área, relevo, resulta de transformações mais complexas no âmbito econômico e social.

Portanto o entendimento desse contexto mais amplo é fundamental para a promoção de novos usos, capazes de atuar em diferentes escalas, requalificando e reordenando os territórios metropolitanos contemporâneos ainda fragmentados.

Não existe uma relação direta entre a transição do segundo PIB estadual do ABCD para o vetor noroeste paulista, ou, entre o arrefecimento e a ascensão econômica dessas duas regiões do estado, pois bibliografias já demonstraram que a desconcentração industrial do ABCD Paulista se deu rumo a diferentes estados e regiões, dentre estas o vetor noroeste.

Porém, essas duas importantes regiões do estado, que não apresentam limites territoriais contíguos, são frutos de economias e deseconomias de aglomeração, produzidos por um 
mesmo processo de reestruturação produtiva capitalista, que levou à extensão de escalas e ao deslocamento das relações espaciais da escala metropolitana para a escala regional.

Esse processo demonstra conflitos que relações econômicas e territoriais contemporâneas estabelecem de forma fugaz no território, produzindo escalas territoriais estendidas, ou novos territórios metropolitanos, que extrapolam limites administrativos estabelecidos e que apresentam grande complexidade espacial.

Além disso, a economia capitalista em sua busca constante por novos mercados, sempre suportada por infraestruturas ou corredores de riqueza, intensifica fluxos de deslocamentos e a conformação de novas dimensões espaciais, que embora ainda não apresentem integração territorial merecem reflexões.

Novas dimensões espaciais, como o triângulo metropolitano, estruturado por corredores rodoviários de riqueza nacional, rodovia Dom Pedro e a rodovia Santos Dumont, que se relacionam diretamente com a Região Metropolitana de Campinas e com o vetor Noroeste, devem ser considerados, dentro de um planejamento regional mais amplo, que considere a futura integração de todo esse território metropolitano.

Ou seja, apreender as partes deste todo disperso, juntar seus fragmentos e atuar em sua totalidade, prevendo extensões, e pensando na escala local a partir desta totalidade, é a forma de intervir nos novos territórios metropolitanos, evitando segregação territorial e fragmentação do espaço.

Para tanto, o entendimento do contexto mais amplo no qual novas configurações morfológicas estão sendo produzidas, objeto de estudo desta pesquisa, permite conseguir compreender as múltiplas relações espaciais que os novos Territórios Metropolitanos contemporâneos estabelecem.

A partir desse entendimento, a pesquisa sugere a construção de uma matriz (MetroxSystem), capaz evidenciar de forma sistêmica e hierárquica as múltiplas relações que uma região, um município, ou um espaço intersticial assume, dentro do território nacional.

Salienta-se aqui que essa matriz foi definida com base na análise e na produção de conhecimento construído nos capítulos I, II e III, e IV, que estamos falando de uma ferramenta facilitadora, cuja complexidade de construção, esta em sua fase de análise e síntese Ortiz (2014), ou conforme Viganó (2015), conceitualização e descrição.

Desta forma, esta metodologia permite atuar compatibilizando múltiplas escalas, indo além da importância da escala local e produzindo desenvolvimentos urbanos capazes 
efetivamente de requalificar o território de forma mais abrangentes, integrando-o ao invés de fragmentá-lo, e suprindo suas deficiências.

Através da matriz construída, observou-se que esses municípios de pequeno porte estrategicamente posicionados se relacionam também com a dimensão nacional e portanto, seus espaços devem ser pensados sob uma dimensão ampliada.

As diretrizes propostas sugerem um desenvolvimento orientado pelo fortalecimento de eixos transversais ao $\mathrm{SAB}$, e pela estimulação dos eixos lineares e históricos que estruturam esse território e preservam suas origens. Espaços de compartilhamento devem coexistir com os espaços de apropriação privada, ligados à economia moderna, amenizando desequilíbrios e a fragmentação do território.

Para tanto, além de um plano regional, faz-se necessária a elaboração de formas de governança que contemplem políticas públicas diferenciadas e mais abrangentes, que sejam capazes de promover uma ação coletiva sobre os ambientes construídos, garantindo a integração dos Territórios Metropolitanos Contemporâneos.

Além disso, o sistema Anhanguera-Bandeirantes, em 2018 completará 20 anos de concessão privada e será objeto de nova licitação. É imprescindível que agências reguladoras como Artesp, articuladas com outras instituições, exijam das concessionárias contrapartidas que contemplem muito mais que constantes obras de manutenção e evolução viária, que geram altos custos para a sociedade.

Acesso restrito à rodovia devido ao alto custo do pedágio, bairros que a rodovia segrega sem ofertar acessibilidade, manutenção de parques lineares e metropolitanos, preservação de áreas de expansão urbana, são questões a serem repensadas para um projeto mais amplo de requalificação urbana nacional, evitando que vetores de expansão capitalista que priorizam o fluxo ao invés do território, promovam a fragmentação do território, acirrando desigualdades entre corredores de riqueza e áreas de pobreza.

Em fim, planejamento regional que articule território e espaço; políticas públicas mais extensivas; e concessões privadas menos lucrativas e mais atentas ao território nacional, devem coexistir.

No que diz respeito ao planejamento regional, esta pesquisa se estrutura de forma a demonstrar a formatação de uma metodologia projetual, através do enfrentamento de três análises distintas, conceitual, descritiva e propositiva (VIGANÒ, 2010), que torna possível, a produção de conhecimento e a intervenção eficaz nas complexas dinâmicas e relações que compõem os Territórios Metropolitanos Contemporâneos. 


\section{Bibliografia Referenciada:}

ASCHER, François. Metápolis ou l'avenir des villes. Paris: Odile Jacob, 1995.

ANAU, Roberto Vital. As transformações econômicas no grande ABC de 1980 a 1999. Artigo publicado na Revista do programa de pós-graduação em arquitetura e urbanismo da fausp, Brasil. v. 11 (2002) - ISSN: 2317-2762.

BENTES, Júlio Cláudio da G. Dispersão Urbana no Médio Paraíba Fluminense. São Paulo, 2014, 431 p. Tese de Doutorado. FAU-USP.

BRENNER, Neil. Em prol de uma reconsideração do urbano e seu impacto global . In: Revista Eletrônica de Estudos Urbanos e Regionais. oㅜ 22, pg. 58 - 67, 2015.

BRENNER, Neil. A globalização como reterritorialização: o reescalonamento da governança urbana na União Européia. In: Cadernos Metrópole. São Paulo: EDUC, 2010. p. 295-605, v.12, n.24.

CAIADO, Maria Célia; PIRES, Maria Conceição. Expansão na Região Metropolitana de Campinas: dispersão e novas formas urbanas. In: REIS, N. G. (org). Brasil- Estudos sobre dispersão urbana. São Paulo: FAU-USP, 2007, p. 81-111.

CANO, Wilson. Raízes da Concentração Industrial em São Paulo. Campinas: UNICAMP, 1998.

CANO, W.; BRANDÃO, C. A. (Coordenadores). A Região Metropolitana de Campinas. Urbanização, economia, finanças e meio ambiente. Campinas: Editora da Unicamp, 2002.

CASTELLS, Manoel. A Sociedade em Rede. A Era da Informação: Economia, Sociedade e Cultura. São Paulo: Paz e Terra, 1999.

CONTIN, Antonella. Questo : metropolitan architecture. Santarcangelo di Romagna: Maggioli, 2015.

COSTA, Maria Tereza. Trem intercidades vai ter licitação. Correio Popular, 27 fevereiro 2018, Caderno Cidades, p. A4.

CUNHA, J. M. P. ; MIGLIORANZA, E.; Valinhos: um novo padrão de cidadedormitório In CUNHA, J.M.P (Org). Novas Metrópoles Paulistas. População, vulnerabilidade e segregação. NEPO/ Unicamp. Campinas, 2006.p. 539-560, 2006.

CUNHA, J. Marcos Pinto da et al. A mobilidade pendular na Macrometrópole Paulista: diferenciação e complementaridade socioespacial. Caderno Metrópole, vol.15, n.30, 2013, pp.433-459. 
DEÁK, Csaba e Schiffer, Sueli (Org, 1999) O processo de urbanização no Brasil. Edusp/Fapesp, São Paulo, 1999.

DEMATTEIS, Giuseppe. Suburbanización y periurbanización. Ciudades anglosajonas y ciudades latinas. In: Monclús, F.J. (ed.), La ciudad dispersa. Barcelona: Centre de Cultura Contemporânea de Barcelona, 1998.

DERSA. Síntese do Estudo de Uso e Ocupação do solo e Controle de Acessos para o Corredor Anhanguera/ Bandeirantes, 1980.

DOMINGUEZ, Alvaro (2001). Urbanização Extensiva - uma nova escala para o planejamento, in CITTA. 1st Anual Conference on Planning Research. FEUP , 30 maio, 2008. Porto.

DOMINGUES, Álvaro. Urbanização difusa em Portugal. Publicado In: REIS, N.; PORTAS, N.;TANAKA, M. Dispersão urbana: Diálogo sobre pesquisas. Brasil-Europa. São Paulo, FAU-USP, 2007. p. 215-243.

EIGENHEER; SOMEKH. Formas avançadas de dispersão urbana no vetor noroeste paulista: eixo São Paulo-Campinas. In Cadernos Metrópole, São Paulo, v. 19, n. 40, 2017, pp. 777-797.

EIGENHEER, Daniela. Do Espaço Metropolitano ao Regional: ABCD Paulista $x$ Vetor Noroeste. Artigo apresentado no III Enanparq, 2014, São Paulo. Publicado In: REIS, N. G.; BENTES, J. C. G. (orgs). Dez Anos de Diálogos Sobre Dispersão Urbana. São Paulo: FAUUSP, 2017, p.351-362.

EIGENHEER, Daniela. Tecnologia, Mobilidade e Dispersão Metropolitana: Sistema Anhanguera/Bandeirantes. São Paulo, 2011. 151 f. Dissertação (Mestrado) - Universidade Mackenzie.

EMPLASA. Macrometrópole Paulista dados e indicadores, 2013.

FONSECA, R. B.; DAVANZO, A. M. Q.; NEGREIROS, R. M. C. Livro Verde: Desafios para a Gestão da Região Metropolitana de Campinas. Campinas: NESUR-UNICAMP, 2002.

GHORRA-GHOBIN, Cynthia. La Métropolisation em Question, PUF, Paris, 2015.

GOTTDIENER, Mark. A Produção Social do Espaço. São Paulo, Editora Edusp, 1993.

HALL, Peter. Megaciudades, ciudades mundiales y ciudades globales. In: Lo urbano: en 20 autores contemporáneos. Ángel Martin Ramos, 2004, p.117-132. 
HARDER, Isabel C. F. Fruticultura e Desenvolvimento Urbano do Município de Louveira (SP). Tese (doutorado). Piracicaba-Escola Superior de Agricultura Luiz de Queiroz, 2007.

HARVEY, David. Condição Pós Moderna. São Paulo: Editora Loyola, 18 ed., 1992.

HARVEY, David. The urban process under capitalism. In: DEAR, M; SCOTT,A.

Urbanization and urban planning in capitalist society. Londres: Metheuen,1981.

HOLLAND, Stuart. Capital versus the Regions. Londres: Macmillan, 1976.

IBGE, Instituto Brasileiro de Geografia e Estatística. Arranjos populacionais e concentrações urbanas do Brasil. Rio de Janeiro: IBGE, 2016..

IBGE, Instituto Brasileiro de Geografia e Estatística. Censo Demográfico 2010. Aglomerados subnormais Informações Territoriais. Rio de Janeiro: IBGE, 2013.

INDOVINA, Francesco. La ciudad difusa. In: Lo urbano: en 20 autores contemporáneos. Ángel Martin Ramos, 2004, p.49 -59.

INDOVINA, Francesco. La città diffusa. Che cos"è e come si governa. Lettura 6.1 (Position Paper), Veneza, p. 124-131, 1997.

KLINK, Jeroen Johannes. A cidade-região: regionalismo e reestruturação no Grande ABC Paulista. Rio de Janeiro: DP\&A, 2001.

LANGENBUCH, Richard Juergen. A Estruturação da Grande São Paulo: estudo de geografia urbana.Rio de Janeiro: IBGE, 1971.

LENCIONI, Sandra. Urbanização difusa e a constituição de megaregiões. O caso de São Paulo-Rio de Janeiro. In: Revista Eletrônica de Estudos Urbanos e Regionais. no 22 , pg. $6-15,2015$.

LENCIONI, Sandra. O Processo de Metropolização do Espaço: Uma Nova Maneira de Falar da Relação entre Metropolização e Regionalização. In: SCHIFFER, S. R. (org). Globalização e Estrutura Urbana. São Paulo: Hucitec/FAPESP, 2004, p.153 -165.

MEYER, Regina M. Propseri. São Paulo e seus territórios urbanos contemporâneos. In Revista Iberoamericana de Urbanismo nำ12. Riurb, 2015, p 7-31.

MEYER, PEREIRA GALVAO e RUBIO LONGO. São Paulo e suas escalas de urbanização. In Revista Iberoamericana de Urbanismo no12. Riurb, 2015, p 1-6.

MEYER, R. M. P.; GRONSTEIN, M. D., BIDERMAN, C. São Paulo Metrópole. São Paulo: EDUSP: Imprensa Oficial do Estado de São Paulo, 2004. 
MITICA NETO, Hélio. Urbanização em Campinas: mudança no tecido urbano no entorno da rodovia Dom Pedro. São Paulo, 2008. Tese (Doutorado) - FAUUSP.

MONCLÚS, Francisco Javier. Suburbanización y nuevas periferias. Perspectivas geográfico-urbanísticas. Introducción. In: MONCLÚS, Francisco Javier (Ed.). La ciudad dispersa. Barcelona: Centre de Cultura Contemporània de Barcelona, 1998. P. 143-167.

NEGRI, Barjas. Concentração e desconcentração industrial em São Paulo (18801990). Campinas: Unicamp, 1996.

NOBRE, Eduardo A. C. Reestruturação econômica e território: expansão recente do terciário na maginal do rio Pinheiros. Tese (doutorado). São Paulo. Faculdade de Arquitetura e Urbanismo da UNiversidade de São Paulo, 2000.

ORTIZ, Pedro.The art of shaping the metropolis. McGraw-Hill Education. Europe, 2013.

PACHECO, Carlos Américo. Fragmentação da Nação. Campinas: UNICAMP, 1998

QUEIROGA, E.. F.; BENFATTI, D. M. Entre o nó e a rede, dialéticas espaciais contemporâneas - $O$ caso da metrópole de Campinas diante da megalópole do Sudeste do Brasil. Revista Brasileira de Estudos Urbanos e Regionais(ANPUR), v. 9, p. 41-52, 2007.

RAFFESTIN, Claude.Por uma Geografia do Poder. São Paulo: Editora Ática, 1993.

REIS, Nestor Goulart. Transcrição da disciplina AUH 5828. Questões de História da Urbanização. Profs. Nestor Goulart Reis Filho e Beatriz P.Siqueira Bueno. Ministrada de 23 a 31 de julho de 2015. FAU-Maranhão.

REIS, Nestor Goulart. O caminho do Anhanguera. São Paulo: Via das Artes, 2014.

REIS, Nestor Goulart. Um diálogo importante. Publicado In: REIS, N.; PORTAS, N.; TANAKA,M; (Org.). Dispersão urbana: Diálogo sobre pesquisas. Brasil-Europa. S.P., FAU-USP, 2007. p. 7-31.

REIS, Nestor Goulart. Notas sobre urbanização Dispersa e nova formas de tecido urbano. São Paulo: Via das Artes, 2006.

SANTOS, Milton. A natureza do espaço: técnica e tempo, razão e emoção. São Paulo: Hucitec, 1996.

SCHIFFER, Sueli. As Políticas Nacionais e a Transformação do Espaço Paulista 1955-1980. São Paulo, 1989. Tese (Doutorado) - USP. 
SCIOTA, Alessandra Argenton. Critérios de avaliação de morfologia urbana em modelos de segregação residencial. Tese (doutorado). Campinas: PUC-Campinas, 2016. 240p. Tese de Doutorado. PUCCAMP.

SCOTT, A.; AGNEW, J.; SOJA, E.; STORPER, M. Cidades regiões globais. In: Espaço e Debates: aliança e competição entre cidades. São Paulo: Neru, 2001, n. 41, p.11-25.

SEADE Fundação Sistema Estadual de Análises de Dados. Disponível em: <http://www.seade.gov.br.>. Acessado em: 25 de julho de 2012.

SECCHI, Bernardo. Cidade contemporânea e seu projeto. In: REIS Filho, Nestor Goulart (org.). Dispersão urbana: diálogo sobre pesquisas Brasil - Europa. Publicado In: REIS, N.; PORTAS, N.; TANAKA,M (coordenadores). Dispersão urbana. Diálogo sobre pesquisas. Brasil-Europa. São Paulo, FAU-USP, 2007. p.7-31

SECCHI, Bernardo. A cidade do século XX. São Paulo: Perspectiva, 2009.

SOMEKH, N; CAMPOS NETO, C. M. Desenvolvimento local e projetos urbanos. Vitruvius, 05.059, ano 5, 2005. Disponível em: <http://www.vitruvius.com.br>.

SOJA, Edward. Para além de postmetrolis. Revista UFMG ,ํำ 20, pg.137-167, 2013.

SOJA, Edward. Postmetropolis: Critical Studies of Cities and Regions. Oxford : Blackwell Publishers, 2000.

SPOSITO, M. E. B. Urbanização difusa e cidades dispersas: perspectivas espaçotemporais contemporâneas. In: REIS, Nestor Goulart (Org.). Sobre a dispersão urbana. São Paulo: Via das Artes/FAUUSP, 2009. P. 38-54.

SPOSITO, M. Encarnação Beltrão. Descontinuidades territoriais e novas morfologias urbanas no Estado de São Paulo. In: REIS, N.; PORTAS, N.; TANAKA,M; (Org.). Dispersão urbana: diálogo sobre pesquisas Brasil - Europa. 1a.ed.São Paulo: LAP FAU/USP, 2007, v. 1, p. 93-110.

VAINER, Carlos B. Planejamento territorial e projeto nacional. Os desafios fragmentação. Revista Brasileira de Estudos Urbanos e Regionais (ANPUR), v. 9, p. 9 23, 2007 VIGANÒ, Paola. I Territori Dell'Urbanistica. II progetto come produttore di conoscenza. Officina Edizion, Venezia, 2010. 


\section{Referências Bibliográficas:}

BAUM-SNOW, N. "Did Highways Cause Suburbanization?”. Massachusetts: Harvard College and Massachusetts Institute of Technology, Quartely Journal of Economics, 2007. BENASSI, Waldemar. DERSA 20 anos 1969 - 1989 Memória Técnica. São Paulo, 1889. BORJA, Jordi; CASTELLS, Manuel. The Local \& the Global: management of cities in the information age. Londres: Earthscan, 1998.

CANO, Wilson; SEMEGHINI, Ulysses. São Paulo no limiar do século XXI: Diagnósticos Setoriais da Economia Paulista.São Paulo: Fundação SEADE, 1992, 2 v.

CANO, W.; PACHECO, C. A.; ZIMMERMANN, G.; SEMEGHINI, U. São Paulo no limiar do século XXI -Cenários da Urbanização Paulista. São Paulo: F.SEADE, 1992, 5v.

CNT, Confederação Nacional do Transporte. Transporte em Transformação XIII. Trabalhos vencedores do Prêmio CNT Produção Acadêmica 2008, 2009.

CASTELLS, Manuel; HALL, Peter. Technopoles of the World: The making of twenty-fistcentury industrial complexes. Routledge, 1994.

DERSA. II Seminário DERSA Rodovia dos Bandeirantes 6-11a 10-11/1978. Secretaria de Estado dos Negócios dos Transportes - São Paulo, 1978.

DERSA. Dersa 20 anos 1969 -1989 Memória Técnica, 1989.

EMPLASA. Dinâmica da Macrometrópole Análise Introdutória. Relatório fornecido pela Emplasa, 1993.

EMPLASA. Transporte de Interesse Regional na Macrometrópole de São Paulo: Transporte Ferroviário e Metroviário, 1992, 2 v.

FERREIRA, João Sette Whitaker. Estudo Preliminar Impactos Urbanísticos do Trecho Oeste do Rodoanel Mario Covas. LABHAB - Laboratório de Habitação e Assentamentos Humanos da Faculdade de Arquitetura e Urbanismo da Universidade de São Paulo, 2005.

LEFEBVRE, Henri. A revolução urbana. Belo Horizonte: Editora da UFMG, 1999 [1970]. LENCIONI, Sandra. Reestruturação Urbano-Industrial no Estado de SP: A Região da Metrópole Desconcentrada. In: Espaço e Debates. SP: NERU, 1994, n.38, p.54-61.

MEYER, R. M. P.; RAMALHO, T. M. T.; CRUZ, M. F. Mobilidade Viária Versus Contexto Urbano. In: SCHICCHI, M. C.; BENFATTI, D. (orgs). Urbanismo: Dossiê São Paulo - Rio de Janeiro. Campinas: PUCCAMP/PROURB, 2004, p.163-176. 
MACIEL, Vladimir Fernandes. Dando Voltas: Efeitos Econômicos da Implantação de uma nova Rodovia - o caso do Rodoanel metropolitano de São Paulo. São Paulo, 2011. Tese (doutorado) - Escola de Administração de Empresas de São Paulo.

REIS, Nestor Goulart. Memória do Transporte Rodoviário. São Paulo:CPA Consultoria de Projetos, 2003.

ROLNIK, R. ; SOMEKH, Nádia . Governar as Metrópoles: dilemas da recentralização. São Paulo em Perspectiva, São Paulo, v. 14, n. 04, 2002.

SASSEN, Saskia. Sociologia da Globalização. São Paulo: Editora Artmed, 2010.

SCHIFFER, Sueli. Globalização e Estrutura Urbana. São Paulo: Hucitec/FAPESP, 2004.

SEMEGHINI, Ulysses. São Paulo no limiar do século XXI - Cenários da Urbanização Paulista.São Paulo: Fundação SEADE, 1992, 8 v.

SOMEKH, Nadia. A Cidade Vertical e o Urbanismo Modernizador.SP: Edusp,1997.

VILLAÇA, Flávio. Espaço Intra-urbano no Brasil. S.P: Studio Nobel/FAPESP, 2001.

\section{Webgrafia:}

- Emplasageo - Geoinformação ao Cidadão. Disponível em <http://.emplasageo.sp.gov.br>. Último acesso em 20 fevereiro 2018.

- Prefeitura Municipal de Valinhos. Disponível em <http://www.valinhos.sp.gov.br>. Acesso em 16 de março 2017.

- IBGE Cidades - Valinhos História e Fotos. Disponível em: <http://www.cidades.ibge. gov.br /v4/ brasil/sp/valinhos/historico>. Acesso em 07 abril. 2017.

- IBGE Cidades - Cajamar. Disponível em https://cidades.ibge.gov.br/brasil/sp/cajamar/historico. Acesso em 18 de novembrojaneiro de 2017.

- Prefeitura Municipal de Vinhedo-História da Cidade. Disponível em <http://www.vinhedo.sp. gov.br/cultura-e-turismo/historico-da-cidade>. Acesso em 20 de fevereiro 2017.

- Inova Cajamar, Seade. Disponível em <http://inovacajamar.org.br/site/historia/>. Acesso em 10 de novembro 2017.

- Cidade-Prefeitura de Cajamar. Disponível em $<$ http://www.cajamar.sp.gov.br/v2/?exibe= cidade>. Acesso em 12 de dezembro de 2018.

- Corredor Ayrton Senna/Carvalho Pinto. Disponível em: <http://www.ecopistas.com.br/ institucional/corredor-ayrton-senna-carvalho-pinto >. Acesso em 15 de janeiro 2018.

- Pacote promete aliviar rodovias de SP até férias de julho - Infográfico/Estadão, 12 Set. 2014. Disponível em: <http://www1.folha.uol.com.br/ cotidiano/1244674>. Acesso 16 de set 2016.

- Fundação Seade - Cajamar História. Disponível em <http://www.perfil.seade.gov.br/ historico $>$. Acesso em 16 de set de 2016.

- EXAME/Conheça os principais corredores da riqueza no Brasil. Disponível em $<\underline{\text { https: }}$ //exame.abril.com.br/revista-exame/corredores-da-riqueza/>. Acesso 12 janeiro de 2018.

- CORREIO POPULAR - Trem intercidades vai ter licitação. Disponível em: $<$ http://correio.rac. com.br/ conteudo/2018/02/campinas e rmc/528850-trem-intercidades-vai-ter-licitacao.html>. Acesso 28 fev. 2018. 


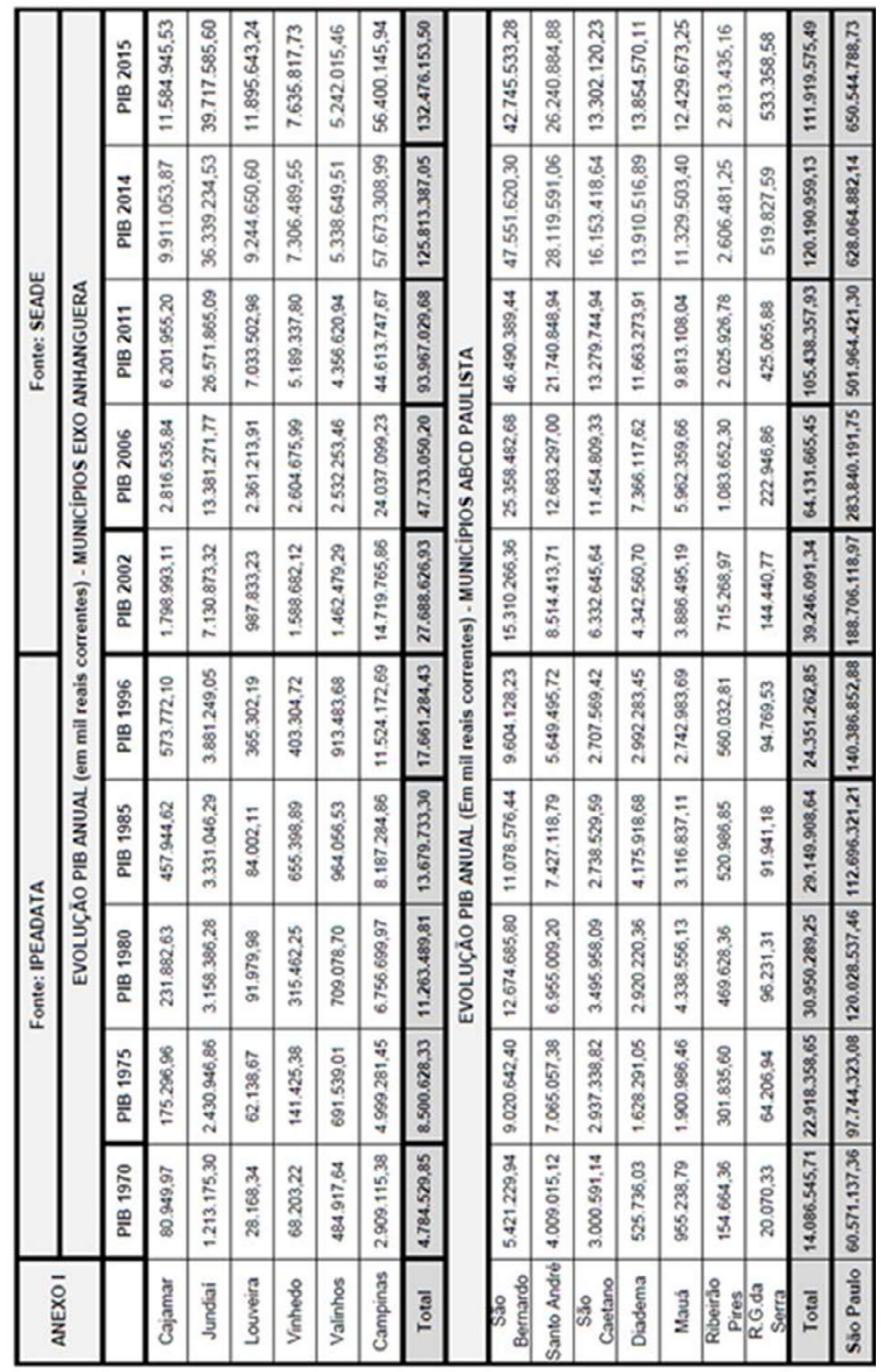




\begin{tabular}{|c|c|c|c|c|c|c|c|c|c|c|c|}
\hline \multirow{2}{*}{\multicolumn{2}{|c|}{ ANEXO II }} & \multicolumn{5}{|c|}{ IPEADATA } & \multicolumn{5}{|c|}{ SEADE } \\
\hline & & \multicolumn{10}{|c|}{ Evolupso VA" - MUNICIPIOS EDXO ANKANOUERA - Fonto IEADE O IPEADATA } \\
\hline vusucipos & seton & 1970 & 1975 & 1980 & 1985 & 1996 & 2002 & 2006 & 2011 & 2014 & 2015 \\
\hline \multirow{4}{*}{ Cajamar } & Agropecuaria & $0,78 \%$ & $2.26 \%$ & $0,66 \%$ & $0,80 \%$ & $0,00 \%$ & 0.03 & 0,13 & 0,01 & 0 & 0 \\
\hline & indostria & $81,43 \%$ & $59,29 \%$ & $80.93 \%$ & $57.64 \%$ & $76,79 \%$ & 58,90 & 61,49 & 36.05 & 24,54 & 21,67 \\
\hline & Servicos & $17,79 \%$ & $38,45 \%$ & $18,41 \%$ & $41,55 \%$ & $23.21 \%$ & 41,08 & 38,37 & 53,93 & 75,46 & 78,33 \\
\hline & PIO Tola & $100 \%$ & $100 \%$ & $100 \%$ & $100 \%$ & $100 \%$ & 100,01 & 99,99 & 99,99 & 100,00 & 100 \\
\hline \multirow{4}{*}{ Jundiai } & Agropecuaria & $2,45 \%$ & $1,56 \%$ & $0.21 \%$ & $1,35 \%$ & $0.55 \%$ & 0,59 & 0,33 & 0,28 & 0,41 & 0.37 \\
\hline & Indostra & $61,21 \%$ & $61,07 \%$ & $68,35 \%$ & $69.11 \%$ & $56,85 \%$ & 35,81 & 32,06 & 33.68 & 28,36 & 25,51 \\
\hline & Servops & $36,34 \%$ & $37.37 \%$ & $31,44 \%$ & $29,34 \%$ & $42,60 \%$ & 63,61 & 67,62 & 66,04 & 71,24 & 74,12 \\
\hline & Plo Total & $100 \%$ & $100 \%$ & $100 \%$ & $100 \%$ & $100 \%$ & 100,00 & 100,01 & 100.00 & 100.01 & 100 \\
\hline \multirow{4}{*}{ Louveira } & Agropecuarta & $44,22 \%$ & $31,07 \%$ & $8,98 \%$ & $12,76 \%$ & $3,50 \%$ & 1,81 & 0,85 & 0,30 & 0,41 & 0,31 \\
\hline & Indostria & $25,77 \%$ & $42,07 \%$ & $57,11 \%$ & $56.45 \%$ & $84,71 \%$ & 36.20 & 45.59 & 47.72 & 32,29 & 24,96 \\
\hline & Servoços & $30,01 \%$ & $26,86 \%$ & $33,91 \%$ & $30.79 \%$ & $11,79 \%$ & 61,99 & 53,56 & 51,99 & 67,31 & 74,73 \\
\hline & Plo Total & $100 \%$ & $100 \%$ & $100 \%$ & $100 \%$ & $100 \%$ & 100.00 & 100,00 & 100.01 & 100.01 & 100 \\
\hline \multirow{4}{*}{ Vinhedo } & Agropecuarta & $11,87 \%$ & $7,29 \%$ & $1,93 \%$ & $1,49 \%$ & $0,73 \%$ & 0,97 & 0,74 & 0,28 & 0.27 & 0.22 \\
\hline & Industria & $61.25 \%$ & $67,17 \%$ & $73,67 \%$ & $81,77 \%$ & $56,48 \%$ & 51,93 & 56,77 & 51,08 & 42,38 & 39,81 \\
\hline & Servopos & $26,88 \%$ & $25,53 \%$ & $24,40 \%$ & $16,74 \%$ & $42,79 \%$ & 47,10 & 42,49 & 48,65 & 57.35 & 59,98 \\
\hline & Plo Totas & $100 \%$ & $100 \%$ & $100 \%$ & $100 \%$ & $100 \%$ & 100,00 & 100,00 & 100.01 & 100,00 & 100,01 \\
\hline \multirow{4}{*}{ Valinhos } & Agropecuarla & $2.25 \%$ & $2,65 \%$ & $3.56 \%$ & $2,03 \%$ & $1,88 \%$ & 1,01 & 0,67 & 0,60 & 0,83 & 0,88 \\
\hline & Indostria & $69,03 \%$ & $81,32 \%$ & $71,46 \%$ & $76,26 \%$ & $60,66 \%$ & 45,72 & 46,46 & 39,41 & 31,58 & 30,93 \\
\hline & Servipos & $28,72 \%$ & $16,03 \%$ & $24,97 \%$ & $21.71 \%$ & $37,46 \%$ & 52.28 & 52,87 & 59,99 & 67.6 & 68,19 \\
\hline & Plo Tota: & $100 \%$ & $100 \%$ & $100 \%$ & $100 \%$ & $100 \%$ & 100,01 & 100,00 & 100,00 & 100,01 & 100 \\
\hline \multirow{4}{*}{ Campinas } & Agropecuaria & $1,80 \%$ & $1,11 \%$ & $0,78 \%$ & $1,02 \%$ & $0,16 \%$ & 0,31 & 0,31 & 0,17 & 0,23 & 0.24 \\
\hline & Indostria & $39.78 \%$ & $55,13 \%$ & $51,41 \%$ & $52.59 \%$ & $35,80 \%$ & 27,44 & 27,24 & 23,65 & 19,87 & 20,85 \\
\hline & Servicos & $58,41 \%$ & $43,76 \%$ & $47,81 \%$ & $46.39 \%$ & $64,04 \%$ & 71,99 & 72,45 & 76.19 & 79.9 & 78,92 \\
\hline & PO Total & $100 \%$ & $100 \%$ & $100 \%$ & $100 \%$ & $100 \%$ & 99,74 & 100,00 & 100,01 & 100,00 & 100,01 \\
\hline \multicolumn{12}{|c|}{ Evolup̧so VA - MUNICIPIOS ABCO PAULISTA } \\
\hline \multirow{4}{*}{$\begin{array}{l}\text { S.Bernado do } \\
\text { Campo }\end{array}$} & Agropecuaria & $0,03 \%$ & $0,06 \%$ & $0,05 \%$ & $0,05 \%$ & $0,01 \%$ & 0,02 & 0,01 & 0,01 & 0.02 & 0.02 \\
\hline & Indostria & $66,11 \%$ & $68,73 \%$ & $73.57 \%$ & $72.20 \%$ & $62,10 \%$ & 44,04 & 46,59 & 41,15 & 33.5 & 27.75 \\
\hline & Servipos & $33,81 \%$ & $31,21 \%$ & $26,39 \%$ & $27.73 \%$ & $37,90 \%$ & 55,94 & 53,40 & 58,84 & 86,48 & 7223 \\
\hline & Po Tota & $100,00 \%$ & $100.00 \%$ & $100,00 \%$ & $100.00 \%$ & $100,00 \%$ & 100,00 & & 100,00 & 100,00 & 100 \\
\hline \multirow{4}{*}{ Sto. Andre } & Agropecuaria & $0,10 \%$ & $0,03 \%$ & $0,02 \%$ & $0,01 \%$ & $0,00 \%$ & 0,00 & 0,00 & 0,00 & 0,00 & 0 \\
\hline & Indostria & $73,98 \%$ & $75,90 \%$ & $69,11 \%$ & $71,63 \%$ & $42,42 \%$ & 34.22 & 32.47 & 27.57 & 22,48 & 22,00 \\
\hline & Servpos & $25,92 \%$ & $24,07 \%$ & $30,88 \%$ & $28,36 \%$ & $57,58 \%$ & 65,77 & 67.52 & 72.26 & 77.51 & 77,9 \\
\hline & PO Total & $100,00 \%$ & $100.00 \%$ & $100,00 \%$ & $100,00 \%$ & $100,00 \%$ & 99.99 & & 99.83 & 99,99 & 90,90 \\
\hline & Agropecuaria & $0.00 \%$ & $0,01 \%$ & $0.00 \%$ & $0,01 \%$ & $0.00 \%$ & 0,00 & 0,00 & 0,00 & 0,00 & 0 \\
\hline sao caetano & Indostra & $54,89 \%$ & $76,17 \%$ & $71,50 \%$ & $66.55 \%$ & $48,01 \%$ & 45,94 & 50,01 & 35,11 & 30,49 & 27,06 \\
\hline & Servipos & $45,11 \%$ & $23,82 \%$ & $28.50 \%$ & $33.43 \%$ & $51,99 \%$ & 54,06 & 49.99 & 64,89 & 60.51 & 72,84 \\
\hline & Plo Tota & $100,00 \%$ & $100,00 \%$ & $100,00 \%$ & $100,00 \%$ & $100,00 \%$ & 100,00 & & 100,00 & 100,00 & 100 \\
\hline & Agropecuarla & $0.05 \%$ & $0,01 \%$ & $0.00 \%$ & $0,00 \%$ & $0.00 \%$ & 0,00 & 0,00 & 0,00 & 0,00 & 0,01 \\
\hline & indostra & $75,14 \%$ & $80,37 \%$ & $74,46 \%$ & $74,94 \%$ & $70,31 \%$ & 46,30 & 46,47 & 43.02 & 35.13 & 33.75 \\
\hline & Servpos & $24,80 \%$ & $19,62 \%$ & $25,54 \%$ & $25,05 \%$ & $29,69 \%$ & 53,70 & 53,53 & 56,97 & 64,87 & 60,25 \\
\hline & Plo Total & $100,00 \%$ & $100,00 \%$ & $100,00 \%$ & $100,00 \%$ & $100,00 \%$ & 100,00 & & 99,99 & 100,00 & 100.01 \\
\hline & Agropecuaria & $0,03 \%$ & $0,09 \%$ & $0,03 \%$ & $0,06 \%$ & $0,00 \%$ & 0,01 & 0,01 & 0,01 & 0.01 & 0,01 \\
\hline & Indostria & $82,05 \%$ & $52,89 \%$ & $58,16 \%$ & $79,80 \%$ & $73.80 \%$ & 45,95 & 47,54 & 39.96 & 32.8 & 38.38 \\
\hline & Serviços & $17,92 \%$ & $47,02 \%$ & $41,81 \%$ & $20,14 \%$ & $26.20 \%$ & 53,14 & 52,45 & 60.03 & 67,19 & 61,61 \\
\hline & PQ Tola & $100.00 \%$ & $100.00 \%$ & $100,00 \%$ & $100.00 \%$ & $100,00 \%$ & 100,10 & & 100,00 & 100,00 & 100 \\
\hline & Agropecuarta & $3.69 \%$ & $5,13 \%$ & $1,06 \%$ & $1,21 \%$ & $0,15 \%$ & 0,15 & 0,12 & 0,11 & 0.11 & 0,07 \\
\hline & Industria & $60,85 \%$ & $70,89 \%$ & $70,40 \%$ & $68.54 \%$ & $53,57 \%$ & 30,18 & 33,87 & 37,05 & 32,24 & 25.57 \\
\hline & Servipos & $35,45 \%$ & $23,98 \%$ & $28,54 \%$ & $30.25 \%$ & $46.28 \%$ & 69,28 & 66,01 & 62,83 & 66,86 & 74,38 \\
\hline & Po Tota & $100,00 \%$ & $100.00 \%$ & $100,00 \%$ & $100,00 \%$ & $100,00 \%$ & 99.61 & & 99.99 & 100,01 & 100 \\
\hline & Agropecuaria & $0,33 \%$ & $0.81 \%$ & $0,74 \%$ & $0,59 \%$ & $0,12 \%$ & 0.09 & 0,09 & 0,09 & 0.08 & 0.12 \\
\hline & Indostria & $62,75 \%$ & $71,65 \%$ & $70,01 \%$ & $68,37 \%$ & $45,75 \%$ & 32.71 & 32,04 & 28.91 & 25.55 & 31,28 \\
\hline & Serviços & $36,92 \%$ & $27,53 \%$ & $29.25 \%$ & $31,03 \%$ & $54,13 \%$ & 67.20 & 67,88 & 71,00 & 74.39 & 68.6 \\
\hline & PIO Tola & $100,00 \%$ & $100,00 \%$ & $100,00 \%$ & $100,00 \%$ & $100,00 \%$ & 100,00 & 100,01 & 100,00 & 100,00 & 100 \\
\hline & Agropecuaria & $0.02 \%$ & $0,04 \%$ & $0,02 \%$ & $0,02 \%$ & $0,00 \%$ & 0,01 & 0,00 & 0,00 & 0.01 & 0.01 \\
\hline LO & Industria & $46,78 \%$ & $51,83 \%$ & $44,34 \%$ & $45,14 \%$ & $35,14 \%$ & 17,42 & 15,30 & 15,47 & 12,97 & 11,86 \\
\hline & Servpos & $53,20 \%$ & $48,13 \%$ & $55,64 \%$ & $54,84 \%$ & $64,85 \%$ & 82.57 & 84,70 & 84,70 & 87,02 & 88,13 \\
\hline & Plo Tola & $100,00 \%$ & $100,00 \%$ & $100,00 \%$ & $100,00 \%$ & $100,00 \%$ & 100,00 & 100,00 & 100,17 & 100,00 & 100 \\
\hline
\end{tabular}

